
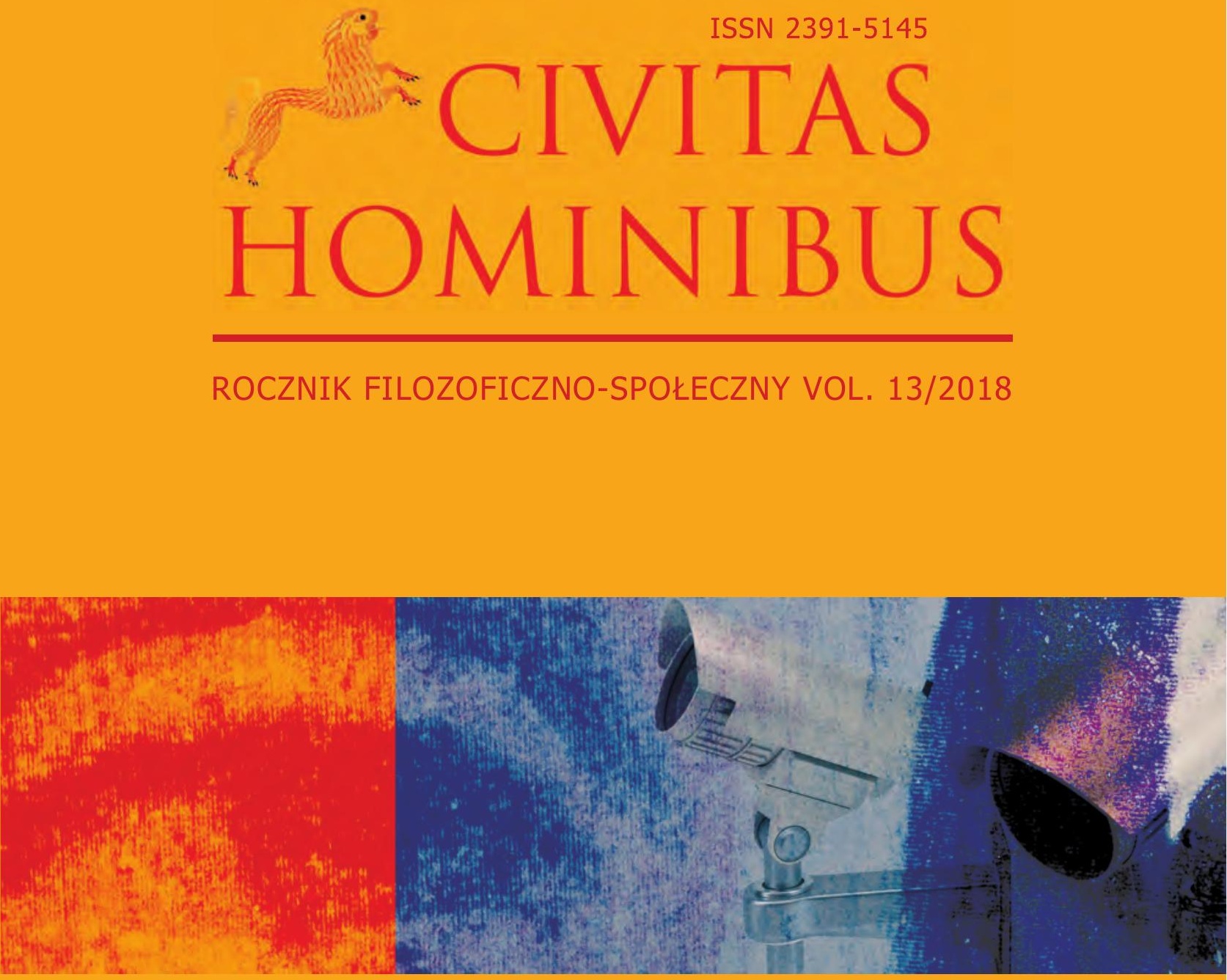


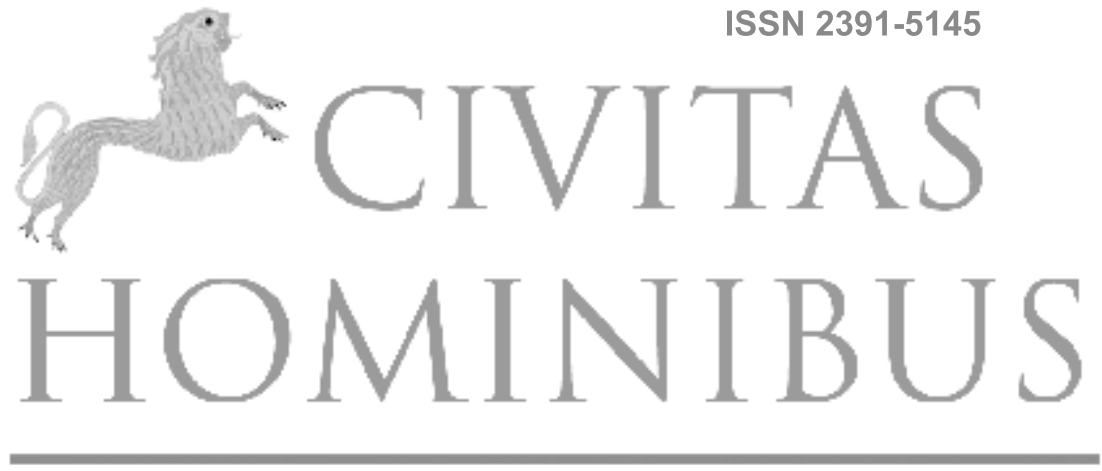

ROCZNIK FILOZOFICZNO-SPOŁECZNY VOL. 1(13)/2018 
Redaktor naczelny: prof. dr hab. Marek Malinowski (AHE)

Redakcja tematyczna: dr hab. Edyta Pietrzak (PŁ) (sekretarz), dr Łukasz Zaorski-Sikora (AHE)

Redakcja językowa: dr Ewa Gdak (AHE) - teksty polskojęzyczne mgr Marcin Jaźwiec (AHE) - teksty anglojęzyczne

\section{Rada programowa:}

Prof. dr hab. Andrzej Antoszewski (Uniwersytet Wrocławski)

Prof. dr hab. Roman Bäcker (Uniwersytet Mikołaja Kopernika w Toruniu)

dr hab. Tadeusz Dmochowski prof. UG (Uniwersytet Gdański)

Prof. Jeff Holdeman (Indiana University)

Prof. dr hab. Andrzej de Lazari (Uniwersytet Łódzki)

Prof. Tuomo Melasuo (University of Tampere)

Dr hab. Rafał Ożarowski prof. WSAiB (Wyższa Szkoła Administracji i Biznesu)

Prof. Pinar Melis Yelsali Parmaksiz (Bahcesehir University)

Prof. dr hab. Stanisław Parzymies (Akademia Finansów i Biznesu Vistula)

Prof. Elena Shlienkova (Samara State University of Architecture and Civil Engineering)

Prof. AHE, dr Makary Stasiak (Akademia Humanistyczno-Ekonomiczna w Lodzi)

Prof. Liisa Westman (University of Eastern Finland)

Prof. dr hab. Andrzej Wojtczak (Collegium Mazovia Innowacyjna Szkoła Wyższa)

Recenzenci spoza redakcji:

Dr hab. Piotr Bohdziewicz prof. UŁ (Uniwersytet Łódzki)

Dr hab. Tadeusz Dmochowski prof. UG (Uniwersytet Gdański)

Prof. dr hab. Bogusław Jagusiak (Wojskowa Akademia Techniczna)

Prof. dr hab. Elżbieta Jung (Uniwersytet Łódzki)

Dr hab. Krystyna Leszczyńska (Uniwersytet Marii Curie-Skłodowskiej w Lublinie)

Dr hab. Dominik Mierzejewski prof. UŁ (Uniwersytet Łódzki)

Dr hab. Joanna Mysona-Byrska prof. UPJPII (Uniwersytet Papieski Jana Pawła II w Krakowie)

Dr hab. Marek prof. UŁ Ostrowski (Uniwersytet Łódzki)

Dr hab. Rafał Ożarowski prof. WSAiB (Wyższa Szkoła Administracji i Biznesu)

Prof. dr hab. Stanisław Parzymies (Akademia Finansów i Biznesu Vistula)

Dr hab. Roman Pelczar prof. KUL (Katolicki Uniwersytet Lubelski)

Prof. dr hab. Agnieszka Rothert (Uniwersytet Warszawski)

Prof. dr hab. Grzegorz Sztabiński (Uniwersytet Łódzki)

Prof. dr hab. Janusz Świniarski (Wojskowa Akademia Techniczna)

Dr hab. Ireneusz Marian Świtała prof. UP (Uniwersytet Pedagogiczny w Krakowie)

Prof. dr hab. Grażyna Ulicka (Uniwersytet Warszawski)

Prof. dr hab. Arkadiusz Żukowski (Uniwersytet Warmińsko-Mazurski)

Dr hab. Helena Marzec prof. UJK (Uniwersytet Jana Kochanowskiego)

Dr Katarzyna Dośpiał-Borysiak (Uniwersytet Łódzki)

\section{Redakcja czasopisma „Civitas Hominibus”}

Akademia Humanistyczno-Ekonomiczna w Łodzi

90-212 Łódź, ul. Sterlinga 26

tel. 0-426315070

(C) Copyright by Akademia Humanistyczno-Ekonomiczna w Łodzi Łódź 2018

\section{ISSN 2391-5145}

wersja elektroniczna na podstawie wersji papierowej

Korekta: Iwona Cłapińska (PUW)

Skład DTP: Monika Poradecka

\section{Wydawnictwo Akademii Humanistyczno-Ekonomicznej w Lodzi}

90-212 Łódź, ul. Sterlinga 26

tel./fax 426315908

wydawnictwo@ahe.lodz.pl

www.wydawnictwo.ahe.lodz.pl 


\section{Spis treści}

ARTYKUŁY - DYSKUSJE - ESEJE

Marek J. Malinowski

Bezpieczeństwo we współczesnym świecie. Istota zjawiska

i jego uwarunkowania (refleksje osobiste)

Konrad Hennig

Bezpieczeństwo egzystencjalne społeczeństw Zachodu wobec współczesnego sporu epistemologicznego

Artur Niedźwiedzki

(Nie)Bezpieczna Europa po Brexicie?

Waldemar Mańkowski

Bezpieczeństwo biologiczne populacji. Zdrowie publiczne

a Państwowa Inspekcja Sanitarna jako najważniejsza instytucja

sfery zdrowia publicznego

Piotr Ogrodowczyk

„Środki aktywne” - skuteczne działania rosyjskich służb specjalnych.... 59

Agnieszka Stanecka

Veiling and unveiling fears in Leila Aboulela's Minaret .

$Ł u k a s z$ Zwoliński

Znaczenie logistyki w zarządzaniu kryzysowym

MISCELLANEA

Ilona Balcerczyk

Society in the theory of Karl Popper

Sabrina P. Ramet

Muzyka rockowa a polityka w Polsce: poetyka protestu i oporu w tekstach utworów rockowych 
Kamila Lasocińska

Kształtowanie twórczej codzienności. Warsztat autobiograficzny

jako metoda wspomagania kreatywności dorosłych

Mirosław Mielczarek

Przygotowanie do samodzielności życiowej usamodzielnianych

wychowanków placówek opiekuńczo-wychowawczych.

Elżbieta Woźnicka

Niesłyszący nauczyciel w systemie edukacji - szanse i ograniczenia

Łukasz Zaorski-Sikora

Kreatywna edukacja. Dobre praktyki

PRACE STUDENCKIE

Izabela Maruszewska

Znaczenie funkcji sołtysa we współczesnej Polsce

Adam Fik

Islamskie organizacje terrorystyczne na przykładzie Al-Kaidy

i Państwa Islamskiego.

Sebastian Szulc

Nacjonalizm w przeszłości i czasach obecnych w Europie 203

RECENZJE

Edyta Pietrzak

Aldona Wiktorska-Święcka, Monika Klimowicz,

Małgorzata Michalewska-Pawlak, Innowacje we współzarządzaniu

rozwojem regionalnym. Praktyka instytucjonalna $w$ wybranych

regionach w Polsce

Edyta Pietrzak

Inga B. Kuźma, Łucja Lange (red.), Mieszkanie i dom jako

nieoczywistość kulturowo-społeczna.

Edyta Pietrzak

Joanna Sośnicka (red.), Inżynier z duszą humanisty. 


\section{Table of Contents}

ARTICLES - DISCUSSIONS - ESSEYS

Marek J. Malinowski

Security in the contemporary world. The essence of the phenomenon

and its determinants (Personal reflections)

Konrad Hennig

The influence of contemporary epistemological disputes on the existential security of Western societies

Artur Niedźwiedzki

(Un)Secured Europe after Brexit?

Waldemar Mańkowski

Biological security of the population. Public health and the State Sanitary Inspectorate as the most important institution of the public health sphere

Piotr Ogrodowczyk

"Active measures" - effective operations of the Russian secret services

Agnieszka Stanecka

Veiling and unveiling fears in Leila Aboulela's Minaret

Łukasz Zwoliński

The meaning of logistics in crisis management

85 MISCELLANEA

Ilona Balcerczyk

Society in the theory of Karl Popper

Sabrina P. Ramet

Rock music and politics in Poland: The poetics of protest and resistance in the lyrics of rock songs 
Kamila Lasocińska

Shaping creative everyday life. An autobiographical workshop

as a method of supporting the creativity of adults

Mirosław Mielczarek

Preparation for independent living: Independent foster-child Care

and Educational Institutions.

Elżbieta Woźnicka

Deaf teachers in the education system - opportunities and limitations ... 169

Łukasz Zaorski-Sikora

Creative education. Good practices

STUDENTS' WORKS

Izabela Maruszewska

The importance of the village leader's function

in contemporary Poland.

Adam Fik

Islamic terrorist organisations based on the example of al-Qaeda

and the Islamic State.

Sebastian Szulc

Nationalism in the past and present in Europe.

REVIEWS

Edyta Pietrzak

Aldona Wiktorska-Święcka, Monika Klimowicz,

Małgorzata Michalewska-Pawlak, Innovation in co-management

of regional development. Institutional practice in selected regions

in Poland.

207

Edyta Pietrzak

Inga B. Kuźma, Łucja Lange (eds.), Housing and home as a cultural

and social unobviousness

Edyta Pietrzak

Joanna Sośnicka (ed.), Engineer with a humanist's soul. 


\section{Bezpieczeństwo we współczesnym świecie. Istota $z$ jawiska i jego uwarunkowania (refleks je osobiste)}

Oddając do rąk Czytelników kolejny 13 - szczęśliwa liczba dla redaktora naczelnego numer naszego Rocznika Filozoficzno-Społecznego „Civitas Hominibus” z 2018 roku, pragnę zauważyć, iż jego przewodnim przesłaniem jest stanowiące bez wątpienia jeden z najbardziej fundamentalnych problemów współczesnego świata zagadnienie szeroko pojętego bezpieczeństwa narodowego i międzynarodowego, które w drugiej dekadzie XXI wieku jest kwestią rozpatrywaną na trzech splecionych ze sobą integralnie płaszczyznach: globalnej, regionalnej i lokalnej. Problematyka bezpieczeństwa budzi wielkie zainteresowanie i emocje w XXI wieku, jakkolwiek jest „stara jak świat”, o czym wymownie świadczą wersety biblijnej Księgi Rodzaju odnoszące się do pierwotnego pojmowania bezpieczeństwa jako braku zagrożenia dla egzystencji człowieka w środowisku naturalnym i społecznym. Mamy tu na myśli trzy wydarzenia naruszające tak rozumiane bezpieczeństwo istot ludzkich - wypędzenie Adama i Ewy z raju, zabicie Abla przez Kaina oraz zbudowanie przez Noego arki wobec zagrożenia ludzkości potopem. Jak bowiem stwierdził w swej książce prof. gen. Stanisław Koziej, arka Noego była kluczowym elementem „systemu bezpieczeństwa wszystkich gatunków ludzkości”l.

Od najdawniejszych czasów istnienia ludzkiej cywilizacji pojęcie bezpieczeństwa zmieniało swój zakres, wymiary i formy, ale jego istota pozostawała niezmienna. Ewolucji ulegały zatem różne uwarunkowania tego zjawiska, natomiast jego sens i charakter stanowiły stałe „continuum” mijających wieków. Pojęcie bezpieczeństwa w naszym kręgu cywilizacyjnym pochodzi z czasów rzymskich, w których słowo se

${ }^{1}$ S. Koziej, Między piektem a rajem. Szare bezpieczeństwo na progu XXI wieku, Wydawnictwo Adam Marszałek, Toruń 2008, s. 16-17. 
cura oznaczało wolny od troski, a termin securitas identyfikowany był ze stabilnością polityczną ${ }^{2}$.

W czasach współczesnych istota tego zjawiska ma charakter zarówno subiektywny, jak i obiektywny. Polscy badacze uznający je za subiektywne podkreślają takie cechy, jak stan silnych emocji, strach i poczucie zagrożenia, kiedy ich brak oznacza w istocie przekonanie o bezpieczeństwie osobistym, natomiast inni spośród nich, oceniający to zjawisko w kategoriach obiektywnych, sądzą, że poczucie bezpieczeństwa oznacza brak jakichkolwiek wyraźnych zagrożeń dla istnienia ludzi i stworzonych przez nich instytucji życia publicznego ${ }^{3}$.

Próbując pogodzić te dwa odmienne stanowiska, Arnold Wolfers zauważył, iż bezpieczeństwo w znaczeniu obiektywnym oznacza stan braku zagrożeń dla istotnych wartości cywilizacyjnych, a w znaczeniu subiektywnym - stan braku obaw, że te wartości mogą być zagrożone ${ }^{4}$. Sekundował mu w tym rozumowaniu inny zachodni badacz Daniel Frei, który odnotował współistnienie obu punktów odniesienia wobec rozumienia zjawiska bezpieczeństwa, stwierdzając ze swej strony, iż bezpieczeństwo zawiera w sobie cztery odrębne stany: braku bezpieczeństwa, obsesji, fałszywego bezpieczeństwa i rzeczywistego bezpieczeństwa 5 .

W naszym przekonaniu najtrafniejszą definicję istoty bezpieczeństwa przedstawił prof. Ryszard Zięba z Uniwersytetu Warszawskiego, który podkreślił, że „,bezpieczeństwo można określić jako pewność istnienia i przetrwania, posiadania oraz funkcjonowania i rozwoju przedmiotu. Pewność jest wynikiem nie tylko braku zagrożeń [...] ale także powstaje wskutek kreatywnej działalności i jest zmienna w czasie, czyli ma naturę procesu społecznego"6.

Skoro zatem określiliśmy z dużym przybliżeniem istotę bezpieczeństwa, możemy podjąć teraz dyskurs na temat różnorodnych uwarunkowań tego o wiele bardziej złożonego niż się wydawało u schyłku XX wieku zjawiska społeczno-politycznego.

Mocno akcentujemy to spostrzeżenie, gdyż w okresie ,zimnej wojny”, tj. konfrontacji i rywalizacji wzajemnej kapitalistycznego Zachodu i socjalistycznego Wschodu, rozgrywającej się od końca lat 40. do przełomu lat 80. i 90. XX wieku, za pewien paradygmat w nauce o stosunkach międzynarodowych i naukach o polityce uznawano tezę, że bezpieczeństwo narodowe, a zwłaszcza międzynarodowe, dotyczy w zasadzie wyłącznie sfery militarnej. Było to o tyle słuszne, że w warunkach szaleńczego wyścigu zbrojeń nuklearnych z udziałem Stanów Zjednoczonych Ameryki (United States of America, USA) i Związku Socjalistycznych Republik Radzieckich (ZSRR) najważniejszym zagrożeniem dla tak pojętego bezpieczeństwa była możliwość globalnego starcia zbrojnego tych dwóch supermocarstw, której efektem mogłaby stać się zagłada ludzkiej cywilizacji.

2 J. Czaputowicz, Bezpieczeństwo międzynarodowe. Współczesne koncepcje, PWN, Warszawa 2012, s. 22.

3 M. Pietraś, K.A. Wojtaszczyk (red.), Polska w systemie bezpieczeństwa międzynarodowego, Oficyna Wydawnicza Aspra-Jr, Warszawa 2016, s. 20.

4 A. Wolfers, Discord and collaboration. Essays on International politics, The Johns Hopkins University Press, Baltimore 1962, s. 150.

5 D. Frei, Sicherheit. Grundwagen der Weltpolitik, Stuttgart 1977, s. 19-20.

${ }^{6}$ R. Zięba, Wprowadzenie. Pozimnowojenny paradygmat bezpieczeństwa międzynarodowego, [w:] tegoż (red.), Bezpieczeństwo międzynarodowe po zimnej wojnie, Wydawnictwa Akademickie i Profesjonalne, Warszawa 2008, s. 16. 
Obecnie jednak u schyłku drugiej dekady XXI wieku uwarunkowania zjawiska szeroko rozumianego bezpieczeństwa wykraczają daleko poza sferę militarną. Oczywiście nikt wśród badaczy współczesnej rzeczywistości międzynarodowej nie będzie twierdził, iż ta sfera przestała mieć zasadnicze znaczenie dla kształtowania się obrazu Nowego Ładu Międzynarodowego (New World Order, NWO), który formuje się w świecie od upadku ZSRR w 1991 roku. Wprawdzie amerykański uczony mąż Henry Kissinger sugerował w swym dziele z początku lat 90 . ubiegłego wieku, że w perspektywie XXI wieku czynnik militarny będzie systematycznie tracił swe znaczenie i oddziaływanie na stosunki międzynarodowe ${ }^{7}$, ale było to w naszym przeświadczeniu klasyczne wishful thinking, które okazało się w następnym okresie całkowicie fałszywe i bezzasadne.

Czynnik militarny odgrywa więc nadal niezmiernie istotną rolę w kwestii bezpieczeństwa, biorąc pod uwagę na przykład postępującą proliferację broni masowego zniszczenia (BMZ) wobec powiększenia się grupy państw dysponujących bronią nuklearną o Koreańską Republikę Ludowo-Demokratyczną (KRL-D) i Izrael oraz dążeń do jej uzyskania przez Iran, Brazylię i inne państwa Południa świata.

W XXI wieku rośnie liczba zbrojnych konfliktów na jego obszarach, m.in. pogłębia się konfrontacja izraelsko-palestyńska, toczą się nadal wojny domowe w Syrii i Jemenie oraz konflikt turecko-kurdyjski, do niedawna trwały walki zbrojne z Państwem Islamskim (Islamic State, IS - arabski akronim Daesz) w Syrii i Iraku, kontynuowana jest batalia militarna w Afganistanie będąca rezultatem niezakończonej dotąd zbrojnej interwencji USA w tym kraju - w XXI wieku dokonały one również nielegalnej z punktu widzenia prawa międzynarodowego agresji na rządzony przez prezydenta Saddama Husajna at-Takritiego Irak.

Ponadto burzliwie narasta ekspansja międzynarodowego terroryzmu, którego twarzą jest przede wszystkim radykalny fundamentalizm muzułmański. Stanowi on bez wątpienia jedno z najważniejszych zagrożeń dla bezpieczeństwa międzynarodowego u chyłku drugiej dekady XXI wieku, któremu Zachód nie potrafi - jak dotąd - skutecznie i efektywnie się przeciwstawić.

Z kolei na terenie „starej” Europy obserwujemy coraz bardziej widoczną agresywną postawę Federacji Rosyjskiej, której prezydent Władimir Władimirowicz Putin podjął trud odbudowy jej mocarstwowej pozycji we współczesnym świecie. W XXI wieku Rosja znacznie przyspieszyła proces modernizacji i rozbudowy swych sił zbrojnych, w tym przede wszystkim nuklearnych, oraz wdała się w zwycięską wojnę z Gruzją, a następnie włączyła do swego terytorium Krym i rozpoczęła zbrojną interwencję w wojnę domową na Ukrainie, protegując prorosyjskich separatystów w Donbasie we wschodniej części kraju ${ }^{8}$.

Drugim - po militarnym - czynnikiem warunkującym bezpieczeństwo narodowe i międzynarodowe są przemiany społeczno-polityczne i ekonomiczne zarówno w naszym kręgu cywilizacyjnym, jak i w świecie muzułmańskim oraz innych regionach Południa świata, ze szczególnym uwzględnieniem Chińskiej Republiki Ludowej (ChRL) i Indii. Na pierw-

\footnotetext{
7 Zob. H. Kissinger, Dyplomacja, Philip Wilson, Warszawa 1998, passim.

8 Zob. S. Bieleń, Tożsamość międzynarodowa Federacji Rosyjskiej, Oficyna Wydawnicza Aspra-Jr, Warszawa 2006, passim i J. Zając, A. Włodkowska-Bagan, M. Kaczmarski (red.), Bezpieczeństwo międzynarodowe: Polska - Europa - Świat, Wydział Dziennikarstwa i Nauk Politycznych. Uniwersytet Warszawski, Warszawa 2015, passim.
} 
szy plan wysuwają się tu dwa powiązane ze sobą merytorycznie i mające doniosłe znaczenie zjawiska: kryzys liberalnej demokracji typu amerykańsko-zachodnioeuropejskiego oraz coraz gwałtowniejszy przypływ populizmu i skrajnych poglądów o charakterze nacjonalistycznym, rasistowskim, neofaszystowskim i homofobicznym w naszym kręgu cywilizacyjnym oraz radykalizmu religijno-politycznego w świecie islamu.

Istotne znaczenie mają także w tym kontekście geopolitycznym nasilające się tendencje hegemonistyczne i imperialistyczne w polityce zagranicznej USA, które zapoczątkował prezydent George W. Bush, kontynuował mimo zaprzeczeń Barrack Obama, a najpełniejszy ich wyraz prezentuje obecny gospodarz Białego Domu Donald Trump. Od momentu objęcia stanowiska prezydenta USA zaskakuje on, a nawet szokuje sojuszników i światową opinię publiczną swymi wypowiedziami i praktycznymi posunięciami w sferze stosunków międzynarodowych, czego wymownymi przykładami są jego spotkania z przywódcą KRL-D Kim Dzong Unem w czerwcu 2018 roku w Singapurze i prezydentem Rosji W. Putinem w lipcu tego samego roku w Helsinkach, które wzbudziły wiele kontrowersji we współczesnym świecie.

Kolejnym niezmiernie ważnym elementem współczesnych przemian społeczno-politycznych i ekonomicznych jest rozszerzająca się z każdym rokiem globalizacja, która obejmuje wszystkie regiony świata, włącznie ze, zdawałoby się, całkowicie peryferyjnymi obszarami geopolitycznymi w rodzaju archipelagów wysp w Oceanii czy też na przykład wiejskich terenów państw Czarnej Afryki. Przemawia do nas refleksja, że uczestnikami procesów globalizacyjnych u schyłku drugiej dekady XXI wieku są też nasze siostry i bracia z tzw. zapadłych rejonów planety, którzy nigdy nie słyszeli o tym zjawisku.

Z punktu widzenia problematyki bezpieczeństwa narodowego i międzynarodowego na szczególną uwagę zasługuje taka znamienna konsekwencja globalizacji,jak na przykład coraz bardziej dramatyczne rozwarstwienie współczesnego świata. Obserwujemy z jednej strony bogacącą się ekonomicznie elitę najbardziej rozwiniętych państw Zachodu i malejącą liczbowo mniejszość ich społeczeństw, a także część arabskich krajów naftowych i górne warstwy ich obywateli, z drugiej natomiast - wzrastającą lawinowo liczebnie biedną czy wręcz nędzną, przytłaczającą większość ludności krajów Południa świata, które postępują po drodze tzw. cywilizacyjnego rozwoju w niezbyt szybkim tempie. Oznacza to, że dystans pomiędzy krajami Południa i Północy świata nie tylko nie maleje, lecz wręcz odwrotnie - powiększa się w widoczny sposób.

Innym skutkiem procesów globalizacyjnych z omawianego punktu widzenia jest dynamicznie narastający opór i sprzeciw znaczącej i wpływowej części społeczeństw Południa świata, w tym zwłaszcza krajów muzułmańskich, wobec narzucanych im zachodnich, głównie amerykańskich, wzorców wartości, etyki i moralności, postępowania, szeroko rozumianej kultury codziennej, a nawet upodobań rozrywkowych i kulinarnych - mamy tu na myśli specyficzny model „macdonaldyzacji” świata - co jest dla nich absolutnie niemożliwe do przyjęcia i wdrażania w życie.

Pisał o tym - jako istotnym elemencie zbliżającej się konfrontacji cywilizacyjnej pomiędzy światem Zachodu, a światem islamu - już u schyłku lat 90. XX wieku w swej książce amerykański badacz Benjamin Barber . Jak można sądzić, dziś po upływie dwudziestu lat te stwierdzenia są w pełni nadal aktualne.

\footnotetext{
9 Zob. B. Barber, Dżihad kontra McŚwiat, „Muza”, Warszawa 1997, passim.
} 
Analizując inne ekonomiczne aspekty prezentowanych przemian we współczesnym świecie, należy również odnotować dalsze i szybkie postępy rozwojowe w pierwszej i drugiej dekadzie XXI wieku ChRL i Indii, które zmierzają w kierunku przekształcenia się w perspektywie obecnego stulecia w mocarstwa nie tylko regionalne, lecz także globalne, rzucające wyzwania polityczne, gospodarcze i cywilizacyjne, może nawet militarne, dominującym dotąd USA. Nie bez znaczenia jest również element demograficzny wyrażający się w przewidywaniach czołowych przedstawicieli tej dyscypliny naukowej, iż około połowy XXI wieku ponad 50\% ludzkości będzie zamieszkiwać tylko te dwa państwa. Gdyby te prognozy się sprawdziły, kształt rzeczywistości międzynarodowej za trzydzieści lat byłby zupełnie różny od obecnego i wieszczyłby koniec hegemonii USA i „Pax Americana” we współczesnym świecie.

Uwarunkowania bezpieczeństwa narodowego i międzynarodowego u schyłku drugiej dekady XXI wieku poza wskazanymi czynnikami militarnymi, społeczno-politycznymi i ekonomicznymi obejmują również przesłanki technologiczne, edukacyjne, ekologiczne i psychologiczne. Takie właśnie szeroko pojęte rozumienie tego wielowarstwowego zjawiska jest zgodne z obecnymi poglądami większości specjalistów w zakresie nauki o stosunkach międzynarodowych i nauk o polityce.

A oto kilka spostrzeżeń na ten temat. Na przykład oszałamiający - jak się wydaje postęp technologiczny dotykający poziomu przeciętnego mieszkańca planety (choć w niezwykle zróżnicowany sposób) spowodował nieprzewidywaną wcześniej coraz powszechniejszą alienację większości ludzi, którzy nie rozumieją szczegółów działania wyrafinowanych urządzeń i mechanizmów (posługują się nimi w życiu codziennym), ucząc się jedynie, jak wtórni analfabeci, kilku podstawowych czynności związanych z ich obsługą. Stan ten obniża społeczne i jednostkowe poczucie bezpieczeństwa osobistego, bez wątpienia odgrywając negatywną rolę w funkcjonowaniu obecnego społeczeństwa.

Z kolei wielki wzrost liczbowy osób uzyskujących wykształcenie średnie i wyższe (licencjackie, magisterskie) przyniósł równie nieoczekiwanie efekty negatywne w postaci szybko spadającego ich prestiżu społecznego i rosnących trudności w zdobyciu odpowiednio satysfakcjonującego zatrudnienia na rynku pracy, poddanym w naszym kręgu cywilizacyjnym zaczerpniętym z USA brutalnym regułom „wyścigu szczurów”. Stanowi to rezultat obniżającego się poziomu usług dydaktycznych, oferowanych przez szkoły średnie i wyższe uczelnie, w rezultacie ich komercjalizacji i ograniczania autonomii przez władze różnych szczebli, spadku jakości kształcenia mimo szerokiego propagowania metod projektowych (mają one w dużym stopniu fikcyjny i pozoracyjny charakter), spadających profesjonalnych kwalifikacji kadry nauczycielskiej przy równoczesnym coraz gorszym przygotowaniu intelektualnym edukującej się na poziomie podstawowym i średnim współczesnej młodzieży.

$\mathrm{Na}$ forum uniwersyteckim obserwujemy na przykład, że z każdą dekadą XXI wieku większość studentów reprezentuje coraz niższy poziom umysłowy, nie mówiąc już o posiadanej wiedzy ogólnej i rozeznaniu w zawiłych meandrach współczesnego świata. Stan ten w zakresie poczucia bezpieczeństwa osobistego jest analogiczny, jak w przypadku omawianego poprzednio czynnika technologicznego. 
Ekologiczne przesłanki analizowanego bezpieczeństwa związane są z postępującą dewastacją środowiska naturalnego na naszej planecie, której tempo narasta od początku XXI wieku mimo coraz głośniejszych ostrzeżeń ze strony specjalistów przedmiotu oraz aktywizacji różnych organizacji i stowarzyszeń obywatelskich. Bezwzględne zasady rynkowej komercjalizacji i pogoni za maksymalizacją szybkich zysków w ramach procesów globalizacyjnych sprawiają, że ogólny stan bezpieczeństwa także i w tym zakresie odpowiada powyższym stwierdzeniom.

Wszystkie scharakteryzowane pokrótce uwarunkowania bezpieczeństwa we współczesnym świecie łączą się integralnie z ostatnimi przesłankami tego zjawiska, tj. z elementami psychologicznymi, rozpatrywanymi zarówno na poziomie pojedynczego „homo sapiens”, jak i na poziomie światowych elit władzy politycznej, ekonomicznej i militarnej. Tworzą one bowiem ramy kształtowania się zjawiska bezpieczeństwa narodowego i międzynarodowego we współczesnym świecie.

Sumując dotychczasowe rozważania, pragnąłbym wyrazić, jak zawsze, nadzieję, że kolejny numer 13 „Civitas Hominibus” będzie pobudzającym intelektualnie wkładem do szerokiej dyskusji i indywidualnych przemyśleń naszych Czytelników na temat istoty i uwarunkowań zjawiska bezpieczeństwa u schyłku drugiej dekady XXI wieku.

\section{Bibliografia}

Barber B., Dżihad kontra McŚwiat, „Muza”, Warszawa 1997.

Bieleń S., Tożsamość międzynarodowa Federacji Rosyjskiej, Oficyna Wydawnicza Aspra-Jr, Warszawa 2006.

Czaputowicz J., Bezpieczeństwo międzynarodowe. Współczesne koncepcje, PWN, Warszawa 2012.

Frei D., Sicherheit. Grundwagen der Weltpolitik, Stuttgart 1977.

Kissinger H., Dyplomacja, Philip Wilson, Warszawa 1998.

Koziej S., Między piekłem a rajem. Szare bezpieczeństwo na progu XXI wieku, Wydawnictwo Adam Marszałek, Torun 2008.

Pietraś M., Wojtaszczyk K.A. (red.), Polska w systemie bezpieczeństwa międzynarodowego, Oficyna Wydawnicza Aspra-Jr, Warszawa 2016.

Wolfers A., Discord and collaboration. Essays on International politics, The Johns Hopkins University Press, Baltimore 1962.

Zając J., Włodkowska-Bagan A., Kaczmarski M. (red.), Bezpieczeństwo międzynarodowe: Polska - Europa - Świat, Wydział Dziennikarstwa i Nauk Politycznych. Uniwersytet Warszawski, Warszawa 2015.

Zięba R., Wprowadzenie. Pozimnowojenny paradygmat bezpieczeństwa międzynarodowego, [w:] tegoż (red.), Bezpieczeństwo międzynarodowe po zimnej wojnie, Wydawnictwa Akademickie i Profesjonalne, Warszawa 2008. 


\section{Streszczenie \\ Bezpieczeństwo we współczesnym świecie. Istota zjawiska i jego uwarunkowania (Refleks je osobiste)}

Problematyka bezpieczeństwa podejmowana $\mathrm{w}$ artykule stanowi bez wątpienia jeden z najbardziej fundamentalnych problemów współczesnego świata. Zagadnienie szeroko pojętego bezpieczeństwa narodowego i międzynarodowego w drugiej dekadzie XXI wieku jest kwestią rozpatrywaną na trzech splecionych ze sobą płaszczyznach: globalnej, regionalnej i lokalnej. Polityczne, gospodarcze i ekologiczne uwarunkowania bezpieczeństwa łączą się integralnie z elementami psychologicznymi, analizowanymi zarówno na poziomie pojedynczego homo sapiens, jak i na poziomie światowych elit władzy politycznej, ekonomicznej i militarnej. Tworzą one bowiem ramy kształtowania się zjawiska bezpieczeństwa narodowego i międzynarodowego we współczesnym świecie.

Słowa kluczowe: bezpieczeństwo, wymiar lokalny, regionalny, globalny

\section{Summary \\ Security in the contemporary world. The essence of the phenomenon and its determinants (Personal reflections)}

The issue of security explored in the article is undoubtedly one of the most fundamental problems of the modern world. This article considers the issue of broadly understood national and international security, which in the second decade of the 21 st century is an issue considered on three integrally linked planes: global, regional and local. Political, economic and ecological conditions of security are integrally connected with psychological elements, considered both at the level of "homo sapiens", as well as at the level of the world's political, economic and military elites. They create a framework for shaping national and international security in the contemporary world.

Keywords: security, local, regional and global dimension 
Konrad Hennig (iD https://orcid.org/0000-0002-6100-8984 Akademia Humanistyczno-Ekonomiczna w Łodzi

\section{Bezpieczeństwo egzystencjalne społeczeństw Zachodu wobec współczesnego sporu epistemologicznego}

Piłat: „Co to jest prawda?” (J 18, 38)

Co to jest prawda? Jakie są jej prawomocne źródła? Odpowiedzi na te pytania stanowią epistemologiczne podstawy trwałości ludzkich zrzeszeń. Cywilizacje, czyli sposoby, w jakie organizujemy nasze życie społeczne, opierają się na powszechnie podzielanym światopoglądzie, a więc wspólnym postrzeganiu świata, czasu, człowieka oraz wspólnie wyznawanych wartościach i celach. Każdy przekaz cywilizacyjny posiada swoje źródła w narracji mitologicznej, religijnej bądź filozoficznej, które wyznaczają rozumienie każdej z powyższych pięciu części składowych. O trwałości i spoistości danej cywilizacji przesądza siła zaufania, jakie ludzie pokładają w prawdziwości tych fundamentów. Dla trwania cywilizacji kluczowa jest więc pozycja prawdy rozumianej jako „twierdzenie o rzeczywistości”.

Praktyka historyczna zdaje się dowodzić, że im silniejszy jest transcendentny charakter źródeł przekazu cywilizacyjnego, tym większą stabilność światopoglądu i, co za tym idzie, nienaruszalność ładu społecznego jest w stanie zapewnić. Konstatacja tego faktu doprowadziła Mikołaja Bierdiajewa do przekonania, że o żywotności danej cywilizacji świadczy jej religijność - jak również, że ratunek przed upadkiem cywilizacji mieści się wyłącznie w odrodzeniu religijnym ${ }^{1}$. W konsekwencji możemy wywodzić, że każda cywilizacja kwestionująca swoje podstawy, a więc atakująca religię, oddala się od swoich

\footnotetext{
${ }^{1}$ M. Bierdiajew, Nowe średniowiecze. Los czlowieka we wspótczesnym świecie, Fundacja „Aletheia”, Warszawa 2003, s. 14 i nast.
} 
źródeł i podąża ku śmierci². Czy taki los może czekać niebawem również cywilizację Zachodu, w którą silnie wpisana jest skłonność do podważania podstaw własnego istnienia?

Odmienne, konkurencyjne koncepcje prawdy w ramach jednego zrzeszenia cywilizacyjnego rodzą spory poprzedzające zazwyczaj przemiany cywilizacyjne. W niniejszym szkicu zamierzam przyjrzeć się dwóm konfliktom: na przełomie antyku i średniowiecza pomiędzy prawdą filozoficzną a objawioną oraz u progu nowożytności między prawdą objawioną a rozumową. Na tle tych konfliktów zobrazuję kategorię bezpieczeństwa egzystencjalnego, czyli pewności bytu i rozwoju własnej tożsamości, światopoglądu i sposobu życia. Zagrożeniami bezpieczeństwa egzystencjalnego, w zaproponowanym przez autora znaczeniu, są próby podważenia podstawowych przekonań i ugruntowanych zwyczajów wypływających z przekazu cywilizacyjnego kształtującego tożsamości jednostek.

Cywilizacja antyczna opierała się na mądrości naturalnej: filozoficznej koncepcji prawdy jako zgodności sądu z rzeczywistością. Mądrość grecka kształtowała się w kontrze do magicznych i pogańskich przesądów, które zdominowały i ukształtowały kształt wyobrażeń zbiorowych Orientu. Na bazie unikalnego tworu duchowego, który nazwali filozofią, Grecy wytworzyli odrębną cywilizację wraz ze swoistym stosunkiem do otaczającego świata i wobec drugiego człowieka ${ }^{3}$. Poświęcili swoją aktywność intelektualną badaniom spraw naturalnych: przyrodniczych i ludzkich. Ale horyzontem, jaki sobie wyznaczyli, była perspektywa wykraczająca poza doczesność: doskonałość świata idei, zasady harmonii i porządku. W filozofii antycznej „najwyraźniej uwidacznia się ta cecha, która stanowi o istocie greckiej sztuki i greckiego myślenia: zdolność jasnego dostrzegania niezmiennego ładu, który leży u podłoża wszystkiego, co się dzieje i co się zmienia w przyrodzie i w świecie ludzkim. Wszystkie ludy wydały jakieś prawodawstwa, ale tylko Grek szuka niestrudzenie takiego «prawa», które tkwi w istocie rzeczy - i stara się wedle niego kierować w swoim życiu i myśleniu"4.

Na gruncie filozoficznej mentalności Greków powstawały różne systemy polityczne: demokratyczne zrzeszenia polis, które zostały następnie podbite przez Imperium Rzymskie balansujące pomiędzy formami republikańskimi a wojskową monarchią, które z kolei rozpadło się na sukcesyjne królestwa barbarzyńskie, przejmujące model germańskich więzi społecznych. Ludy barbaricum były nie tylko potencjałem demograficznym, lecz ukształtowały tworzone na gruzach Imperium państwa europejskie. Państwa sukcesyjne miały charakter patrymonialny, ziemia i władza pozostawały własnością monarchów ${ }^{5}$. Władza, podzielona na wiele szczebli w hierarchii społecznej, wywodziła się z prawa własności. Pozycja każdej osoby, a także stanu społecznego uzależniona była od posiadanego majątku i sprawności w jego zabezpieczaniu. Prerogatywy uzyskiwane wraz z ojcowizną znajdowały poparcie w prawie zwyczaju, ale siła oręża była zawsze pierwszą i najważniejszą obroną własnych pretensji. W średniowieczu zanikły wysublimowane, antyczne

\footnotetext{
2 J. Sobczak, Zmierzch cywilizacji, Wydawnictwo Naukowe INPiD UAM, Poznań 2002, s. 27.

3 E. Husserl, Kryzys europejskiego człowieczeństwa a filozofia, Fundacja „Aletheia”, Warszawa 1993, s. 19.

${ }^{4}$ W. Jaeger, Paideia, Fundacja „Aletheia”, Warszawa 2001, s. 36.

5 L. Leciejewicz, Nowa postać świata. Narodziny średniowiecznej cywilizacji europejskiej, Wydawnictwo Uniwersytetu Wrocławskiego, Wrocław 2007, s. 438-439.
} 
metody uprawiania polityki, które przetrwały w Bizancjum: rozbudowana biurokracja, wywiad, system finansowy, dyplomacja i etykieta dworu ${ }^{6}$.

Organizacja polityczna, system władzy pozostały w państwach sukcesyjnych czysto barbarzyńskie. Ustrój rzymski, zarówno polityczny, gospodarczy, jak i społeczny, był zbyt skomplikowany, aby mógł zostać przyjęty przez najeźdźców ${ }^{7}$. W nowo ukształtowanych ustrojach monarchicznych nie istniało pojęcie obywatelstwa i ojczyzny, naród polityczny ograniczony był do wąskiego grona elit szlacheckich i duchownych. Nawet one nie wytworzyły idei patriotyzmu. Abstrakcyjna idea państwa niezwiązanego z osobą króla była niedostępna germańskiej wyobraźni. Feudalne zwierzchnictwo miało charakter osobisty, odnosiło się do konkretnego władcy lub arystokraty, zupełnie jak za czasów plemiennych. „Porządek społeczny tego okresu dziejowego nie narodził się w Rzymie. Ściśle biorąc, nie zawdzięcza też swego początku chrystianizmowi. Kościół - począwszy od czasów karolińskich - uznał go, przerobił w niektórych szczegółach, bardziej jeszcze wzmocnił i w pewnej mierze przeniósł na wyższy poziom, bo oparł na podstawie nadprzyrodzonej. Ale nie Kościół jest jego twórcą. W istocie swej porządek ten jest pochodzenia germańskiego".

Chrześcijaństwo w świat antycznej poezji, filozofii i mitologii wniosło z kolei emocjonalność szału krzyża, która przekreślała wartość dotychczasowego dorobku kultury. Przywróciła mądrość religijną, lecz nie była to, jak w kulturze Orientu, mądrość magiczna, lecz objawiona, udzielona człowiekowi przez Boga wraz z łaską świętości i zbawienia. Chrześcijańska ekonomia zbawienia niosła porządek i nadzieję społeczeństwom, które wyczerpały zasób własnych sił duchowych. Kosmologia oparta na panteizmie, wiecznym cyklu narodzin, śmierci i odrodzenia utrudniała poszukiwanie stałych reguł rządzących światem. Ludom przedchrześcijańskim świat jawił się jako chaos, który przezwyciężyć mogły tylko rytuały odkupienia i przebłagania bóstw - personifikowanych sił przyrody (burzy, sztormu, słońca czy księżyca) ${ }^{9}$. W fatalistycznym klimacie opinii panującym u schyłku starożytności religia chrześcijańska dostarczała potężnego oparcia, głosząc podporządkowanie dziejów wszechświata woli bożej, tłumacząc sens życia człowieka i obiecując życie wieczne po śmierci. ,Jedynie dzięki doświadczeniu, które jest kluczowym elementem w metodzie naukowej, możemy poznać wszechświat stworzony przez Boga. Możemy go również poznać dzięki temu, że jest on racjonalny, przewidywalny i zrozumiały"10. Takim, jakim uczynił go Bóg dla utwierdzenia i upewnienia naszego miejsca we wszechświecie, kładąc kres lękom i niepewności wobec rewolucyjnej rekonstrukcji naszego miejsca w świecie.

Wokół kultu religijnego rozwinęły się liczne rytualne sposoby budowania poczucia bezpieczeństwa. Wśród nich największą popularność zyskały procesje, relikwie, opieka

${ }^{6}$ J. Baszkiewicz, Myśl polityczna wieków średnich, Wydawnictwo Poznańskie, Poznań 1998, s. 25.

7 L. Genicot, Powstaje nowy świat. Studium o kulturze i cywilizacji wieków średnich, „Pax”, Warszawa 1964, s. 26.

8 Tamże, s. 30.

9 T. Woods, Jak Kościół katolicki zbudował zachodnią cywilizację, Wydawnictwo AA, Kraków 2006, s. $86-88$.

10 Tamże, s. 89. 
świętych, Maryi i anioła stróża, św. Józef jako patron dobrej śmierci, błogosławieństwa zapobiegawcze, modlitwy i obrzędy, odpusty, fetysze ochronne: ryngraf, szkalpierz i różaniec. Porzucono jednocześnie antyczne przywiązanie do wróżb, przepowiedni i proroków. Sojusz tronu i ołtarza, uniwersalistyczna misja monarchii pozwalały wprowadzić przewidywalność w wewnątrz- i międzypaństwowych stosunkach politycznych.

Oparcie ładu społecznego na objawionej przez Boga prawdzie ogniskowało większość kulturowych aktywności człowieka wokół spraw religijnych. „Celem ostatecznym życia ludzkiego - nie tylko jako najwyższa wartość dobra samego w sobie i dla siebie, lecz jako najwyższy przedmiot, którego posiadanie daje człowiekowi szczęście - jest sam Bóg, nieskończone Dobro, Byt istniejący sam przez się. Życie w Bogu, przedwieczna Chwała jest kresem, w którym nasze pragnienie szczęścia zostanie zaspokojone ponad miarę"11. Objawiona mądrość zawierała etykę nadaną człowiekowi przez Boga, przez co porządek moralny społeczeństwa miał znamiona trwałości i niepodważalności. Wierzono, że życie chrześcijanina przebiegało według boskiego scenariusza i reżyserii. Uciekano się pod opiekę anioła stróża, świętych i samej Opatrzności. Rozwijały się narracje prowidencjalizmu, wykoślawione później w kaliwinizmie w koncepcję predestynacji duszy.

Społeczeństwa Ancien regime żywiły ,przekonanie o bezwyjątkowej słuszności każdego rozwiązania w znanym stylu życia" "12, co było niewątpliwie przyczyną ich wielkiej trwałości. Ponadto potrafiły usuwać te nowości, które były niezgodne z ich tożsamością i zagrażały trwałości wspólnoty. Wiedza o świecie, a za nią kategorie życia społecznego przyjmowane były z wiarą rodzącą niezwykle emocjonalny do nich stosunek, dzięki czemu budowane były bardzo silne związki sensu - zrozumienie i akceptacja wszystkich zjawisk i wydarzeń. Tertuliańskie wyznanie credo quod absurdum symbolizowało siłę i zaufanie do prawdy objawienia.

Średniowiecze nie znało zwątpienia w Bożą Łaskę i objawioną naukę Chrystusa, które były źródłem prawdy o świecie. ,Wiedziało ono, że wielkie dzieło konstruktywne było tylko maską niewidzialnej tajemnicy miłości i pokory. [...] Chrześcijaństwo średniowieczne wiedziało praktycznie, że Słowo wstąpiło w ciało i że Duch Święty postępuje za tym ruchem i zstępuje tam także"13. Hierarchia mądrości sytuowała mądrość objawioną ponad mądrością człowieka. Wierzono, że zdobywanie mądrości zostało uprzednio umożliwione przez zstąpienie Syna Bożego, ofiarowanie miłości, mądrości i łaski. „I to nie człowiek zdobywa tę mądrość zbawienia, tę mądrość świętości, ale to Bóg, który mu ją daje. Nie wypływa to z momentu wzniesienia się istoty ludzkiej, a przeciwnie z momentu spłynięcia Ducha twórczego, z którego ta mądrość istotnie pochodzi"14.

Prawdę postrzegano jako depozyt otrzymany od Boga, którego treść jest wieczna i zawsze taka sama. Wiara w nienaruszalne podstawy światopoglądu i ładu społecznego była najpewniejszym źródłem bezpieczeństwa wobec niepewnej sytuacji egzystencjalnej: cyklicznych klęsk nieurodzaju, głodu, wojen i niepokojów, epidemii i chorób. Wobec trud-

\footnotetext{
11 J. Maritain, Pisma filozoficzne, Znak, Kraków 1988, s. 225.

12 M. Mead, Kultura i tożsamość: studium dystansu międzypokoleniowego, PWN, Warszawa 2000, s. 49.

13 J. Maritain, Nauka i mądrość, Fronda, Apostolicum, Warszawa-Ząbki 2005, s. 37.

14 Tamże, s. 31-32.
} 
ności bytowych niebagatelnej roli nabierała siła oczekiwań soteriologicznych. Burzliwy okres wędrówek ludów, zburzenie dawnego świata opartego na Pax Romana pchnął ludzi ku oczekiwaniom eschatologicznym, millenarystycznym i mistycznym. Poziom zaangażowania religijnego, jaki wywołał okres niepokojów wczesnego średniowiecza nie miał sobie równych w późniejszych wiekach. Był też w dużej mierze wynikiem wcześniejszych, dominujących od II do IV wieku nastrojów pesymizmu w całym świecie antyku. Ulegali mu niektórzy chrześcijanie (Ojcowie Pustyni), jak również gnostycy, odrzucający splamioną grzechem doczesność. Kościół, kształtując mentalność i duchowość rodzącej się cywilizacji, wchłaniał również podobne tendencje, lecz zamiast im ulegać, przełamywał zawartego w nich ducha fatalizmu.

Chrystus: ,Jam jest droga, i prawda” (J 14, 6).

Uniwersalistyczna misja chrześcijaństwa polegała na budowaniu jedności myśli i światopoglądu. Chrześcijaństwo spajało różnorodne czynniki wchodzące w skład cywilizacji łacińskiej. Duchowni stanowili trzon kadr średniowiecznych monarchii. „Rząd całego cesarstwa [karolińskiego - przyp. autora] był w znacznej mierze złożony z ludzi Kościoła, biskup bowiem dzielił z hrabią lokalną administrację w każdym z trzystu hrabstw, na które było podzielone cesarstwo, podczas gdy władzę centralną sprawowali głównie duchowni zarządzający kancelarią i kaplicą królewską; archikapelan był głównym królewskim doradcą i jednym z najwyższych dygnitarzy cesarstwa. Kontrolę i kierownictwo lokalnej administracji zapewniały typowo karolińskie instytucje tak zwanych missi dominici, którzy objeżdżali hrabstwa cesarstwa, podobnie jak angielscy sędziowie, i tu również najważniejsze misje powierzano biskupom i opatom"15. Duchowni administratorzy państwa karolińskiego odegrali decydującą rolę w tworzeniu jedności średniowiecznej Europy, ,podczas gdy hrabiowie i magnaci świeccy reprezentowali w większości interesy lokalne i terytorialne, przywódcy zaś grupy kościelnej ideał uniwersalnego cesarstwa, urzeczywistniającego jedność chrześcijańską i broniącego wiary"16.

Jacques Maritain rekonstruował średniowieczną myśl polityczną jako ideał Świętego Imperium. Jego cechami było dążenie do jedności organicznej (a więc harmonijnie spajającej zupełnie różne elementy), którego najbardziej spektakularnym tworem była wspólnota kulturowa całej chrześcijańskiej Europy; podrzędna i usługowa funkcja czynników materialnych i doczesnych wobec czynników duchowych, jak również wykorzystanie środków politycznych (zarówno przymusu fizycznego, prawodawstwa, nacisku opinii) dla dobra duchowego ludzi; patriarchalizm stosunków władzy i stosunków społecznych (hierarchia społeczna wyrażona w społeczeństwie stanowym i feudalnym); ostatnim rysem średniowiecza było oddanie religii (a zatem Chrystusowi za pośrednictwem Kościoła) roli przewodniej w kształtowaniu ustroju społeczno-politycznego ${ }^{17}$. Wśród pozytywnych

\footnotetext{
15 C. Dawson, Tworzenie się Europy, „Pax”, Warszawa 2000, s. 220.

16 Tamże, s. 255.

17 J. Maritain, O nową cywilizację chrześcijańską, Towarzystwo Wiedzy Chrześcijańskiej, Lublin 1935, s. 21-28.
} 
konsekwencji silnego Kościoła nawet nieprzychylny katolicyzmowi Edward Gibbon wymienił tendencje unifikujące państwo - wymianę informacji między kapłanami i zakonami z różnych prowincji, zjednoczeniową duchową jedność wszystkich chrześcijan ${ }^{18}$. Fundamentem położonym pod ówczesnym zjednoczeniem Europy była koncepcja prawdy objawionej. To ona uzasadniała dążenie do nawrócenia wszystkich ludów i uniwersalizacji zasad moralnych wszystkich grup etnicznych.

Thomas Woods postawił tezę, że Kościół nie tylko współkształtował cywilizację łacińską, ale że był wręcz jej twórcą. Jego zdaniem „wszystkie obszary takie jak myśl ekonomiczna, prawo międzynarodowe, nauka, życie uniwersyteckie, dobroczynność, poglądy religijne, sztuka, moralność stanowią fundament cywilizacji, a na Zachodzie każdy z nich wywodzi się z samego serca Kościoła katolickiego"19. Kościół zrewolucjonizował życie prywatne i publiczne, uświęcając życie człowieka (potępiając dzieciobójstwo, walki gladiatorów, porzucanie starych i chorych, niewolnictwo, samobójstwa, pojedynki, wojny zaborcze) oraz podnosząc znaczenie i godność małżeństwa. Dzięki działalności Kościoła sfera seksualna została ograniczona do łoża małżeńskiego, do wierności zobowiązani byli zarówno mąż, jak i żona, a brak rozwodów uniemożliwił porzucanie żony i poślubienie innej kobiety ${ }^{20}$.

Wprawdzie cywilizacja łacińska opierała się aż na czterech historycznych źródłach greckiej filozofii, rzymskim prawie, barbarzyńskim etnosie oraz religii chrześcijańskiej - to ta ostatnia stanowiła fundament dla kształtowania się zbiorowego światopoglądu. „Kościół, rozprzestrzeniając się po całym Zachodzie, dokonywał czegoś więcej niż wprowadzenia nowej wiary. Dogmat wznosił się wysoko ponad jednostkami i ich poglądami osobistymi. Mało kto go pojmował, niemniej był na tyle silny, że mógł narzucić wszystkim jednolite spojrzenie na świat. Dogmat wznosił się wysoko ponad królestwa i szczepy, ponad przeciwieństwa dzielące Rzymian i barbarzyńców [...]"21. W konsekwencji w późnym średniowieczu ,niepodważalne było przekonanie, że świat i człowiek, który go zamieszkuje, zostali stworzeni w ciągu sześciu dni przez Boga Ojca, wszechwiedzącą i szczodrobliwą inteligencję, i że musiał mieć On w tym jakiś wielki, skoro nieodgadniony cel"22.

Sposoby, jakimi dokonywano pogodzenia nowych treści z tradycjami helleńskimi, romańskimi i barbarzyńskimi, były niejednolite. Z jednej strony pierwotną religijność szału krzyża zastąpiono racjonalnym stylem myślenia ówczesnej elity Imperium Romanum. Jednocześnie dorobek antyku potraktowano instrumentalnie, zniekształcając go poprzez oderwanie od rzymskiej tradycji. Sytuacja, w której greckie i rzymskie teksty wykorzystywane były w średniowieczu z pominięciem swojego cywilizacyjnego tła, sprzyjała „systematycznej deformacji myśli pisarzy, nieustającemu anachronizmowi, myśleniu cytatami wyrwanymi z kontekstu"23. Św. Tomasz z Akwinu stwierdził nawet, że nie jest ważne to, co chcieli przekazać pisarze, lecz to, co napisali i z czego można

\footnotetext{
18 E. Gibbon, Upadek Cesarstwa Rzymskiego na zachodzie, PIW, Warszawa 2000, s. 382.

19 T. Woods, dz. cyt., s. 234-235.

20 Tamże, s. 227.

21 L. Genicot, dz. cyt., s. 59.

22 C. Becker, Państwo Boże osiemnastowiecznych filozofów, Zysk i S-ka, Poznań 1995, s. 12.

23 J. Le Goff, Kultura średniowiecznej Europy, „Marabut”, „Volumen”, Gdańsk-Warszawa 2002, s. 151.
} 
swobodnie korzystać ${ }^{24}$. Odczytanie dorobku antyku odbywające się w klasztorach benedyktyńskich nie miało na celu przyswojenia mądrości Greków i Rzymian. Zmierzało do podporządkowania prądów intelektualnych konkurencyjnych wobec powstającej teologii chrześcijańskiej w celu rozstrzygnięcia konfliktu pomiędzy dwiema, konkurencyjnymi koncepcjami prawdy i mądrości ${ }^{25}$. Ostatecznie w wielu obszarach przekaz Objawienia uległ samoograniczeniu, racjonalizacji, a niekiedy wręcz skapitulował przed barbarzyńskimi rozwiązaniami w obszarze życia społeczno-politycznego. Misja Kościoła zeszła na drugi plan wobec ziemskich wyzwań stojących przed potęgą polityczną, jaką się stał.

Wywodząca się z germańskich plemion hierarchia średniowiecznych społeczeństw przepełniania do głębi każdy obszar życia wspólnotowego. Biskup Ascelin tak pisał w roku 1000 do króla Roberta Pobożnego: „Dom Boży, o którym się sądzi, że jest jeden, podzielony jest na trzy części. Jedni się modlą, drudzy wojują, trzeci pracują. Te trzy części są solidarne i nie znoszą separacji. Usługi jednej z nich zależą od działań dwóch pozostałych; wzajemnie przyczyniają się one do podtrzymania wspólnoty. Ta zbiorowość trzech części tworzy w rzeczywistości jedną całość. W taki sposób triumfuje prawo i świat dotąd żyje w pokoju" "26. Ówczesne rozumienie pokoju bliskie było uporządkowaniu, zaprowadzeniu ładu. Podział władzy i zwierzchności pomiędzy trzema warstwami społecznymi nie był nigdy dany raz na zawsze. Jak w każdym społeczeństwie hierarchia była raczej wiecznym ścieraniem się konkurujących sił niż stałą strukturą podległości i dominacji. Ze względu na nieumiejętność koncyliacyjnego rozwiązywania konfliktów dążono do ich wyeliminowania. Procedury rozwiązywania sporów sprowadzały się bowiem do brutalnej przemocy wobec poddanych oraz klątw i represji w sporach między Kościołem a monarchią. Skala i częstotliwość konfliktów i buntów chłopskich mogła podważyć usankcjonowany religijnie porządek społeczny. Jego naruszenie nastąpiło bezpośrednio po podważeniu pozycji chrześcijaństwa - osłabieniu tendencji unifikacyjnych i uniwersalistycznych, powstałym na skutek nowych koncepcji epistemologicznych.

Cywilizacja łacińska w poznawaniu i wyjaśnianiu świata opierała się na zaufaniu pokładanym w uniwersalny, ponadczasowy wymiar wyznania wiary (credo). Wiek odrodzenia rozpoczął proces zmiany światopoglądu poprzez ukazanie kruchości ludzkiej wiedzy i zburzenie pewności, którą człowiek średniowiecza obdarzał swój religijny obraz świata. Nowe prądy ideowe przekształcały sposób myślenia, podobnie jak wcześniej powstanie

${ }^{24}$ Tamże, s. 151. Ten sam mechanizm funkcjonował nie tylko w odniesieniu do pisarzy grecko-rzymskich, ale również do Pisma Świętego. Słowo Boże zagubiło się pośród niezliczonych egzegez, komentarzy, kluczy i wyjaśnień. Powszechna dostępność została okupiona streszczeniami, omówieniami, cytatami, które przekształciły Biblię w zbiór maksym i anegdot. Tamże, s. 152.

25 Tym niemniej oparcie się na antyku było istotnym źródłem odróżnienia się od cywilizacji bizantyjskiej, czerpiącej z tradycji greckiej i orientalnej. „Obie nawiązywały do innych źródeł i posiadały na sobie różne naloty: cywilizacja łacińska posiadała elementy rzymsko-chrześcijańsko-germańskie, natomiast cywilizacja bizantyjska składała się z pierwiastków grecko-hellenistyczno-chrześcijańskich”. A. Bokiej, Cywilizacja łacińska, „Atla 2”, Legnica 2000, s. 112-113. Według Feliksa Konecznego podstawowymi różnicami pomiędzy dwiema powstałymi na gruzach Imperium Romanum cywilizacjami były kwestie relacji państwo-społeczeństwo i supremacji sił duchowych nad fizycznymi. Katolicyzm w przeciwieństwie do chrześcijaństwa wschodniego podporządkowywał siły materialne siłom duchowym. F. Koneczny, Cywilizacja bizantyńska, Wydawnictwo Antyk Marcin Dybowski, Komorów 1996, s. 103.

${ }^{26}$ Cyt. za: J. Baszkiewicz, dz. cyt., s. 11. 
filozofii zmieniło Greków, a nauczanie Chrystusa - Rzymian i barbarzyńców. Ostatnią próbą ratowania dawnych form był scholastyczny wysiłek rozumowego podparcia gmachu świata chrześcijańskiego. Oparcie przez św. Tomasza Akwinaty doktryny religijnej na podstawie racjonalnej apologetyki wystawiło ją jednocześnie na deliberatywną krytykę prowadzoną na gruncie metodologii Kartezjusza.

Kartezjusz wniósł do epistemologii dowolność w wyborze prawdy, którą nazywamy spekulatywnością rozumowania. Wprowadził dowolność określania znaczenia pojęć, wyzwolił nas od ograniczeń rzeczywistości, odrzucając pierwotną wartość poznania zmysłowego czy zdrowego rozsądku. Uczynił rozum jedyną władzą zdolną określać, czym jest rzeczywistość. Uczeń Kartezjusza, Nicolas Malebranche pisał: „nie słuchaj swoich zmysłów! Odwołuj się do tego, co uznasz w sobie za najbardziej rozświetlone i najmniej skłonne do błędu”27. „Wiedz jednak, że wszystko, co pochodzi do duszy przez ciało, służy tylko ciału i że zmysły przemawiają należycie tylko dla własnej korzyści, a jeżeli zechcesz użyć ich świadectwa, aby upewnić się co do prawdy samej w sobie, nie unikniesz nigdy pomyłki" 28 .

Metoda powszechnego zwątpienia przedstawiona w Rozprawie o metodzie polegała na odrzuceniu wszelkich prawd i przekonań oraz budowaniu na nowo porządku świadomości w oparciu o zasady spekulatywnego (a więc oderwanego od rzeczywistości) rozumowania. „Za pomocą tej metody można zaatakować wszystko, co dawne, aby utorować drogę wszystkiemu, co nowe"29. Odgórna prawda o świecie została zastąpiona swobodą kształtowania własnego światopoglądu.

Realizacja naukowej metody powszechnej krytyki wymagała pozbawienia autorytetu tradycji i elit społecznych. „Cóż bowiem oznacza życie w świecie politycznym, wyzbytym zarówno autorytetu, jak i towarzyszącej mu świadomości, że źródło autorytetu przewyższa władzę i tych, którzy są u władzy. Otóż oznacza ono, że pozbawieni religijnej ufności w święty początek, pozbawieni ochrony w postaci tradycyjnych, a tym samym oczywistych wzorów postępowania, na nowo stajemy wobec elementarnych problemów życia we wspólnocie ludzkiej" ${ }^{30}$. Pozbawieni autorytetu prawdy wracamy niejako do czasów przedcywilizowanych, cofamy się ze świata kultury do świata natury.

Rozwinięciem dorobku Kartezjusza była metodologia stworzona przez Karla Poppera, według którego ,„...] poza wąską dziedziną logiki i być może matematyki nie istnieją żadne dowody. Upraszczając zaś nieco: niczego nie można dowieść. Można wprawdzie przytoczyć argumenty i można badać krytycznie poglądy, lecz poza matematyką nasza argumentacja nigdy nie jest rozstrzygająca" ${ }^{31}$. Zdaniem Poppera przyjęcie pewnego stanowiska, o ile odbywa się świadomie, jest efektem decyzji podejmowanej z dobrą bądź

${ }_{27}$ N. Malebranche, Medytacje chrześcijańskie i metafizyczne, Znak, Kraków 2002, s. 31.

28 Tamże, s. 69.

29 P. Kłoczowski, Rewolucja kartezjańska, [w:] tegoż(red.), Dziedzictwo greckie we współczesnej filozofii politycznej, „Księgarnia Akademicka”, Kraków 2004, s. 65-66.

${ }^{30}$ H. Arendt, Między czasem minionym a przeszłym. Osiem ćwiczeń z myśli politycznej, Fundacja „Aletheia", Warszawa 1994, s. 174.

${ }^{31}$ K. Popper, W poszukiwaniu lepszego świata. Wykłady i rozprawy z trzydziestu lat, „Książka i Wiedza”, Warszawa 1997, s. 241. 
złą wolą, jest aktem woli opartym na osądzie rozumu. Nigdy nie może mieć miejsca przyjęcie prawdy jako takiej, na mocy przyrodzonej jej prawdziwości. Na gruncie tej koncepcji prawdy każdy porządek społeczny jest rodzajem eksperymentu. Podpartym pewnymi argumentami, ale niemożliwym do ostatecznego zaakceptowania jako najlepszy możliwy (a co najwyżej najlepszy dostępny).

Popper postulował sprowadzenie badań do zaproponowania jakiegoś rozwiązania i poddania go krytyce w celu weryfikacji postawionej hipotezy. „Jeśli próba rozwiązania nie jest dostępna rzeczowej krytyce, to właśnie dlatego zostaje wyeliminowana jako nienaukowa, choć być może jedynie chwilowo. Jeśli jest dostępna rzeczowej krytyce, wówczas próbujemy ją obalić; wszelka krytyka polega bowiem na próbach obalenia. Jeśli próba rozwiązania zostaje obalona przez naszą krytykę, proponujemy inne rozwiązanie. Jeśli oprze się krytyce, wówczas akceptujemy ją tymczasowo; to znaczy akceptujemy ją przede wszystkim jako zasługującą na dalszą dyskusję i krytykę" ${ }^{32}$. Filozof proponował, aby zaakceptowane rozwiązanie zachowywać nie dlatego, że jest prawdziwe, lecz dlatego, że nie potrafimy go odrzucić.

Oświeceniowa, niekompletna i relatywistyczna koncepcja prawdy łatwo uległa degradacji w postulowany przez postmodernistów relatywizm, który stał się podstawą nie tylko dla rozważań epistemologicznych, ale również dla kształtu stosunków społecznych. Relatywizm kulturowy był narzędziem ataku na etnocentryzm cywilizacji łacińskiej. Opierał się na założeniu, że „każda kultura to samoistna «monada», metafizyczny wszechświat sam w sobie i sam dla siebie"33. Konsekwencją takiego rozumienia poszczególnych kultur była niemożność oceny norm w niej postulowanych. Relatywiści uznają, że „,wypowiedzi normatywne pozbawione są znaczenia poznawczego i sensu empirycznego i służą jedynie wzbudzeniu emocji, natomiast etyczne wypowiedzi normatywne wyrażają jedynie stany umysłu, a nie stany poznawcze [...] wypowiedź typu «to jest dobre» musiała być traktowana jako wyrażalna w kategoriach «ja to aprobuję» lub «mnie się to podoba». Zasady moralne zyskiwały tym samym charakter subiektywny, wyrażały bowiem warunkujące je (czyjeś) partykularne preferencje" ${ }^{\text {"34 }}$.

Wymiar refleksji normatywnej wypychany jest aktualnie z dyskursu naukowego. Odrzuca się wszelkie nacechowane emocjonalnie określenia wartościujące również w nauce o polityce. „Na gruncie pozytywistycznym usprawiedliwiona byłaby zatem jedynie behawioralna $\mathrm{i}$ «redukcyjna» nauka o polityce, zaś teoria polityki miałaby być traktowana jako analogiczna do nauk przyrodniczych: ograniczać się do uogólniania danych o faktach dziejących się aktualnie i tych, które składały się na procesy długoterminowe, albo «przeistaczać się» W metodologię badań empirycznie uchwytnych faktów, stając się tym samym «nauką wyłącznie empiryczną», w żadnym razie normatywną, wyjaśniającą jedynie, a nie kierunkującą, z konieczności «moralnie neutralną» i nieuwzględniającą żadnej «twardej koncepcji dobra» [...]"35. Taka koncepcja teorii polityki, lub szerzej, rozumienia

32 Tamże, s. 85.

33 W. Burszta, W. Kuligowski, dz. cyt., s. 132.

${ }^{34}$ B. Pietrzyk-Reeves, B. Szlachta, Wstęp, [w:] tychże (red.), Wspótczesna filozofia polityki. Wybór tekstów źródłowych, „Dante”, Kraków 2003, s. 13.

35 Tamże, s. 14. 
świata społecznego ogranicza kompetencje człowieka do wydawania sądów o faktach, z wyjąatkiem sądów wartościujących. Odmawia tym samym możliwości postulowania na gruncie metodologii naukowej pożądanego kształtu porządku politycznego. Nie sposób budować go, nie ustaliwszy uprzednio aksjologicznego punktu oparcia. Dlatego też wśród wyrosłych na pozytywizmie liberałów powszechny jest pogląd, że demokracja opiera się na braku obiektywnej prawdy i wartości. Nie sposób zatem znaleźć nawet punktu oparcia dla tolerancji, praw człowieka i państwa prawa ${ }^{36}$.

Z kolei miejsce prawdy objawionej przejęła nauka z jej wizjami mechanicznej przyrody i człowieka. Joyce Appleby, Lynn Hunt i Margaret Jacobs opisali model nauki heroicznej, której przedstawiciele od czasów oświecenia stawali się bohaterami kultury. „Osiemnastowieczni filozofowie, wspomagani przez politycznych reformatorów i przemysłowców, wymyślili model nauki heroicznej. Stanęli na czele międzynarodowego ruchu reformatorskiego zwanego oświeceniem, a nauka okazała się ich głównym orężem W walce z tradycyjnymi instytucjami - z Kościołem i państwem" ${ }^{37}$. Dzieła literatury XIX-wiecznej pełne są przykładów szacunku, jakim obdarzano naukowców pomimo ich roztargnienia, niskiej pozycji społecznej, nikłych zalet towarzyskich, małego majątku czy braku zaradności życiowej. Respekt wobec obiektywnej, racjonalnej nauki obejmował również jej przedstawicieli. Wysoka pozycja nauki przyniosła wielkie pożytki w medycynie czy inżynierii, usuwając zagrożenia związane z klęskami głodu, najazdami obcych ludów, epidemiami, katastrofami naturalnymi. Ich eliminacja powoduje, że od trzystu lat nie podważają powszechnego poczucia bezpieczeństwa egzystencjalnego większości społeczeństwa rozwiniętego świata Zachodu. Możemy pozwolić sobie na kulturową akceptację niepewności światopoglądu, nieustanny spór o podstawowe zasady i wartości życia społecznego, gdyż współczesny świat oferuje nam bezpieczeństwo materialne.

Współcześni ludzie chociaż nie wiedzą, kim są, gdzie żyją i po co, chociaż nie są zgodni co do tego, jak powinni żyć i do czego dążyć, pełnym zaufaniem darzą instytucje państwa, porządek prawny gwarantujący bezkonfliktowe współżycie oraz gospodarkę kapitalistyczną, dostarczającą wszelkich niezbędnych do wygodnego życia dóbr. Możemy sobie zatem pozwolić na przyjęcie koncepcji prawdy, która jest jedynie niezobowiązującą konwencją, która niczego ostatecznie nie przesądza i nie rozstrzyga. Zachwycające sukcesy, jakie osiągnęły nauki ścisłe i inżynieryjne w wyjaśnianiu i opanowywaniu sił natury, pozwoliły nam zaakceptować kartezjańską metodę powszechnego wątpienia i popperowską koncepcję prawdy jako hipotezy, której nie zdołaliśmy jeszcze obalić. Przyjęliśmy aksjomat, że prawda absolutna nie istnieje, a nawet jeśli, to nie jesteśmy w stanie jej dowieść.

$\mathrm{Z}$ drugiej strony rozwiązanie to wciąż jest niedoskonałe i powoduje nieustające konflikty. Dopóki nie zmieni się pozycja prawdy, poszukiwanie właściwej formy organizacji życia społecznego nigdy się nie zakończy. Nawet dobrowolnie zaakceptowane, postępowe autorytety w następnym pokoleniu znajdą swoich krytyków. Dlatego też Europa, żyjąca

${ }^{36}$ Z. Drozdowicz, Liberalne wartości i ich wrogowie, [w:] tegoż (red.), Europa wspólnych wartości, t. 3, Wydawnictwo Fundacji Humaniora, Poznań 2006, s. 64-65.

37 J. Appleby, L. Hunt, M. Jacobs, Powiedzieć prawdę o historii, Zysk i S-ka, Poznań 2000, s. 23. 
w porządku cywilizacji oświecenia, nigdy nie zazna spokoju, będzie rozdzierana ciągłymi sporami ${ }^{38}$. Brakuje nam uzasadnień dla podstawowych kategorii egzystencjalnych, nie istnieją fundamenty, na których moglibyśmy oprzeć nasze życie. Poruszamy się w kulturowej pustce, której elity intelektualne nie próbują nawet wypełnić treścią. Zajmują się za to tworzeniem uzasadnień dla idei, które warunkują istnienie pustki - relatywizmu, tolerancji, pluralizmu. Jesteśmy zamknięci w doczesności, której nie potrafimy wykorzystać, gdyż brakuje nam aksjologicznego oparcia, na którym moglibyśmy budować projekty wspólnotowych działań. Współczesna cywilizacja rozminęła się z duchowymi potrzebami człowieka. Jak pisał Emil Cioran, ,jesteśmy na świecie, aby zmagać się z życiem i śmiercią, a nie, by je omijać, jak to nam podpowiada cywilizacja - urządzenie do maskowania, szminkowania spraw nierozwiązywalnych. Ponieważ nie zawiera ona w sobie żadnej zasady trwałości, jej zalety to tylko ślepe zaułki, więc nie pomagają nam ani lepiej żyć, ani lepiej umierać"39.

Która tendencja zwycięży? Czy technologia zapewni nam satysfakcjonujące poczucie bezpieczeństwa, które skutecznie zminimalizuje ideologiczny chaos konkurujących ze sobą prawd i stylów życia? Trwałość oświeceniowego zrzeszenia cywilizacyjnego będzie z pewnością wystawiona na trudną próbę przez zewnętrzny nacisk ekspansywnego islamu politycznego. Każda cywilizacja, jaka niesie wysokie wymagania, potrzebuje zaangażowania w obronę swoich podstaw. Cywilizacja oświecenia zmusza do samodzielnego wyboru swojej tożsamości i sensu życia. To nie jest łatwy wybór, ale w zamian oferuje ogromny zakres swobody, niezależność jednostek, możliwość partycypacji we władzy i korzystania z dorobku rozwoju technologiczno-ekonomicznego. Przyszłość pokaże, czy społeczeństwa Zachodu będą skłonne, aby walczyć w obronie swojego sposobu życia oraz czy będą miały wewnętrzną siłę, by dokonywać w każdym pokoleniu i w każdym indywidualnym przypadku najtrudniejszego (i obarczonego ryzykiem błędu) wyboru własnej tożsamości i sensu swojego życia.

\section{Bibliografia}

Appleby J., Hunt L., Jacobs M., Powiedzieć prawdę o historii, Zysk i S-ka, Poznań 2000.

Arendt H., Między czasem minionym a przeszłym. Osiem ćwiczeń z myśli politycznej, Fundacja „Aletheia”, Warszawa 1994.

Baszkiewicz J., Myśl polityczna wieków średnich, Wydawnictwo Poznańskie, Poznań 1998.

Becker C., Państwo Boże osiemnastowiecznych filozofów, Zysk i S-ka, Poznań 1995.

Bierdiajew M., Nowe średniowiecze. Los człowieka we współczesnym świecie, Fundacja „Aletheia”, Warszawa 2003.

Bokiej A., Cywilizacja łacińska, „Atla 2”, Legnica 2000.

Cioran E., Upadek w czas, Wydawnictwo „Aletheia”, Warszawa 2008.

38 P. Hazard, Kryzys świadomości europejskiej 1680-1715, PIW, Warszawa 1974, s. 387.

39 E. Cioran, Upadek w czas, Wydawnictwo Aletheia, Warszawa 2008, s. 50. 
Dawson C., Tworzenie się Europy, „Pax”, Warszawa 2000.

Drozdowicz Z., Liberalne wartości i ich wrogowie, [w:] tegoż (red.), Europa wspólnych wartości, t. 3, Wydawnictwo Fundacji Humaniora, Poznań 2006.

Genicot L., Powstaje nowy świat. Studium o kulturze i cywilizacji wieków średnich, „Pax”, Warszawa 1964.

Gibbon E., Upadek Cesarstwa Rzymskiego na zachodzie, PIW, Warszawa 2000.

Hazard P., Kryzys świadomości europejskiej 1680-1715, PIW, Warszawa 1974.

Husserl E., Kryzys europejskiego człowieczeństwa a filozofia, Fundacja „Aletheia”, Warszawa 1993.

Jaeger W., Paideia, Fundacja „Aletheia”, Warszawa 2001.

Kłoczowski P., Rewolucja kartezjańska, [w:] tegoż(red.), Dziedzictwo greckie we współczesnej filozofii politycznej, „Księgarnia Akademicka”, Kraków 2004.

Koneczny F., Cywilizacja bizantyńska, Wydawnictwo Antyk Marcin Dybowski, Komorów 1996.

Le Goff J., Kultura średniowiecznej Europy, „Marabut”, „,Volumen”, Gdańsk-Warszawa 2002.

Leciejewicz L., Nowa postać świata. Narodziny średniowiecznej cywilizacji europejskiej, Wydawnictwo Uniwersytetu Wrocławskiego, Wrocław 2007.

Malebranche N., Medytacje chrześcijańskie i metafizyczne, Znak, Kraków 2002.

Maritain J., O nowa cywilizację chrześcijańska, Towarzystwo Wiedzy Chrześcijańskiej, Lublin 1935.

Maritain J., Pisma filozoficzne, Znak, Kraków 1988.

Maritain J., Nauka i mądrość, Fronda, Apostolicum, Warszawa-Ząbki 2005.

Mead M., Kultura i tożsamość: studium dystansu międzypokoleniowego, PWN, Warszawa 2000.

Pietrzyk-Reeves B., Szlachta B., Wstęp, [w:] tychże (red.), Współczesna filozofia polityki. Wybór tekstów źródłowych, „Dante”, Kraków 2003.

Popper K., W poszukiwaniu lepszego świata. Wykłady i rozprawy z trzydziestu lat, „Książka i Wiedza", Warszawa 1997.

Sobczak J., Zmierzch cywilizacji, Wydawnictwo Naukowe INPiD UAM, Poznań 2002.

Woods T., Jak Kościót katolicki zbudował zachodnia cywilizację, Wydawnictwo AA, Kraków 2006.

\section{Streszczenie \\ Bezpieczeństwo egzystencjalne społeczeństw Zachodu wobec współczesnego sporu epistemologicznego}

Koncepcja prawdy stanowi ważny czynnik budowania bezpieczeństwa egzystencjalnego, czyli przekonania, że wartości i cele realizowane w życiu jednostek i wspólnot są warte ochrony. Źródła pewności naszej pozycji w świecie zmieniają się wraz z cywilizacjami. W antyku dominowała narracja filozoficzna, w cywilizacji łacińskiej religijna, a współcze- 
śnie - racjonalna, pragmatyczna kalkulacja funkcjonalistyczna. Zgadzamy się na redukcjonistyczną koncepcję prawdy, która obowiązuje tylko na mocy społecznej konwencji, otrzymując w zamian korzyści bezprecedensowej wolności i wygody życia. Autor opisuje historyczne napięcia przechodzenia pomiędzy trzema cywilizacjami oraz spory epistemologiczne, jakie się wówczas rodziły.

Słowa kluczowe: bezpieczeństwo, kultura, cywilizacja, prawda, epistemologia, społeczeństwo

\section{Summary}

The influence of contemporary epistemological disputes on the existential security of Western societies

The idea of truth is an important factor for building existential security - the belief that our values and goals are worth pursuing in the lives of individuals and communities. The sources of the certainty of our position in the world tends to change together with civilisation. In Antiquity the leading position belonged to the philosophical narrative, in Latin civilisation it was religion and in contemporary civilisation it is rational and pragmatic calculation. We have agreed to the reductionist idea of truth, which is only valid as a social contract. In return we receive the benefits of historically unprecedented freedom and comfort of living. The author describes the historical tensions between three consecutive European civilisations and the epistemological disputes they have created.

Keywords: security, culture, civilisation, truth, epistemology, society 


\section{(Nie)Bezpieczna Europa po Brexicie?}

\section{Wstęp}

Szok wywołany decyzją referendalną Brytyjczyków o wyjściu z Unii ${ }^{1}$ postawił na wokandzie problematykę jedności politycznej Zachodu, niezbędnej do zachowania bezpieczeństwa i stabilności naszego kontynentu. Ponieważ obronność jest zagadnieniem zbyt ważnym, aby pozostawić go tylko wojskowym, warto dokonać egzegezy politologicznej zaistniałej sytuacji, tym bardziej, że wspólnotę opuści jedyne, oprócz Republiki Francuskiej, państwo unijne posiadające potencjał nuklearny oraz stałe miejsce w Radzie Bezpieczeństwa ONZ. Co więcej, Wielka Brytania posiada zupełnie unikatowe zdolności w dziedzinie projekcji siły, czego rezultatem jest jej obecność militarna w wielu regionach globu. Potęgę Zjednoczonego Królestwa niewątpliwie wspiera fakt przeznaczania przez nią powyżej 2\% PKB na obronność, co stanowi niestety rzadko spotykaną okoliczność w gronie państw wspólnoty euroatlantyckiej. Mogłoby się zatem wydawać, iż wystąpienie Wielkiej Brytanii ze wspólnoty zada potężny cios marzeniom o utworzeniu autonomicznych możliwości obronnych Unii Europejskiej, z uwagi na spodziewaną utratę brytyjskich zasobów, niezbędnych do kreowania strategicznych działań wojskowych tej organizacji. Wprawdzie Londyn odpowiada za blisko czwartą część unijnych wydatków na militaria, jednak - paradoksalnie - do tej pory pokrywał on ledwie około $15 \%$ kosztów operacji prowadzonych pod auspicjami wspólnoty, dostarczając tylko około 7\% personelu na wspomniane potrzeby.

Należy przyznać, iż w sferze politycznej Wielka Brytania nie wykazywała zainteresowania wszechstronnym rozwojem zdolności operacyjnych Unii, przyznając w tym względzie prymat Sojuszowi Północnoatlantyckiemu. Nie tylko ignorowała ona postulaty przyjęcia przez struktury europejskie większej odpowiedzialności za bezpieczeństwo kontynentu,

1 W dniu 23 czerwca 2016 roku odbyło się w Wielkiej Brytanii referendum dotyczące jej członkostwa w Unii Europejskiej, w którym 51,89\% Brytyjczyków opowiedziało się za wyjściem ze wspólnoty. 
ale wręcz wetowała kolejne inicjatywy, mogące doprowadzić do wzmocnienia wspólnoty w dziedzinie obronności. W optyce Londynu organizacja ta miała bowiem stanowić forum współpracy gospodarczej, pozostawiając domenę militarną działalności NATO, z naczelną rolą Stanów Zjednoczonych. Z biegiem czasu współpraca unijna zaczęła jednak obejmować pola bezpośrednio związane z problematyką bezpieczeństwa, toteż dziś wystąpienie Wielkiej Brytanii ze wspólnoty rodzi niebagatelne pytania o przyszłość zjednoczonej Europy na płaszczyźnie wojskowej.

\section{Konceptualizacja ładu europejskiego po Brexicie}

Decyzja Zjednoczonego Królestwa o wyjściu z Unii Europejskiej powinna skłaniać obywateli do debaty na temat nowego modelu bezpieczeństwa Europy, który ujawni się w następstwie procesów dekompozycyjnych wspólnoty. W ujęciu teoretycznym zdarzenie to ukazuje problematykę stabilności naszego kontynentu w całej jej złożoności, dotykając nie tylko dziedziny wojskowości, ale także aspektów społecznych, politycznych i gospodarczych. Brexit wpisuje się w wielowątkową dyskusję o istocie bezpieczeństwa we współczesnym świecie, a także naturze aktualnych zagrożeń stojących przed wspólnotą euroatlantycką. Zjawisko to może bowiem spowodować upadek dotychczasowych paradygmatów, organizujących myślenie Zachodu na tematy strategiczne, czyniąc zagadnienie bezpieczeństwa jeszcze bardziej skomplikowanym i nieoczywistym. Jest ono także zapowiedzią wyłonienia się zupełnie nowych koncepcji, jeszcze nieznanych ekspertom i analitykom, których realizacja może pogłębić amorficzność i fragmentaryczność europejskich struktur obronnych. Niełatwo będzie bowiem wdrożyć formuły współpracy, odznaczające się efektywnością, a zarazem pozostające w zgodzie z pragnieniem Brytyjczyków do pozostawania poza wspólnotą. Ponieważ wystąpienie Zjednoczonego Królestwa z Unii może podważać dotychczasowe schematy bezpieczeństwa, Brexit w ujęciu planistycznym należy ocenić jako źródło potencjalnego ryzyka w coraz bardziej niepewnym świecie. Niewątpliwie liberalne instytucje zachwiały się pod naporem procesów odśrodkowych, co potencjalnie prowadzić może do reorganizacji ładu europejskiego w przyszłości. Niewykluczone jest pogłębienie współpracy w obrębie mniejszej liczby państw Unii w oparciu o zupełnie nowe modele integracji, skutkujące sprowadzeniem kooperacji obronnej do „twardego rdzenia” organizacji. Ta swoista „Europa wielu «militarnych» prędkości” może wygenerować architekturę bezpieczeństwa kontynentu, charakteryzującą się nieregularnością i asymetrycznością, z prawdopodobnym uszczerbkiem dla tzw. krajów flankowych, w tym Rzeczypospolitej².

W ocenie badaczy Brexit doprowadzi najpewniej do wzajemnego osłabienia gospodarczego Wielkiej Brytanii i Unii, erupcji nacjonalizmów, a także podważenia bezalternatywności procesów zjednoczeniowych, prowadząc do zmniejszenia zdolności obronnych wspólnoty euroatlantyckiej. Co więcej, analizowane zdarzenie może dobitnie unaocznić

2 A. MacDowall, Brexit Raises Economic and Security Fears in Central and Eastern Europe, „World Politics Review" 2016, 21 June, https://www.worldpoliticsreview.com/articles/19134/brexit-raises-economicand-security-fears-in-central-and-eastern-europe [dostęp: 24.06.2018]. 
Zachodowi, że w dzisiejszym świecie bezpieczeństwo jest zwykłym towarem, stanowiącym przedmiot gorszących targów między sojusznikami, i to pomimo wzajemnych zapewnień, iż ich zaangażowanie w kolektywną obronę jest bezwarunkowe. Tym samym pojawi się pokusa dokonania zgubnych podziałów poprzez zastąpienie wielostronnej współpracy umowami o charakterze bilateralnym. Jak się zdaje, Brexitu nie można skwitoß̉ać - zwłaszcza na płaszczyźnie bezpieczeństwa - neofunkcjonalistycznym ,spill-back" , ponieważ takie fenomeny, jak terroryzm czy rewizjonistyczna polityka Federacji Rosyjskiej, powinny skłaniać do pogłębiania obecnych mechanizmów współpracy, a nie zrywania tak potrzebnego współdziałania. Istniejące teorie integracji niestety nie dają klarownej odpowiedzi na pytanie o optymalny kształt przyszłych powiązań między Zjednoczonym Królestwem a Unią Europejską, co uzasadnia potrzebę prowadzenia dalszych badań w tym zakresie.

\section{Rola Wielkiej Brytanii po wystąpieniu z UE}

Dla wielu Brytyjczyków przeświadczonych o statusie imperialnym Zjednoczonego Królestwa przystąpienie ich kraju do wspólnoty w latach 70. XX wieku stało się synonimem degradacji. Wielka Brytania jako państwo narodowe - w ocenie jej obywateli - zdała bowiem egzamin w okresie II wojny światowej. Nie doświadczyła ona utraty niepodległości, stąd legendarny sceptycyzm jej społeczeństwa w odniesieniu do udziału w procesach integracyjnych, zwłaszcza w tak drażliwych dziedzinach, jak polityka zagraniczna i obronność. Na Wyspach obecne jest przeświadczenie, że Zjednoczone Królestwo poradzi sobie poza strukturami UE, gdyż to Europa bardziej pottzebuje brytyjskich zdolności wojskowych aniżeli Londyn dostępu do jednolitego rynku .

W epoce globalizacji status wyspiarski Wielkiej Brytanii może jednak nie dawać należytych gwarancji bezpieczeństwa, nawet przy założeniu przywrócenia kontroli nad własnymi granicami na skutek wystąpienia z Unii. Natura współczesnych wyzwań wydaje się bowiem wręcz wymagać partycypacji we wspólnych instytucjach, ułatwiających kooperację międzynarodową - przykładowo w zakresie wymiany danych wywiadowczych. Wszak terroryści - atakując europejskie wartości - nie wykazują większego respektu dla granic państw narodowych, toteż Brexit najpewniej pozbawi obie strony części narzędzi służących do skutecznego zwalczania istniejących zagrożeń.

To symptomatyczne, że jedną z przyczyn secesji ze wspólnoty był strach Brytyjczyków przed unijnymi migrantami, korzystającymi ze swobód rynku wewnętrznego w Zjednoczonym Królestwie. W tym ujęciu Unia jawiła się jako źródło ryzyka dla zwolenników Brexitu, którzy postrzegali swobodę przepływu osób oraz wspólnotowe podejście do kryzysu uchodźczego jako zjawiska mogące potencjalnie podważyć stabilność politycz-

\footnotetext{
3 P.J. Borkowski, Polityczne teorie integracji międzynarodowej, Centrum Doradztwa i Informacji Difin, Warszawa 2007, s. 91-103.

${ }^{4}$ P. Oltermann, Theresa May wants new security treaty with EU next year, ,The Guardian” 2018, 17 February, https://www.theguardian.com/politics/2018/feb/17/theresa-may-wants-new-security-treaty-with-eu-nextyear [dostęp: 24.06.2018].
} 
ną Europy. Przywrócenie kontroli nad swymi granicami - jako następstwo opuszczenia Unii - ma zatem przyczynić się do wzrostu subiektywnego poczucia bezpieczeństwa obywateli brytyjskich.

Ubocznym skutkiem wyjścia Wielkiej Brytanii z rynku wewnętrznego oraz unii celnej może stać się jednak przywrócenie tzw. twardej infrastruktury między Republiką Irlandii a Irlandią Północną, co raczej nie umocni procesu pokojowego, toczącego się w tym regionie. Niewątpliwie mechanizmy Unii, poprzez swobodną cyrkulację czynników produkcji oraz ludzi, przyczyniły się do obniżenia poziomu napięcia między północą a południem Irlandii. Nie jest wcale pewne, czy Porozumienie Wielkopiątkowe z 1998 roku zostałoby podpisane, gdyby nie funkcjonowanie obu państw w strukturach europejskich. Bez wątpienia konflikt irlandzki udało się załagodzić dzięki wykorzystaniu przez Wielką Brytanię i Irlandię dobrodziejstw napływających ze zjednoczonej Europy, gdyż swobody jednolitego rynku umożliwiły integrację tamtejszych społeczności przy zachowaniu podziału politycznego wyspy. Granica między oboma obszarami mogła bowiem pozostać otwarta dla przepływu osób, towarów, usług i kapitału, pozwalając tym samym na zachowanie osobistych kontaktów Irlandczyków. W tym sensie Brexit doprowadzi do podkopania fundamentów trudnego pokoju, który udało się zbudować w tej części kontynentu m.in. dzięki narzędziom wspólnoty europejskiej ${ }^{5}$.

Odejście od unijnego obywatelstwa, jako następstwo wyjścia Zjednoczonego Królestwa z Unii, może doprowadzić do podważenia praw zwykłych ludzi, którzy skorzystali z mobilności na rynku wewnętrznym Unii. Z uwagi na sprowadzanie jednostek do statusu migrantów z państw trzecich ich sytuacja w Zjednoczonym Królestwie oraz w UE-27 stanie się niezwykle złożona. Zostaną oni bowiem zepchnięci do swoistego limbus, co może skutkować „,prekaryzacją” ich dotychczasowej pozycji społecznej. W myśl europejskich regulacji obywatele Unii mogą być usuwani przez państwa przyjmujące tylko ze względu na bezpieczeństwo, zdrowie lub porządek publiczny. Brexit zapowiada wydalanie wspólnotowych migrantów z terytorium Wielkiej Brytanii, a zarazem Brytyjczyków z obszaru pozostałych krajów członkowskich, bez uwzględnienia ich wieku, stanu zdrowia bądź sytuacji rodzinnej. Zdarzenie to może doprowadzić do masowej dyskryminacji obywateli UE-27 w Zjednoczonym Królestwie oraz Brytyjczyków na terytorium Unii, powodując ich faktyczne wykluczenie ze wspólnot państw przyjmujących .

W następstwie opuszczenia wspólnoty Wielka Brytania utraci też częściowo wpływ na europejskie sąsiedztwo, na które do tej pory oddziaływała m.in. poprzez unijne instrumentarium. Powyższe wynika z planowanej reorientacji polityki Albionu, realizowanej pod hasłem „Global Britain”, która oznacza skupianie się na sprawach światowych kosztem zagadnień lokalnych. Paradoksalnie, w dobie prezydentury D. Trumpa, generującej sporą niepewność co do strategicznych kierunków polityki amerykańskiej, w Londynie może pojawić się pokusa bliższej współpracy z partnerami europejskimi w zakresie bezpieczeń-

5 E. Burke, Brexit and the threat to Northern Ireland, „CER Bulletin” 2017, Issue 115, August/September, http://www.cer.eu/sites/default/files/bulletin 115 eb article1.pdf [dostęp: 24.06.2018].

${ }^{6}$ M. Goodwin, C. Milazzo, Taking back control? Investigating the role of immigration in the 2016 vote for Brexit, „,The British Journal of Political Science and International Relations” 2017, Vol. 19, Issue 3, s. 450. 
stwa. Jeśli bowiem Wielka Brytania przestanie być pomostem łączącym Unię ze Stanami Zjednoczonymi, z pewnością dojdzie do obniżenia jej znaczenia w ramach Sojuszu Północnoatlantyckiego. Dziś można jedynie spekulować, czy analizowane zdarzenie doprowadzi do zgubnego w skutkach unilateralizmu lub izolacjonizmu w działaniach zewnętrznych Zjednoczonego Królestwa ze stratą dla obronności całej wspólnoty euroatlantyckiej.

Oczywistą konsekwencją Brexitu stanie się również niemożność udziału Wielkiej Brytanii w unijnych spotkaniach, poświęconych wydarzeniom międzynarodowym, czego rezultatem może być rozdźwięk między partnerami w ocenie sytuacji na świecie. W istocie Londyn nie będzie mógł oddziaływać na procesy decyzyjne wspólnotowych gremiów z uwagi na ich autonomię regulacyjną. Powyższe skutkować może niechęcią Zjednoczonego Królestwa do finansowej partycypacji w projektach militarnych, na który utraci jakikolwiek wpływ. Ponadto państwo to nie będzie mogło dowodzić unijnymi misjami, choć jego dotychczasowy wkład w tego typu operacje oszacować należy, pomimo znacznego potencjału, jako zadziwiająco skromny. Przykładowo w 2013 roku Wielka Brytania zablokowała pomysł wysłania unijnej misji do Republiki Środkowej Afryki, mającej na celu wsparcie działań Francji, w obawie o oddziaływanie tego wydarzenia na rodzimą debatę dotyczącą przyszłości jej członkostwa we wspólnocie. Z deklaracji brytyjskiego rządu wynika wprawdzie wola pozostawania kluczowym graczem w sferze obronności europejskiej, ale tylko przy pomocy narzędzi Sojuszu Północnoatlantyckiego, wraz z zamiarem blokowania ewentualności utworzenia wspólnych sił zbrojnych, które mogłyby zaszkodzić pozycji NATO.

Kolejnym następstwem secesji tego kraju z Unii jest wzajemne osłabienie obu stron na płaszczyźnie stricte gospodarczej ${ }^{7}$. Wyjście Zjednoczonego Królestwa z rynku wewnętrznego i unii celnej zapewne spowolni odbudowę Europy po kryzysie ekonomicznym, co wpłynie niewątpliwie na jej strategiczne zdolności obronne. Co więcej, Wielka Brytania zostanie wyłączona z tych sfer unijnej współpracy, które bezpośrednio dialogują z problematyką bezpieczeństwa, tj.: handlu, klimatu, energii czy też pomocy humanitarnej. Tym samym Londyn utraci dostęp do wspólnotowych instrumentów oddziaływania na środowisko zewnętrzne, takich jak fundusze, sankcje albo perspektywa członkostwa w tej organizacji. Dodatkowo może pojawić się niebezpieczna różnica zdań, a nawet rywalizacja w postrzeganiu zdarzeń międzynarodowych między obiema stronami. W tym miejscu warto zauważyć, iż Zjednoczone Królestwo raczej nie podporządkuje się unijnej polityce zagranicznej, chyba że będzie oddziaływać na jej formułowanie mimo statusu państwa trzeciego, w co jednak należy powątpiewać.

Choć rząd Jej Królewskiej Mości zapowiedział zdystansowanie się od prawa i instytucji UE, mechanizmy te wciąż zapewniają krajom członkowskim unikatowe wsparcie w zwalczaniu przestępczości i terroryzmu. W istocie Londyn zadeklarował oswobodzenie się z wpływu unijnych regulacji, które stanowią m.in. podstawę do dzielenia się cennymi informacjami wywiadowczymi. Należy podkreślić, że państwa trzecie nie mogą korzystać $\mathrm{z}$ dostępu do unijnych baz danych bez poddania się jurysdykcji Trybunału, tak kontestowanego przez zwolenników Brexitu. Zatem Bruksela nie zaakceptuje udziału Wielkiej

7 M. Matthijs, Europe after Brexit. A Less Perfect Union, „Foreign Affairs” 2017, January/February, s. 85. 
Brytanii we wspomnianych systemach informatycznych, jeśli ta wykazuje zamiar odrzucenia nadzoru organów wspólnoty. To z kolei może oznaczać swoistą fragmentaryzację bezpieczeństwa, prowadzącą do osłabienia obu podmiotów.

Aby podtrzymać możliwość korzystania z takich instytucji, jak Europejski Nakaz Aresztowania, Eurojust czy Europol, niezbędne będzie wdrożenie nowych podstaw prawnych współpracy, co uczyni aktualnym zagadnienie porozumienia, które ma zostać zawarte między brytyjskim rządem a Komisją Europejską. Nowe mechanizmy kooperacji będą musiały - co oczywiste - respektować suwerenność Zjednoczonego Królestwa, ponieważ zwolennicy tzw. twardego Brexitu mogą oponować wobec wprowadzenia rozwiązań, tworzących przestrzeń do aktywności gremiów UE na Wyspach. Instytucje te nie dadzą jednak obu stronom tyle, co ich obecne współdziałanie w ramach Obszaru Wolności, Bezpieczeństwa i Sprawiedliwości ${ }^{8}$.

Dziś Zjednoczone Królestwo awizuje konieczność podpisania nowego traktatu w zakresie bezpieczeństwa z państwami wspólnoty ${ }^{9}$. Podyktowane jest to zapewne pragnieniem utrzymania jego wpływu na unijną politykę zagraniczną, której - jako państwo trzecie - może stać się obiektem, by nie powiedzieć przedmiotem. Stanowi to gorzką konstatację, zważywszy na fakt, iż głównym motywem Brexitu była próba odzyskania kontroli Londynu nad własnym losem, który do tej pory uchodził za jednego ze współautorów unijnych działań zewnętrznych. Z pewnością istniejące modele kooperacji na linii wspólnota - państwo trzecie nie mogą stanowić punktu odniesienia dla Wielkiej Brytanii. Należy spodziewać się, że Londyn - jako dysponujący wyjątkowymi zasobami w skali całej Europy - będzie stroną dominującą w negocjacjach dotyczących nowego porozumienia w zakresie obronności. Zatem bezpieczeństwo - choć w sferze retorycznej bezwarunkowo chronione - może zostać sprowadzone to statusu zwykłego towaru w relacjach między sojusznikami. Wykorzystywanie tej sfery jako karty przetargowej w rokowaniach w przedmiocie wymiany handlowej między Wielką Brytanią a blokiem UE-27 doprowadziłoby jednak do obniżenia poziomu bezpieczeństwa obu stron, a zatem traktat o kooperacji militarnej winien być negocjowany osobno, by nie spowodować osłabienia pozycji tych aktorów na arenie międzynarodowej.

\section{Wpływ Brexitu na kierunki polityki obronnej wspólnoty}

Proces jednoczenia Europy - choć jego początkom towarzyszyła debata na temat wspólnej armii - obrał ostatecznie drogę współpracy w wybranych dziedzinach o charakterze gospodarczym. Nie ulega jednak wątpliwości, że integracja w zakresie węgla i stali miała wybitnie militarny kontekst, ponieważ dotyczyła kluczowych dla przemysłu obronnego

8 C. Mortera-Martinez, Plugging in the British: EU Justice and Home Affairs, „CER Policy brief” 2018, 25 May, http://cer.eu/publications/archive/policy-brief/2018/plugging-british-eu-justice-and-home-affairs [dostęp: 24.06.2018].

9 Prime Minister Theresa May's speech at the 2018 Munich Security Conference, 17.02.2018, https:// www.gov.uk/government/speeches/pm-speech-at-munich-security-conference-17-february-2018 [dostęp: 24.06.2018]. 
czynników produkcji. Owa kooperacja przyczyniła się wydatnie do budowy prosperity, potęgującej zasoby niezbędne do wzmocnienia obronności państw członkowskich. W tym sensie Unia sprzyjała postępowi gospodarczemu, stanowiącemu fundament do kreowania zdolności militarnych uczestników procesów integracyjnych. Z czasem Europejczycy zaczęli jednak bardziej odważnie spoglądać na instytucje powiązane bezpośrednio z bezpieczeństwem i obronnością. Wspólnota została ufundowana wprawdzie na przesłankach ekonomicznych, jednak jej nadrzędnym celem stało się zapewnienie pokoju w Europie. Skoro rezultatem procesów zjednoczeniowych była poprawa poziomu bezpieczeństwa, warto rozważyć, jaki wpływ na jego stan będą miały tendencje dekompozycyjne, których Brexit jest ewidentnym przejawem ${ }^{10}$.

W dobie reorientacji polityki amerykańskiej pod wpływem prezydentury D. Trumpa, uzupełnionej o wyjście Wielkiej Brytanii z Unii, odżywają dyskusje na temat budowy autonomicznych zdolności wojskowych wspólnoty, co może stanowić niebagatelne wyzwanie szczególnie dla państw tzw. wschodniej flanki, niezmiernie wyczulonych na wszelkie przeobrażenia architektury bezpieczeństwa kontynentu. Po zmianie na stanowisku prezydenta USA Europejczycy doszli do przekonania, iż winni oni przyjąć większą odpowiedzialność za obronność swego regionu. Donald Trump w istocie zakwestionował bezwarunkowość amerykańskiej pomocy sojusznikom, skoro w kampanii wyborczej uzależnił on zaangażowanie USA od wzrostu ich wydatków na zbrojenia. Do tej pory traktowano wspólną obronę Unii z nieskrywaną rezerwą, ponieważ była ona zakładnikiem polityki „NATO first”. Brexit połączony ze zmianą kierunków polityki USA może doprowadzić do odwrócenia tej tendencji.

Choć Wielka Brytania miała wpływ na genezę Wspólnej Polityki Zagranicznej i Bezpieczeństwa, obszar ten będzie funkcjonował z wyłączeniem Zjednoczonego Królestwa po jego formalnej secesji z Unii w 2019 roku. Brak dostępu do brytyjskich zdolności wojskowych i finansowych może uniemożliwić rozwój ambitnych projektów w dziedzinie strategicznych kompetencji wspólnoty, w tym perspektywy powołania armii europejskiej. Unijna dyplomacja niewątpliwie ucierpi na skutek utraty wsparcia kraju dysponującego globalną optyką, a wspólnotowe sankcje (np. wobec Federacji Rosyjskiej) mogą okazać się mniej skuteczne. Brexit spowoduje konieczność wypełnienia powyższej luki, co przy wciąż niewystarczającym poziomie nakładów na obronność państw członkowskich będzie niezwykle trudne. Ciężary ponoszone do tej pory przez Londyn będą musiały być bowiem rozdysponowane między poszczególnych uczestników bloku UE-27, jednak powstaje pytanie, czy pokryzysowa Europa dysponuje niezbędnymi ku temu zasobami, skoro większość krajów ma trudności, by osiągnąć pułap 2\% PKB wydatków na obronność.

Niewątpliwie w obecnej sytuacji trudno przekonać społeczeństwa do inwestowania w zbrojenia, więc jeszcze długo wydatki te nie powrócą do poziomu sprzed okresu turbulencji gospodarczych, a przecież i wówczas nie należały one do pozycji priorytetowych. Powyższe nie stanowi pozytywnego prognostyku na przyszłość, zwłaszcza w połączeniu z problemem braku efektywności w finansowaniu unijnych misji zagranicznych, opartych

${ }_{10}$ M. Wróblewska-Łysik, Europejska Strategia Globalna a możliwości wspótpracy Unii Europejskiej z NATO po szczycie w Warszawie, „Bezpieczeństwo Narodowe” 2016, nr 37-40, s. 72-77. 
na zasadzie „costs lie where they fall” "11, co nie zachęca państw członkowskich do udziału we wspólnych operacjach. Zgłaszane są zatem postulaty zmiany sposobu finansowania tej sfery poprzez specjalistyczne fundusze, gdyż rozwój zdolności obronnych nie może być opłacany z budżetu UE. Propozycje te budzą jednak wątpliwości szeregu państw wspólnoty, głównie ze względu na ich znaczące konsekwencje majątkowe, co czyni wspomniane inicjatywy mało popularnymi wśród obywateli.

Miejsce lidera unijnej obronności mogą zająć inne kraje, spośród których na czoło wysuwają się zwłaszcza Francja oraz Niemcy. Opuszczenie Unii przez jednego z największych sceptyków co do autonomicznych zdolności militarnych wspólnoty już skłoniło te państwa do ogłoszenia apelu o pogłębienie współpracy wojskowej w ramach tej organizacji ${ }^{12}$. Szczególnie Francja będzie zainteresowana przywództwem w tym obszarze z uwagi na posiadanie zasobów niezbędnych do prowadzenia misji zagranicznych, jak również dysponowanie stałym miejscem w Radzie Bezpieczeństwa ONZ. Jednak Paryż nie wykazuje takiego zrozumienia dla dylematów bezpieczeństwa krajów Europy Środkowo-Wschodniej, jakie stało się udziałem Wielkiej Brytanii. Powszechnie znana jest też francuska awersja do relacji transatlantyckich, a także swoistego rodzaju sympatia skierowana ku Rosji. Rezultatem Brexitu może być zatem pogłębienie współpracy niemiecko-francuskiej, oznaczającej w dalszej perspektywie silną dominację obu graczy w ramach formuły „militarnego Schengen"13 kosztem państw unijnych przywiązanych do współpracy w NATO. Należy oczekiwać pojawienia się przestrzeni do głębokich zmian, jednak wciąż nie wiadomo, czy będą one skutkować przeistoczeniem się Unii w wiarygodnego aktora na płaszczyźnie bezpieczeństwa. W interesie Polski oraz innych państw Unii, które uwypuklają naczelną rolę współpracy transatlantyckiej, leży taka idea wspólnej polityki obronnej, która polegałaby na bliskiej kooperacji z Sojuszem Północnoatlantyckim. Wprawdzie Niemcy, Francja, Włochy i Hiszpania już wyraziły zainteresowanie utworzeniem europejskiej awangardy w zakresie zbrojeń, ale nie można zaprzeczyć, że same instytucje nie wystarczą, jeśli nie zostaną one wypełnione niezbędną wolą polityczną ${ }^{14}$.

Jak się wydaje, w Unii nie uda się uzyskać powszechnej zgody na zasadniczą reformę Wspólnej Polityki Bezpieczeństwa i Obrony. Nie powinny zatem dziwić propozycje tych kilku państw, które wzywają do utworzenia europejskiego „rdzenia obronnego”, stanowiącego pogłębioną współpracę militarną w obrębie wąskiej grupy uczestników. W optyce wspomnianych krajów inicjatywy te stałyby się właściwą odpowiedzią na zagrożenia napływające z południowego sąsiedztwa Europy. Koncepcje „europejskiej unii obronnej”, zaopatrzonej w autonomiczne siły zbrojne, interweniujące w operacjach

11 Zasada samodzielnego finansowania udziału przez poszczególne państwa członkowskie, które pokrywają koszty wojskowe tam, gdzie one powstają.

12 J.-M. Ayrault, F.-W. Steinmeier, Ein starkes Europa in einer unsicheren Welt, https://www.auswaertigesamt.de/de/aussenpolitik/europa/160624-bm-am-fra-st/281698 [dostęp: 24.06.2018].

13 P. Gentiloni, EU needs 'Schengen for defense’, „Politico” 2016, 15 September, https://www.politico.eu/ article/italian-foreign-minister-eu-needs-schengen-for-defense-paolo-gentiloni-islamic-state-migrants-security/ [dostęp: 24.06.2018].

${ }^{14}$ A. Rettman, EU powers draft post-Brexit defence plan, „EU Observer” 2016, 13 October, https:// euobserver.com/foreign/135492 [dostęp: 24.06.2018]. 
zagranicznych zapowiadają powstanie „bezpieczeństwa wielu prędkości” na Starym Kontynencie. Dotychczasowa współpraca brytyjsko-francuska może być zatem zastąpiona przez francusko-niemiecką kooperację prowadzącą do renesansu inicjatyw torpedowanych dotychczas przez Brytyjczyków, takich jak powołanie do życia stałej współpracy strukturalnej w obszarze wojskowości ${ }^{15}$. W omawianym scenariuszu Polska znalazłaby się poza głównym nurtem unijnej współpracy, co jest szczególnie niebezpieczne w świecie pozbawionym strategicznych pewników. Co więcej, wektory polityki zagranicznej Unii mogą zostać przesunięte ku obszarom, które postrzegane są tradycyjnie przez Francję i Niemcy jako źródło problemów geopolitycznych naszego kontynentu, tj. Bliski Wschód i Afrykę, z oczywistym uszczerbkiem dla regionu Europy Wschodniej.

Niewykluczone, że te nowe inicjatywy powstaną poza strukturami Unii, z wyłączeniem Komisji i Parlamentu, które stoją na straży praw mniejszych państw członkowskich. Przykładowo niemiecki rząd zaproponował powołanie do życia rodzaju europejskiej rady bezpieczeństwa, składającej się z części państw unijnych, które jedynie konsultowałyby się ze wspólnymi instytucjami. Przypomina to swoisty „koncert mocarstw”, do którego kraje Europy Środkowo-Wschodniej raczej nie miałyby dostępu. W tym miejscu należy zauważyć, że bezpieczeństwo tzw. wschodniej flanki, w następstwie Brexitu, będzie wspierane przez misję wojskową tylko jednego państwa unijnego, tj. Republiki Federalnej Niemiec. Resztę bezpośrednio zaangażowanych krajów, na mocy postanowień warszawskiego szczytu NATO ${ }^{16}$, będą stanowiły państwa Sojuszu nienależące do wspólnoty (tj. Kanada, USA i Wielka Brytania).

Skutkiem odejścia Zjednoczonego Królestwa od projektu europejskiego może być też wzrost znaczenia bilateralnych inicjatyw, podejmowanych przez uczestników wspólnoty euroatlantyckiej, kosztem osłabienia dynamiki współpracy wielostronnej w ramach NATO i UE. Dziś przykładowo Polska bardziej preferuje dokonywanie zakupów zbrojeniowych w Stanach Zjednoczonych aniżeli wspieranie rozwoju przemysłu obronnego w Europie. W istocie państwa tzw. wschodniej flanki wolałyby zawrzeć dwustronne porozumienia $\mathrm{z}$ administracją D. Trumpa, w myśl których wojska amerykańskie stale stacjonowałyby w regionie, niż inwestować we wspólne siły interwencyjne UE. Nic zatem dziwnego, iż w przypadku braku zdecydowanych działań ze strony wspólnoty istnieje ryzyko całkowitego wygaszenia Wspólnej Polityki Bezpieczeństwa i Obrony na rzecz budowy autonomicznego rdzenia militarnego Unii lub zawierania bilateralnych umów w sprawie bezpieczeństwa. Niezwykle wymowny jest fakt, iż spotkanie liderów Francji, Niemiec i Włoch poświęcone przyszłości UE po Brexicie odbyło się na pokładzie włoskiego lotniskowca noszącego nazwę „Giuseppe Garibaldi”, który bierze udział w unijnej misji wymierzonej w przemytników migrantów z Afryki Północnej. Powyższe oznaczać może perspektywę ulokowania strategicznego zainteresowania wspólnoty w obszarze Morza Śródziemnego z pominięciem regionu wschodnioeuropejskiego. Ponadto zdarzenie to

15 A. Barluet, La feuille de route franco-allemande pour relancer l'Europe de la défense, „Le Figaro” 2016, 11 September, http://www.lefigaro.fr/international/2016/09/11/01003-20160911ARTFIG00140-lafeuille-de-route-franco-allemande-pour-relancer-l-europe-de-la-defense.php [dostęp: 24.06.2018].

${ }^{16}$ Międzynarodowy szczyt państw członkowskich Sojuszu Północnoatlantyckiego na szczeblu szefów państw i rządów zorganizowany w dniach 8-9 lipca 2016 roku w Warszawie. 
wskazuje na tendencję do opierania jej przyszłości na zasobach państw narodowych, ponieważ postać Garibaldiego pozostaje raczej symbolem Europy ojczyzn aniżeli zapowiedzią ukonstytuowania się silnego ponadnarodowego polity.

$\mathrm{Z}$ pewnością nie można oczekiwać szybkiego przełomu w dziedzinie europejskiej obronności, do czego niezbędne są nowe inicjatywy, by uzupełnić ewidentne luki w zdolnościach wojskowych Unii, uniemożliwiające projekcję siły w operacjach międzynarodowych. Wymaga to jednak wygenerowania zaufania do nowych form kooperacji, których tworzenie może zająć dekady. By myśleć o powstaniu operatywnych sił zbrojnych wspólnoty, państwa członkowskie będą musiały inwestować w narodowe zdolności wojskowe, przy czym warto podkreślić, iż zbrojenia te pozostają niepopularne politycznie, gdyż charakteryzują się potrzebą znaczących nakładów finansowych. Obecnie w Europie jest wiele niekompatybilnych systemów militarnych, przemysły obronne są mało konkurencyjne, a pieniądze wydawane są w sposób nieefektywny. Nadal kraje członkowskie preferują produkty narodowe, więc polityka zamówień nie jest prawdziwie europejska. A tylko Wielka Brytania, której wkrótce zabraknie, opowiadała się za wolnym rynkiem zbrojeniowym, nadającym impuls współpracy wojskowej.

\section{Podsumowanie}

Pobrexitowa reforma europejskiej polityki obronnej może skutkować utworzeniem swoistego rdzenia militarnego Unii, prowadzącego do „bezpieczeństwa wielu prędkości” na Starym Kontynencie. Będzie to stanowić niebagatelne wyzwanie dla tych krajów wspólnoty, które opowiadają się za utrzymaniem inkluzywnej i zrównoważonej współpracy obronnej, z zachowaniem kluczowej roli NATO jako gwaranta bezpieczeństwa europejskiego. Niewątpliwie w Unii pojawi się nowa struktura pogłębionej integracji, która mimo ograniczonych zasobów będzie miała istotne znaczenie polityczne. Z pewnością wymagała będzie ona odpowiedzi na kluczowe pytania o charakter relacji transatlantyckich, a także rolę Stanów Zjednoczonych i Wielkiej Brytanii w polityce bezpieczeństwa kontynentu. W następstwie Brexitu istnieje ryzyko rozczłonkowania współpracy wielostronnej na rzecz relacji bilateralnych ze szkodą dla wspólnego bezpieczeństwa, które jest przecież niepodzielne. Po wystąpieniu Wielkiej Brytanii z Unii zostaną bowiem odmrożone inicjatywy w sferze militarnej, mające na celu budowę autonomicznych zdolności obronnych wspólnoty w wąskim kręgu wybranych krajów członkowskich. W aktualnej sytuacji faktyczna realizacja powyższych projektów wydaje się mało realistyczna z uwagi na niechęć do ponoszenia nakładów na zbrojenia przez uczestników projektu europejskiego. Jednak w dalszej perspektywie inicjatywy te mogą zostać twórczo rozwinięte, skutkując powstaniem odrębnych od NATO kompetencji militarnych UE, z osobnym budżetem oraz własną polityką przemysłową, które będą uprzywilejowywać „twardy rdzeń” integracji kosztem państw peryferyjnych. Powyższe oznacza konieczność poszukiwania nowych koncepcji teoretycznych, bardziej adekwatnie opisujących architekturę bezpieczeństwa Starego Kontynentu, jaka wyłoni się w rezultacie tendencji dekompozycyjnych Unii, których Brexit jest niewątpliwie przejawem. 


\section{Bibliografia}

Ayrault J.-M., Steinmeier F.-W., Ein starkes Europa in einer unsicheren Welt, https://www.auswaertiges-amt.de/de/aussenpolitik/europa/160624-bm-am-fra-st/281698 [dostęp: 24.06.2018].

Barluet A., La feuille de route franco-allemande pour relancer l'Europe de la défense, „Le Figaro", 11.09.2016, http:/www.lefigaro.fr/international/2016/09/11/01003-20160911ARTFIG00140-la-feuille-de-route-franco-allemande-pour-relancer-l-europe-de-la-defense.php [dostęp: 24.06.2018].

Borkowski P.J., Polityczne teorie integracji międzynarodowej, Centrum Doradztwa i Informacji Difin, Warszawa 2007.

Burke E., Brexit and the threat to Northern Ireland, „CER Bulletin” 2017, Issue 115, August/September, http://www.cer.eu/sites/default/files/bulletin_115_eb_article1.pdf [dostęp: 24.06.2018].

Gentiloni P., EU needs 'Schengen for defense’, „Politico”, 15.09.2016, https://www.politico. eu/article/italian-foreign-minister-eu-needs-schengen-for-defense-paolo-gentiloni-islamicstate-migrants-security/ [dostęp: 24.06.2018].

Goodwin M., Milazzo C., Taking back control? Investigating the role of immigration in the 2016 vote for Brexit, „The British Journal of Political Science and International Relations” 2017, Vol. 19, Issue 3.

MacDowall A., Brexit Raises Economic and Security Fears in Central and Eastern Europe, „World Politics Review” 2016, 21 June, https://www.worldpoliticsreview.com/articles/19134/ brexit-raises-economic-and-security-fears-in-central-and-eastern-europe [dostęp: 24.06.2018].

Matthijs M., Europe after Brexit. A Less Perfect Union, „Foreign Affairs” 2017, January/ February.

Mortera-Martinez C., Plugging in the British: EU Justice and Home Affairs, „CER Policy brief" 2018, 25 May, http://cer.eu/publications/archive/policy-brief/2018/plugging-british-eu-justice-and-home-affairs [dostęp: 24.06.2018].

Oltermann P., Theresa May wants new security treaty with EU next year, „The Guardian” 2018, 17 February, https://www.theguardian.com/politics/2018/feb/17/theresa-may-wantsnew-security-treaty-with-eu-next-year [dostęp: 24.06.2018].

Prime Minister Theresa May's speech at the 2018 Munich Security Conference, 17.02.2018, https://www.gov.uk/government/speeches/pm-speech-at-munich-security-conference-17february-2018 [dostęp: 24.06.2018].

Rettman A., EU powers draft post-Brexit defence plan, „EU Observer” 2016, 13 October, https://euobserver.com/foreign/135492 [dostęp: 24.06.2018].

Wróblewska-Łysik M., Europejska Strategia Globalna a możliwości współpracy Unii Europejskiej z NATO po szczycie w Warszawie, „Bezpieczeństwo Narodowe” 2016, nr 37-40. 


\section{Streszczenie}

(Nie)Bezpieczna Europa po Brexicie?

Wystąpienie Zjednoczonego Królestwa ze Wspólnoty Europejskiej może wywrzeć niebagatelny wpływ na bezpieczeństwo Europy zarówno na płaszczyźnie polityczno-gospodarczej, jak i militarnej. Szeroko pojęte zasoby Unii Europejskiej ulegną niewątpliwie uszczupleniu na skutek secesji Wielkiej Brytanii z tej organizacji, choć z drugiej strony wspólnota odzyska elementarną sterowność w dziedzinie bardziej zaawansowanych form współpracy na niwie obronności z uwagi na wystąpienie z jej szeregów aktora, który dotychczas odgrywał rolę jednego z najzagorzalszych przeciwników autonomii strategicznej Unii. Powyższe skłania do poszukiwania nowych koncepcji analitycznych oraz modeli teoretycznych opisujących bezpieczeństwo Europy, które mogą objawić się w następstwie Brexitu. Będą one miały fundamentalne znaczenie dla krajów będących obecnie beneficjentami pokoju i stabilności na Starym Kontynencie, w tym Polski.

Słowa kluczowe: Brexit, bezpieczeństwo międzynarodowe, Unia Europejska

\section{Summary}

\section{(Un)Secured Europe after Brexit?}

The withdrawal of the United Kingdom from the European Union may have a significant impact on Europe's political, economic and military security. The resources of the European Union will undoubtedly be reduced as a result of Great Britain leaving. However, the European Union will gain more sophisticated forms of defence cooperation, due to the departure of an actor who has been one of the most obstinate opponents of the Union's strategic autonomy. This mandates the search for new analytical concepts and theoretical models to describe European security that may emerge as a result of Brexit. These will have fundamental significance for the countries currently benefiting from peace and stability in Europe, including Poland.

Keywords: Brexit, international security, the European Union 


\section{Bezpieczeństwo biologiczne populacji. Zdrowie publiczne a Państwowa Inspekcja Sanitarna jako najważniejsza instytucja sfery zdrowia publicznego}

\section{Wstęp}

W dynamicznym świecie pierwszych dekad XXI wieku, gdzie większą część Produktu Krajowego Brutto generują usługi, a podstawą działania staje się szybkość reakcji, wzrasta ciężar gatunkowy sfery usług niematerialnych. Staje się ona jednym z istotnych elementów stosunków społecznych i wzrostu gospodarczego. W społeczeństwie ponowoczesnym podstawowe dla tradycji klasycznej źródła bogactwa - ziemię, kapitał i pracę fizyczną, zastępują systemy funkcjonujące w oparciu o elementy niematerialne - usługi, wiedzę i innowacyjność. Gdyby uogólnić znane prawo Engla, iż w miarę wzrostu dochodów maleją względnie wydatki na żywność, to można powiedzieć, że następuje względna marginalizacja fizycznych przedmiotów konsumpcji. Głównym źródłem bogactwa są produkty o charakterze niematerialnym, niemożliwe do magazynowania i niemożliwe do prostego standaryzowania. Poziom ich jakości ocenia się dopiero w trakcie spożycia. Jednym z najistotniejszych elementów tak określonego continuum jest sfera bezpieczeństwa indywidualnego i zbiorowego. W tej sferze, jako najważniejszej dla każdego człowieka, zawierają się zagadnienia zdrowia - zarówno indywidualnego, każdej osoby, jak i publicznego, dotyczącego całych populacji. Można je określić wspólnym mianem biobezpieczeństwa. 
Celem artykułu jest analiza zadań i sposobu funkcjonowania Państwowej Inspekcji Sanitarnej ${ }^{1}$ jako najważniejszej instytucji funkcjonującej w Polsce w sferze biobezpieczeństwa ludności - zdrowia publicznego. Pozycja i działania Inspekcji omówione zostaną na tle historii działań odnoszących się do bezpieczeństwa biologicznego ludzkości jako gatunku. Przeanalizowane będą wybrane aspekty teoretyczne związane ze zdrowiem publicznym. Hipotezą badawczą jest twierdzenie, że badana instytucja wypełnia swoją misję w niespójnych uwarunkowaniach organizacyjnych i w bardzo trudnych warunkach ekonomicznych.

\section{Biowładza - biobezpieczeństwo populacji}

Polityka od początku istnienia miała związki z życiem. Życie w sensie biologicznym było i jest ramą działań politycznych. Począwszy od polityki agrarnej starożytnych imperiów, poprzez działania sanitarno-higieniczne Rzymu, aż do zalecanych przez Platona działań eugenicznych, wszystko było biopolityką. Hobbes umieścił życie w centrum polityki, uznając, że do jego ochrony poddani powołali państwo ${ }^{2}$.

Podstawowe biologiczne problemy egzystencjalne, z jakimi borykała się ludzkość przez tysiące lat, stanowiły wypadkową działania sił natury. Głód i choroby były skutkiem niemożliwych do zaplanowania i zrozumienia żywiołowych wydarzeń, wśród których najważniejszym śmiertelnym przeciwnikiem były zarazy ${ }^{3}$. Zupełnie niezrozumiałe dla starożytnych i średniowiecznych ludzi (podstawy bakteriologii stworzył Ludwik Pasteur w XIX wieku) epidemie mordowały w przeszłości dziesiątki milionów osób ${ }^{4}$. Znana pandemia średniowieczna - czarna ospa - pochłonęła około jednej czwartej populacji Eurazji. XX-wieczna epidemia grypy „hiszpanki” zabrała 50-100 milionów osób 5 .

W starożytności i średniowieczu podtrzymanie życia pojedynczych osób (i rodzin) oraz ich reprodukcja należały do sfery prywatnej. Nowoczesne społeczeństwa zachodnie od początku XVIII wieku uznały fakt, że rodzaj ludzki jest gatunkiem biologicznym. Systematycznie i programowo zaczęto wprowadzać mechanizmy prowadzące do tego, że określone cechy biologiczne gatunku włączono w obszar polityki. Stało się to przedmiotem strategii władzy. Tak rozumianą politykę społeczną wobec gatunku biologicznego nazwano

\footnotetext{
1 W dalszej części używana jest też zamiennie nazwa PIS oraz Inspekcja.

2 R. Esposito, Pojęcia polityczne. Wspólnota, immunizacja, biopolityka, Towarzystwo Autorów i Wydawców Prac Naukowych Universitas, Kraków 2015, s. 112.

${ }_{3}$ Poza takimi katastrofami, jak wybuch superwulkanu Toba na Sumatrze sprzed około 74 tysięcy lat, który był najsilniejszym wybuchem w czwartorzędzie i zmniejszył populację całego gatunku ludzkiego do około 10 tysięcy. Zob. W. Behringer, Kulturgeschichte des Klimas, na podstawie wydania czeskiego: Kulturni dějiny klimatu, Nakladatelství Paseka, Praha-Litomyšl 2010.

${ }^{4}$ Ciekawostką jest fakt, że mordercze epidemie Thomas Malthus uznał za zjawisko pożądane, chroniące dynamicznie rozrastającą się ilościowo ludzkość przed głodem. T. Malhtus, Prawo ludności, Wydawnictwo De Agostini, Ediciones Altaya Polska, Warszawa 2003.

5 L.B. Brydak, Grypa: pandemia grypy - mit czy realne zagrożenie, Oficyna Wydawnicza Rytm, Warszawa 2008, s.7.
} 
biowładzą ${ }^{6}$. Suwerenna władza, sprawowana w granicach określonego terytorium, wdraża rozwiązania bezpieczeństwa dotyczące:

- terytorium (przestrzeń),

- dyscypliny (pojedyncze osoby - ciała),

- bezpieczeństwa biologicznego (populacja) ${ }^{7}$.

Konsekwencją rozwoju modernistycznego i postmodernistycznego jest systematyczny wzrost bezpieczeństwa biologicznego zarówno poszczególnych osób, jak i całej populacji. Biotechnologie (w szczególności szczepienia) i polityki publiczne (ważnym elementem jest tu ochrona zdrowia publicznego) spowodowały, że w ostatnich dziesięcioleciach liczba epidemii i skala ich następstw stopniowo, znacząco się zmniejszała. SARS ${ }^{8}$, który wzbudził panikę, ostatecznie pochłonął mniej niż tysiąc istnień ludzkich. Ebola, zdaniem Światowej Organizacji Zdrowia (World Health Organization - WHO) najpoważniejsza współczesna sytuacja kryzysowa w obszarze zdrowia publicznego, zakończyła się śmiercią 11 tysięcy osób (przy 30 tysiącach zarażonych). Niesłychanie trudna do zrozumienia i opanowania choroba AIDS $^{9}$ od początku lat 80 . XX wieku zabiła ponad 30 milionów ludzi.

Wbrew niektórym autorom, twierdzącym, że przednowożytne władze były wobec katastrof epidemii bezradne i że - poza zbiorowymi modłami i procesjami - nie znały żadnych sposobów powstrzymywania epidemii ${ }^{10}$, już od czasów biblijnych istniały zorganizowane metody walki o redukowanie skutków i kontrolowanie przestrzenne epidemii. Można przywołać przykłady strategii biobezpieczeństwa stosowanych już w czasach biblijnych i w średniowieczu:

1. Podział binarny (zarażeni-zdrowi, wykluczenia, oznaczanie wykluczonych) - rozwiązanie dyscyplinujące, skierowane ku pojedynczym ciałom. Już w czasach biblijnych stosowano wykluczenia dotyczące chorych zakaźnie, zmuszające do oznakowania i izolacji: „Przez cały czas trwania tej choroby [trędowaty] będzie nieczysty. Samotnie mieszkać będzie, jego mieszkanie będzie poza obozem" "11. Także w średniowieczu stosowano kwarantanny, oznakowania i wykluczenia. Średniowieczne przysłowie mówi: „Kto ma parchy, nie powinien zdejmować czapki""12.

2. Parcelacja terytorialna (epidemie, kwarantanny) - rozwiązanie mieszane: dyscyplinujące, skierowane ku pojedynczym ciałom oraz zapobiegawcze, skierowane ku bezpieczeństwu populacji. Rozwiązanie starożytne opisuje IV Księga Mojżeszowa: „Usuniecie zarówno mężczyznę, jak kobietę poza obóz, usuniecie ich, aby nie zanieczyścili swojego obozu [...]. I uczynili tak synowie izraelscy" "13. W średniowieczu wykluczanie trędowatych

\footnotetext{
${ }^{6}$ M. Foucault, Bezpieczeństwo, terytorium, populacja, PWN, Warszawa 2010, s. 35 i nast. Michel Foucault jako pierwszy wprowadził to pojęcie, obecnie szerzej używane.

7 Tamże, s. 35.

${ }^{8}$ Zespół ciężkiej niewydolności oddechowej, rodzaj zapalenia płuc.

9 Zespół nabytego niedoboru odporności, zakażenie wirusem HIV.

10 Y.N. Harari, Homo deus. Krótka historia jutra, Wydawnictwo Literackie, Kraków 2018, s. 13.

11 Biblia to jest pismo święte starego i nowego testamentu, Brytyjskie i Zagraniczne Towarzystwo Biblijne, Warszawa 1975, III Mojż. 13, 45.

12 J. Huizinga, Jesień średniowiecza, t II, PIW, Warszawa 1967, s. 101.

13 Biblia..., dz. cyt., IV Mojż. 5, 3-4.
} 
odbywało się za pomocą regulacji prawnych, przy jednoczesnym zachowaniu procedur religijno-rytualnych.

Rozwiązania nowożytne dodatkowo skorzystały ze zdobyczy nauki. Stopniowo wprowadzono system zapobiegawczy (szczepienia, technologie bezpieczeństwa), czyli rozwiązanie technologiczne modyfikujące biologię gatunku, eliminujące przypadkowość, skierowane ku bezpieczeństwu całej populacji.

Pierwsze dwa działania leżą w obszarze szeroko rozumianego zarządzania. Ciekawym przykładem pozytywnego efektu zarządczego rozwiązania dyscyplinującego, poczynionego jeszcze w czasach przed Pasteurem, są działania Ignacego Filipa Semmelweisa (1818-1865) w dziedzinie zakażeń szpitalnych. Przeprowadził on w wiedeńskim szpitalu w latach 1841-1849 obserwacje i analizy statystyczne. Praktycznym zastosowaniem były skodyfikowane procedury higieniczne. Pozwoliły one, jeszcze bez wiedzy o bakteriach i antybiotykach, zmniejszyć umieralność kobiet na gorączkę popołogową (rodzaj sepsy) $\mathrm{z}$ ponad $30 \%$ do $2-4 \%{ }^{14}$. Eksperymenty $\mathrm{z}$ technologiami bezpieczeństwa podjęto $\mathrm{w}$ samym końcu XVIII wieku. W latach 1796-1798 lekarz praktyk Edward Jenner wyłącznie na podstawie obserwacji odkrył zjawisko odporności krzyżowej. W ślad za tym przeprowadził pierwsze wakcynacje (szczepienia). Pomimo oporów, obserwując skuteczność metody Jennera, podjęto w wielu krajach akcje wakcynacji ${ }^{15}$.

We współczesnych społeczeństwach biobezpieczeństwo zapewnić ma stosowanie w szerokim zakresie zdobyczy nauk (w tym medycyny, biotechnologii, technologii medycznej, inżynierii) oraz stworzenie systemu instytucji zapewniających ochronę zdrowia (bezpieczeństwo osobnicze), jak też ochronę zdrowia publicznego (bezpieczeństwo całych populacji). Działania podejmowane przez władzę są organizacyjnie tożsame z przywołanymi już metodami biowładzy epok wcześniejszych. Dotyczą więc terytorium, pojedynczych osób oraz społeczeństw. Najważniejszą różnicą jest poziom rozwiązań technologicznych dotyczących osób (technologie biomedyczne, inżynieryjne, poziom nauki medycyny) oraz poziom działań dotyczących, ogólnie mówiąc, modyfikowania biologii gatunku, czyli wspomnianej już eliminacji przypadkowości. Składają się na nie coraz lepsze szczepionki, coraz sprawniejsze i szybsze systemy reagowania na zagrożenia. Przykładowym efektem może tutaj być eradykacja kilku groźnych chorób, w tym na przykład ospy prawdziwej ${ }^{16}$ czy poliomyelitis. Ospa została ostatecznie zwalczona w 1979 roku. Program eradykacji poliomyelitis koordynowany przez WHO i realizowany we wszystkich krajach ma szanse odnieść sukces. Do tej pory nie udało się dokonać eradykacji polio jeszcze tylko w trzech krajach - Nigerii, Pakistanie i Afganistanie.

Poważne, nowe rodzaje zagrożeń stanowią współcześnie:

1. Wyczerpywanie się możliwości leczniczych znanych antybiotyków; WHO ogłosiła już wejście ludzkości w erę postantybiotykową.

14 J. Michalak, Zakażenia szpitalne jako problem zarządczy i miernik jakości opieki w szpitalu, [w:] A. Denys, Zakażenia szpitalne. Wybrane zagadnienia, Wolters Kluwer Polska, Warszawa 2012, s. 290-291.

15 W. Magdzik, Naruszewicz-Lesiuk D., Zieliński A., Wakcynologia, Wydawnictwo $\alpha$-medica press, Bielsko-Biała 2007, s. 19.

16 Tamże, s. 438. 
2. Potencjalna, nowa, nieznana jeszcze choroba, która może doprowadzić do pandemii; przewidywana przez wielu naukowców (może to się kojarzyć z hipotezą Gai wysuniętą w latach 70. XX wieku przez Jamesa Lovelocka: Ziemia jako homeostat samoczynnie regulujący populację).

3. Ruchy antyszczepionkowe, które w chwili obecnej mają szansę doprowadzić do zagrożenia epidemią na przykład odry w Europie.

\section{Ochrona zdrowia, ochrona zdrowia publicznego}

Pojęcia zdrowia i choroby są podstawą dla praktyki leczniczej oraz organizacji ochrony zdrowia. Ocenia się, że istnieje około 120 definicji zdrowia bazujących na różnych płaszczyznach ${ }^{17}$. Wpływ na rozumienie pojęcia zdrowia i choroby mają poziom nauki, czynniki społeczno-kulturowe, a nawet systemy społeczno-polityczno-ekonomiczne. Jedną z powszechnie używanych (mimo wielu krytyk) jest przyjęta przez WHO tzw. holistyczna i pozytywna definicja zdrowia, która ujmuje je jako: „kompletny, fizyczny, psychiczny i społeczny dobrostan człowieka, a nie tylko brak choroby lub kalectwa". Jest to definicja biologiczno-funkcjonalna, wywodząca się z nurtu hipokratejskiego ${ }^{18}$. Również zdrowie publiczne jako podstawowy element bezpieczeństwa populacji jest definiowane na wiele sposobów. Do dziś aktualna i powszechnie używana jest definicja, którą podał Charles Edward Amory Winslow (1877-1957), pierwszy kierownik Zakładu Zdrowia Publicznego w Yale School of Epidemiology \& Public Health. Definicja pochodzi z 1920 roku: „Zdrowie publiczne to nauka i sztuka zapobiegania chorobom, wydłużania życia oraz promowania zdrowia fizycznego i sprawności poprzez zorganizowane wysiłki społeczeństwa mające na celu higienizację środowiska, zwalczanie zakażeń występujących w społecznościach, edukację jednostek odnośnie zasad higieny osobistej, organizację świadczeń lekarskich i pielęgniarskich mających na celu wczesną diagnozę oraz profilaktycznie ukierunkowane leczenie oraz rozwój mechanizmów społecznych, które zapewnią każdej jednostce w społeczeństwie standard życia właściwy dla utrzymania zdrowia"19.

W makrosystemie ochrony zdrowia miejsce zdrowia publicznego w relacji do kosztów przedstawione został na rysunku 1 .

17 J. Domaradzki, O definicjach ochrony zdrowia i choroby, „Folia Medica Lodziensa” 2013, nr 40/1, http://yadda.icm.edu.pl/yadda/element/bwmeta1.element.psjd-277d74778-0030-47a4-b518-3ecc6fa630b9 [dostęp: 10.05.2018].

18 Tamże.

${ }_{19}$ M. Kowalska, Cele i zadania zdrowia publicznego, Katedra i Zakład Epidemiologii, Śląski Uniwersytet Medyczny w Katowicach, http://epidemiologia.sum.edu.pl/wp-content/uploads/2012/10/Seminarium-1.pdf [dostęp: 10.05.2018]. 


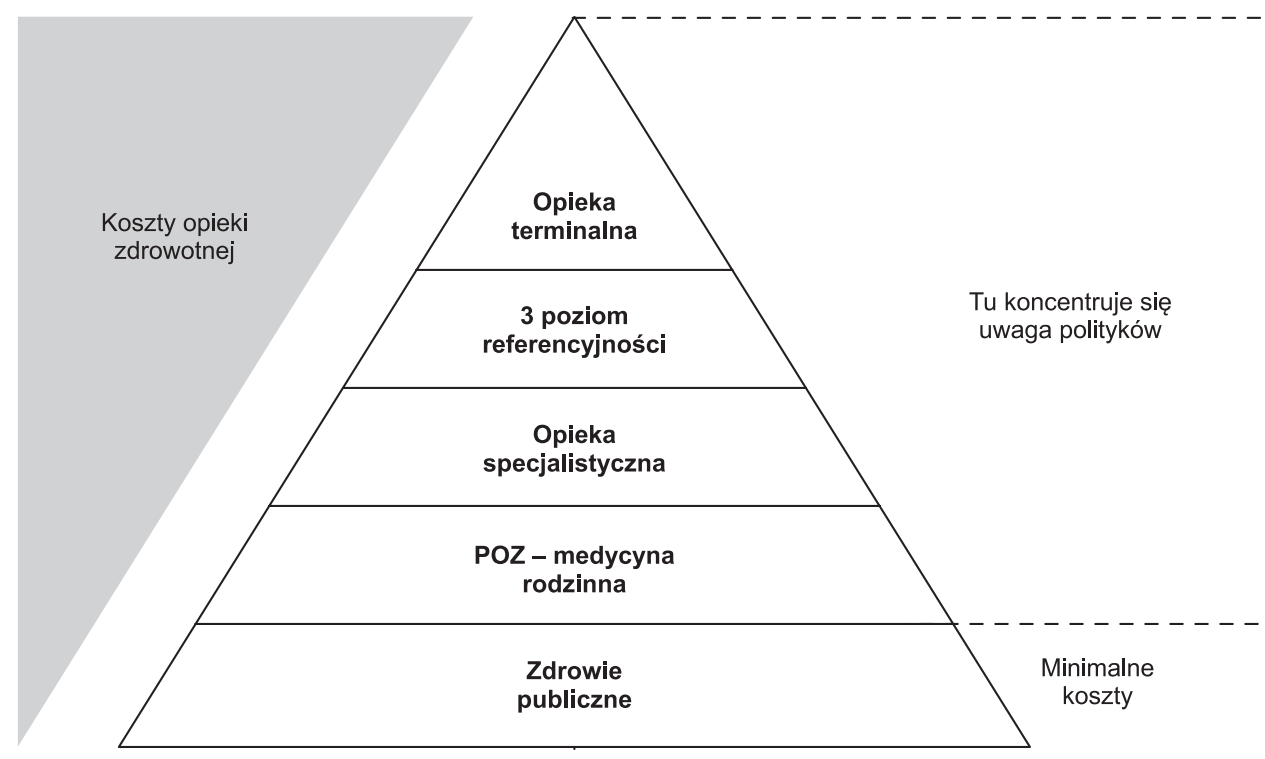

Rysunek 1. Makrosystem ochrony zdrowia

Źródło: M. Kowalska, dz. cyt.

Obraz wskazuje na proporcjonalnie minimalne koszty działań w obszarze zdrowia publicznego w stosunku do kosztów medycyny naprawczej (wyższe poziomy trójkąta). Stan taki, który pozornie wskazywałby na potrzebę inwestowania (szeroko rozumianego) w działania z dziedziny zdrowia publicznego jest ujemnie skorelowany z koncentracją zainteresowania politycznego. Można dodać, że medycyna naprawcza koncentruje też uwagę mediów i społeczeństwa. Działania instytucji zdrowia publicznego pozostają na marginesie zainteresowania politycznego i publicznego. Sytuacja taka jest zalążkiem wielu prawnych, organizacyjnych i ekonomicznych kłopotów instytucji działających w sferze biobezpieczeństwa populacji.

Biorąc pod uwagę możliwości działania, należy skonfrontować pozycję zdrowia publicznego z ideą pól zdrowia określonych w latach 70. XX wieku przez Marca Lalonde’a, ministra zdrowia Kanady. Koncepcja przygotowana była pod kątem możliwych zastosowań w polityce zdrowotnej ${ }^{20}$. Miała służyć racjonalizacji procesu decyzyjnego władz publicznych w sprawach dotyczących zdrowia. Została zaprojektowana tak, aby umożliwić scalenie wielu rozproszonych informacji w sposób zgodny z ustaleniami naukowymi i jednocześnie prosty do uwzględnienia w publicznych dyskusjach oraz dający się zastosować w procesach decyzyjnych. Tak więc wstępnie oznaczono czynniki wpływające na

${ }^{20}$ Być może jako prekursorską koncepcję pola zachowań potraktować można poglądy markiza de Sade’a o wpływie zachowań seksualnych na zdrowie. Twierdził on, że „Niemal wszystkie kobiety niewinne umierają młodo bądź gdy młodość przemija, popadają w szaleństwo, zostają kalekami, są słabowite”. Zob. W.C. Włodarczyk, Uwagi o modelach warunkowań i zróżnicowań stanu zdrowia, [w:] Model oceny wptywu regulacji prawnych $i$ instytucjonalnych na zdrowie, Narodowy Instytut Zdrowia Publicznego - Państwowy Zakład Higieny, Kraków-Warszawa 2017, s. 62. 
zdrowie: styl życia, środowisko, organizację ochrony zdrowia (przyznając im wartości procentowe odpowiednio - 75, 20,5) ${ }^{21}$. Uznano, że idea pól zdrowia otwiera nowe perspektywy badawcze oraz nowe perspektywy działań w obszarach dotychczas zaniedbanych. Koncepcję stopniowo rozwijano. Po czterdziestu latach pola oraz ich wartości określa się tak jak zaprezentowano na rysunku 2.

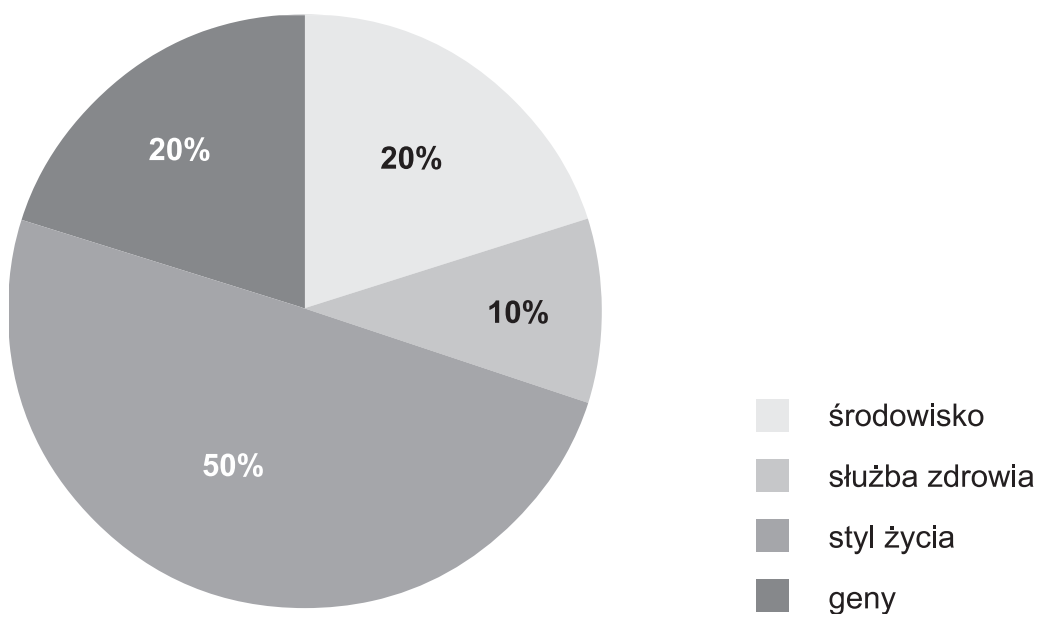

Rysuenk 2. Pola zdrowia

Źródło: opracowanie na podstawie M. Kowalska, dz. cyt.

Zestawiając dane zawarte w obu powyższych wykresach, można zauważyć, że w dziedzinie ochrony biologicznej populacji, zdrowie publiczne jest dziedziną najmniej kosztochłonną i najmniej interesującą dla polityków. Jednocześnie pola zdrowia zawierają wskazówkę, jak bardzo istotne są działania z zakresu zdrowia publicznego. Obszary najważniejsze, to jest styl życia i środowisko, są dziedziną pracy instytucji zdrowia publicznego ${ }^{22}$.

\section{Państwowa Inspekcja Sanitarna - misja i obrazy metaforyczne organizacji}

Dokonując analizy historycznej nowożytnej cywilizacji Jürgen Habermas stwierdził, że „Sektor usług publicznych siłą rzeczy się rozszerza [...]. Obok publicznych kosztów produkcji prywatnej powstają, proporcjonalnie do wzrostu siły nabywczej szerokich

${ }^{21}$ M. Lalonde, A New Perspective On The Health Of Canadians, a working document, http://www.phacaspc.gc.ca/ph-sp/pdf/perspect-eng.pdf [dostęp: 5.05.2018].

${ }^{22}$ Współcześnie funkcjonują kolejne modele uwarunkowań stanu zdrowia. Najczęściej powoływany jest model Gorana Dahlgrena i Margaret Whitehead. Istotna z punktu widzenia polityki jest wersja modelu przyjęta przez WHO, gdzie operuje się pojęciem rozkładu zdrowia i dobrostanu, a nie po prostu zdrowia. W.C. Włodarczyk, dz. cyt., s. 72. 
mas, publiczne koszty prywatnej konsumpcji ${ }^{23}$. W systemie instytucji ochrony zdrowia publicznego w Polsce podstawową rolę odgrywa Państwowa Inspekcja Sanitarna. Jej powstanie, zadania i rozwój są ilustracją tej tezy Habermasa. Podejmując próbę opisu dzisiejszego stanu struktury pod nazwą Państwowa Inspekcja Sanitarna, należy odnieść się do zdefiniowanych przez naukę jej celów. Zadania inspekcji sanitarnej z perspektywy czynnościowej ${ }^{24}$ i zakres działania można przedstawić następująco:

- monitorowanie stanu zdrowia publicznego oraz określenie potrzeb zdrowotnych populacji,

- identyfikacja i zwalczanie czynników ryzyka zdrowotnego,

- zapobieganie rozprzestrzenianiu się chorób, zwłaszcza zakaźnych,

- zapewnienie nadzoru epidemiologicznego i kontroli zagrożeń środowiska,

- promowanie zdrowego stylu życia wszystkich obywateli, w tym w szczególności dzieci i młodzieży,

- doskonalenie zawodowe lekarzy i innego personelu medycznego zgodnie z wymogami współczesnej wiedzy medycznej,

- obserwacja istniejących i inicjowanie nowych regulacji prawnych, dotyczących systemu ochrony zdrowia publicznego,

- dozorowanie jakości świadczeń medycznych,

- ocena sytuacji zdrowotnej kraju i poszczególnych regionów (województw),

- analiza pojawiających się nowych wyzwań i zagrożeń wynikających z globalnych procesów biologicznych (w tym mutacje i rozprzestrzenianie się mikroorganizmów), geofizycznych (w szczególności konsekwencje zmian klimatycznych), politycznych (bioterroryzm) i technologicznych (nowe rodzaje broni, szybkość i konsekwencje obiegu informacji, szlaki i technologie fizycznej komunikacji ${ }^{25}$.

Formalno-prawne ramy działania PIS w pierwszej dekadzie XXI wieku wyznacza cały czas wielokrotnie zmieniana Ustawa z dnia 14 marca 1985 r. o Państwowej Inspekcji Sanitarnej ${ }^{26}$.

23 J. Habermas, Strukturalne przeobrażenia sfery publicznej, PWN, Warszawa 2007, s. 288.

${ }^{24} \mathrm{Na}$ temat perspektyw postrzegania organizacji: A. Adamik, Nauka o organizacji, Wolters Kluwer business, Warszawa 2013, s. 34-39.

${ }_{25}$ Zestawienie własne sporządzone na podstawie analizy przepisów prawa rangi ustawowej oraz aktów wykonawczych, jak również analizy doraźnych działań wynikających z bieżących potrzeb i reakcji na pojawiające się (niekiedy całkiem nowe) zagrożenia zdrowia publicznego. Dodatkowo można zauważyć, że zazwyczaj podręczniki dostosowane do aktualnie obowiązujących programów kształcenia studentów kierunków medycznych dość lakonicznie przedstawiają zadania i działania służby sanitarnej, często ograniczając się do przywołania zadań z regulacji ustawowej i niezbyt rozbudowanego, prostego ich opisu. Przykład stanowić może pozycja T.B. Kulik, A. Pacian (red. nauk.), Zdrowie publiczne, PZWL, Warszawa 2015.

${ }^{26}$ Ustawa (Obwieszczenie Marszałka Sejmu Rzeczypospolitej Polskiej z dnia 8 czerwca 2017 r. w sprawie ogłoszenia jednolitego tekstu ustawy o Państwowej Inspekcji Sanitarnej, Dz.U. 2017, poz. 1261 z dnia 28.06.2017) określa następujące zadania: Art. 1. Państwowa Inspekcja Sanitarna jest powołana do realizacji zadań z zakresu zdrowia publicznego, w szczególności poprzez sprawowanie nadzoru nad warunkami: 1) higieny środowiska, 2) higieny pracy w zakładach pracy, 3) higieny radiacyjnej, 4) higieny procesów nauczania i wychowania, 5) higieny wypoczynku i rekreacji, 6) zdrowotnymi żywności, żywienia i przedmiotów użytku, 7) higieniczno-sanitarnymi, jakie powinien spełniać personel medyczny, sprzęt oraz pomieszczenia, w których są udzielane świadczenia zdrowotne - w celu ochrony zdrowia ludzkiego przed niekorzystnym wpływem szkodliwości i uciążliwości środowiskowych, zapobiegania powstawaniu chorób, w tym chorób zakaźnych 
Schematyczna struktura organizacyjna inspekcji do 1 stycznia 2010 roku przedstawiona została na rysunku 3 .

\section{Państwowa Inspekcja Sanitarna \\ struktura organizacyjna}

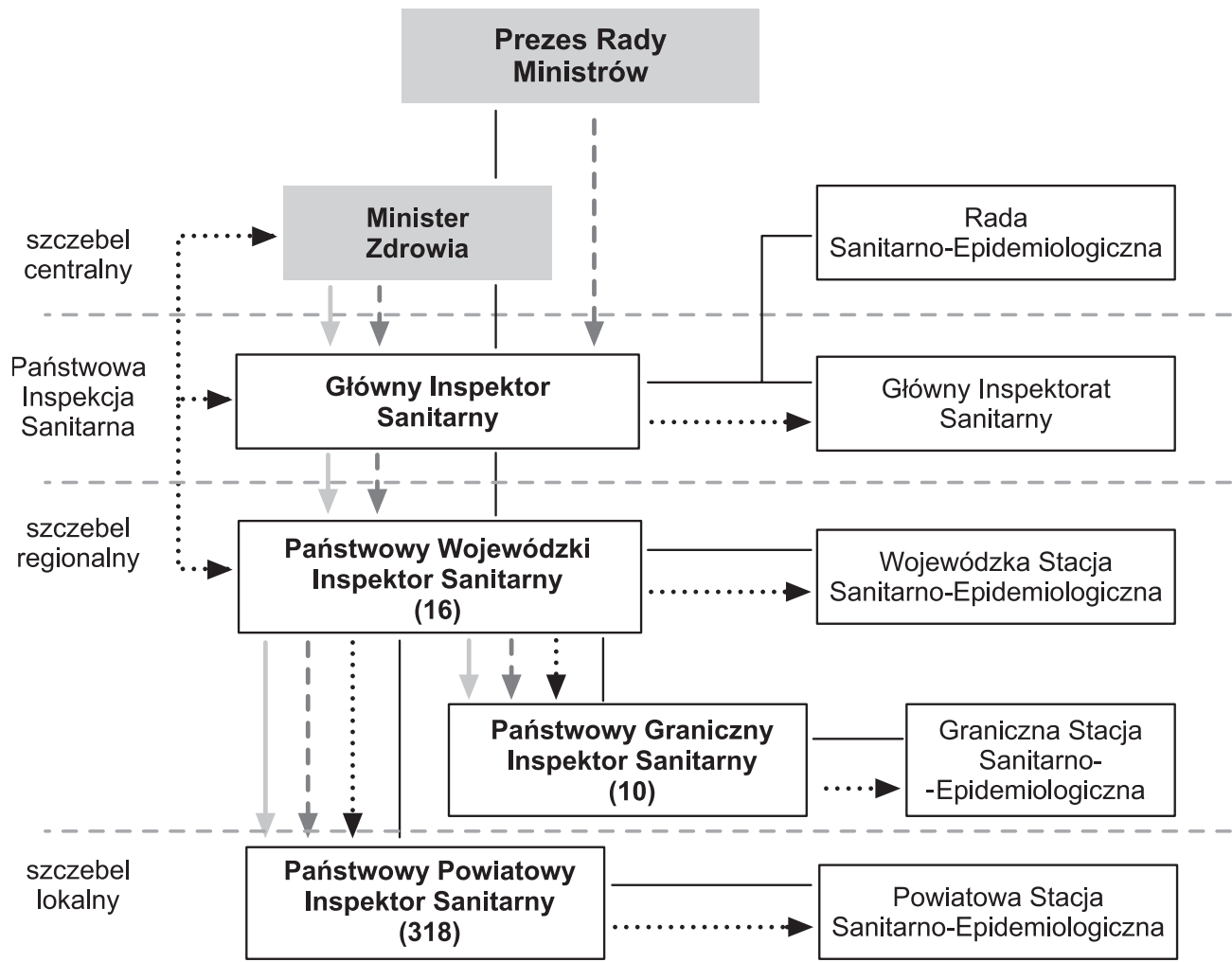

nadzór merytoryczny $\quad \rightarrow$ nadzór kadrowy $\quad \cdots \rightarrow$ finansowanie

Rysunek 3. Struktura organizacyjna PIS do 1 stycznia 2010 roku

Źródło: www.gis.gov.pl [dostęp 31.08.2009].

Państwową Inspekcję Sanitarną tworzyło łącznie ponad 340 jednostek zorganizowanych w strukturę o skodyfikowanych zadaniach, relacjach i zasadach finansowania działalności.

\footnotetext{
i zawodowych. Wykonawców zadań określa art. 10.1.: Zadania Państwowej Inspekcji Sanitarnej określone w rozdziale 1 wykonują następujące organy: 1) Główny Inspektor Sanitarny, 2) państwowy wojewódzki inspektor sanitarny, 3) państwowy powiatowy inspektor sanitarny, 4) państwowy graniczny inspektor sanitarny dla obszarów przejść granicznych drogowych, kolejowych, lotniczych, rzecznych i morskich, portów lotniczych i morskich oraz jednostek pływających na obszarze wód terytorialnych.
} 
Główny Inspektor Sanitarny był centralnym organem administracji rządowej podległym ministrowi właściwemu do spraw zdrowia. Aparatami pomocniczymi inspektorów były: głównego - główny inspektorat sanitarny, inspektorów niższych szczebli - stacje sanitarno-epidemiologiczne. Stacje te były (i są nadal) Zakładami Opieki Zdrowotnej. Wpisano je do rejestru ministra zdrowia na podstawie ustawy o zakładach opieki zdrowotnej ${ }^{27}$. Forma prawna jednostek inspekcji określała je jako jednostki budżetowe nieposiadające osobowości prawnej.

Struktura i organizacja Państwowej Inspekcji Sanitarnej na tym etapie spełniała fayolowską zasadę jedności rozkazodawstwa i jedności kierownictwa oraz zasadę Druckera o potrzebie prostych, jasnych wartości, celów i zadań jednoczących personel organiza$\mathrm{cji}^{28}$. Obecnie (od 2010 roku) została zastąpiona dość kuriozalnym rozwiązaniem, które faktycznie decyduje o równoczesnej podległości dwu podmiotom (rys. 4).

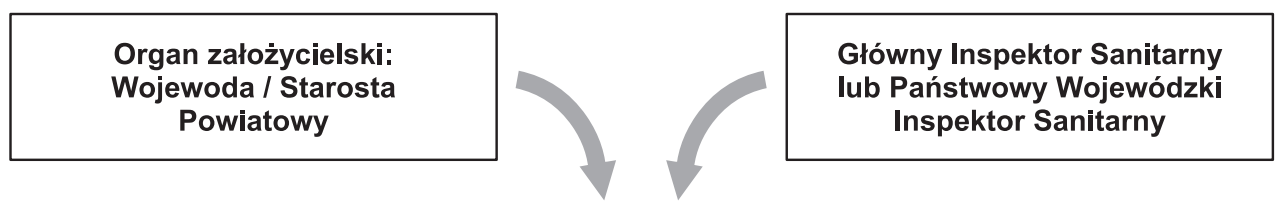

$$
\begin{gathered}
\text { Państwowi Inspektorzy Sanitarni } \\
\text { oraz Jednostki Państwowej } \\
\text { Inspekcji Sanitarnej (różne szczeble) }
\end{gathered}
$$

Rysunek 4. Schemat zarządzania Państwową Inspekcją Sanitarną od 2010 roku Źródło: opracowanie własne.

Rysuje się złamanie przywołanych jedności fayolowskich. Sytuacja taka wywołuje realne, niekiedy dość kłopotliwe trudności zarówno w zarządzaniu, jak i w wypełnianiu zadań (misji) wobec zdrowia publicznego. Widać to wyraźnie na przykład w obszarze finansowania, gdzie niejednoznaczność podległości bywa źródłem konfliktów i napięć.

Analiza zadań inspekcji (zarówno teoretycznych, jak i statutowych) pozwala na wyciągnięcie wniosku, że ich określenia są bardzo pojemne. W ramach tych samych sformułowań inspekcja może wykonywać różnorodne czynności. Faktycznie, w zależności od potrzeb czasów i polityki, treść i metody działań inspekcji ewoluowały. Lata powojenne to oczywiście przede wszystkim walka z epidemiami i nacisk na ogólną poprawę zdrowia populacji wyniszczonej wojną. W latach socjalizmu kładziono z kolei nacisk na działania kontrolne i karne - trzymanie ludności w ryzach, w ramach wszechogarniającego państwa. Od lat 90. XX wieku zmieniono kierunek. Nacisk położono na służbę społeczeństwu. Dostosowywano inspekcję do wymogów UE. Korzystając z programów i funduszy unijnych, forsownie modernizowano techniczne środki pracy i infrastrukturę. Inwestowano w personel - dokształcano (bądź korzystając z tzw. naturalnego ruchu zatrudnionych,

27 Obwieszczenie Marszałka Sejmu Rzeczypospolitej Polskiej z dnia 8 stycznia 2007 r. w sprawie ogłoszenia jednolitego tekstu ustawy o zakładach opieki zdrowotnej, Dz.U. 2007, nr 14, poz. 89.

${ }^{28} \mathrm{Na}$ ten temat: A.K. Koźmiński, Zarządzanie. Teoria i praktyka, PWN, Warszawa 2005. 
wymieniano) pracowników. Postawiono na wysokiej klasy fachowców, możliwie znających języki, gotowych do korzystania z najnowszej generacji aparatury laboratoryjnej i informatycznej. Obecnie punkt ciężkości przeniósł się z działań restrykcyjno-kontrolnych na profilaktykę (zgodnie z lansowanym hasłem „łatwiej zapobiegać niż leczyć”), oświatę zdrowotną i funkcjonujące w sposób ciągły zinformatyzowane systemy monitoringu, takie jak ogólnounijny system bezpieczeństwa żywności czy monitoring wody do spożycia.

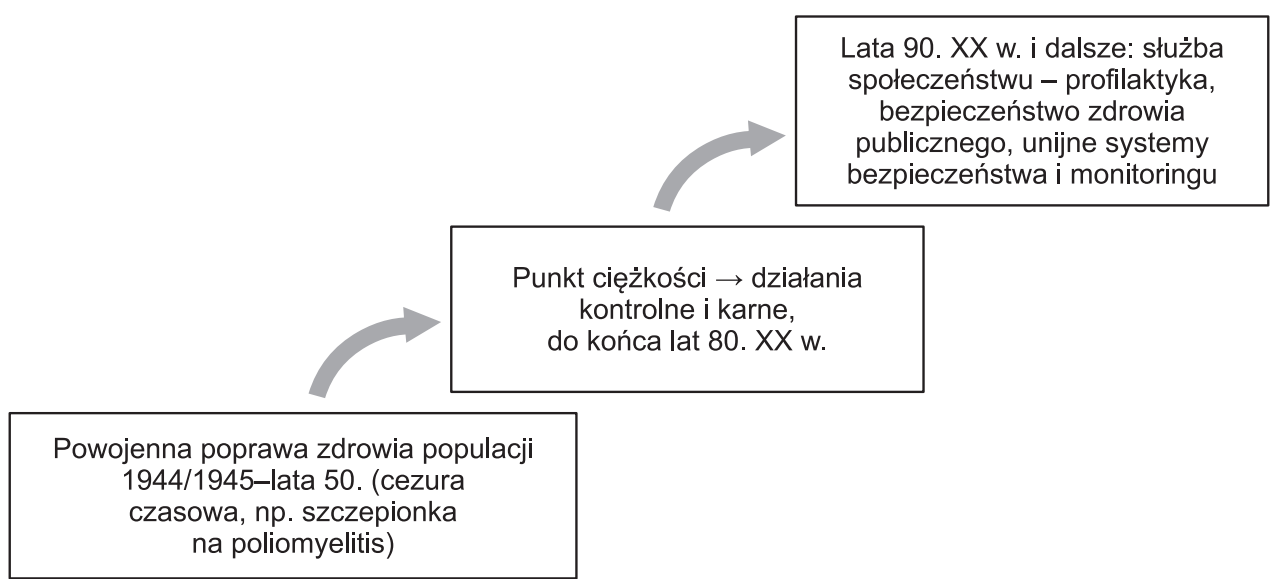

Rysunek 5. Schemat ewolucji zadań Państwowej Inspekcji Sanitarnej po II wojnie światowej

Źródło: opracowanie własne.

Stopniowo, do roku 2016, misja Inspekcji wyewoluowała w stronę uznania bezpieczeństwa żywności za najważniejsze zadanie ${ }^{29}$. Przyczyną była między innymi globalizacja, której konsekwencją stały się wydłużone łańcuchy żywnościowe (zwiększenie liczby ogniw na linii producent - końcowy odbiorca). Skutkiem jest między innymi coraz większa skłonność do wprowadzania do obrotu produktów żywnościowych niepełnowartościowych lub wręcz niebezpiecznych. Zagrożenia wynikają zarówno ze skażenia (chemicznego, mikrobiologicznego i fizycznego), jak i fałszowania żywności. Przy okazji, w warunkach globalizacji ${ }^{30}$, udowodnienie intencjonalności działań jest trudne lub wręcz niewykonalne ${ }^{31}$.

${ }^{29}$ W 1996 roku FAO (Foot and Agriculture Organization of the United Nations - Organizacja Narodów Zjednoczonych do spraw Wyżywienia i Rolnictwa) zdefiniowała bezpieczeństwo żywnościowe jako stan, w którym każdy człowiek będzie miał fizyczny i ekonomiczny dostęp do wystarczającej, bezpiecznej i właściwej pod względem odżywczym żywności - K. Marzęda-Młynarska, Globalne zarządzanie bezpieczeństwem żywnościowym na przełomie XX i XXI wieku, Wydawnictwo Uniwersytetu Marii Curie-Skłodowskiej, Lublin 2014, s. 17. Państwowa Inspekcja Sanitarna zajmuje się wyłącznie stroną jakościową, a więc zapewnieniem na rynku bezpiecznej zdrowotnie i właściwej odżywczo żywności. Należy też zwrócić uwagę, że działania w sferze bezpieczeństwa żywności to element inwestowania w odpowiednie odżywienie populacji. Badania wykazują, że inwestowanie w odpowiednie odżywienie przynosi największy zwrot spośród inwestycji prorozwojowych. Tamże, s. 296.

30 W tym przypadku przez globalizację należy rozumieć swobodny i błyskawiczny, transgraniczny, a nawet transkontynentalny przepływ towarów, kapitału i informacji.

31 S. Kowalczyk, Bezpieczeństwo żywności w epoce nierówności, „Kwartalnik Nauk o Przedsiębiorstwie” 2016 , nr 2 . 
Od roku 2015 pojawiła się dyskusja o ujednoliceniu zasad zarządzania bezpieczeństwem żywności ${ }^{32}$. Problem stanowi nakładanie się kompetencji organów państwa, ponieważ obecnie sprawami tymi zajmuje się dwóch ministrów (zdrowia - z jego ramienia Główny Inspektor Sanitarny i rolnictwa) oraz jeden kierownik urzędu centralnego (prezes Urzędu Ochrony Konkurencji i Konsumentów). Stan taki powoduje niejasność kompetencji, a skutkiem jest bałagan w zakresie rozkazodawstwa i odpowiedzialności ${ }^{33}$.

W ostatnich latach kolejnymi ważnymi zagadnieniami dla Inspekcji stały się działania epidemiologiczne - sprawy szczepień oraz sprawa środków zastępczych (tzw. dopalacze). Rozpętana przez ruchy antyszczepionkowe kampania prowadząca do unikania szczepień stanowi poważne zagrożenie dla biobezpieczeństwa populacji w skali globalnej. Społeczeństwa niektórych krajów zaczynają zbliżać się do progu odporności zbiorowiskowej34.

Sytuacja grozi wybuchem epidemii o ponadregionalnym zasięgu. Zagadnienie dopalaczy mieści się w szeroko rozumianym problemie psychoaktywnych używek (do których należą w szczególności narkotyki).

Analizowanie zachowań pracowników jednostek PIS w perspektywie organizacyjnej nasuwa wniosek, że traktują oni swoje miejsca pracy tak samo jak pracownicy sfery biznesowej. Wydaje się to upoważniać obserwatora do zastosowania obrazów metaforycznych, nawiązujących do opisów organizacji przez Morgana ${ }^{35}$.

Zaproponować można obraz Inspekcji jako:

- systemu politycznego i systemu dominacji,

- „czarnej dziury” ekonomicznej.

\section{System polityczny, dominacja i klientela}

Inspekcja jako „urządzenie społeczne” działające na obszarze całego kraju, którego szef podlega bezpośrednio ministrowi (dawniej sam był wiceministrem), nie jest wolna od polityki. Obserwuje się tu zjawisko określane pesymistycznie przez Webera jako kryptoplutokratyczny podział władzy (z tym, że odmienne są siły społeczne wykonujące zakulisowe posunięcia). Inspekcja jest zarówno wewnętrznie politycznym systemem rządzenia, jak i obiektem zewnętrznych działań politycznych. Już obsadzenie stanowiska

32 Jeszcze wcześniej reformę w tym zakresie proponował wicepremier Jerzy Hausner już w pierwszej dekadzie XXI wieku. Więcej na ten temat: J. Hausner, Pętle rozwoju. O polityce gospodarczej lat 2001-2005, Wydawnictwo Naukowe Scholar, Warszawa 2007, s. 62-75.

${ }_{33}$ Zjawisko takie znane jest w skali międzynarodowej, według WHO w wielu państwach odpowiedzialność za bezpieczeństwo żywności rozproszona jest pomiędzy różne instytucje, o dublujących się kompetencjach. Efektem jest brak spójnych strategii w zakresie ochrony przed chorobami powstającymi w wyniku skażenia żywności. K. Marzęda-Młynarskadz. cyt., s. 313.

34 Szczepienia. info, Narodowy Instytut Zdrowia Publicznego - Państwowy Zakład Higieny szczepienia. pzh.gov.pl/wszystko-o-szczepieniach/co-to-jest-odpornosc-zbiorowiskowa/ [dostęp: 5.05.2018]._Odporność zbiorowiskowa (inaczej odporność populacyjna, odporność stadna lub odporność grupowa) to ochrona osób nieuodpornionych w wyniku zaszczepienia wysokiego odsetka społeczeństwa. Próg odporności zbiorowiskowej jest definiowany jako odsetek osób uodpornionych w populacji, po osiągnięciu którego liczba nowych zakażonych zaczyna się zmniejszać, zwykle wymaga $90-95 \%$ populacji odpornej.

35 G. Morgan, Obrazy organizacji, PWN, Warszawa 2005. 
Głównego Inspektora Sanitarnego jest wynikiem przetargu w rządzącej partii lub koalicji. Z kolei on współdecyduje o obsadzie stanowisk 16 inspektorów wojewódzkich i ma wpływ na obsadę stanowisk kilkuset inspektorów niższych szczebli. Te dalsze decyzje są także wynikiem przetargów politycznych wyższego lub niższego rzędu. Ścierające się grupy interesów prowadzą ciche walki o obsadzenie „,należnych sobie” stanowisk. Inspekcja jest dla centrów władzy obiektem politycznie mało ważnym. Obsadzanie stanowisk jest typowe dla systemu klientalnego. Właściwa, jak się wydaje, jest definicja antropologiczna tego mechanizmu, która mówi, że „klientelizm oznacza podrzędność, podporządkowanie dla uzyskania albo utrzymania statusu”36. Umieszczenie przez polityków - patronów, „swoich ludzi" - klientów w tzw. terenie przynosi im wymierne korzyści w postaci wpływów w tymże terenie. Patron może, lecz nie musi, skorzystać z jakiejkolwiek usługi za ulokowanie na stanowisku swojego klienta. Już sama zdolność wykreowania klienta zwiększa prestiż patrona. Dodatkowo - niejako kredytując swojego partnera - ma u niego poczucie niespłaconego zobowiązania moralnego i na ogół bezwzględne (do pewnych granic oczywiście) posłuszeństwo. Taki stosunek w Inspekcji trwa zwykle przez okres całej kadencji i może być przedłużony na następną. Może też w wyniku zmian na centralnych szczeblach politycznych ulec odwróceniu. Zjawisko to w omawianej organizacji dotyczy z pewnością większości, jeśli nie wszystkich funkcjonariuszy wyższego i średniego szczebla.

Stosunki wewnątrz jednostek polegają na ścisłej dominacji wyższych szczebli nad niższymi. Istnieje jednak wyjątek. O ile szeregowy pracownik nie jest partnerem mogącym przeciwstawić się przełożonemu wysokiego szczebla, o tyle już nawet kilku takich pracowników - zorganizowanych w związek zawodowy - to partner wywołujący respekt kierownictw jednostek. Wynika to z faktu, że stanowiska są mocno upolitycznione. Konflikt z organizacjami związkowymi, mającymi w zależności od rządzącej opcji większą lub mniejszą siłę przetargową, stawia z kolei zarządzających w pozycji wasala. Efektem działań związkowców, którzy po powrocie na stanowiska pracy rozpływają się w szeregowej masie i nie ponoszą żadnej odpowiedzialności, jest wiele wymuszonych absurdalnych wręcz decyzji, szczególnie w sferze finansów (głównie wynagrodzeń).

\section{Ekonomiczna „czarna dziura”}

Odkładając na bok astrofizyczne niuanse, dla celów społecznej analizy można przywołać definicję filozoficzną. Czarna dziura to „obiekt astronomiczny będący źródłem tak silnego oddziaływania grawitacyjnego, że nie może się zeń wydostać żaden rodzaj energii czy materii. [...] Czarne dziury nie są bezpośrednio obserwowalne, ich istnienie stwierdza się na podstawie obserwacji wpływu silnego oddziaływania grawitacyjnego na obiekty w ich otoczeniu" 37 . Wymienione silne oddziaływanie grawitacyjne na inne obiekty to po prostu bezwzględne (jeśli można takiego określenia użyć wobec nieożywionego obiektu) wchłanianie wszelkich form materii i energii z otoczenia.

${ }^{36}$ A. Mączak, Klientela. Nieformalne systemy władzy w Polsce i Europie XVI-XVIII, Wydawnictwo Semper, Warszawa 2000, s. 17.

${ }^{37}$ M. Heller, Podglądanie Wszechświata, Znak, Kraków 2008, s. 201. 
Powołując się na opublikowane w 1892 roku prawo Wagnera, dotyczące stałego wzrostu wydatków publicznych, można stwierdzić, że również Państwowa Inspekcja Sanitarna wchłania wszystkie możliwe do uzyskania środki. Jest to wręcz niezbędne w warunkach stałego wzrostu liczby i jakości zadań, połączonego z permanentnym niedofinansowaniem. Współczesna empiryczna weryfikacja, która potwierdziła działanie prawa Wagnera, pozwoliła na określenie przyczyn takiego stanu rzeczy ${ }^{38}$. Spośród przyczyn (dotyczących skali makroekonomicznej) co najmniej dwie dotyczą gospodarki Inspekcji. Są to:

- przyczyny ekonomiczne i społeczne - stały wzrost zapotrzebowania na nowe rodzaje badań (co wynika z postępu nauk, w szczególności medycyny i biologii) oraz stały wzrost wydatków na nowe technologie badawcze (zapotrzebowanie na coraz nowszą i coraz kosztowniejszą aparaturę),

- przyczyny socjologiczne - „Każda istota żywa rozwija się, w przeciwnym razie zmierza ku śmierci" ${ }^{39}$. Dotyczy to również organizmów społecznych, w tym podmiotów publicznych oraz przyrody nieożywionej. Zasada jest tak wszechobejmująca, że sformułowano w astronomii koncepcję ekspandującego wszechświata. W tej sytuacji porównanie gospodarki finansowej Inspekcji z kosmiczną czarną dziurą wydaje się w pełni uzasadnione.

Powyższe teoretyczne rozważania należy skonfrontować z realiami gospodarki finansowej Państwowej Inspekcji Sanitarnej. Stacje sanitarno-epidemiologiczne są jednostkami budżetowymi. Zasady gospodarowania finansami jednostek podlegają rygorom określonym w Ustawie z dnia 27 sierpnia 2009 r. o finansach publicznych ${ }^{40}$. Podstawą gospodarki jest powiązanie z budżetem państwa metodą brutto (pełne powiązanie wydatków i dochodów z budżetem). Ponoszenie wydatków odbywa się zgodnie z zasadami określonymi w art. 44 ustawy narzucającym obowiązek celowości i oszczędności. Tak więc dysponowanie środkami publicznymi bezwzględnie winno być zgodne z celami statutowymi (cel wytyczony ustawowo przez państwo) oraz odbywać się w sposób optymalny i efektywny.

Fundamentalną sprawą jest wartość budżetu Inspekcji. Wartość ta corocznie podlega wahaniom w wymiarze nominalnym, jednak realnie ulega ciągłej deprecjacji ${ }^{41}$. Jest to szczególnie dotkliwe w działalności takiej instytucji, która musi posługiwać się najnowocześniejszymi technologiami medycznymi i biochemicznymi. Stały postęp naukowy w tych dziedzinach w połączeniu $\mathrm{z}$ koniecznością stosowania najnowszych metod badawczych wymaga poważnych nakładów inwestycyjnych oraz bieżącego zapewniania dostępu drogich materiałów medycznych i laboratoryjnych. Jednocześnie przy napiętym do granic możliwości budżecie postępuje dekapitalizacja majątku trwałego. Przyczyną są

38 P.M. Gaudemet, J. Molinier, Finanse publiczne, PWE, Warszawa 2000, s. 73-112.

39 Tamże, s. 78.

${ }^{40}$ Ustawa z dnia 27 sierpnia 2009 r. o finansach publicznych, Dz.U. 2009, nr 157, poz. 1240; Obwieszczenie Marszałka Sejmu Rzeczypospolitej Polskiej z dnia 14 października 2016 r. w sprawie ogłoszenia jednolitego tekstu ustawy o finansach publicznych, Dz.U. 2016, poz. 1870 z późn. zm.

${ }^{41}$ Można zaryzykować twierdzenie, że planowanie corocznych wydatków Inspekcji odbywa się w dość prymitywny sposób, przywodzący na myśl metody szkoły Ansoffa, z lat 60. XX wieku. Złośliwie określano, że polegają one na poszukiwaniu najlepszej metody osiągania przypadkowych rezultatów - K. Obłój, Strategia organizacji. W poszukiwaniu trwałej przewagi konkurencyjnej, PWE, Warszawa 2007, s. 60 i nast. 
tu zjawiska, takie jak wiek obiektów budowlanych stanowiących siedziby stacji sanitarno-epidemiologicznych (zdarzają się przypadki, że budynki liczą ponad 100 lat) oraz fakt, że infrastruktura laboratoryjna (aparatura) przygotowana została na moment wejścia Polski do Unii Europejskiej (czyli na 1 maja 2004 roku). W tym właśnie momencie sprzęt analityczny i badawczy, jakim dysponowały jednostki, był stosunkowo nowy i osiągał wysoki poziom techniczny. Stopniowo nastąpiło zestarzenie się wyposażenia, co przy permanentnym niedoborze środków z budżetu spowodowało niedostosowanie wyposażenia do wymaganych technik badawczych. Dodatkowo stworzyło to konieczność ponoszenia wydatków z budżetu na usuwanie licznych awarii i - w przypadkach gdy było to możliwe - na unowocześnianie aparatów pozostających w dyspozycji.

Kolejnym obciążeniem stało się dodawanie nowych zadań stacjom sanitarno-epidemiologicznym bądź to z tytułu zmian ustawowych, bądź na podstawie poleceń organów nadrzędnych. W wielu przypadkach w ślad za rozszerzaniem zakresu działania nie postępowało przydzielanie stosownych środków.

Problemem dla kierownictwa Inspekcji (zarówno na szczeblu centralnym, jak i regionalnym) jest również sytuacja w dziedzinie płac. Od lat utrzymuje się niedobór środków finansowych. Powoduje to istotne, ciągłe kłopoty - niezadowolenie personelu z poziomu wynagrodzeń (w wielu przypadkach kończy się odpływem wysoko wykwalifikowanych fachowców), jak również coraz poważniejsze trudności z naborem nowej, przygotowanej do skomplikowanych zadań kadry. Istotne też są zmiany systemowe następujące na poziomie ogólnokrajowym, które pochłaniają środki płacowe bez jednoczesnej rekompensaty w postaci zwiększenia budżetu Inspekcji. Można tu przywołać zmiany dotyczące obniżenia wieku emerytalnego (powstały wysokie koszty na odprawy emerytalne dla skokowo zwiększonej liczby odchodzących pracowników) oraz podwyżki dla personelu medycznego. Podwyżki te są konsekwencją ustawy z roku 2017, której inicjatorem był Minister Zdrowia. Spowodowały one konieczność dofinansowania wzrostu wynagrodzeń personelu pozamedycznego ze środków własnych Inspekcji, co powodowało kolejne zmniejszenie zasobu środków pozostających w dyspozycji Inspekcji.

Przedstawiona w zarysie sytuacja wskazuje na stan chronicznego niedofinansowania we wszystkich obszarach wydatków (bieżące płacowe i pozapłacowe, majątkowe). Wykonywanie zadań przy jednoczesnym długotrwałym niedoborze środków stwarza poważne problemy zarówno techniczne, jak i kadrowe.

\section{Wnioski}

Przeprowadzona analiza daje podstawę do sformułowania poniższych wniosków: Państwowa Inspekcja Sanitarna działa w warunkach organizacyjnych określonych na wstępie jako niespójne. Obowiązująca od 2010 roku szeroko rozumiana struktura organizacyjna łamie podstawowe zasady zarządzania, to jest zasadę jedności rozkazodawstwa i jedności kierownictwa oraz zasadę potrzeby prostych, jasnych wartości, celów i zadań. Struktura taka implikuje szereg problemów, w tym w szczególności prawnych oraz ekonomicznych (brak podmiotu pełniącego jednoznaczną rolę „,gospodarza”). Jednocześnie utrzymujący 
się od wielu lat niedobór (w stosunku do zadań) środków finansowych zarówno stwarza poważne problemy w zakresie bieżącego działania, jak i stanowi barierę rozwojową. W zestawieniu z wagą działań inspekcji w obszarze biobezpieczeństwa populacji wskazuje to na potrzebę zmian.

\section{Bibliografia}

Adamik A., Nauka o organizacji, Wolters Kluwer business, Warszawa 2013.

Behringer W., Kulturgeschichte des Klimas, na podstawie wydania czeskiego: Kulturni dějiny klimatu, Nakladatelství Paseka, Praha-Litomyšl 2010.

Biblia to jest pismo święte starego i nowego testamentu, Brytyjskie i Zagraniczne Towarzystwo Biblijne, Warszawa 1975.

Brydak L.B., Grypa: pandemia grypy - mit czy realne zagrożenie, Oficyna Wydawnicza Rytm, Warszawa 2008.

Domaradzki J., O definicjach ochrony zdrowia i choroby, „Folia Medica Lodziensa” 2013, $\mathrm{nr}$ 40/1, http://yadda.icm.edu.pl/yadda/element/bwmeta1.element.psjd-277d7478-0030-47a4b518-3ecc6fa630b9 [dostęp: 31.08.2018].

Esposito R., Pojęcia polityczne. Wspólnota, immunizacja, biopolityka, Towarzystwo Autorów i Wydawców Prac Naukowych Universitas, Kraków 2015.

Foucault M., Bezpieczeństwo, terytorium, populacja, PWN, Warszawa 2010.

Gaudemet P.M., Molinier J., Finanse publiczne, PWE, Warszawa 2000.

Główny Inspektorat Sanitarny, https://gis.gov.pl [dostęp: 31.08.2009].

Habermas J., Strukturalne przeobrażenia sfery publicznej, PWN, Warszawa 2007.

Harari Y.N., Homo deus. Krótka historia jutra, Wydawnictwo Literackie, Kraków 2018.

Hausner J., Pętle rozwoju. O polityce gospodarczej lat 2001-2005, Wydawnictwo Naukowe Scholar, Warszawa 2007.

Heller M., Podglądanie Wszechświata, Znak, Kraków 2008.

Huizinga J., Jesień średniowiecza, PIW, Warszawa 1967.

Kowalczyk S., Bezpieczeństwo żywności w epoce nierówności, „Kwartalnik Nauk o Przedsiębiorstwie" 2016, nr 2.

Kowalska M., Cele i zadania zdrowia publicznego, Katedra i Zakład Epidemiologii, Śląski Uniwersytet Medyczny w Katowicach, http://epidemiologia.sum.edu.pl/wp-content/uploads/2012/10/Seminarium-1.pdf [dostęp: 10.05.2018].

Koźmiński A.K., Zarządzanie. Teoria i praktyka, PWN, Warszawa 2005.

Lalonde M., A New Perspective On The Health Of Canadians, a working document, http:// www.phac-aspc.gc.ca/ph-sp/pdf/perspect-eng.pdf [dostęp: 5.05.2018].

Magdzik W., Naruszewicz-Lesiuk D., Zieliński A., Wakcynologia, Wydawnictwo $\alpha$-medica press, Bielsko-Biała 2007.

Malthus T., Prawo ludności, Wydawnictwo De Agostini, Ediciones Altaya Polska, Warszawa 2003. 
Marzęda-Młynarska K., Globalne zarządzanie bezpieczeństwem żywnościowym na przełomie XX i XXI wieku, Wydawnictwo Uniwersytetu Marii Curie-Skłodowskiej, Lublin 2014.

Mączak A., Klientela. Nieformalne systemy władzy w Polsce i Europie XVI-XVIII, Wydawnictwo Semper, Warszawa 2000.

Michalak J., Zakażenia szpitalne jako problem zarzadczy i miernikjakości opieki w szpitalu, [w:] A. Denys, Zakażenia szpitalne - wybrane zagadnienia, Wolters Kluwer Polska, Warszawa 2012.

Morgan G., Obrazy organizacji, PWN, Warszawa 2005.

Obłój K., Strategia organizacji. W poszukiwaniu trwałej przewagi konkurencyjnej, PWE, Warszawa 2007.

Obwieszczenie Marszałka Sejmu Rzeczypospolitej Polskiej z dnia 8 stycznia 2007 r. w sprawie ogłoszenia jednolitego tekstu ustawy o zakładach opieki zdrowotnej, Dz.U. 2007, nr 14, poz. 89.

Obwieszczenie Marszałka Sejmu Rzeczypospolitej Polskiej z dnia 14 października 2016 r. w sprawie ogłoszenia jednolitego tekstu ustawy o finansach publicznych, Dz.U. 2016, poz. 1870 z późn. zm.

Obwieszczenie Marszałka Sejmu Rzeczypospolitej Polskiej z dnia 8 czerwca 2017 r. w sprawie ogłoszenia jednolitego tekstu ustawy o Państwowej Inspekcji Sanitarnej, Dz.U. 2017, poz. 1261.

Szczepienia. info, Narodowy Instytut Zdrowia Publicznego - Państwowy Zakład Higieny szczepienia.pzh.gov.pl/wszystko-o-szczepieniach/co-to-jest-odpornosc-zbiorowiskowa/ [dostęp: 5.05.2018].

Ustawa z dnia 14 marca 1985 r. o Państwowej Inspekcji Sanitarnej, Dz.U. 1985, nr 12, poz. 49.

Ustawa z dnia 27 sierpnia 2009 r. o finansach publicznych, Dz.U. 2009, nr 157, poz. 1240.

Włodarczyk W.C., Uwagi o modelach warunkowań i zróżnicowań stanu zdrowia, [w:] Model oceny wpływu regulacji prawnych i instytucjonalnych na zdrowie, Narodowy Instytut Zdrowia Publicznego - Państwowy Zakład Higieny, Kraków-Warszawa 2017.

\section{Streszczenie \\ Bezpieczeństwo biologiczne populacji. Zdrowie publiczne a Państwowa Inspekcja Sanitarna jako najważniejsza instytucja sfery zdrowia publicznego}

Celem artykułu jest analiza działań Państwowej Inspekcji Sanitarnej. Część wstępna przedstawia pokrótce historię działań w dziedzinie bezpieczeństwa biologicznego gatunku ludzkiego, a także ewolucję koncepcji zdrowia publicznego. Część główna opracowania opisuje działania w szeroko pojętej dziedzinie bezpieczeństwa biologicznego, zdrowia publicznego ludności, jak również prezentuje badaną instytucję. Analiza pozwala stwierdzić, że omawiana instytucja wymaga zmian organizacyjnych.

Słowa kluczowe: bezpieczeństwo biologiczne, zdrowie publiczne, Państwowa Inspekcja Sanitarna 


\section{Summary}

Biological security of the population. Public health and the State Sanitary Inspectorate as the most important institution of the public health sphere

The purpose of this article is to analyse the actions of the State Sanitary Inspectorate. The first part of the article presents a brief history of biological security relating to human beings and an outline of the evolution of the concept of public health. The main section of the article outlines activities within the broadly defined field of biosecurity/public health and presents the institution being analysed. The analysis concludes that the State Sanitary Inspectorate requires organisational changes.

Keywords: biological security, public health, State Sanitary Inspectorate 


\section{Piotr Ogrodowczyk (D) https://orcid.org/0000-0001-9309-0305}

Badacz niezależny

\section{„Środki aktywne" - skuteczne działania rosyjskich służb specjalnych ${ }^{1}$}

Początek nowego tysiąclecia to szybki rozwój technologiczny, przynoszący wiele zmian w dostępie do informacji. Szybkość, z jaką jest ona przekazywana, powoduje, że w coraz liczniejszych przypadkach nie ma możliwości sprawdzenia jej wiarygodności, zanim zostanie ona przyswojona i uznana za prawdziwą. Informacja odpowiednio przygotowana i podana w sposób łatwy i przystępny może być bardzo groźną bronią w szerszym ujęciu. Celem artykułu jest pokazanie, że docierając z odpowiednim przekazem do dużej grupy osób, można wpłynąć na ich wybory, a w konsekwencji na politykę realizowaną w konkretnym państwie, a nawet regionie. Można sformułować hipotezę, że na współczesnej scenie politycznej rosyjskie służby specjalne, posiadające odpowiednie finansowanie i doświadczenie w tego typu działaniach, są w stanie znacząco naruszyć kruchą równowagę w zakresie bezpieczeństwa międzynarodowego. Do jej udowodnienia została zastosowana metoda historyczna polegająca na analizie dostępnych dokumentów oraz źródeł².

\section{Bezpieczeństwo polityczne}

Termin bezpieczeństwo jest wyrazem pochodzącym od łacińskiego rzeczownika securitas, będącego połączeniem dwóch wyrazów łacińskich - sine oraz cura, sine można przetłumaczyć na język polski jako bez, natomiast cura jako zmartwienie, strach lub obawę. Można więc przyjąć, że w połączeniu jest to brak zmartwień, poczucia strachu, jak i obaw. Słowo przetrwało w podobnej wersji w językach europejskich, w języku angielskim jest

\footnotetext{
${ }^{1}$ Fragmenty artykułu pochodzą z przygotowywanej przez autora rozprawy doktorskiej pod opieką naukową prof. zw. dr. hab. Marka J. Malinowskiego.

${ }^{2}$ Należy pamiętać, że ze względu na utajnienie działań podejmowanych przez służby specjalne dostępność dokumentów i wiarygodnych źródeł jest w dużym stopniu ograniczona.
} 
to security, natomiast w języku francuskim sécurité. Ujmując krótko, bezpieczeństwo należy rozumieć jako proces, w którym stan bezpieczeństwa i jego organizacja podlegają permanentnym, dynamicznym zmianom wynikającym z naturalnych oddziaływań i uwarunkowań. Dlatego też można przyjąć, że konieczna jest ciągła działalność jednostek, społeczności lokalnych, organizacji lokalnych i międzynarodowych oraz państw w tworzeniu odpowiedniego, przyjętego stanu bezpieczeństwa ${ }^{3}$. Tak naprawdę istnieje bardzo wiele definicji bezpieczeństwa i jego rodzajów, jednak na potrzeby tego artykułu skupię się wyłącznie na bezpieczeństwie politycznym.

Pojęcie bezpieczeństwa politycznego można określić ogólnie jako możliwość dość swobodnego kształtowania przez państwo swojej polityki wewnętrznej i zewnętrznej w zakresie systemu zarówno politycznego, jak i społecznego, gospodarczego czy też kulturalnego, z jednoczesnym zachowaniem odrębności narodowej. Można więc przyjąć, że bezpieczeństwo polityczne jest związane z niezależnymi decyzjami podejmowanymi przez władze odnośnie do najważniejszych obszarów życia społecznego w danym państwie.

Wydaje się, że bardzo trafną definicję bezpieczeństwa politycznego podaje Sławomir Zalewski, który uważa, że oznacza ona „stabilność systemu politycznego, wyrażającą interesy podstawowych grup społecznych i zapewniającej społeczno-polityczną stabilność społeczeństwa, przy nieobecności społecznych i politycznych konfliktów. Z punktu widzenia zewnętrznych warunków istnienia społeczeństwa polityczne bezpieczeństwo oznacza zdolność organów władzy państwowej do dbania o podstawowe interesy kraju na arenie międzynarodowej, zapewniania ich całościowego ujęcia i suwerenności, aktywny udział w stosunkach międzynarodowych. Bezpieczeństwo polityczne powinno być rozpatrywane łącznie $\mathrm{w}$ aspekcie wewnętrznym i zewnętrznym, $\mathrm{z}$ uwzględnieniem wzajemnych powiązań"4.

\section{Działania słuzb specjalnych w zakresie zapewnienia bezpieczeństwa państwa}

Analizując sposoby zapewnienia odpowiedniego bezpieczeństwa, należy wziąć pod uwagę kilka instytucji działających w ramach struktur danego państwa. We współczesnej Europie zapewnienie bezpieczeństwa poszczególnych krajów staje się przede wszystkim domeną odpowiednio przygotowanych do działania służb specjalnych, w szczególności odpowiedzialnych za działalność wywiadowczą i kontrwywiadowczą. Ważnym elementem jest utrzymanie cywilnej kontroli nad działaniami tajnych służb, które z natury są przecież niejawne lub wręcz utajnione, co zwiększa ich skuteczność w obliczu aktualnych zagrożeń, ponieważ brak tego typu kontroli może prowadzić, co miało miejsce wielokrotnie

\footnotetext{
3 W. Pokruszyński, Teoretyczne aspekty bezpieczeństwa, Wyższa Szkoła Gospodarki Euroregionalnej im. Alcide De Gasperi, Józefów 2010, s. 9.

${ }^{4}$ S. Zalewski, Strategia jako instrument bezpieczeństwa politycznego państwa, „Doctrina. Studia społeczno-polityczne" 2006, nr 6, s. 31-32. 
w przeszłości, do wyizolowania tej sfery z obszaru działań państwa na polu zapewnienia bezpieczeństwa ${ }^{5}$.

Skuteczne działanie służb specjalnych wiąże się z odpowiednią koordynacją ich działania. Jest to aktualnie jeden $z$ najważniejszych elementów funkcjonowania służb specjalnych. Jak słusznie zauważa Sławomir Zalewski: „W sytuacji zróżnicowania form instytucjonalnych i organizacyjnych w sferze bezpieczeństwa, w warunkach zwiększenia liczby i uprawnień państwowych podmiotów działających w tym obszarze, w dobie ich koniecznej specjalizacji, na znaczeniu zyskują problemy koordynacji działań”.

Służby specjalne należy usytuować w strukturze państwa jako organy pełniące przede wszystkim funkcję bezpieczeństwa wewnętrznego. W każdym państwie na system instytucjonalny bezpieczeństwa wewnętrznego składają się organy i urzędy o właściwości ogólnej, dla których zadania dotyczące tego rodzaju bezpieczeństwa stanowią jedną z wielu ról pełnionych w państwie, a także instytucje i organy wyspecjalizowane, dla których bezpieczeństwo wewnętrzne oznacza główny zakres zadań7.

Zarządzanie państwem w wielu aspektach przypomina zarządzanie przedsiębiorstwem, różnica jednak pojawia się w przypadku ewentualnych konsekwencji podjęcia błędnej decyzji. W przypadku przedsiębiorstwa będzie to bankructwo, w przypadku sceny politycznej konsekwencje mogą być katastrofalne zarówno dla społeczeństwa, jak i samego kraju. Dlatego też tak ważna jest „,informacja”, a raczej „informacje” pozyskiwane przez służby wywiadowcze. Jak ważny jest wywiad w procesie zarządzania państwem, idealnie podsumowuje Alexandre de Marenches, który przez jedenaście lat kierował francuskimi tajnymi służbami, między innymi za kadencji prezydentów Georgesa Pompidou i Giscarda d'Estainga: „Wiele tarcz wywiadu przypomina samolot. W kokpicie ten, do którego należą decyzje - pilot, szef państwa. Nie może się on obyć bez dokładnych wskazówek. Jeśli ma złe służby, kierowane przez amatorów, głupców lub ludzi niekompetentnych, odpowiedzialność spadnie na niego. Jego pozycja międzynarodowa osłabnie, to oczywiste. Zabraknie mu elementów warunkujących decyzję. Świat jest tak ukształtowany, że prezydent, na ogół, odbywa lot w trudnych warunkach. Często pilotuje przy widoczności zerowej. Jeśli nie ma narzędzi w rodzaju wysokościomierza czy radaru i nie wie, czego może oczekiwać, zmierza do katastrofy. W żadnym momencie dziejów żaden kraj godny tego miana nie był pozbawiony służb wywiadowczych. Jak mówił Sun Tzu: Wywiad to preludium zwycięstwa"8.

5 A. Harasimowicz, Polska polityka bezpieczeństwa w XX i XXI wieku-niektóre dylematy (głos w dyskusji), [w:] R. Czulda, R. Łoś, J. Reginia-Zachorski (red. nauk.), NATO wobec wyzwań wspótczesnego świata, Instytut Badań nad Stosunkami Międzynarodowymi w Warszawie, Katedra Teorii Polityki Zagranicznej i Bezpieczeństwa - Wydział Studiów Międzynarodowych i Politologicznych Uniwersytetu Łódzkiego, Warszawa-Lódź 2013, s. 137.

${ }^{6}$ S. Zalewski, Stużby specjalne-programowanie, nadzór, koordynacja, Kancelaria Prezesa Rady Ministrów, Warszawa 2003, s. 36.

${ }^{7}$ G. Rydlewski, Ksztalt systemu instytucjonalnego bezpieczeństwa wewnętrznego w Polsce, [w:] S. Sulowski, M. Brzeziński (red.), Bezpieczeństwo wewnętrzne państwa. Wybrane zagadnienia, Dom Wydawniczy Elipsa, Warszawa 2009, s. 134.

${ }^{8}$ O. Christine, A. Marenches de, Sekrety szpiegów i książąt. Relacje szefa francuskich stużb specjalnych, Wydawnictwo Editions Spotkania, Warszawa 1992, s. 117. 
W dziedzinie pozyskiwania informacji wywiadowczych, czyli mówiąc krótko szpiegostwa, olbrzymi wkład mają starożytne Chiny ze względu na dzieła generała i filozofa Sun Tzu, który XIII rozdział swojej książki pod tytułem Sztuka wojny poświęcił temu tematowi. Jego argumenty za wykorzystywaniem szpiegów opierały się w dużej mierze na ekonomii. Prowadzenie wojny oznaczało ogromny wydatek związany z utrzymaniem i wyposażeniem wojska, ale również stanowiło o mniejszych wpływach z podatków i braku rąk do pracy. Jedynie wydatki na działalność szpiegowską były uzasadnione w tej sytuacji, ponieważ informacje pozyskane tą metodą wpływały na szybsze działania wojenne i sprawiały według Sun Tzu, że wojna stawała się bardziej humanitarna ${ }^{9}$. Pozostając na terenie Azji, wspomnieć należy o podręczniku dla władców pod tytułem Arthaśāstra zredagowanym przez Kautilyę ${ }^{10}$. W rozdziałach XI i XII opisana została cała koncepcja wykorzystania szpiegów do pozyskiwania informacji. Agenci zostali podzieleni na dwie grupy, z jednej były to „organizacje szpiegowskie” (samsthah), których członkowie byli finansowani ze skarbu państwa i dbali o dwór królewski, a z drugiej wędrowni szpiedzy nazywani sancaras, którzy przemieszczali się po całym kraju. Co ciekawe, obie te struktury nie miały prawa nic o sobie wiedzieć ${ }^{11}$.

W czasach oświecenia myśliciele wywodzący się z kręgów wojskowych zdefiniowali działalność wywiadowczą na rzecz operacji militarnych. Ważnym dziełem z tamtego okresu jest książka Mes Rêveries napisana przez marszałka Francji Maurycego Saskiego na podstawie wieloletnich doświadczeń. W jednym z fragmentów stwierdził, iż: „Nie da się przecenić znaczenia, jakie w działaniach wojennych przypisuje się szpiegom i przewodnikom [...] na dobrych szpiegów warto wydać każde pieniądze. Należy ich wybierać spośród mieszkańców kraju, w którym jest prowadzona wojna. Trzeba zatrudniać inteligentnych, bystrych i mądrych ludzi. Muszą być rozproszeni wszędzie, wśród oficerów, generałów, markietanek"12. Jednak najbardziej znanym traktatem wojskowym z tego okresu jest dzieło króla Prus, Fryderyka Wielkiego, Instrukcja dla generałów. Po klęsce, jaką zadał Francuzom 5 listopada 1757 roku pod Rossbachem, napisał o dowódcy wojsk nieprzyjacielskich: „Przed marszałkiem Soubise kroczy zawsze setka kucharzy; mnie poprzedza setka szpiegów"13.

Budowa odpowiednich struktur wywiadowczych jest bardzo trudnym i czasochłonnym zadaniem, ponieważ liczne elementy są ze sobą wzajemnie połączone zarówno funkcjonalnie, jak i informacyjnie. Budowa sprawnie działającego aparatu wywiadowczego, czyli tzw. centrali, oraz placówek działających w terenie, oczywiście za granicą, wymaga wieloletniej, systematycznej i konsekwentnej pracy. Dodatkowym utrudnieniem jest fakt, że poszczególne elementy struktury tej służby wymagają ciągłej rozbudowy oraz dostosowania się do coraz to nowych potrzeb wynikających z przydzielanych nowych zadań. Oznacza to w praktyce duże nakłady pracy i środków finansowych. Dlatego też

9 T. Crowdy, Historia szpiegostwa i agentury, Wydawnictwo Bellona, Warszawa 2010, s. 25-26.

${ }^{10}$ Podawane są również nazwy: Vishnugupta i Chanakya.

${ }^{11}$ N.K. Singh, Encyclopaedia of Hinduism, vol. 49, Centre for International Religious Studies, 1997, s. 1150; Kautilya, Arthaśástra, Government Press, Bangalore 1915.

${ }_{12}$ Zob. M. Saxe comte de, Mes Rêveries, Pérau, Amsterdam-Lipsk 1696-1750, s. 1700-1767.

${ }^{13}$ T. Crowdy, s. 94-95 
coraz częściej wykorzystuje się nowe rozwiązania związane ze zmianami zachodzącymi zarówno w sferze technologicznej, jak i społecznej.

\section{„Środki aktywne” - współczesne działania służb wywiadowczych}

Rozwój Internetu, który jako sieć błyskawicznie obejmuje praktycznie wszystkie obszary naszego życia, powstanie portali społecznościowych, ale również wykorzystywanie globalnej sieci do przesyłania informacji prywatnych, przemysłowych czy militarnych powoduje, że skutecznym sposobem wpływania na system bezpieczeństwa międzynarodowego stają się ,środki aktywne”. Można śmiało zaryzykować stwierdzenie, że od wielu lat mamy do czynienia z olbrzymim wpływem środków masowego przekazu na scenę polityczną zarówno w ujęciu regionalnym, jak i lokalnym, ale również na społeczeństwa. Możliwości techniczne naszych czasów pozwalają na bezproblemowe przekraczanie granic, przez co zwykłe fizyczne oddziaływanie coraz częściej zastępowane jest podawaniem zafałszowanych informacji oraz podświadomej manipulacji. Prezydent Michaił Gorbaczow już w 1987 roku zauważył, że konfrontacja nuklearna nie jest dobrym środkiem do osiągnięcia zamierzonych celów, ponieważ zniszczenia będą poważne, a korzyść, jaka wyniknie ze zdobycia radioaktywnych ruin, będzie niewielka.

Określenie środki aktywne lub używane zamiennie przedsięwzięcia aktywne oznacza specyficzne ofensywne działania służb wywiadowczych, czyli służb specjalnych danego państwa, skorelowanych z jego polityką zagraniczną, które mają na celu uzyskanie skutecznego wpływu na żywotne sfery życia politycznego innych państw (ich politykę zagraniczną, rozwiązywanie problemów międzynarodowych), wprowadzenie władz tych państw w błąd, poderwanie i osłabienie ich pozycji na arenie międzynarodowej, uniemożliwienie realizacji ich planów i zamiarów lub osiągnięcie innych celów ${ }^{14}$.

Pojęcie środków aktywnych szerzej zdefiniowano w Słowniku kontrwywiadowczym, wydanym przez Wyższą Szkołę KGB im. Feliksa Dzierżyńskiego w 1972 roku. Środki aktywne określono w słowniku jako „działania kontrwywiadu umożliwiające przejrzenie zamiarów przeciwnika, pozwalające uprzedzić jego niepożądane kroki, wprowadzić przeciwnika w błąd, przechwycić jego inicjatywę, udaremnić jego akcje dywersyjne. Środki aktywne w odróżnieniu od środków ochronnych, na przykład dotyczących zabezpieczenia reżimu tajności oraz ochrony tajemnicy państwowej i wojskowej, mają charakter ofensywny, umożliwiają wykrycie i przerwanie wrogiej działalności we wczesnym jej stadium, zmuszają przeciwnika do zdemaskowania się, pozwalają narzucić mu swoją wolę, zmuszają do działań w niesprzyjających warunkach oraz kierunkach pożądanych dla organów kontrwywiadu ${ }^{15}$.

Współcześnie do środków aktywnych zalicza się ogólnie działania w postaci wykorzystania ,agentury wpływu”, posługiwanie się „organizacjami fasadowymi” oraz akty

14 J. Larecki, Wielki leksykon stużb specjalnych świata, „Książka i Wiedza”, Warszawa 2007, s. 527.

15 J. Darczewska, P. Żochowski, Środki aktywne. Rosyjski towar eksportowy, „Punkt Widzenia” 2007, nr 64, s. 13. 
przemocy. Celem działania służb specjalnych w tym obszarze jest swego rodzaju wykorzystanie organizacji i grup, których działalność sprzyja polityce państwa, w ramach którego działają. Funkcjonowanie pewnych grup społecznych czy politycznych w wielu przypadkach jest zgodne z interesem jakiegoś kraju i ma, lub może mieć w przyszłości, wpływ na jego życie polityczne i społeczne. Jest to podstawą do podjęcia działań w celu ich penetracji i manipulowania członkami, a w konsekwencji częścią opinii publicznej. W wielu przypadkach tego typu podmiot jest tworzony od podstaw, by służby specjalne miały gwarancję sprawowania nad nim pełnej kontroli (mogą to być zarówno partie polityczne, jak i organizacje społeczne, społeczno-polityczne, a nawet grupy subkulturowe) ${ }^{16}$.

Środki tego typu są stosowane na przykład do oddziaływania na konkretne osoby z kręgu władzy, ale również na te mające wpływ na politykę na danym obszarze. Plan Pracy I Zarządu Głównego KGB na 1984 rok podkreślał, że głównym celem działań aktywnych będzie Watykan oraz osoba papieża Jana Pawła II. W ocenie KGB Watykan uważał, że „polski Kościół umacnia swą pozycję w państwie i starania te mogą być rozszerzone na inne kraje socjalistyczne", przede wszystkim na Węgry i Jugosławię. Dla przeciwdziałania tej polityce w KGB zaplanowano „szeroko zakrojone środki aktywne”, których celem miało być zdyskredytowanie Jana Pawła II, rozbudzenie niesnasek w Kościele oraz osłabienie autorytetu papieża ${ }^{17}$.

Posiadająca sygnaturę,,ściśle tajne” instrukcja nr 733 z 19 grudnia 1984 roku „Praca nad Watykanem" zobowiązywała rezydentów do podjęcia działań aktywnych zmierzających do stworzenia wewnątrz Kościoła opozycji wobec Ojca Świętego. Działania aktywne miały obejmować wykorzystanie wszelkich istniejących niesnasek wewnętrznych w Watykanie, w tym przejawów niezadowolenia wpływowych kardynałów, przeciwdziałanie rozszerzaniu kontaktów między Watykanem a Cerkwią Prawosławną oraz innymi kościołami chrześcijańskimi działającymi w krajach socjalistycznych, wzmacnianie negatywnych opinii wysokich osobistości katolickich wobec niektórych aspektów polityki zagranicznej Jana Pawła II. Przede wszystkim należało wykorzystywać niezadowolenie wśród włoskich członków Kurii Rzymskiej z planowanego przez papieża wzmocnienia swojej pozycji drogą awansowania między innymi Polaków oraz demaskowanie współpracy między przedstawicielami Watykanu i Kościoła katolickiego a CIA i służbami specjalnymi państw NATO"18.

Służby specjalne współczesnej Rosji tworzą nowe rozwiązania w zakresie stosowania środków aktywnych i dopasowują je do zmieniających się warunków geopolitycznych, dlatego też współcześnie stosowanie środków aktywnych cechuje ich regionalizacja. Tego typu podejście uwzględnia specyfikę regionalną i kulturową obszaru oddziaływania, dzięki czemu dystans mentalny i kulturowy między agresorem a adresatem podejmowanych działań ulega skróceniu. Skuteczność operacji związanych ze środkami wpływu w dużym

${ }^{16}$ K. Baraniuk, ,Środki aktywne” w wykorzystaniu radzieckich stużb wywiadowczych. Refleksje w kontekście kryzysu na Ukrainie, [w:] M. Górka (red.), Wywiad i kontrwywiad w polityce międzynarodowej na przetomie XX i XXI wieku, Wydawnictwo Difin, Warszawa 2016, s. 118.

17 C. Andrew, O. Gordijewski (red.), More Instructions from the Centre: Top Secret Files on KGB Global Operations, 1975-1985, Frank Cass, Londyn 1992, s. 47.

18 Tamże, s. 47-52. 
stopniu zależy nie tylko od diagnozy panującego układu sił i koniunktury politycznej, ale również od politycznej kultury i istniejących potrzeb społecznych. Taka wszechstronna, ale jednocześnie regionalna diagnoza umożliwia bardzo skuteczne działania przeciwstawiania sobie elit i społeczeństwa atakowanego kraju. Jako przykład można podać badania wspierane przez władze na Kremlu, w 2011 roku Kaliningradzki Ośrodek Badań Polskich otrzymał prezydencki grant na badania polskich elit ${ }^{19}$.

Ciągle udoskonalane metody stosowania środków aktywnych i dostosowywanie ich do zmieniających się warunków geopolitycznych i społecznych powodują, że służby specjalne posługujące się przede wszystkim „białym wywiadem”20 stają przed poważnymi problemami. Analiza pozyskanych informacji wymaga bardzo złożonego podejścia:

- obserwowane wydarzenia muszą zostać umiejscowione w kontekście znanych celów strategicznych i taktycznych polityki zagranicznej Rosji, czyli wytypowania obszarów szczególnego zainteresowania operacyjnego służb rosyjskich, ale również potencjalnych instytucji i środowisk społecznych podatnych na oddziaływanie ze strony Rosji,

- stałego monitoringu i analizy wydarzeń politycznych i gospodarczych oraz procesów społecznych, krytycznego podejścia do oceny przyczyn obserwowanych wydarzeń oraz wniosków uzasadniających tezę o współudziale rosyjskich służb specjalnych,

- wnikliwej interpretacji działań osłonowych i maskujących, utrudniających prawidłową identyfikację zagrożenia, między innymi w wyniku budowania przez rosyjskie służby specjalne obrazu „fałszywego agenta”, na przykład poprzez uwypuklanie prorosyjskości osób czy organizacji,

- szerszego uwzględniania kontekstu kulturowego i strategicznego działań służb specjalnych, w czym wielokrotnie przydatne okazują się odwołania do doświadczeń historycznych rosyjskich służb, w tym także w zakresie prowadzonych przedsięwzięć wsparcia $^{21}$.

\section{Agentura wpływu}

Oczywiste jest, że odpowiednia działalność związana z pozyskiwaniem informacji o tym, co się dzieje w „obozie wroga”, jest niezwykle ważna, ale wspomnieć należy o sposobach oddziaływania na przeciwnika już we wstępnej fazie działania lub planowania, czyli o wspomnianej wcześniej agenturze wpływu. Dla władzy każdego kraju równie ważna jest wiedza o potencjale i możliwościach własnego kraju, jak i podobna wiedza o przeciwniku. Doświadczenia pokazują, że tak samo istotna jest wiedza, jaki obraz o naszym kraju został stworzony w strukturach władzy i społeczeństwie innego kraju. Obraz ten jest bardzo ważny, ponieważ stanowi punkt odniesienia przy podejmowaniu wielu

19 J. Darczewska, P. Żochowski, dz. cyt., s. 52-53.

${ }^{20}$ Pozyskiwanie ze źródeł jawnych informacji, które są związane z tematyką ekonomiczną, polityczną, wojskową i wieloma innymi. Do podstawowych źródeł można zaliczyć książki, codzienną prasę, czasopisma, ogólnodostępne raporty, jak również roczniki statystyczne.

21 Tamże, s. 61-62. 
strategicznych decyzji. Zadaniem agentury wpływu jest modelowanie i kształtowanie tego obrazu, tak by odpowiadał adekwatnie przygotowanej strategii politycznej ${ }^{22}$.

Definicja amerykańska określa agenta wpływu jako osobę wykorzystywaną do dyskretnego urabiania opinii polityków, dziennikarzy i grup nacisku w kierunku przychylnym zamiarom i celom obcego państwa ${ }^{23}$. Inna definicja za agenta wpływu uważa osobę, która subtelnie i zręcznie wykorzystuje swoje stanowisko, możliwości, władzę i wiarygodność do promowania interesów obcego mocarstwa w sposób uniemożliwiający zdemaskowanie tego mocarstwa ${ }^{24}$.

Działania agentów wpływu tak charakteryzował wieloletni pracownik służb specjalnych Czesław Kiszczak: „Zadaniem agentów wpływu jest urabianie opinii publicznej lub określonych środowisk w danym kraju. Urabianie w różnym kierunku. Najczęściej chodzi o pozyskanie sympatii dla państwa, dla którego się pracuje, czasami dla służb, dla których się pracuje. Mogą też być bardziej zawiłe kombinacje, na przykład tworzenie atmosfery niechęci wobec kogoś lub czegoś".

Agent wpływu politycznego podejmuje działania w szeroko pojętym interesie własnym lub określonej grupy osób oraz oczywiście w interesie służb specjalnych, z którymi jest związany. Jego działalność jest wspierana przez organizacje funkcjonujące poza wywiadem, jednak w razie konieczności otrzymuje wsparcie struktur wywiadu klasycznego. W takim przypadku oznacza to przejście agentury wpływu na wyższy poziom, ponieważ celem jest decyzja lub decyzje na odpowiednio wysokim poziomie władzy danego kraju lub działanie związane bezpośrednio z osobą lub grupą osób, które są celem służb specjalnych. Zwykle celem tego typu działań jest zdominowanie i przejęcie kontroli nad konkretną formacją lub układem politycznym ${ }^{25}$.

Agentura wpływu to jeden z najskuteczniejszych i jednocześnie najtrudniejszych do wykrycia sposobów informacyjnego oddziaływania na przeciwnika. Osoba działająca jako agent wpływu jest odbierana w swoim bezpośrednim otoczeniu i społeczeństwie jako zwykły obywatel, który prywatnie, czasami publicznie głosi po prostu swoje poglądy. Gdy pojawia się spostrzeżenie, że są one zbieżne z linią polityczną innego kraju lub mogą wyglądać na przedłużenie działalności propagandowej tegoż kraju, przyjmuje się zwykle, że jest to po prostu zbieg okoliczności. Brak decyzji o bliższym przyjrzeniu się jego działaniom może spowodować duże szkody, szczególnie w sytuacji gdy jest on uznanym autorytetem lub wysokim urzędnikiem państwowym ${ }^{26}$.

Do najważniejszych zadań agentury wpływu należy manipulowanie opinią publiczną innego kraju poprzez rozpowszechnianie odpowiednio przygotowanych informacji, w wielu przypadkach nie do końca prawdziwych lub zniekształconych. Działanie polega również na propagowaniu opinii i chwytliwych argumentów, które powodują, że fakty

${ }^{22}$ R. Brzeski, Agentura wpływu, https://socjocybernetyka.wordpress.com/2010/01/25/dr-rafal-brzeskispecjalnie-dla-serwisu-naukowego-socjocybernetyka-pl/ [dostęp: 22.07.2018].

${ }^{23}$ N. Polmar, T.B. Allen, Księga szpiegów: encyklopedia, Magnum, Warszawa 2000, s. 14.

24 R. Brzeski, dz. cyt.

25 J. Targalski, Polityczna agentura wpływu, Strona Józefa Darskiego - Jerzego Targalskiego, https:// jozefdarski.pl/4604-polityczna-agentura-wplywu [dostęp: 22.07.2018].

${ }^{26}$ R. Brzeski, dz. cyt. 
zaczynają mieć zupełnie inne znaczenie. Zadaniem agentów jest stworzenie odpowiednich opinii w środowisku, w którym działają na co dzień, posługując się specjalnymi „technikami zarządzania postrzeganiem”, co można określić jako fałszowanie rzeczywistości. Oczywiście działalność agentury wpływu odnosi największe sukcesy w społecznościach „rozchwianych”.

Agentura wpływu jako działalność służb specjalnych nie polega na wykradaniu tajnych dokumentów lub zbieraniu informacji tajnych i poufnych, ale na rozpowszechnianiu odpowiednio przygotowanych wiadomości i opinii. Wspólnym mianownikiem z typową działalnością wywiadowczą jest proces pozyskiwania agentów. Werbowani są wśród ludzi inteligentnych, ambitnych i, co ważne, pozbawionych skrupułów, dla których najważniejsza jest kariera. W krajach anglosaskich funkcjonuje skrót MICE (pol. mysz) określający tego typu agentów, wywodzący się od słów money (pieniądze), ideology (ideologia), compromise (kompromis) oraz ego, czyli cztery najważniejsze czynniki, które mają podstawowe znaczenie przy werbowaniu agenta.

\section{Działania rosyjskich służb specjalnych w obszarze agentury w pływu}

Okres rozprzężenia i zaniku tradycyjnych więzi społecznych w okresie po I wojnie światowej stał się miejscem działań służb specjalnych ZSRR w obszarze agentury wpływu. Przyjmuje się, że pionierem tworzenia sieci agentury wpływu był Piotr Iwanowicz Raczkowski, który pełnił obowiązki szefa Agentury Zagranicznej Ochrany w Paryżu w latach 1885-1902. Jego zadaniem było regularne opłacanie francuskich dziennikarzy, którzy pisali pochlebne artykuły o rosyjskiej rodzinie carskiej oraz sytuacji gospodarczej i wewnętrznej w Rosji dla francuskich czasopism. $Z$ biegiem czasu Raczkowski zakupił specjalistyczne periodyki „Revue Russe” i „Le Courier Franco-Russe” specjalizujące się w problematyce stosunków w Europie Środkowo-Wschodniej. Założył również, tym razem przez podstawionych agentów, organizację o nazwie Liga dla Ocalenia Rosyjskiej Ojczyzny (Liguepour le Salut de la Patrie Russe, LSPR), która dzisiaj byłaby uznana za „niezależną, pozarządową formację obywatelską”. Jej zadaniem było również tworzenie wśród francuskich elit pozytywnych opinii dla carskiej Rosji ${ }^{27}$. Przed sądem stanęli również Günther Guillaume oraz Arne Treholt, ale tylko dlatego, że prowadzili równolegle „standardową” działalność wywiadowczą. Mocodawcy agenta mają oczywiście szeroki wachlarz jego obrony w razie próby zdemaskowania w postaci petycji, interpelacji parlamentarnych, akcji medialnych czy też demonstracji poparcia ze strony znanych osób.

Prawdziwym specjalistą w zakresie budowania radzieckiej agentury wpływu w Europie Zachodniej okazał się Willi Münzenberg, będący jednym z założycieli Komunistycznej Partii Niemiec i przywódca Młodzieżowej Międzynarodówki Komunistycznej. Oddziały Kominternu zakładały liczne agendy, których zadaniem było oddziaływanie na świado-

${ }^{27}$ B.B. Fisher (red.), Okhrana: The Paris Operations of the Russian Imperial Police, Central Intelligence Agency, Langley 1997, s. 7. 
mość elit polityczno-kulturalnych w różnych krajach, Münzenberg nazwał je „klubami niewiniątek”. „Musimy [...] mieć w ręku artystów i profesorów, wykorzystać teatry i kina, by szerzyć za granicą doktrynę, iż Rosja gotowa jest poświęcić wszystko, aby utrzymać pokój na świecie" - tego typu zalecenia rozpowszechniał Münzenberg. Największym jego osiągnięciem było utworzenie w 1933 roku w Paryżu Światowego Komitetu Pomocy Ofiarom Niemieckiego Faszyzmu, niezależnej organizacji pozarządowej, której sekretariat w rzeczywistości był kontrolowany przez Münzenberga i nadzorowany przez Komintern"28.

Innym doskonałym przykładem działania agentury wpływu jest okres Wielkiego Głodu na Ukrainie. Kiedy setki tysięcy osób umierało na tamtym terenie, wybitne osobistości krajów Europy zachodniej przekonywały opinię publiczną, że jest on wytworem antyradzieckiej propagandy. George Bernard Shaw zapewniał: „nie widziałem w Rosji ani jednej niedożywionej osoby: młodej lub dorosłej”, a francuski polityk, dwukrotny premier Edouard Herriot kategorycznie zaprzeczał „kłamstwom burżuazyjnej prasy, która twierdziła, że w Związku Sowieckim panuje głód"29. Moskiewski korespondent dziennika „New York Times” Walter Duranty, który za swe reportaże z Rosji otrzymał w 1932 roku Nagrodę Pulitzera, z pozycji świadka wydarzeń przekonywał, że „każde doniesienie o głodzie w Rosji jest przesadą lub złośliwą propagandą" ${ }^{\text {". }}$.

Operacje z wykorzystaniem agentury wpływu są przewidziane w wielu przypadkach na lata, ponieważ wpływ na kształtowanie świadomości grup społecznych wymaga odpowiednio długiego czasu. Skuteczność zależy od wiarygodności agentów, dlatego pomoc w awansowaniu i odpowiednim budowaniu autorytetu wymaga odpowiednio długiego czasu. Nie ma najmniejszej wątpliwości, że ocena skuteczności działania agentury wpływu jest dość trudna, ponieważ określenie efektów będzie zależało od zbyt wielu czynników. Równie trudne jest wykrycie agentów, ponieważ zlecenie ich działalności jest najpilniej strzeżoną tajemnicą. Zdemaskowany agent wpływu traci od razu swoją przydatność, dlatego jego działalność podlega maksymalnemu utajnieniu. Tego typu działanie powoduje również, że ewentualne udowodnienie przed sądem działania na rzecz obcego państwa jest niemożliwe przede wszystkim dlatego, że podstawą demokracji jest prawo do artykułowania własnych poglądów.

Można jednoznacznie powiedzieć, że przy olbrzymiej skuteczności działań podejmowanych przez służby specjalne związanych z agenturą wpływu ten rodzaj działalności jest bardzo bezpieczny dla samych agentów oraz oficerów prowadzących. Jedynym skazanym agentem wpływu jest Pierre - Charles Pathé, zwerbowany w 1959 roku $^{31}$. W 1961 roku Pathé założył agencję prasową Centred' Information Scientifique, Economique et Politique i w wydawanym biuletynie w subtelny sposób prezentował polityczną linię Kremla zgodnie z otrzymanymi wytycznymi. W późniejszym okresie był to dwutygodnik „Synthesis" poświęcony stosunkom zagranicznym oraz problemom wojskowym, naukowym

\footnotetext{
28 Tamże.

29 R. Brzeski, dz. cyt.

30 Tamże.

31 Otrzymał pseudonim Pieczerin zmieniony potem na Mason.
} 
i gospodarczym. Jak skuteczne było działanie, ukazuje fakt, że w okresie największej popularności biuletyn miał około 500 prenumeratorów, w tym 139 senatorów, 299 deputowanych, 41 dziennikarzy, 14 ambasadorów oraz zaledwie 7 osób prywatnych. Dzięki temu przygotowywane przez KGB treści docierały do 70 procent składu francuskiej Izby Deputowanych oraz 47 procent składu Senatu. Aresztowano go na gorącym uczynku odbierania honorarium i wytycznych od oficera operacyjnego paryskiej rezydentury ${ }^{32}$.

Jak wspomniano powyżej, zadaniem agentów wpływu jest sterowanie opiniami środowiska, w których na co dzień działają poprzez stosowanie odpowiednich technik zarządzania postrzeganiem. Upraszczając można powiedzieć, że podają „,na tacy” sfałszowane informacje, ale w taki sposób, by były one łatwe do przyswojenia. Wraz z rozwojem środków aktywnych w postaci agentury wpływu przyjęło się określenie pudła rezonansowe. Oznacza się w ten sposób pojedyncze osoby, publicystów, dziennikarzy, ale również polityków i różnego rodzaju instytucje, zwykle nieświadomie przekazujących dalej pozyskane łatwo informacje. Nie znając źródła pochodzenia informacji, a tym bardziej intencji, jakie były podstawą ich stworzenia, rozpowszechniają je dalej w bardzo szerokim zakresie. Motywy takiego działania to oczywiście odpowiednie profity lub po prostu poprawność polityczna. Współcześnie olbrzymie znaczenie w rozpowszechnianiu informacji mają media społecznościowe i coraz częściej pojawia się w tym kontekście określenie przypisywane Włodzimierzowi Leninowi, czyli pożyteczni idioci ${ }^{33}$. Informacje podane łatwo i przyjemnie są błyskawicznie rozpowszechniane i w niedługim czasie wiele osób, a nawet środowisk uznaje je za całkowicie prawdziwe, widząc, że są rozgłaszane przez znane im osoby.

Jak łatwo można wykorzystać ogólnodostępne media, pokazuje przykład eksperta ds. gazu i ropy naftowej Piotra Niewiechowicza, któremu udało się nawiązać kontakt z Piotrem Naimskim, pełnomocnikiem rządu ds. strategicznej infrastruktury energetycznej, oraz uzyskać informacje na temat BalticPipe, projektu gazociągu łączącego Polskę z Danią, który ma powstać w ciągu kilku najbliższych lat. Sam projekt jest oczywiście tajny i powinien się znajdować pod ochroną kontrwywiadowczą, tymczasem Piotr Niewiechowicz, jak się okazało, to postać całkowicie fikcyjna stworzona przez Piotra Maciążka i Jakuba Wiecha z serwisu Energetyka24.com za pomocą Twittera i skrzynki mailowej. Sprawa została ujawniona i była jedynie prowokacją dziennikarską, ale pokazuje, jak skutecznie można wykorzystać istniejące ogólnodostępne i, co ważne, bardzo popularne narzędzia do pozyskania tajnych informacji.

Rosyjskie służby specjalne od dziesiątek lat doskonalą narzędzia wykorzystywane w środkach aktywnych, a także szybko dostosowują sposoby działania do zmieniającej się rzeczywistości. Dzięki wykorzystaniu Internetu, odpowiednich osób, mediów zwykłych oraz społecznościowych służby są w stanie ingerować bardzo poważnie w bezpieczeństwo polityczne wybranych krajów oraz regionów. Oczywiście nie jest to informacja potwierdzona i bardzo prawdopodobne, że nigdy nie będzie, ale w coraz większym stopniu

${ }^{32}$ R. Brzeski, dz. cyt.

${ }_{33}$ Ros. поле́знытйидиот - według niektórych w ten sposób określał dziennikarzy z krajów „zachodnich” piszących w sposób wręcz entuzjastyczny o rewolucji bolszewickiej, a jednocześnie ukrywających prawdę. 
podejrzewa się, że rosyjskie tajne służby miały bardzo duży wpływ na wybór Donalda Trumpa na prezydenta USA.

Jak się okazuje, podczas trwania kampanii prezydenckiej w USA grupa Rosjan realizujących operację wpływu co minutę wysyłała w cyberprzestrzeń ogromną liczbę tweetów. Amerykańscy wyborcy otrzymali tylko w dniu 7 października 2016 roku ponad 18 tysięcy specjalnie przygotowanych i ukierunkowanych informacji. Jest to o tyle ważna data, że dokładnie w tym dniu portal Wikileaks rozpoczął publikację e-maili wykradzionych ze sztabu Hillary Clinton, które spowodowały poważne dyskusje w mediach. Administratorzy Twittera zaliczyli je w poczet grupy koordynowanej przez Państwową Agencję Badania Internetu z Sankt Petersburga, której właścicielem jest osoba związana z Władimirem Putinem. Analiza tweetów wskazuje jednoznacznie na wysoką efektywność operacji, bardzo wiele osób podawało dalej przygotowane przez Rosjan informacje. Naukowcy z Uniwersytetu Clemson po odpowiednich badaniach stwierdzili, że przeprowadzona dezinformacja wywołała bardzo szeroko zakrojone dyskusje, a o skali może świadczyć fakt, że w okresie od września do listopada 2016 roku odniesienia do kont wspomnianej Agencji pojawiły się w tweetach innych użytkowników 4,7 miliona razy ${ }^{34}$.

Podejrzewa się również, że zastosowane odpowiednie środki aktywne w znaczącym stopniu spowodowały, że Brytyjczycy zdecydowali o wyjściu z Unii Europejskiej. Służby specjalne Wielkiej Brytanii zdobyły korespondencję biznesmena Arrona Banksa, z której wynika, że utrzymywał relacje z ambasadorem Federacji Rosyjskiej w Wielkiej Brytanii, co skutkowało zaproszeniem do udziału w co najmniej trzech przedsięwzięciach biznesowych i to w okresie trwania kampanii referendalnej. Banks wspomógł kampanię LeaveUE dotacją w wysokości aż 8 milionów funtów ${ }^{35}$.

Działania Rosjan na rzecz rozbicia jedności UE są oczywiste i bardzo możliwe jest, że odpowiedni przekaz dla zwykłych obywateli państw europejskich odnośnie do emigrantów, kreowany prawdopodobnie przez służby rosyjskie, powoduje, że do władzy dość łatwo dochodzą partie i środowiska niechętne integracji. Francuska partia nacjonalistyczna Front Narodowy kierowana przez Marine Le Pen otrzymała 9 milionów euro pożyczki od mającego siedzibę w Moskwie First Czech Russian Bank. Efektem była prorosyjska polityka partii, budowanie pozytywnego wizerunku Rosji oraz prezydenta Putina przez członków ugrupowania, a w szczególności szefową partii. Na podstawie przeprowadzonych analiz pojawiają się poważne przesłanki, że rosyjskie tajne służby przy użyciu środków aktywnych ingerowały bezpośrednio w wybory prezydenckie we Francji, ale również w podobne wybory w Polsce.

Można mieć słuszne obawy, że doświadczenia rosyjskich służb i konsekwencja w ich stosowaniu mogą spowodować bardzo poważne konsekwencje w przyszłości, tym bardziej że przeciwdziałanie jest bardzo trudne. Okazuje się, że stosunkowo łatwo rosyjskie służby specjalne, posiadające odpowiednie finansowanie są w stanie znacząco naruszyć bezpieczeństwo polityczne praktycznie dowolnego kraju, ale również kruchą

${ }^{34}$ O służbach.pl, Realny wpływ Rosjan na Twittera, https://osluzbach.pl/porazajace-dane-ws-rosyjskiej -ingerencji-w-wybory-w-usa-realny-wplyw-rosjan-na-twittera/ [dostęp: 25.07.2018].

35 Tamże. 
równowagę w zakresie bezpieczeństwa międzynarodowego. Demokracja staje w obliczu poważnego kryzysu i prawdopodobnych zmian systemowych i ustrojowych, co będzie się wiązało również z koniecznością stworzenia zupełnie nowych metod zapewnienia bezpieczeństwa.

\section{Bibliografia}

Balcerowicz B., Bezpieczeństwo polityczne Rzeczypospolitej Polskiej, Akademia Obrony Narodowej, Warszawa 2004.

Baraniuk K., ,Środki aktywne” w wykorzystaniu radzieckich stużb wywiadowczych. Refleksje w kontekście kryzysu na Ukrainie, [w:] M. Górka (red.), Wywiad i kontrwywiad w polityce międzynarodowej na przełomie XX i XXI wieku, Wydawnictwo Difin, Warszawa 2016.

Born H., Unia Międzyparlamentarna i Genewskie Centrum Demokratycznej Kontroli nad Siłami Zbrojnymi. Parlamentarny nadzór nad sektorem bezpieczeństwa. Zasady, mechanizmy i praktyki, Wydawnictwo Sejmowe, Warszawa 2004.

Brzeski R., Agentura wptywu, https://socjocybernetyka.wordpress.com/2010/01/25/dr-rafalbrzeski-specjalnie-dla-serwisu-naukowego-socjocybernetyka-pl/ [dostęp: 22.07.2018].

Christopher A., Gordijewski O. (red.), More Instructions from the Centre: Top Secret Files on KGB Global Operations, 1975-1985, Frank Cass, Londyn 1992.

Crowdy T., Historia szpiegostwa i agentury, Wydawnictwo Bellona, Warszawa 2010.

Darczewska J., Żochowski P., Środki aktywne. Rosyjski towar eksportowy, „Punkt Widzenia” 2007, nr 64.

Faligot R., Kauffer R., Stużby specjalne: historia wywiadu i kontrwywiadu na świecie, Warszawa 1998.

Fisher Ben B. (red.), Okhrana: The Paris Operations of the Russian Imperial Police, Central Intelligence Agency, Langley 1997.

Górka M., Dyplomacja i wywiad. Przyczynek do refleksji nad polityka bezpieczeństwa, [w:] G. Marek (red.), Wywiad i kontrwywiad w polityce międzynarodowej na przełomie XX i XXI wieku, Wydawnictwo Difin, Warszawa 2016.

Grzegorowski Z., Instytucja „służby specjalne” a rzeczywistość funkcjonowania państwa polskiego. Wybrane zagadnienia, „Studia Gdańskie. Wizje i rzeczywistość” 2011, t. 8.

Harasimowicz A., Polska polityka bezpieczeństwa w XX i XXI wieku-niektóre dylematy (głos w dyskusji), [w:] R. Czulda, R. Łoś, J. Reginia-Zachorski (red. nauk.), NATO wobec wyzwań współczesnego świata, Instytut Badań nad Stosunkami Międzynarodowymi w Warszawie, Katedra Teorii Polityki Zagranicznej i Bezpieczeństwa - Wydział Studiów Międzynarodowych i Politologicznych Uniwersytetu Łódzkiego, Warszawa-Łódź 2013.

Kautilya, Arthaśāstra, Government Press, Bangalore 1915.

Kitler W., Bezpieczeństwo narodowe RP: podstawowe kategorie, uwarunkowania, system, Akademia Obrony Narodowej, Warszawa 2011.

Larecki J., Wielki leksykon stużb specjalnych świata, „Książka i Wiedza”, Warszawa 2007.

Liderman K., Bezpieczeństwo informacyjne, Wydawnictwo Naukowe PWN, Warszawa 2012. 
Mordaszewski K., Proces kształtowania służb specjalnych w systemie bezpieczeństwa Rzeczypospolitej Polskiej, „Przegląd Bezpieczeństwa Wewnętrznego” 2009, nr 1.

Nowak E., Nowak M., Zarys teorii bezpieczeństwa narodowego, Wydawnictwo Difin, Warszawa 2011.

O służbach.pl, Realny wpływ Rosjan na Twittera, https://osluzbach.pl/porazajace-dane-wsrosyjskiej-ingerencji-w-wybory-w-usa-realny-wplyw-rosjan-na-twittera/ [dostęp: 25.07.2018].

Ockrent Ch., Marenches A. de, Sekrety szpiegów i książąt. Relacje szefa francuskich stużb specjalnych, Wydawnictwo Editions Spotkania, Warszawa 1992.

Olszewski R., Bezpieczeństwo współczesnego świata, Wydawnictwo Adam Marszałek, Toruń 2005.

Polmar N., Allen T.B., Księga szpiegów: encyklopedia, Magnum, Warszawa 2000.

Rydlewski G., Kształt systemu instytucjonalnego bezpieczeństwa wewnętrznego w Polsce, [w:] S. Sulowski, M. Brzeziński (red.), Bezpieczeństwo wewnętrzne państwa. Wybrane zagadnienia, Dom Wydawniczy Elipsa, Warszawa 2009.

Saxe M. comte de, Mes Rêveries, Pérau, Amsterdam-Lipsk 1696-1750.

Singh N.K., Encyclopaedia of Hinduism, vol. 49, Centre for International Religious Studies 1997.

Smolski W., Cyberterroryzm jako współczesne zagrożenie bezpieczeństwa państwa,[w:] P. Fiktus P., Malewski H., Marszał M. (red.), ,, Rodzinna Europa” Europejska myśl polityczno-prawna u progu XXI wieku, E-Wydawnictwo. Prawnicza i Ekonomiczna Biblioteka Cyfrowa. Wydział Prawa, Administracji i Ekonomii Uniwersytetu Wrocławskiego, Wrocław 2015.

Stefanowicz J., Bezpieczeństwo współczesnych państw, „Pax”, Warszawa 1984.

Sulowski S., Brzeziński M. (red.), Bezpieczeństwo wewnętrzne państwa. Wybrane zagadnienia, Dom Wydawniczy Elipsa, Warszawa 2009.

Swoboda P., Co w tych stużbach jest specjalne? Problemy zwiazane ze stosowaniem pojęcia „stużby specjalne” w Polsce po 1989 r., „e-Studia nad bezpieczeństwem i terroryzmem” 2014, nr 1.

Szmulik B., Zagadnienia ogólne, [w:] M. Paździor, B. Szmulik (red.), Instytucje bezpieczeństwa narodowego, Wydawnictwo C.H. Beck, Warszawa 2012.

Targalski J., Polityczna agentura wpływu, Strona Józefa Darskiego - Jerzego Targalskiego, https://jozefdarski.pl/4604-polityczna-agentura-wplywu [dostęp: 22.07.2018].

Zalewski S., Stużby specjalne - programowanie, nadzór, koordynacja, Kancelaria Prezesa Rady Ministrów, Warszawa 2003.

Zalewski S., Strategia jako instrument bezpieczeństwa politycznego państwa, „Doctrina. Studia społeczno-polityczne" 2009, nr 6.

\section{Streszczenie „Środki aktywne” - skuteczne działania rosyjskich służb specjalnych}

Rosyjskie służby specjalne używają wielu metod, by osiągnąć stawiane przed nimi cele. Rozwój mediów, Internetu oraz szybkość rozpowszechniania się informacji spowodo- 
wały, że jednym z najważniejszych sposobów działania dla rosyjskich tajnych służb poza granicami kraju stały się środki aktywne oraz agenci wpływu. Artykuł pokazuje, jak rosyjskie służby specjalne są w stanie wpływać na sposób myślenia i podejmowanie decyzji politycznych.

Słowa kluczowe: środki aktywne, agent wpływu, służby specjalne

\section{Summary}

"Active measures" - effective operations of the Russian secret services

The Russian secret services use many methods to achieve their goals. The development of media, the Internet and the speed of dissemination of information have made "Active measures" and "Agents of influence" one of the most important means of operation of the Russian secret services abroad. The article shows how Russian secret services can influence the way of thinking and of making political decisions.

Keywords: active measures, Agent of influence, secret services 


\section{Veiling and unveiling fears in Leila Aboulela's Minaret}

The theme of veiling, or more often unveiling, features frequently in contemporary literature as the subject of discussion for both feminists and postcolonial critics. The realms represented by the scholars intermingle, especially in the present times, the times of redefinition of most meaningful values. The issue seems to be of special interest, especially in the context of physical security and emotional safety in the contemporary world. Numerous writers devote much attention to the theme of personal freedom of women representing Muslim community. One of them is Leila Aboulela, a Sudanese writer, who has gained recently much attention. The writer was born in 1964 in Cairo, Egypt where she spent her childhood. She was growing up in Khartoum, Sudan which was soon and for years effectively administered both by Egypt and England. Having gained the university degree Aboulela moved to London, and subsequently to Aberdeen for her husband's work. As the author of four novels and a collection of short stories she is categorized today mostly as a British Muslim author.

Minaret (2005) is Aboulela's second novel and the only that is placed in London. It traces the life of Najwa, born and brought up in a rich and influential Sudanese upper class family. Najwa studies at the University of Khartoum and concentrates mostly on clubbing, attending big parties in luxurious houses and travelling the world with her parents. Her future seems to be obviously promising: she aspires to the role of a wife of a rich man and a mother of beautiful children. Therefore, she neglects her education and does not pay much attention to the university degree. Soon the protagonist's beloved father turns out to be a corrupted government official and, as a result of a coup, he is executed. Najwa, her twin brother, Omar and their mother are expelled from Sudan. When still in Khartoum Najwa dated a young and rebellious student, Anwar. He was a radical socialist who used to accuse and offend Najwa's father for his fraudulent deeds. After the coup he stayed in Sudan whereas Najwa and her family escaped to London and settled in their summer 
apartment. There, unable to continue their luxurious life, they all experience failures. Omar is imprisoned for fifteen years for having drugs and trying to stab a policeman. His mother faces leukaemia and a nervous breakdown, and finally dies. Najwa, disillusioned and lonely, cut off from her father's bank accounts, loses her emotional safety and feels physically insecure.

For the first time in her life Najwa had to take up physical work. As she needed to earn money and pay bills she accepted the position of a maid and a nanny in a Muslim house of Lamya and her young daughter, Mai. In spite of the fact that she was employed as a maid Najwa used to describe herself as "a servant". Her employer, beautiful and rich Lamya, occupies the social position Najwa used to occupy in Sudan. Interestingly, the fates of Najwa and Anwar intermingle again in London. The man, as a result of another coup, was exiled to England and the couple start dating again, this time without any control from strict, Muslim protectors. Nevertheless, having learned that Anwar had no intention of marrying her, Najwa resorted to Islam and started visiting a mosque. There the protagonist finds consolation and fulfilment re-discovering her religion anew. In the meantime, Najwa begins a relationship with Lamya's younger brother, Tamar. The boy is fascinated by Najwa's devotion to Islam as he himself is a devout Muslim. He intends to marry Najwa which appears to be a shocking discovery for his mother and sister. Tamar's mother offers Najwa a meaningful sum of money. The protagonist in return is obviously to abandon her son and finish the embarrassing relationship. Surprising as it may seem, Najwa accepts the money in order to fulfil her biggest dream: she intends to go on hajj.

The novel touches upon a number of meaningful issues, among them being the dislocation and loneliness of a young Sudanese woman in a big city. The feelings accompanying young Najwa are reflected in the opening lines:

I've come down in the world. I've slid to a place where the ceiling is low and there isn't much room to move. Most of the time I'm good. I accept my sentence and do not brood or look back. But sometimes a shift makes me remember. Routine is ruffled and a new start makes me suddenly conscious of what I've become $[\ldots]^{1}$.

The alienation and lowered social position disturb Najwa at the beginning. She feels lost and uncontrolled by rules of Islam, her parents and the laws of the country. Unexpected redefinition of her life is difficult as the protagonist is not a daughter any more, not a wife, or even not an attractive woman she used to be. Walking alone in the streets of London she perceives herself as transparent, invisible and unimportant.

The fact that Najwa was left alone in a big and unfriendly city evoked her fear and distress. She feels culturally and geographically displaced and she cannot avoid the feeling that she should not be in a restaurant alone: "I felt silly sitting all by myself, self-conscious" After her mother's death the character discovers that she could order a glass of wine in a restaurant or buy a pornographic magazine and nobody would be surprised or nobody would even care. This freedom, however appears to be disturbing and annoying. Najwa feels unprotected and neglected as there is nobody to look after her.

\footnotetext{
${ }^{1}$ L. Aboulela, Minaret, Bloomsbury, London 2005, p. 1.

${ }^{2}$ Ibidem, p. 128.
} 
The employment she took up does not guarantee her financial satisfaction or security. From the very beginning she is afraid she might lose the job. Therefore, she tries to be invisible and deferential:

I take off my coat, fold it and put it over my shoes - it wouldn't be polite to hang it over the family's coats on the coat-rack. I know I must be careful in everything I do; I mustn't slip. The first day is crucial, the first hours. I will be watched and tested $[\ldots]^{3}$.

The state of insecurity and unstable emotional and financial situation make Najwa search for deeper and more meaningful things in her life. She recognized her identity as blurred, weak and disturbed. In the world of fast cars, determined, well educated women she felt abandoned and lonely.

She had never been a religious person and when her mother died she seemed helpless. She found it impossible to organize a funeral and, surprised, she discovered that there are some women who helped her gratuitously. Observing the women in the mosque Najwa discovered that they seemed to have access to something she missed but was never aware of, that is faith. It was religion that became their identity, not their national belonging or ethnicity. In the mosque Najwa encountered a number of women representing various cultural and ethnic backgrounds. They were all united by Islam and the sense of purpose. They represent, what Anna Ball calls in her article on diasporic experience, "faith-based identity and community"4.

Although Muslim by tradition, Najwa had never paid attention to religion when in Khartoum. Hardly ever did she pray or visit a mosque. Minaret presents, in Anna Ball's view, "the journey from securely rooted national belonging into marginality, assimilation or hybridity" that the protagonist faced in London. The woman, therefore, begins personal journey in order to discover her real identity. Interestingly, Aboulela endeavours to convince a reader that "religious identity provides more stability than national identity". Obviously, there are numerous sources of identity. The issue of belonging applied by Aboulela, so closely connected with postcolonial studies, seems to be more complicated in case of religious identity. Is identity always connected with belonging? Does one have to belong to discover his/her identity? The author does not give simple answers but, undoubtedly, the reader witnesses the process of coming back to faith which turned out to be "a never ending but fascinating journey of painful surrender but also numerous discoveries"

In spite of the fact that Najwa had never been an ardent Muslim there was something intriguing for her when she observed young girls covering their heads in Sudan: "I remember the girls in Khartoum University wearing hijab and those who covered their hair with white tobes. They never irritated me, did they?"8. Even though her boyfriend,

3 Ibidem, p. 81.

4 A. Ball, ,Here is where I am”. Rerooting diasporic experience in Leila Aboulela's recent novels, [in:] J.Wilson (et al.), Rerouting the Postcolonial, Routeldge, London 2010, p. 118.

5 Ibidem, p. 120.

${ }^{6}$ A. Sethi, Keep the Faith, www.observer.co.uk [accessed June 5, 2005].

7 A. Stanecka, Re-positioning of religious functions in Leila Aboulela's “Minaret”, [in:] E. Krawczyk-Neifar, Modern Languages and Culture, WSZOP, Katowice 2016, p. 111.

${ }^{8}$ L. Aboulela, Minaret, op. cit., p. 134. 
Anwar, and her best friend, Randa, despised the girls for being backward and conservative, the protagonist never felt that way. Unfortunately, for many years the character was deprived of "guidance and wisdom, [...] grace and forgiveness" so closely connected by Leila Aboulela with religion?. In Sudan there were other things more intriguing for the young girl. She was "an emancipated young woman driving her own car to university" Later, her life in London, without emotional and financial support of her relatives, will be turned towards a different direction.

The protagonist of Minaret is frequently called Aboulela's alter ego. The author admits that religion is extremely important and influential in her personal life and literary output. She applied her own perspective to create literature describing the clash between modernity and tradition. What is more, Aboulela also mentions women in her family as most meaningful in shaping her Muslim identity:

My faith was started off by my grandmother and mother and so I always saw it as a very private, personal thing [...]. At the same time, they were very progressive. My grandmother studies medicine in the Forties, which was very rare in Egypt, and my mother was a university professor, so my idea of religion wasn't about a woman not working or having to dress in a certain way; it was more to do with the faith ${ }^{11}$.

What brought the sense of spiritual safety to Aboulela was cogency and restraint she discovered in Islam. She claims that in Muslim religion she encountered "spiritual journeys, and familiar depictions of the rigor and patience needed to discipline the ego"12, but, as she writes, she would never call it oppression or subjection. The message Aboulela tries to vocalize in the novel is that "boundaries can be comforting and nurturing" and "freedom does not necessarily bring happiness"13.

Leila Aboulela is one of few authors who publicly admits the weight of religion in her life. What is even more meaningful, she claims that only after the arrival to England did she start wearing hijab. Contrary to what many people might assume, the author felt in England unrestricted possibility of choice and, after painful geographical dislocation, the rebirth of religious emotions: "I didn't know anybody. It was 1989 and the word "Muslim" wasn't even really used in Britain at the time; you were either black or Asian. So then I felt very free to wear the hijab"14. Interestingly, she states that in Khartoum her "personality was shy and quiet and [she] wanted to wear hijab but didn't have courage, as [she] knew [her] friends would talk [her] out of it" ${ }^{15}$.

The author's experiences are reflected in the protagonist of Minaret who begins as a lighthearted and untroubled student, and finishes as a devout Muslim. Her transformation happens slowly but steadily, and it begins with smell and childhood memories:

\footnotetext{
9 L. Aboulela, Restraint? Sure. Oppression? Never, www.washingtonpost.com [accessed July 22, 2007 ].

${ }^{10}$ L. Aboulela, Minaret, op. cit., p. 10.

11 A. Sethi, Keep the Faith, www.observer.co.uk [accessed June 5, 2005].

12 L. Aboulela, Restraint? ..., op. cit.

13 Ibidem.

14 A. Sethi, op. cit.

15 Ibidem.
} 
I close my eyes. I can smell the smells of the mosque, tired incense, carpet and coats. I doze and in my dream I am small and back in Khartoum, ill and fretful, wanting clean, crisp sheets, a quiet room to rest in, wanting my parents' room, wanting to get up and go to my parents' room. Men's voices come from downstairs, a low rumble, a cough. I wake up and the cough reminds me of my father, the dream of my parents' room ${ }^{16}$.

Positive connotations bring Najwa again to the mosque. She admires the women, their beauty and the way they tie their scarves on their hair. The protagonist remembers that in her family house in Sudan the only religious people were the servants. When she visited her friend Randa, the latter earnestly criticised girls wearing hijabs, claiming that it is impossible to work dressed like this and that the girls wearing chadors take their culture back to the Middle Ages ${ }^{17}$. But when Najwa is left alone in London she discovers her heritage anew, independently and she seems to be seduced by it.

When asked, after her mother's death, whether she prays, Najwa answers in a negative way:

I had learnt to pray as a child. I had prayed during Ramadan, during which I fasted mostly in order to lose weight and because it was fun. I prayed during exams to boost my grades. I liked wearing my mother's white tobe, feeling the material around me. I liked feeling covered, cosy. But I had often bobbed up and down, not understanding what I was saying, impatient to get the whole thing over with ${ }^{18}$.

When the girl started visiting the mosque everything changed and she felt the need to expand her knowledge of Islam. She recalled the students in Sudan resorting to their tradition and their prayer. She admired the girls wearing colourful tobes. But most of all, she was impressed by the view of praying students who looked peaceful and happy. One of them was reciting the Qur'an in "an effortless, buoyant style". Najwa looked at the tobes of the students, "the spread of colours, stirred by occasional gust of wind"19. When her attention was distracted by her boyfriend, she got angry and irrationally jealous of the praying students. What was she experiencing? "I envied them something I didn't have but I didn't know what it was. I didn't have a name for it" ${ }^{20}$. This unexplained situation evoked anxiety and the feeling of uneasiness which later accompanied the girl in London. She felt empty, unaware and deprived of something meaningful.

The protagonist frequently describes her acting on hearing muezzin calling for prayer: “whenever I heard the Qur'an recited I would feel a bleakness in me and a depth and space would open up, hollow and numb. I usually didn't notice it, wasn't aware that it existed" 21 . When she was driving her luxurious car the words of prayer heard on the radio "would tap at this inner sluggishness, nudge it like when my feet went to sleep and

\footnotetext{
16 L. Aboulela, Minaret, op.cit., p. 74-75.

17 Ibidem, p. 29.

18 Ibidem, p. 160.

19 Ibidem, p. 43.

20 Ibidem, p. 134

${ }^{21}$ Ibidem.
} 
I touched them"22. All the incomprehensible things do not allow Najwa to forget about the fear of something undetected.

What is more, the woman realizes that the visits in a mosque gave her a new perspective. She became aware of the fact that her conversion was not accidental: "My guides chose me; I didn't choose them [...]. The words were clear, as if I had known all this before and somehow, along the way, forgotten it" ${ }^{\prime 23}$. The more she learned, the more she wanted to discover. She seemed to be hungry for knowledge: "Teach me something old. Shock me. Comfort me. Tell me what will happen in the future, what happened in the past. Explain to me. Explain to me why I am here, what am I doing. Explain to me why I came down in the world. Was it natural, was it curable?"24. Unaware of the meaning of the faith in the past, Najwa now poses difficult and challenging questions. She wants to know more in order to discover her identity.

The decision to convert was complex and it took the protagonist much time to make it consciously. Nevertheless, there was even more difficult battle to be conducted as Najwa decided to surrender and cover her head and the whole body. Rafia Zakaria in her book entitled Veil poses important questions concerning the reasons for wearing hijab:

Are our choices, represented by the literal actions we take, the physical picking up of an object such as the veil and its putting on, or at these snapshots of decisions culminations of an ever larger and more involved webs of considerations - a previous experience, a parent's love, a lover's command, a friend's insistence whose collective congruence is sometimes reflected in what we wear or how we choose to appear? ${ }^{25}$.

In Najwa's case it resulted rather from a long-lasting process of consideration and hesitance. The latter resulted from fear: but it was not only the concern about being unaccepted by western society, because as Kate Zabrin asserts, "the covering of the body goes directly against mainstream British (and Western) culture in a dramatic and visible way" ${ }^{26}$. It was also the fear of unaccepting the reflection in the mirror. The young woman was afraid she might look strange or ugly in a scarf covering her hair. Naomi Wolf in The Beauty Myth claims that "both women and men [are] accustomed to having beauty evaluated as wealth" 27 . The leading character in the story always paid much attention to her appearance confirming Wolf's statement that "women are mere 'beauties' in men's culture so that culture can be kept male" 28 . Roger Scruton in his book entitled Beauty confirms that attractive appearance and desire go together and, undoubtedly, "beauty pleases us" and "distinctive beauty of the human body derives from its nature" 29 . Although there is no gendered stereotyping in religion Najwa hesitates and is afraid of losing her

22 Ibidem.

23 Ibidem, p. 240.

24 Ibidem.

25 R. Zakaria, Veil, Bloomsbury, London 2017, p. 25.

${ }^{26}$ K. Zebiri, British Muslim Converts:Choosing Alternative Lives, One World Publications, Oxford 2008, p. 204.

27 N. Wolf, The Beauty Myth, Vintage Books, London 2015, p. 15.

28 Ibidem, p. 31.

29 R. Scruton, Beauty, Oxford University Press, Oxford 2009, p. 41. 
attributes. Similarly, Leila Aboulela admits that wearing a scarf on her head "came after years of hesitation, years during which [she] held back out of fear that [she] would look ugly in a head scarf'30.

Finally, Najwa makes an attempt to wear a scarf. First, unsuccessful trial does not discourage the protagonist. She struggles with her hair and her will:

I stood in front of the mirror and put the scarf over my hair. My curls resisted; the material squashed them down. They escaped, springing around my forehead, above my ears. I pushed them back, turned my head sideways to look at the back and it was an angular hump, a bush barely covered with cloth. The cotton scarf was almost a threadbare ${ }^{31}$.

The woman is a bit shocked with her reflection: "I didn't look like myself", she thought. The character is convinced that something was "removed, streamlined, restrained" 32 . Anna Ball sums up that the protagonist's adoption of hijab was simply "a gesture towards modesty and a marker of her femininity" 33 but it proves something more meaningful. As Kate Zebiri quotes after Myfanwy Franks, "in order to wear Islamic dress in Britain today, [women] have to be bold and intrepid"34. The woman, therefore, demonstrates her courage and the desire to feel comfortable and safe, in spite of geographical dislocation she experiences.

So after a number of attempts determined Najwa tries on her mother's old tobe:

I tied my hair back with an elastic band, patted the curls down with pins. I wrapped the tobe around me and covered my hair. In the full-length mirror I was another version of myself, regal like my mother, almost mysterious. Perhaps this was attractive in itself, the skill of concealing rather than emphasizing, to restrain rather than to offer ${ }^{35}$.

This time Najwa was satisfied and she accepted her appearance. That was the end of her long and painful journey towards her newly composed self. She escaped from the world of corruption and temptation and resorted to Islam and her new, veiled identity.

Najwa's spiritual journey and development were over. Earlier, the protagonist experienced humiliation while walking in London and being provoked by men working in the street. She recollects hearing "a whistle and a laugh as one of them shouted something". Though she did not understand the man, she "understood the tone", "flushed, aware that all the weight [she] had gained settled on [her] hips" ${ }^{36}$. When she was veiled she decided to walk the same street and this time there was no sound, the men ignored her completely and avoided her eyes. The same moment she felt invisible and unimportant but happy and fulfilled as she discovered the secret of modesty and surrender to Allah.

Wearing traditional Islamic dress does not always assure physical security. The protagonist of the novel becomes an object of assault when she travels back home on a night bus. Teenagers who spotted her wearing a scarf make fun of her, throwing different objects

${ }^{30}$ L. Aboulela, Restraint? ..., op. cit.

31 L. Aboulela, Minaret, op.cit., p. 245.

32 Ibidem.

33 A. Ball, Here is where I am ..., op. cit., p. 123.

${ }^{34}$ M. Franks, [in:] K. Zebiri, British Muslim Converts: Choosing Alternative Lives, One World Publications, Oxford 2008, p. 207.

35 L. Aboulela, Minaret, op. cit., p. 246.

${ }^{36}$ Ibidem, p. 130. 
at the back of her head. "You Muslim scum", she heard, "then the shock of cool liquid on [her] head and face" ${ }^{37}$. The boys laugh and humiliate her, but she leaves the bus stronger and even more determined to follow her way. Although her safety was challenged, she felt protected by her faith as she was praying all the time on the bus. Interestingly, Kate Zebiri proves that the hostility towards women wearing hijab could be explained by the fact that "it subverts a long-standing tradition in Western culture which assigns to women the role of being looked at, of being evaluated and enjoyed visually, by men in particular, but also by other women" 38 . Leaving the bus resolute, Najwa made a significant spiritual development.

Wearing hijab became a sort of salvation for the woman. In Zebiri's view, women who start wearing traditional clothes "report a heightened sense of self-confidence and selfesteem [...] arising in part from a sense that they are now treated as a person rather than as a 'sex-object', and also from the fact that they are no longer dressing to please men" 39 . The protagonist feels happy and released from the necessity to look attractive for men. She also feels safe as the comforting size of the scarf covers her hair. Arimbi claims that one of well-founded reasons for wearing hijab in the past "was to protect Muslim women against men's harassments" ${ }^{40}$. In Abouela's novel, however, covered female body is not the symbol of resistance but rather nurturing power that comes directly from transparent doctrines of Islam. Arimbi confirms that "veiling grants women security and protects them against men's lust" 41 but in Najwa's case, it is more about following the rules of the Qur'an, about being modest and spiritually liberated. Amrit Wilson confirms the fact that since "women's bodies are endlessly and relentlessly sexualised, many Muslim women choose to wear the hijab to establish their own boundaries and their own space"42. Najwa additionally endeavours to present her religious position by stating that her body is not to be objectified or treated impersonally but that it became the symbol of her conversion and re-discovered faith. Najwa unveiled her fears and anxieties in order to veil her face and body.

\section{Bibliography}

Aboulela L., Minaret, Bloomsbury, London 2005.

Aboulela L., Restraint? Sure. Oppression? Never, www.washingtonpost.com [accessed July 22, 2007].

Arimbi D.A., Reading Contemporary Indonesian Muslim Women Writers, Amsterdam University Press, Amsterdam 2009.

Ball A., ,Here is where I am”. Rerooting diasporic experience in Leila Aboulela's recent novels, [in:] J.Wilson (et al.), Rerouting the Postcolonial, Routeldge, London 2010.

${ }^{37}$ Ibidem, p. 81.

${ }^{38}$ K. Zebiri, op.cit., p. 205.

${ }^{39}$ Ibidem, p. 207.

40 D.A. Arimbi, Reading Contemporary Indonesian Muslim Women Writers, Amsterdam University Press, Amsterdam 2009, p. 34.

${ }^{41}$ Ibidem, p. 38.

${ }^{42}$ A.Wilson, Dreams, Questions, Struggles: South Asian Women in Britain, Pluto Books, London 2006, p. 22. 
Scruton R., Beauty, Oxford University Press, Oxford 2009.

Sethi A., Keep the Faith, www.observer.co.uk [accessed June 5, 2005].

Stanecka A., Re-positioning of religious functions in Leila Aboulela's “Minaret”, [in:] E. Krawczyk-Neifar, Modern Languages and Culture, WSZOP, Katowice 2016.

Wilson A., Dreams, Questions, Struggles: South Asian Women in Britain, Pluto Books, London 2006.

Wolf N., The Beauty Myth, Vintage Books, London 2015.

Zakaria R., Veil, Bloomsbury, London 2017.

Zebiri K., British Muslim Converts: Choosing Alternative Lives, One World Publications, Oxford 2008.

\section{Streszczenie}

\section{Zakrywanie i odkrywanie strachu wowieści Minaret Leili Abouleli}

Powieść Leili Abouleli Minaret przedstawia losy młodej Sudanki, która w efekcie zamachu stanu wraz z matką i bratem musi opuścić kraj i osiada w Londynie. Podczas gdy w Sudanie Najwa reprezentowała wyższą klasę społeczną, w Londynie, po śmierci matki i uwięzieniu jej brata za posiadanie narkotyków, dziewczyna podejmuje pracę zarobkową. Czuje się zagrożona realiami wielkiego miasta, brakiem pieniędzy i męża, który w kulturze wschodniej przejmuje rolę opiekuna kobiety, nadmierną wolnością. Jest jeszcze strach emocjonalny wywołany tęsknotą za czymś niewyjaśnionym. Tym czymś okazuje się wiara, która staje się dla Najwy wybawieniem. Co ciekawe, bohaterka z czasem decyduje się założyć hidżab, co w kulturze Islamu oznacza skromność i poddanie Allahowi. We współczesnym Londynie Najwa czuje się bowiem bezpieczniej z zakrytym ciałem niż z odkrytym.

Słowa kluczowe: strach, bezpieczeństwo, kobieta, welon, studia postkolonialne, religia

\section{Summary}

\section{Veiling and unveiling fears in Leila Aboulela's Minaret}

Leila Aboulela's Minaret presents the life of a young Sudanese woman, who was expelled after a coup in the country. Together with her brother and mother she moves to London. In Sudan she was part of the higher social class but in London, after her mother's death and her brother's imprisonment, she needs to work and earn money. She feels endangered by contemporary London realities, lack of financial security, lack of a husband, who in eastern culture takes the role of a protector. She is also overwhelmed with the freedom she unexpectedly has in London. There is also emotional anxiety evoked by something unexplained which appears to be faith. Interestingly, with time the protagonist decides to wear hijab which, in Islamic culture, denotes modesty and surrender to Allah. It turns out that in contemporary London Najwa feels more secure when she is veiled rather than unveiled. Keywords: fear, security, a woman, veil, postcolonial studies, religion 


\section{Znaczenie logistyki w zarządzaniu kryzysowym}

W potocznej świadomości społecznej bezpieczeństwo jest utożsamiane z szeroko pojętą stabilizacją i przebiega dwutorowo, czyli w wymiarze osobistym, indywidualnym (sytuacja socjalna, zdrowotna, zawodowa, rodzinna) oraz publicznym, co z kolei jest łączone między innymi z ogólną sytuacją państwa jako całości (gospodarczą, polityczną, społeczną), jego zdolnością do realizacji wielowymiarowych celów i obowiązków względem obywateli. Wyznacznikiem bezpieczeństwa jest zarówno aspekt militarny, czyli liczebność armii danego kraju, posiadany rodzaj uzbrojenia, jego jakość, ilość, mobilność, zdolność bojowa, zawierane sojusze na arenie międzynarodowej, przynależność do różnorodnych organizacji polityczno-wojskowych, takich jak Pakt Północnoatlantycki (NATO), aspekt gospodarczo-polityczny, między innymi członkostwo w Unii Europejskiej (UE), skuteczność prowadzonych negocjacji w obszarze dyplomacji, uwarunkowania geopolityczne, jak i szeroko pojęte zabezpieczenie logistyczne poszczególnych obszarów i gałęzi gospodarki, w tym tych o znaczeniu strategicznym, jak na przykład energetyka, transport publiczny, złoża naturalne, ośrodki badawczo-rozwojowe, dobra narodowe, instytucje pożytku publicznego, w tym szkoły, instytucje rządowe i samorządowe oraz wiele innych.

Głównym celem niniejszego artykułu jest próba zobrazowania istoty i znaczenia logistyki,jej implementacji w warunkach kryzysowych wpływających na stan bezpieczeństwa podmiotów gospodarczych i społecznych oraz naświetlenie podstawowych zadań logistyki w sytuacjach kryzysowych. W przedstawionej pracy założono hipotezę, że: logistyka pozytywnie wpływa na efektywność podejmowania decyzji w warunkach kryzysowych. Zastosowaną metodę badawczą stanowiła analiza systemowa wykorzystywana zwłaszcza w naukach społecznych. Analiza systemowa jest to „dziedzina wiedzy dotycząca poznania układów organizacyjnych i sposobów ich działania. Umożliwia łączenie dorobku różnych dziedzin nauki wokół wybranych problemów. Ma charakter interdyscyplinarny i syntetyzujący, służąc projektowaniu przyszłych struktur i działań w oparciu o kryteria 
sprawnościowe. Doskonali i upowszechnia skwantyfikowane metody analizy, wykorzystując metodę modelowania matematycznego i teoretyczne konstrukcje odzwierciedlające w uproszczony sposób rzeczywistość. Badania operacyjne stanowią podstawę analizy systemowej"1. Wybrana metoda badawcza w naturalny sposób wpasowuje się w obszar poruszanej problematyki logistyki bezpieczeństwa, w której wdrażane i realizowane procesy logistyczne stanowią system wzajemnie wpływających i zależnych od siebie elementów (podsystemów). Odpowiednie zabezpieczenie logistyczne warunkuje zdolność poszczególnych organizacji publicznych i prywatnych do planowego wypełniania celów, misji i zadań im przypisanych w przewidywanych ramach czasowo-przestrzennych i wybranych kanałach komunikacyjnych. Logistyka i jej gałęzie, w tym logistyka bezpieczeństwa, stały się podstawą, na której organizacje opierają swoją egzystencję w wymiarze praktycznym. Ugruntowana pozycja logistyki w sytuacjach kryzysowych świadczy o jej zdolnościach adaptacyjnych do coraz bardziej zmiennego, dynamicznego otoczenia i związanych z tym zagrożeniach mogących w poważnym stopniu zakłócić lub uniemożliwić podejmowanie decyzji i działań dających wartość dodaną dla jej odbiorców.

\section{W prowadzenie do logistyki bezpieczeństwa}

\subsection{Wybrane definicje logistyki $i$ jej istoty}

Zdefiniowanie pojęcia logistyki jest procesem bardzo złożonym ze względu na wieloznaczność sformułowań, w tym liczbę głoszonych koncepcji, poglądów i przemyśleń zarówno teoretyków, jak i praktyków mających kompetencje zawodowe i naukowe z tego obszaru wiedzy. Pojęcie logistyka ma swój źródłosłów w języku greckim i pochodzi od określeń: logos (słowo, wiedza, liczenie), logiamos (obliczanie, kalkulacja, rachunek), logistes (rachmistrz), logistikon (rozum, rozsądek), logistike (sztuka liczenia, kalkulowania) ${ }^{2}$. W opinii Krzysztofa Ficonia definicję logistyki można rozpatrywać w trzech aspektach: funkcjonalnym - jako ogólny proces zarządzania, który obejmuje: planowanie, organizowanie, motywowanie i kontrolowanie, przedmiotowym - jako fizyczne przepływy materiałów, towarów i usług oraz informacji, mających miejsce między dostawcami a odbiorcami, a także ocenowym - jako efektywny proces gospodarczy nakierowany na zaspokojenie potrzeb klienta ${ }^{3}$. Powyższe wnioski wynikają z przeprowadzonej przez autora analizy pojęć logistyki, sformułowanych przez liczne autorytety z tej dziedziny, między innymi M. Christophera i J. Webera.

„Logistyka obejmuje fizyczne procesy przepływu surowców, materiałów i produktów od naturalnych źródeł ich pozyskania aż do końcowych ogniw konsumenckich, które za-

${ }^{1}$ Stownik pojęć ekonomicznych, s. 17, [za:] Encyklopedia Zarządzania, Analiza systemowa, https://mfiles. pl/pl/index.php/Analiza_systemowa [dostęp: 6.10.2018].

${ }^{2}$ S. Abt, H. Woźniak, Podstawy logistyki, Uniwersytet Gdański, Gdańsk 1993, s. 18; D.M. Lambert, J.R. Stock, Strategic Logistics Management, R.D. Irwin, Inc. Homewood, Illinois 1993, s. 4, [za:] K. Ficon, Procesy logistyczne w przedsiębiorstwie, Impuls Plus Consulting, Gdynia 2001, s. 11.

${ }^{3}$ K. Ficoń, dz. cyt., s. 35. 
spokajają potrzeby produkcyjne podmiotów gospodarczych i konsumpcyjne gospodarstw indywidualnych i zbiorowych"4. W opinii Elżbiety Gołembskiej nazwa logistyki wywodzi się z XVI wieku i oznacza kto logicznie myśli $i^{5}$. Działalność logistyczna na przestrzeni lat przeszła wiele przeobrażeń, od działań fragmentarycznych mających miejsce w latach 50. i wczesnych 60., poprzez fazę fizycznej dystrybucji w latach 70., do zintegrowanego działania, które nastąpiło w latach 80 ., wówczas logistyka stała się profesjonalną dziedziną wiedzy, natomiast w latach 90. na powstałej bazie zintegrowanych działań narodziła się koncepcja zarządzania łańcuchem dostaw, w ramach której uwzględnia się źródła surowców oraz dostawców, politykę zakupu i gromadzenia surowców, przepływ materiałów wewnątrz firmy, przechowywanie wyrobów gotowych, dystrybucję, magazynowanie, a także transport ${ }^{6}$. „Logistyka to proces zarządzania całym łańcuchem dostaw”7 . Amerykańskie Stowarzyszenie Marketingu (AMA) w 1948 roku określiło logistykę jako ruch oraz operowanie produktami z miejsc wytworzenia do miejsc konsumpcji ${ }^{8}$, natomiast członkowie Towarzystwa Logistycznego (CLM) zdefiniowali logistykę jako: „proces planowania, sterowania i kontroli kosztów, przepływu i magazynowania oraz informacji - od źródeł wydobycia surowca aż do miejsca konsumpcji produktu, zgodnie z życzeniami klienta”9. Zdaniem Andrzeja Szymonika „Logistyka jest interdyscyplinarną dziedziną wiedzy (oprócz własnego dorobku korzysta ona z nauk technicznych, wojskowych, matematycznych, ekonomicznych, w tym o zarządzaniu), której przedmiotem badań są prawidłowości i zjawiska występujące podczas przepływu dóbr i informacji na całej długości łańcucha dostaw"10.

Stowarzyszenie Logistyków Amerykańskich (Council of Logistics Management) zaproponowało następującą definicję logistyki: „Logistyka to proces planowania, realizowania i kontrolowania sprawnego i efektywnego ekonomicznego przepływu surowców, materiałów do produkcji, wyrobów gotowych i usług oraz odpowiedniej informacji z punktu pochodzenia do punktu konsumpcji w celu zaspokojenia wymagań klienta"11.

Europejskie Stowarzyszenie Logistyków (European Logisticis Association) określiło definicję logistyki następująco: „Logistyka jest pojęciem obejmującym organizację, planowanie, kontrolę i realizację przepływu towarów z miejsc ich wytworzenia (zakupu), poprzez sferę produkcji, dystrybucji, aż do finalnego odbiorcy, której celem jest zaspokojenie potrzeb rynku, przy minimalnych kosztach i minimalnym zaangażowaniu kapitału"12. Logistyka poprzez swą uniwersalność i adaptacyjność do otoczenia odnalazła zastosowanie we wspomnianych już naukach technicznych, ekonomicznych, matematycznych i wojskowych, skąd wzięła swój początek i zastosowanie.

\footnotetext{
4 Tamże, s. 48.

${ }^{5}$ E. Gołembska, Istota logistyki, podstawowe pojęcia, [w:] E. Gołembska (red.), Kompendium wiedzy o logistyce, Wydawnictwo Naukowe PWN, Warszawa 2007, s. 17.

6 Tamże.

7 Tamże, s. 18.

8 Tamże.

9 Tamże.

${ }^{10}$ A. Szymonik, Logistyka i zarządzanie łańcuchem dostaw, cz. 1, Wydawnictwo Difin, Warszawa 2010, s.18.

11 Tamże, s. 17.

12 Tamże, s. 17-18.
} 


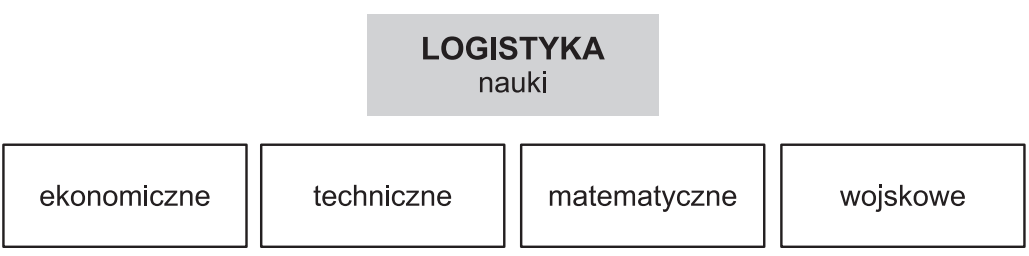

Rysunek 1. Logistyka jako interdyscyplinarna dziedzina wiedzy

Źródło: opracowanie własne.

Logistyka stanowi dziedzinę nauki zajmującą się zarządzaniem przepływem surowców, materiałów, wyrobów gotowych i informacji ${ }^{13}$. Logistyka to: „Zarządzanie procesami przemieszczania dóbr i/lub osób oraz działaniami wspomagającymi te procesy w systemach, w których one zachodzą"14. Przytoczone definicje w oczywisty sposób nie wyczerpują całej gamy pojęć logistyki znajdujących się w publicznym obiegu, lecz pozwalają przybliżyć jej postrzeganie z różnych punktów widzenia i szerokości geograficznych. Zakres logistyki obejmuje: zarządzanie informacją, zarządzanie transportem, zarządzanie materiałami, zarządzanie magazynowaniem, zarządzanie bezpieczeństwem, zarządzanie pakowaniem ${ }^{15}$, natomiast ze względu na obszar działania logistykę dzielimy na: mikrologistykę, zajmującą się procesami logistycznymi zachodzącymi w obrębie pojedynczego przedsiębiorstwa, mezologistykę, zajmującą się procesami logistycznymi, które zachodzą W obrębie pojedynczego działu gospodarki, makrologistykę, zajmującą się procesami logistycznymi mającymi miejsce w obrębie całej gospodarki krajowej, eurologistykę obejmującą zasięgiem kontynent europejski oraz logistykę globalną obejmującą swoim zasięgiem cały świat ${ }^{16}$.

13 Governica, Encyklopedia, https://www.governica.com/Logistyka [dostęp: 16.06.2018].

${ }^{14}$ Logistyka.net.pl, Stownik logistyczny, https://www.logistyka.net.pl/slownik/main?start=0\&keyword $=$ logistyka [dostęp: 16.06.2018].

15 Governica, Encyklopedia, dz. cyt.

16 Tamże. 


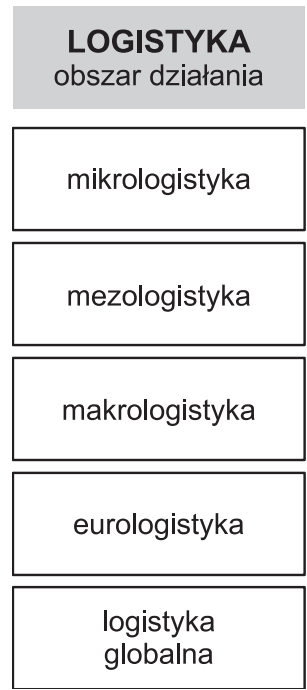

Rysunek 2. Podział logistyki ze względu na obszar działania

Źródło: opracowanie własne.

Do kluczowej działalności logistycznej zaliczamy: standaryzację produktów i usług (określenie życzeń i potrzeb klienta, projekt produktu, usługi, prognoza sprzedaży, zarządzanie jakością, tworzenie logistycznego systemu informacji), działalność transportową (wybór gałęzi trasy, wybór technologii przewozu, rozkład jazdy, wyposażenie, koszty transportu), zarządzanie zapasami (wybór lokalizacji baz, liczba i wielkość magazynów, liczba pozycji asortymentów, rotacja zapasów, poziom zapasów bezpiecznych), proces zamówień (wybór liczby dostawców, otwarcie i przyjęcie zamówień, określenie form zamówień, przygotowanie zamówień, realizacja zamówień) ${ }^{17}$. Do pomocniczej działalności logistycznej zaliczamy: systemy informatyczne (gromadzenie informacji do bazy danych i bazy wiedzy, tworzenie systemów ewidencji i sprawozdawczości, sieci lokalne i rozległe, systemy doradcze, systemy eksperckie), współpracę z produkcją (tworzenie partii dostaw, rodzaj i czas przygotowania wysyłek, opakowanie transportowe, dyspozycja ruchem pojazdów, jednostki ładunkowe), magazynowanie i obsługa zapasów (wyznaczanie powierzchni magazynu, rozmieszczenie zapasów w magazynie, wyposażenie magazynów, oznakowanie miejsc magazynowych, kompletacja i dekompletacja), a także zaopatrzenie (kierunki dostaw, wielkość zakupów, źródła zakupów, wielkość powtarzalnych zakupów, częstotliwość dostaw) ${ }^{18}$.

Rysunek 3 ilustruje główną działalność logistyki obejmującą między innymi transport, zarządzanie zapasami oraz jej formę pomocniczą, w skład której wchodzą systemy informatyczne, współpraca z produkcją, magazynowanie i obsługa zapasów oraz zaopatrzenie.

17 E. Gołembska, dz. cyt., s. 22.

18 Tamże. 


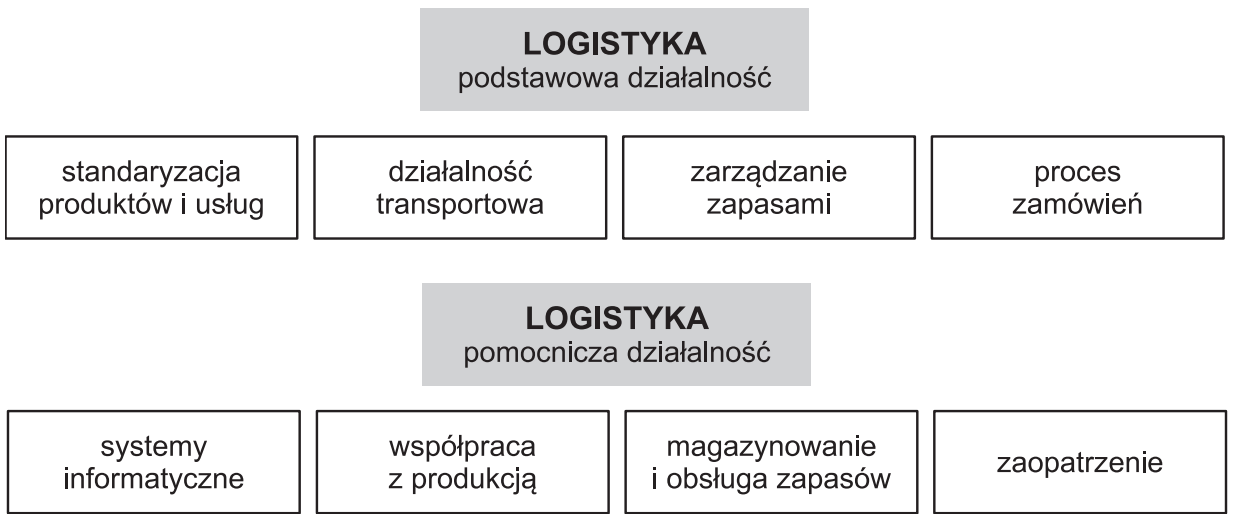

Rysunek 3. Podstawowa i pomocnicza działalność logistyki

Źródło: opracowanie własne na podstawie E. Gołembska, Kompendium wiedzy o logistyce, Wydawnictwo Naukowe PWN, Warszawa 2007, s. 22.

Poprzez właściwie zaplanowane, wdrażane i kontrolowane działania logistyczne w ramach łańcucha dostaw, postrzeganego jako określona sekwencja działań, czyli proces lub procesy skupiające się na finalnym odbiorcy, prowadzone zgodnie ze strategią konkurencyjności na rynku, a związane z efektywnym oraz dynamicznym zarządzaniem przepływami fizycznymi, finansowymi, informacyjnymi, a także wiedzą, które towarzyszą ruchowi produktów i realizacji usług w różnych fazach cyklu ich życia ${ }^{19}$, organizacje mają „fizyczną” możliwość zapewnienia kompleksowej obsługi klientów wewnętrznych (pracowników) i zewnętrznych (konsumentów rynku), dostarczając im właściwych produktów i/lub usług, właściwej jakości, ilości, we właściwym miejscu, czasie, właściwemu klientowi i po właściwej cenie zgodnie z zasadą 7W. Odbywa się to własnymi siłami i środkami lub poprzez dostępne opcje rynkowe, takie jak outsourcing logistyczny polegający na odpłatnym zlecaniu ściśle wyznaczonych usług i procesów do realizacji przez wyspecjalizowane do tego podmioty zewnętrzne (firmy) posiadające odpowiednie zaplecze (np. w zakresie transportu) w zakontraktowanych ramach czasowych.

\subsection{Zdefiniowanie pojęcia bezpieczeńst wa}

Funkcjonując w określonej przestrzeni publicznej i prywatnej, każda jednostka społeczna, grupa czy organizacja ma naturalną potrzebę zapewnienia sobie odpowiednich, czyli dostosowanych do potrzeb i możliwości warunków bezpieczeństwa niezbędnych do bieżącej egzystencji i okoliczności z tym związanych. W interpretacji słownika terminów z zakresu bezpieczeństwa narodowego opracowanego przez Wydział Strategiczno-Obronny Akademii Obrony Narodowej (AON): „Bezpieczeństwo (ang. security) - stan, który daje poczucie pewności i gwarancje jego zachowania oraz szansę na doskonalenie. Jedna

${ }_{19}$ Logistyka.net.pl, Lańcuch dostaw - zagadnienia wybrane, https://www.logistyka.net.pl/bank-wiedzy/ logistyka/item/5040-lancuch-dostaw-zagadnienia-wybrane [dostęp: 16.06.2018]. 
z podstawowych potrzeb człowieka. Jest to sytuacja odznaczająca się brakiem ryzyka utraty czegoś, co człowiek szczególnie ceni, na przykład: zdrowia, pracy, szacunku, uczuć, dóbr materialnych"20. Wyróżniamy między innymi bezpieczeństwo globalne, regionalne, narodowe, militarne, ekonomiczne, polityczne, publiczne, wewnętrzne, społeczne, fizyczne, psychiczne, socjalne, strukturalne oraz personalne ${ }^{21}$. Etymologiczny rodowód pojęcia bezpieczeństwa pochodzi od łacińskiego sine cura (securitas). Pojęcie przetrwało w kilku europejskich językach: ang. security, fr. securité. Definicje wykorzystywane w naukach wojskowych, jak również w naukach o stosunkach międzynarodowych zawierają następujące elementy: stan pewności, spokoju, zabezpieczenia, a więc braku zagrożenia i ochrony przed niebezpieczeństwami, zaspokojenie takich potrzeb, jak: istnienie, przetrwanie, całość, tożsamość, niezależność, spokój, posiadanie, pewność rozwoju, wartość współtworząca inne potrzebne człowiekowi wartości, określony cel, podstawowa potrzeba państw i systemów międzynarodowych; brak bezpieczeństwa oznacza niepokój oraz poczucie zagrożenia ${ }^{22}$. W opinii autorów niniejszego słownika z klasycznych funkcji państwa wynikają dwa aspekty bezpieczeństwa, będące jednocześnie niezbędnymi składnikami pełnego bezpieczeństwa każdego podmiotu, tj. bezpieczeństwo wewnętrzne, oznaczające stabilność oraz harmonię danego państwa lub podmiotu zbiorowego (państw, organizacji, korporacji), a także bezpieczeństwo zewnętrzne, a więc brak zagrożenia ze strony innych podmiotów stosunków międzynarodowych ${ }^{23}$. Bezpieczeństwo powinno się rozumieć głównie dynamicznie (a nie statycznie) jako proces społeczny, w którym podmioty międzynarodowe dążą do eliminacji zagrożenia i podnoszenia swojego stanu pewności ${ }^{24}$. „Bezpieczeństwo absolutne jest wartością nieosiągalną, ma ono bowiem zawsze charakter względny"25. Termin bezpieczeństwo możemy przyporządkować wielu dziedzinom życia, w zależności od uwarunkowań i potrzeb społecznych, uwarunkowań politycznych, sytuacji gospodarczej, sytuacji militarnej i innych.

${ }^{20}$ J. Kaczmarek, W. Łepkowski, B. Zdrodowski (red. nauk.), Stownik terminów z zakresu bezpieczeństwa narodowego, Wydział Strategiczno-Obronny AON, Warszawa 2008, http://mkuliczkowski.pl/static/pdf/slownik. pdf [dostęp: 16.06.2018], s. 14.

${ }_{21}^{2}$ Tamże.

${ }^{22}$ Tamże.

${ }^{23}$ Tamże.

${ }^{24}$ Tamże.

${ }^{25}$ Tamże. 


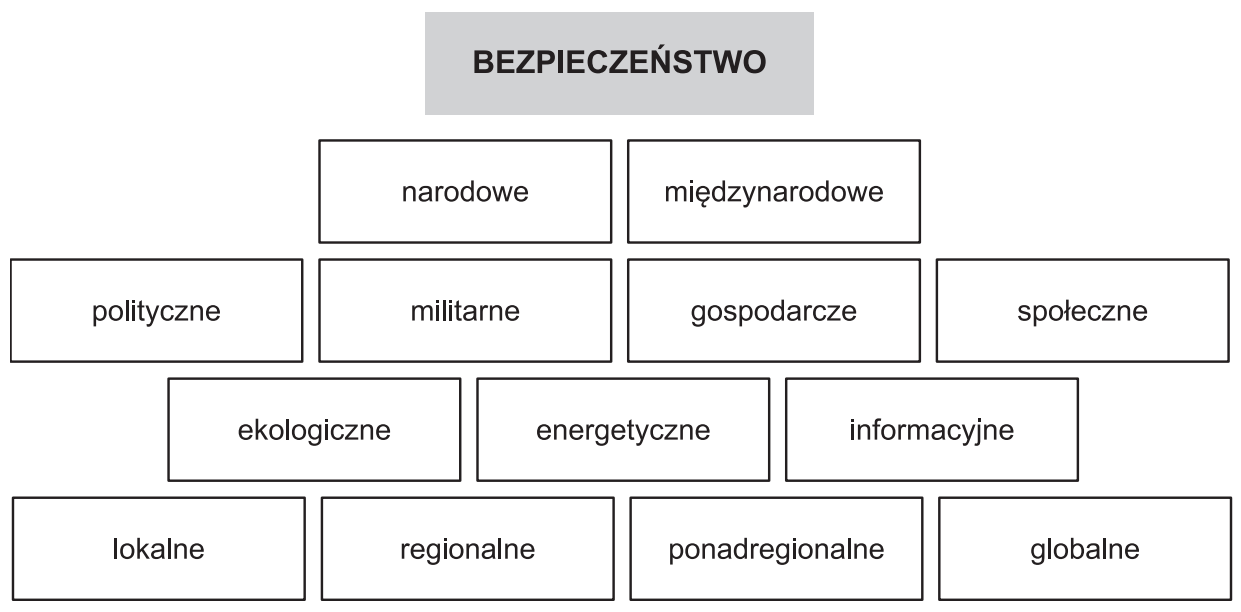

Rysunek 4. Wybrane rodzaje bezpieczeństwa

Źródło: opracowanie własne.

Wśród występujących zagrożeń dla bezpieczeństwa są: zagrożenia wojskowe (zagrożenia dla przetrwania państwa), czyli nadmierne zbrojenia, brak równowagi wojskowej między państwami, brak demokratycznej kontroli nad armią, zagrożenia polityczne (niedostateczna współpraca, brak zaufania i postawa konfrontacyjna, próby rozwiązywania konfliktów międzynarodowych siłą), ponadto zagrożenia mogące zakłócić dobrobyt (zagrożenia ekonomiczne), trwały rozwój (zagrożenia ekologiczne), tożsamość (zagrożenia społeczno-kulturowe) ${ }^{26}$.

„Bezpieczeństwo może być rozumiane negatywnie bądź pozytywnie. W rozumieniu negatywnym zwraca się przede wszystkim uwagę na brak zagrożeń, w pozytywnym zaś traktuje się je jako stan pewności, przetrwania, swobód rozwojowych"27. Bezpieczeństwo dzielimy według kryteriów: podmiotowego (bezpieczeństwo narodowe oraz bezpieczeństwo międzynarodowe), przedmiotowego (bezpieczeństwo polityczne, wojskowe, gospodarcze, społeczne, kulturowe, ideologiczne, ekologiczne, informacyjne), przestrzennego (bezpieczeństwo lokalne, subregionalne, regionalne, ponadregionalne i globalne), czasu (stan bezpieczeństwa i proces bezpieczeństwa) oraz sposobu organizowania (indywidualne, unilaterialne) - hegemonizm mocarstwowy, izolacjonizm, neutralność, niezaangażowanie, sojusze (system blokowy), system bezpieczeństwa kooperacyjnego, system bezpieczeństwa zbiorowego ${ }^{28}$.

„Stan bezpieczeństwa nie jest stabilny - nie jest dobrem danym systemowi gospodarczemu raz na zawsze. W świecie realnym występują ciągłe jego zagrożenia, zarówno od sił natury, jak i niezamierzonych oraz zamierzonych efektów działalności człowieka. Każdy podmiot musi zatem czynić starania o zapewnienie sobie stabilności stanu bezpieczeństwa. Każdy system gospodarczy jako jeden z podmiotów społecznych winien wykształcić

\footnotetext{
26 Tamże.

27 Tamże.

28 Tamże, s. 15.
} 
w swej działalności możliwość szybkiego reagowania na wszelkie zmiany w otoczeniu wewnętrznym i zewnętrznym, w tym również możliwość współpracy w ramach systemu bezpieczeństwa społeczności lokalnych"29.

Systemy bezpieczeństwa wdrażane przez instytucje pożytku publicznego i firmy komercyjne są zazwyczaj oparte na przeprowadzonych wcześniej analizach potencjalnych zagrożeń mogących doprowadzić do sytuacji kryzysowych. „System bezpieczeństwa danego podmiotu powinien być dostosowany do jego potencjalnych zagrożeń oraz pożądanego poziomu bezpieczeństwa, jaki musi być mu zapewniony"30. Zdaniem A. Szymonika ilość oraz jakość środków ratownictwa koniecznych do zapewnienia danemu podmiotowi pożądanego poziomu bezpieczeństwa, ich organizacja, jak również sposób prowadzenia działań (procesów) ratowniczych po wyzwoleniu zagrożenia (zajścia zdarzenia) zależą od jego rodzaju, skali oraz prognozy możliwości wystąpienia także zagrożeń innych rodzajów ${ }^{31}$. Dążenie do zapewnienia bezpieczeństwa w różnych sektorach gospodarki i na różnym poziomie funkcjonalnym wymaga od organizacji publicznych i prywatnych wzmożonego wysiłku w celu wczesnej identyfikacji zagrożeń, wdrożenia adekwatnych do sytuacji środków zapobiegawczych, a także umożliwienia bieżącego realizowania założonych celów. Procesy globalizacyjne pociągają za sobą coraz to „nowe”, bardziej wyrafinowane formy zagrożeń na przykład w obszarze cybernetyki, informatyki, logistyki, dlatego też budżety odpowiedzialnych państw i funkcjonujących w nich podmiotów powinny uwzględniać i wydzielać odpowiednie zasoby na ich zwalczanie oraz szeroko pojęte zabezpieczenie w celu utrzymania stabilności procesów na poziomie strategicznym, taktycznym i operacyjnym.

\section{Logistyka w sytuacjach kryzysowych}

\subsection{Podstawowe zadania logistyki w sytuacjach kryzysowych}

Logistyka sytuacji kryzysowych różni się od logistyki wojskowej oraz logistyki cywilnej głównie: podmiotem obstugi, którym jest ludność poszkodowana w sytuacjach kryzysowych, w przypadku logistyki wojskowej podmiotem są wojska (szkolące się, walczące), a w przypadku logistyki cywilnej - klienci funkcjonujący na konkurencyjnym rynku; następnie środowiskiem funkcjonowania, do którego zaliczamy rejony reagowania kryzysowego, w logistyce wojskowej środowiskiem tym jest pole walki, a w logistyce cywilnej - wolny rynek, który kształtuje popyt oraz ceny; głównym celem funkcjonowania, jakim jest zapewnienie warunków do przetrwania wszystkim poszkodowanym, w logistyce wojskowej jest to zagwarantowanie wysokiej skuteczności zabezpieczenia logistycznego wojsk, a w logistyce cywilnej - maksymalizacja zysków przedsiębiorstwa ${ }^{32}$.

Sytuacja kryzysowa to sytuacja, która jest następstwem zagrożenia, prowadząca w rezultacie do zerwania lub znacznego naruszenia więzów społecznych przy równoczesnym

\footnotetext{
29 A. Szymonik, Logistyka w bezpieczeństwie, Wydawnictwo Difin, Warszawa 2011, s. 22-23.

30 Tamże, s. 23.

31 Tamże.

32 E. Nowak, Logistyka w sytuacjach kryzysowych, AON, Warszawa 2009, s. 18.
} 
poważnym zakłóceniu w funkcjonowaniu instytucji publicznych, lecz w takim stopniu, że użyte środki niezbędne do zapewnienia lub przywrócenia bezpieczeństwa nie uzasadniają wprowadzenia żadnego ze stanów nadzwyczajnych, o których jest mowa w art. 228 ust. 1 Konstytucji Rzeczypospolitej Polskiej ${ }^{33}$. Zadania logistyczne wykonywane w ramach sytuacji kryzysowych obejmują przede wszystkim przedsięwzięcia dotyczące określonych grup zagrożeń. Do pierwszej grupy zaliczamy zadania związane z likwidacją nadzwyczajnych zagrożeń środowiska, czyli klęski żywiołowe, zdarzenia wywołane przyczynami cywilizacyjnymi, takimi jak: katastrofy, awarie i inne zdarzenia spowodowane działaniem lub zaniedbaniem człowieka. Do grupy pierwszej zagrożeń należą między innymi: pożary, powodzie, zatopienia, epidemie chorób ludzi, epidemie chorób roślin, epidemie chorób zwierząt, skażenia promieniotwórcze i chemiczne, katastrofy górnicze, katastrofy budowlane, katastrofy komunikacyjne, awarie sieci energetycznych. Do drugiej grupy zaliczamy zadania związane z likwidacją zagrożeń właściwych dla ochrony wewnętrznego bezpieczeństwa, porządku publicznego oraz ochrony granic. Do grupy drugiej zagrożeń należą między innymi: zdarzenia godzące w porządek konstytucyjny państwa, terroryzm, blokady dróg, nielegalne demonstracje, konflikty na tle etnicznym, masowa migracja. Do trzeciej grupy zaliczamy zadania związane z likwidacją skutków cyberterroryzmu rozumianego jako działanie mające na celu niszczenie lub zniekształcenie informacji przesyłanej, przetwarzanej, przechowywanej w systemach informatycznych. Do czwartej grupy zaliczamy zadania związane z likwidacją skutków kryzysu finansowego dotykającego wszystkich, w tym inwestorów indywidualnych lub przedsiębiorstwa ${ }^{34}$. Wyłącznie analiza systemowa oraz zarządzanie ryzykiem może według A. Szymonika złagodzić niechciane sytuacje kryzysów finansowych, których istnienie w świecie biznesu jest nie do podważenia ${ }^{35}$.

„Logistyka w sytuacjach kryzysowych to dyscyplina naukowa, która tworzy całokształt systemowych rozwiązań niezbędnych do pełnego i racjonalnego zaspokajania potrzeb organom wykonawczym oraz zarządzającym bezpieczeństwem, uwzględniając możliwości ekonomiczne państwa w zakresie koniecznym do szkolenia, osiągania i utrzymywania zdolności oraz gotowości bojowej na poziomie wymaganym do zapewnienia pożądanego bezpieczeństwa dla określonego podmiotu"36.

\subsection{Ogólna charakterystyka zarządzania logistyką w sytuacjach kryzysowych}

Zarządzanie organizacją i jej zasobami w sytuacji kryzysowej, czyli planowanie, organizowanie, przewodzenie i kontrolowanie działań w nadzwyczajnych, ponadstandardowych warunkach, nacechowanych dynamizmem i zmiennością zdarzeń, wymaga

33 W. Otwinowski, Kryzys i sytuacja kryzysowa, „Przegląd Naukowo-Metodyczny. Edukacja dla Bezpieczeństwa” 2010, nr 2, s. 88, [za:] Encyklopedia Zarządzania, Sytuacja kryzysowa, https://mfiles.pl/pl/ index.php/Sytuacja kryzysowa [dostęp: 16.06.2018].

34 A. Szymonik, Logistyka w bezpieczeństwie..., dz. cyt., s. 47.

35 Tamże.

36 Tamże, s. 48. 
od kierownictwa zabezpieczenia kluczowych z punktu widzenia egzystencji organizacji obszarów i realizowanych w nich procesów. Należy bowiem mieć świadomość, że pomimo wystąpienia sytuacji kryzysowej w określonym obszarze organizacji musi ona bieżąco realizować zobowiązania względem świadczeniobiorców jej usług, co dotyczy zwłaszcza organizacji o strategicznym znaczeniu dla bezpieczeństwa obywateli, między innymi szpitali, służb mundurowych, jednostek samorządu terytorialnego, ale również podmiotów produkcyjnych, na przykład z branży spożywczej, farmaceutycznej, czy usługowych, na przykład z branży przewozowej, informatycznej. Zarządzanie logistyką w sytuacjach kryzysowych musi uwzględniać następujące elementy: ratowanie zdrowia i życia poszkodowanych, presję czasu, niekompletne dane do podjęcia decyzji (zakłócenia w systemach łączności i przekazywaniu informacji), nieprzewidywalne zdarzenia, zaangażowanie środków masowego przekazu, negatywny stosunek opinii publicznej, zewnętrzną interwencję w tok zdarzeń oraz działań, nieplanowane zadania wynikające z ustaw o stanie wyjątkowym, o stanie klęski żywiołowej, o stanie wojny, a także ograniczone siły i środki ${ }^{37}$. Do obszarów łańcucha logistycznego w zarządzaniu logistyką w sytuacjach kryzysowych zaliczamy między innymi fizyczny przepływ ludzi i dóbr rzeczowych, procesy informacyjno-decyzyjne, a także utrzymanie zapasów i związane z nimi koszty logistyczne.

\section{ZARZADDZANIE LOGISTYKA}

W SYTUACJACH KRYZYSOWYCH

łańcuch logistyczny

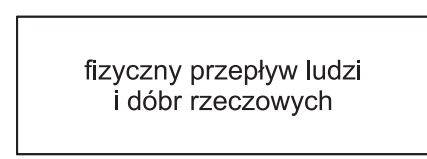

procesy informacyjno-decyzyjne na poziomie strategicznym, taktycznym, operacyjnym
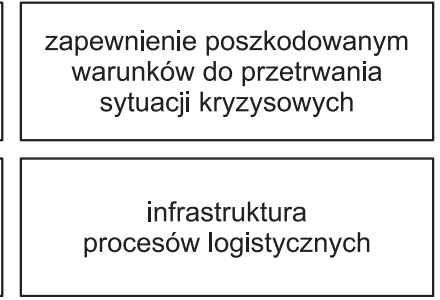

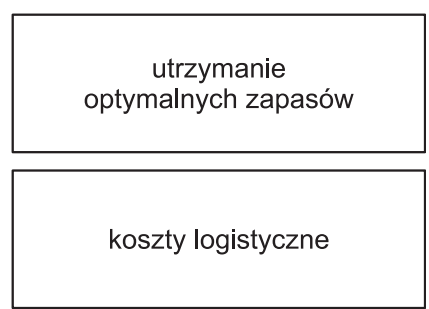

Rysunek 5. Wybrane obszary łańcucha logistycznego w zarządzaniu logistyką w sytuacjach kryzysowych

Źródło: opracowanie własne na podstawie A. Szymonik, Logistyka w bezpieczeństwie, Wydawnictwo Difin, Warszawa 2011.

Zarządzanie logistyką w sytuacjach kryzysowych obejmuje następujące obszary łańcucha logistycznego: fizyczny przepływ ludzi i dóbr rzeczowych, zapewnienie osobom poszkodowanym warunków do przetrwania sytuacji kryzysowych, utrzymanie optymalnych zapasów, procesy informacyjno-decyzyjne na poziomie taktycznym, operacyjnym, strategicznym, infrastrukturę procesów logistycznych, koszty logistyczne ${ }^{38}$. Wszystkie z wymienionych obszarów łańcucha logistycznego będą różnie reagować, co jest uzależnione od typu,

\footnotetext{
37 Tamże.

38 Tamże.
} 
rodzaju, czasu trwania, zasięgu, częstotliwości sytuacji kryzysowych ${ }^{39}$. Sformułowana na wstępie hipoteza badawcza, w której założono, że logistyka pozytywnie wpływa na efektywność podejmowania decyzji w warunkach kryzysowych, została potwierdzona na podstawie przeprowadzonego studium literatury oraz przedstawienia praktycznych przykładów celowości zastosowania działań logistycznych w warunkach zagrożenia. Zarządzanie kryzysowe stanowi najistotniejszy element systemu bezpieczeństwa państwa, decydując o jego zdolności lub jej braku do sprostania wyzwaniom, przeciwstawiania się zagrożeniom, wykorzystywania szans, które są pochodnymi tych pierwszych ${ }^{40}$.

„Zarządzanie kryzysowe jest jednym z elementów szeroko pojętego zarządzania. Dotyczy działań mających na celu ograniczenie wystąpienia zagrożenia, a w razie jego powstania szybkiej likwidacji, a następnie minimalizacji i usuwania powstałych strat. Zarządzanie kryzysowe obejmuje nie tylko działania realizowane podczas trwania kryzysu, ale także wiele przedsięwzięć podejmowanych przed jego ewentualnym zaistnieniem"41. Włączenie procesów logistycznych jest niezbędne zarówno w sytuacjach kryzysowych, jak i w zarządzaniu kryzysowym, bowiem zapewniają one przepływ zasobów i informacji pomiędzy strefą zagrożenia a ośrodkiem decyzyjnym oraz przesądzają o skuteczności użytych sił i środków. Logistyka bezpieczeństwa jest bez wątpienia praktycznym instrumentem mającym zastosowanie do różnego rodzaju zagrożeń występujących wraz z postępem cywilizacyjnym i działalnością człowieka.

\section{Bibliografia}

Abt S., Woźniak H., Podstawy logistyki, Uniwersytet Gdański, Gdańsk 1993.

Ficoń K., Procesy logistyczne w przedsiębiorstwie, Impuls Plus Consulting, Gdynia 2001.

Gołembska E., Istota logistyki, podstawowe pojęcia, [w:] E. Gołembska (red.), Kompendium wiedzy o logistyce, Wydawnictwo Naukowe PWN, Warszawa 2007.

Kitler W., Zarządzanie kryzysowe jako element zarzadzania bezpieczeństwem narodowym, [w:] J. Gryz, W. Kitler (red.), System reagowania kryzysowego, Wydawnictwo Adam Marszałek, Toruń 2007.

Lambert D.M., Stock J.R., Strategic Logistics Management, R.D. Irwin, Inc. Homewood, Illinois 1993.

Nowak E., Logistyka w sytuacjach kryzysowych, AON, Warszawa 2009.

Otwinowski W., Kryzys i sytuacja kryzysowa, „Przegląd Naukowo-Metodyczny. Edukacja dla Bezpieczeństwa” 2010, nr 2.

Rogozińska-Mitrut J., Podstawy zarządzania kryzysowego, Oficyna Wydawnicza Aspra-Jr, Warszawa 2010.

39 Tamże.

40 W. Kitler, Zarzadzanie kryzysowe jako element zarządzania bezpieczeństwem narodowym, [w:] J. Gryz, W. Kitler (red.), System reagowania kryzysowego, Wydawnictwo Adam Marszałek, Toruń 2007, s. 42.

41 J. Rogozińska-Mitrut, Podstawy zarządzania kryzysowego, Oficyna Wydawnicza Aspra-Jr, Warszawa 2010, s. 49. 
Szymonik A., Logistyka i zarządzanie łańcuchem dostaw, cz. 1, Wydawnictwo Difin, Warszawa 2010.

Szymonik A., Logistyka w bezpieczeństwie, Wydawnictwo Difin, Warszawa 2011.

\section{Strony internetowe}

Encyklopedia Zarządzania, Analiza systemowa, https://mfiles.pl/pl/index.php/Analiza_systemowa [dostęp: 6.10.2018].

Encyklopedia Zarządzania, Sytuacja kryzysowa, https://mfiles.pl/pl/index.php/Sytuacja_kryzysowa [dostęp: 16.06.2018].

Governica, Encyklopedia, https://www.governica.com/Logistyka [dostęp: 16.06.2018].

Kaczmarek J., Łepkowski W., Zdrodowski B. (red. nauk.), Słownik terminów z zakresu bezpieczeństwa narodowego, Wydział Strategiczno-Obronny AON, Warszawa 2008, http:// mkuliczkowski.pl/static/pdf/slownik.pdf [dostęp: 16.06.2018].

Logistyka.net.pl, Łańcuch dostaw - zagadnienia wybrane, https://www.logistyka.net.pl/bank-wiedzy/logistyka/item/5040-lancuch-dostaw-zagadnienia-wybrane [dostęp: 16.06.2018].

Logistyka.net.pl, Stownik logistyczny, https://www.logistyka.net.pl/slownik/main?star$\mathrm{t}=0 \&$ keyword=logistyka [dostęp: 16.06.2018].

\section{Streszczenie}

\section{Znaczenie logistyki w zarządzaniu kryzysowym}

W opracowaniu zdefiniowano pojęcie logistyki i jej istotę, zobrazowano kluczową i pomocniczą działalność logistyczną, omówiono pojęcie bezpieczeństwa i jego rodzaje, a także pojęcie sytuacji kryzysowej, opisano zadania logistyczne realizowane w ramach sytuacji kryzysowych, wyjaśniono pojęcie logistyki w sytuacjach kryzysowych oraz przedstawiono ogólnie zarządzanie logistyką w sytuacjach kryzysowych.

Słowa kluczowe: logistyka, bezpieczeństwo, sytuacja kryzysowa

\section{Summary}

\section{The meaning of logistics in crisis management}

This article provides a definition for the term logistics. It describes key and support logistic activities. It defines the term safety and its various types. It provides a definition of a crisis situation and describes logistic tasks in crisis situations. It also defines the term logistics in crisis situations and presents logistic management in crisis situations in a general way. Keywords: logistics, safety, crisis situation, logistics in crisis situations, logistics management in crisis situations 


\section{Society in the theory of Karl Popper}

The aim of this article is to analyse the dichotomy between an open and a closed society and to examine the problem of individual freedom and the freedom of society as the foundations of a civil society ${ }^{1}$. The author puts forward the hypothesis that the foundations of every contemporary civil society is the open society as discussed by Karl Popper.

What is the threat of a closed society to a civil society? In what circumstances can a civil society develop? When can one talk about individual freedom? When can we talk about the freedom of the whole society?

For over two thousand years people have striven to liberate themselves of prejudice and the influence of authorities. They have sought to construct a civil society that would correspond to the standards of freedom of the mind and humanity. They want to take responsibility for the world. The moral longings for a betterment of one's own and fellow-man's fate are civil problems of our era. Humanity still endures the process of transformation from tribal to open society.

Popper's philosophy ${ }^{2}$ is soaked through with faith in the human mind and love of free$\mathrm{dom}^{3}$, defined as the right of an individual to make independent decisions and confront the consequences of those decisions. In his book The Open Society and Its Enemies Popper refers to social philosophy in an unflattering manner as that which claims the discovery of historical laws and which allows for the prediction of historical events. He ironically

\footnotetext{
${ }^{1}$ Civil society understanding as civic (rule of law, liberal democratic).

${ }^{2}$ Cf.: A. Chmielewski, Filozofia Poppera: analiza krytyczna, Wydawnictwo Uniwersytetu Wrocławskiego, Wrocław 1995; K. Niebrój, R. Karla, Poppera koncepcja prawdy: kwestia podstawowego nośnika prawdziwości, Wydawnictwo Uniwersytetu Śląskiego, Katowice 2010; K. Popper, Społeczeństwo otwarte i jego wrogowie, PWN, Warszawa 2010; E. Pietruska-Madey, Wiedza i czlowiek: szkice o filozofii Karla Poppera, Wydział Filozofii i Socjologii Uniwersytetu Warszawskiego, Warszawa 1997; G. Soros, Kryzys światowego kapitalizmu: zagrożenie dla społeczeństwa otwartego, Muza, Warszawa 1999; J. Szacki, Historia myśli socjologicznej, PWN, Warszawa 2011.

${ }^{3}$ Cf.; "faith in reason, freedom and the brotherhood of all men - the new faith, and as I believe, the only possible faith, of the open society". K. Popper, op. cit., p. 2, 265.
} 
called this philosophy "allegedly scientific prophecies" and recognized it as a form of escapism from reality and present responsibilities, an escape into an unknown paradise. He therefore departed from the paradigm of history. To the question 'Does history make any sense?', he responds: certainly not. For Popper, history does not have any aim and does not represent any values.

Popper criticises Plato, whose theory he understood as an escape into future paradise a Platonian vision of state that he interpreted as an attack on freedom and reason, leaning towards a closed, totalitarian structure of social life, which reduces people to obedient thoughtless puppets of authority. He criticizes Hegel's and Marx's concepts, comparing both thinkers to arrogant intellectual prophets and fathers of the modern totalitarian system. He wanted to propose an alternative to an authoritarian society. Popper believed in a civil society based on piecemeal social engineering relying on solving immediate conflicts instead of following a general idea of a social well-being. People trapped under despotic rule are intimidated and deprived of the right to take responsibility for own actions and are therefore stripped of their humanity.

A part of being human, according to Popper, is having a moral responsibility that can only evolve under conditions of political freedom that is solely secured by democracy; "what Marxists describe disparagingly as 'mere formal freedom' becomes the basis of everything else. This 'mere formal freedom', i.e. democracy, the right of the people to judge and to dismiss their government, is the only known device by which we can try to protect ourselves against the misuse of political power; it is the control of the rulers by the ruled. And since political power can control economic power, political democracy is also the only means for the control of economic power by the ruled. Without democratic control, there can be no earthly reason why any government should not use its political and economic power for purposes very different from the protection of the freedom of its

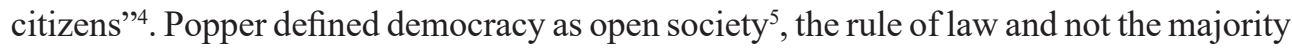
rule. He was perfectly aware that government by the people can result in tyranny by the majority, which is not any better than any other form of tyranny. The political purpose of democracy is to provide freedom and justice reaching out as far as possible without any undue limitations to freedom ${ }^{6}$. Popper sees democracy as a guardian of law and freedom, a guardian of possessions. He doesn't approve of Marx's claim that economic power lies at the root of all evil, agreeing more with the views of Walter Lippmann and Bertrand

4 Ibidem, p. 2, 177.

5 It is worth noting the fact that terms the open/closed society were coined and first introduced into philosophy by Henri Bergson - Popper does not hesitate to mention this. Popper notes that his understanding of those terms slightly differs from that of Bergson's. Freedom according to Bergson is closely associated with the creative aspect of an individual whereas for Popper it is linked with liberalism. More on Bergson's open society can be found in: M. Środa, Ludzie i terminy, „Wiedza i Życie”, June 1996.

${ }^{6}$ Popper writes in a preface addressing the Polish audience: "The great thinkers of the past who obliged us with these ideas, defended freedom in the name of a truth they were fully aware of: I can rule on my own! Our ideal therefore is not a majority rule nor "complete freedom" but autonomy. The law needs to reach where autonomy failed to extend or was not introduced. According to Kant's teachings life in a society cannot be completely free: the freedom of every individual needs to be limited in a way as not to interfere with the freedoms of others. [...] If that rule is not abided by, law supported by the power of the government is obliged to interfere. That in short is the idea of a free and open society" - K. Popper, op. cit., p. 1, 8. 
Russel17 that "it is only the active intervention of the state - the protection of property by laws backed by physical sanctions - which makes of wealth a potential source of power; for without this intervention a man would soon be without his wealth. Economic power is therefore entirely dependent on political and physical power"8. Wiktor Osiatyński points out that Popper strongly supports individualism in opposition to collectivism and tribalism ${ }^{9}$.

The idea of an open society can be fully understood through a comparison with a closed society. What in essence is a closed society? Popper highlights the magicality and irrationality of such societies, the leaning towards a tribal structure of social life: "It is one of the characteristics of the magical attitude of a primitive tribal or a 'closed' society that it lives in a charmed circle of unchanging taboos, of laws and customs which are felt to be as inevitable as the rising of the sun or the cycle of the seasons, or similar obvious regularities of nature" 10 . It is, therefore, a magical, collective, tribal society - it can be described in terms of a biological or an organic theory of the state. Popper compares it to a living organism: "A closed society resembles a herd or a tribe in being a semi-organic unit whose members are held together by semi-biological ties - kinship, living together, sharing common efforts, common dangers, common joys and common distress" "11. Below is a list of "spiritual treasures" of a closed (totalitarian) ${ }^{12}$ society, which Popper ironically concocted in response to his reading of Hegel and Marx.

The first feature of closed society is obedience ${ }^{13}$ of the citizens to the rulers, following orders, released from liabilities - as Tacqueville would convey it - raising "slaves"

${ }^{7}$ B. Russell, Power: A New Social Analysis, Routledge, New York 1938, p. 123; W. Lippmann, The Good Society, Brown and Co., Boston 1937, p. 188.

${ }^{8}$ K. Popper, op. cit., p. 2, 178.

9 W. Osiatyński, Spoleczeństwo otwarte wedtug Poppera, „Wiedza i Życie”, June 1996.

${ }^{10}$ K. Popper, op. cit., p. 1, 93.

${ }^{11}$ Ibidem, p. 250.

${ }^{12}$ Daniel Grinberg points out how the post-war and modern understanding of the term 'totalitarianism' is close to that of Popper's vision. He states: "The key definition of totalitarianism, specified and codified in the mid ' 50 s by Carl Friedrich and Zbigniew Brzeziński, made an impressive career not only in political science. The following elements were supposed to contribute towards „the totalitarian syndrome”: 1) state ideology - monopolistic and obligatory for all citizens; 2) the mass membership party organised hierarchically, intertwined with the state administration; 3 ) completely compliant with political party and bureaucrats, armed forces together with the rest of the society'; 4) state monopoly of information and media; 5) physical and psychological police terror as one of the core principles of rule; 6) centrally planned economy [...]. Extensive discussions that were carried out with consistant intensity up to the late " $60 \mathrm{~s} \mathrm{did} \mathrm{not} \mathrm{result} \mathrm{in} \mathrm{an} \mathrm{agreement} \mathrm{as}$ to the distribution of posts. They did, however, enable a degree of clarification on the subject of a modified vision of social phenomenon. In this new vision, free from the enstrangling corset of multipoint syndromes, the emphasis is put on the eradication of a civil society actively absorbed by the omnipresent state, on striving for a gigantic mono-party state in order to mobilise mass society and on postulating a "permanent revolution", generated in all state structures through an unbrindled movement of activism... Although until recently the term totalitarianism was perceived literally and associated mostly with something ruthless and inevitable, encompasing and final, nowadays it is taken more figuratively; meaning not as much a factual state but the act of trying to achieve it; describing not an immovable monolith but a gradual and reversible sociopolitical phenomenon". D. Grinberg, Pre-face to Polish edition from 1993, [in:] H. Arendt, Korzenie totalitaryzmu, Wydawnictwa Akademickie i Profesjonalne, Warszawa 2008, p. 747-750.

${ }^{13}$ Bergson perceived intuition as well as reason and the ego as the basis for obedience. Popper, on the other hand, clearly connected obedience with primordiality and mindless abandonment of one's freedoms in favour of the rulers. 
instead of independent citizens that can take responsibility for their own actions. Plato states that: "The greatest principle of all is that nobody, whether male or female, should be without a leader. Nor should the mind of anybody be habituated to letting him do anything at all on his own initiative; neither out of zeal, nor even playfully. But in war and in the midst of peace - to his leader he shall direct his eye and follow him faithfully. And even in the smallest matter he should stand under leadership. For example, he should get up, or move, or wash, or take his meals... only if he has been told to do so. In a word, he should teach his soul, by long habit, never to dream of acting independently, and to become utterly incapable of it" ${ }^{14}$. Hegel echoed Plato, which Popper wrote about as follows: "Just as he [Hegel] opposes liberty and equality, so he opposes the brotherhood of man, humanitarianism, or, as he says, 'philantropy'. Conscience must be replaced by blind obedience and by romantic Heraclitean ethics of fame and fate, and the brotherhood of man by a totalitarian nationalism"15.

Another of the features is of closed society is indoctrination - controlling minds (Orwellian control of thoughts $)^{16}$. The constant and harsh censure of all intellectual activity and perpetual propaganda is directed at unifying and molding of minds ${ }^{17}$. The state is free of any moral obligations. Therefore, history is the only judge. The only rule outlining individual codes of behaviour is the collective good - propaganda lies and adjusting the truth become acceptable. The truth is important as long as it serves the state. If the situation and state interest call for it the rulers can cheat and lie. Since intellectual independency is the foundations of intellectual dexterity, the totalitarian state takes all measures neccessary not to allow for the development of critical thinking of its citizens. Intellectual independence leads to complications, which prove impossible to overcome within the framwork of any form of authoritarianism: "The authoritarian will in general select those who obey, who believe, who respond to his influence. But in doing so, he is bound to select medioctities. For he excludes those who revolt, who doubt, who dare to resist his influence. Never can an authority admit that the intellectually courageous, i.e. those who dare to defy his authority, may be the most valuable type" ${ }^{18}$.

Next feature illustrating the closed society is a stable form of mobilisation and education system directed at the development of physical strength. Training of the body over training of the spirit - sport instead of the humanities - intensive and constant form of mobilisation. Monopoly of the ruling class for military training - the right to carry arms and access education. Popper highlights this aspect of totalitarianism within Plato's works: "The political principle that determines the education of the soul, namely, the preservation of the stability of the state, determines also that of the body. The aim is simply that of

14 K. Popper, op. cit., p. 1, 25.

15 Ibidem, p. 2, 73.

${ }^{16}$ Cf.: "The pessimistic fear that totalitarian regime can cause irreversible changes in minds of its victims or even change the essence of humanity, can be detected in a book Eichmann in Jerusalem from 1963, in which a slighlty metaphysical concept of 'radical evil' was substituted [by Hannah Ardent] with a completely contrary idea of 'banality of evil'. D. Grinberg, op. cit., p. 746.

17 K. Popper, op. cit., p. 1, 133.

18 Ibidem, p. 1, 198. 
Sparta. While the Athenian citizen was educated to a general versatility, Plato demands that the ruling class shall be trained as a class of professional warriors, ready to strike against enemies from without or from within the state" 19.

Popper also adds to the list strict isolation of the ruling class: the superiority of the ruling race over the ruled, who serve as the working class, fulfilling the needs of those ruling. "Plato distinguishes three classes in his best state, the guardians, their armed auxiliaries or warriors, and the working class. But actually there are only two castes, the military caste - the armed and educated rulers - and unarmed and uneducated ruled, the human sheep; for the guardians are no separate caste, but merely old and wise warriors who have been promoted from the ranks of the auxiliaries. That Plato divides his ruling caste into two classes, the guardians and the auxiliaries, without elaborating similar subdivision within the working class, is largely due to the fact that he is interested only in the rulers" 20 . The caste system was connected with racial purity, mixing race, according to Plato, led to the degradation of state. Therefore, class intermingling was considered a great crime ${ }^{21}$.

There is another feature on Popper's list, namely strong interference of state into private matters of citizens - communistic principle (uniformism). For Plato, state interference meant introducing a completely new social structure, dependent on a group, with the removal of the family unit. Plato stated: "No member of the ruling class must be able to identify his children, or his parents. The family must be destroyed, or rather, extended to cover the whole warrior class. Family loyalties might otherwise become a possible source of disunion; therefore "each should look upon all as if belonging to one family" ${ }^{22}$. Communism in which there is no place for major poverty as well as excessive wealth, was supposed to protect people from the perils of an economic nature and serve as means of reducing the economic interests and guarantee ruling class unity.

Popper also draws attention tostate autarchy. State interest takes precedent - the state needs to strive for economic autarchy otherwise its stability will be shaken. That which serves the greatness of the state, caste or part becomes law. Even such a value as justice sustains the power, health and stability of a state: "Plato's theory of justice, as presented in the Republic and later works, is a conscious attempt to get the better of the egalitarian, individualistic, and protectionist tendencies of his time, and to re-establish the claims of tribalism by developing a totalitarian moral theory"23.

According to Popper, closed society is also characterized by nationalism, which is as a historicist mode of thinking that defines the state as an embodiment of a God/Spirit of a self-forming nation (or race). One chosen nation (chosen race) is destined to dominate the world. Popper highlights that modern nationalism can be based on language, as is the case with Ficht, or on a theory of the historical nation as is the case with Hegel. The nation, according to Hegel, is a unified spirit that operates through history. It is unified by a common enemy and the brotherhood of arms during a conflict. Popper warns that nationalism

\footnotetext{
19 Ibidem, p. $1,89$.

${ }^{20}$ Ibidem, p. 1, 79.

${ }^{21}$ Ibidem, p. 1, 82.

${ }^{22}$ Cf.: K. Popper, op. cit., p. 1, 81.

23 Ibidem, p. 1, 177.
} 
appeals to our primal tribal instincts, to feelings and prejudice and to a nostalgic craving for setting oneself free of the individual responsibility in place of a group or collective liablility: "The principle of the national state, that is to say, the political demand that the territory of every state should coincide with the territory inhabited by one nation, is by no means so self-evident as it seems to appear to many people to-day. Even if anyone knew what he meant when he spoke of nationality, it would be not at all clear why nationality should be accepted as a fundamental political category, more important for instance than religion, or birth within a certain geographical region, or loyalty to a dynasty, or a political creed like democracy (which forms, one might say, the uniting factor of multi-lingual Switzerland). [...] The principle of the national state is not only inapplicable but it has never been clearly conceived. It is a myth. It is an irrational, a romantic and Utopian dream, a dream of naturalism and of tribal collectivism"24.

We will meet in a closed society an ethical idea of war, glorification of war. The state as the natural enemy of all other states must assert its existance in war. The 'ethical' idea of war (total and collectivist) especially in the case of a young state against an old one. War fate and fame are the most desired goods.

We meet also a significant role of an individual. The creative role of the Great Man, the world-historical personality, the man of deep knowledge and great passion (now, the principle of leadership). The ideal of a heroic life (live dangerously) and "the 'heroic man' as opposed to the petty bourgeoisie and his life of shallow mediocrity" 25 . Popper defied the closed societies (totalitarian) with the idea of an open society that guarantees individual freedom, especially the freedom of thought, that enables piecemeal social engineering, understood as a gradual improvement of structures and institutions of social life: "the closed society is characterized by the belief in magical taboos, while the open society is one which men have learned to be to some extent critical of taboos, and to base decisions on the authority of their own intelligence (after discusssion)"26. The transition process from tribal to open society is far from completed, our civilisation, as Popper states, has not yet fully recovered from the shock of its birth - the transition from the tribal ot 'closed society', with its submission to magical forces, to the 'open society' which sets free the critical powers of man.

What steps should be taken in order to build open society? Popper does not provide a direct answer to this question. However, a careful study of his works makes it possible to devise a map leading to an open society. Most of all he notes that there is no return to a harmonious state of nature. The process of the civilizational development was established. If we turn back, then we must go back the whole way - we must return to the beasts. The only direction we can take on a road to development is that towards an open society, following reason and freedom. Any attempt at violating these values through the persecution of reason and truth means a devastation of what is human: "But if we wish to remain human, then there is only one way, the way into the open society. We must go into

\footnotetext{
24 Ibidem, p. 2, 75.

25 Ibidem, p. 2, 90-91.

26 Ibidem, p. 1, 288.
} 
the unknown, the uncertain and insecure, using what reason we may have to plan as well as we can for both security and freedom"27. The first and the most important indication the author of The Open Society and Its Enemies gives us is the freedom of an individual fearing responsibility. Popper warns against escaping reality, the here and now, in exchange for building future paradise. He claims: "the only rational attitude and the only Christian attitude towards the history of freedom is the belief that we are the ones responsible for it just as we are responsible for our actions during our lifetime and that our only judge can be our coinscience and not material success"28:

People should not pose as prophets but become the makers of one's own fate. Instead of fortune telling be hard-working and mindful of commiting mistakes. The future depends on ourselves and we do not depend on any historical necessity. Instead of looking for justifications in history we should follow our own coinscience and reason: "it is we, and we alone, who are responsible for adopting or rejecting some suggested moral laws; it is we who must distinguish between the true prophets and the false prophets" 29 .

Popper was fully aware how difficult it is to define the level of freedom that can be given to a citizen without endangering the part of freedom that should be protected by the state. He claimed it was possible and he relied on examples of democratic states that managed to achieve it. He was certain that this is one of the core tasks of a legislature in democratic countries, where liberalism and and intervention by the state are not in opposition. He advocated that no freedom is possible if not protected by the state:

Freedom, we have seen, defeats itself, if it is unlimited. Unlimited freedom means that a strong man is free to bully one who is weak and to rob him of his freedom. This is why we demand that the state should limit freedom to a certain extent, so that everyone's freedom is protected by law. Nobody should be at the mercy of others, but all should have a right to be protected by the state. Now I believe that these considerations, originally meant to apply to the realm of bruteforce, of physical intimidation, must be applied to the economic realm also. Even if the state protects its citizens from being bullied by physical violence (as it does, in principle, under the system of unrestrained capitalism), it may defeat our ends by its failure to protect them from the misuse of economic power. [...] Under these circumstances, unlimited economic freedom can be just as self-defeating as unlimited physical freedom, and economic may be nearly as dangerous as physical violence" ${ }^{\prime 30}$.

Popper believed there is a need to create social institutions that will protect the freedoms of the weaker from the stronger, including economic freedoms. He considered this part of civil rights protection that did not threaten others as a core responsibility of the state. To his mind the state had the right to limit everyone's freedoms in a balanced manner without exceeding what is necessary in order to achieve equality in limiting freedoms. Another recommendation he proposes is to meticulously plan the structures of institutions designed for protecting freedoms, especially the freedom from exploitation. Social engineering of

\footnotetext{
27 Ibidem, p. 1, 287.

28 Ibidem, p. 2, 374.

${ }^{29}$ Ibidem, p. 1, 105.

30 Ibidem, p. 2, 173.
} 
this kind is our task, that is in our power, and that we must not wait for economic earthquakes miraculously to produce a new economic world for us, so that all we shall have to do will be to unveil it, to remove the old political cloak ${ }^{31}$. Democratic institutions that provide safety and freedom need to be supported. Those are the institutions that allow for the contral of power, since all forms of power are dangerous and require constant civil monitoring. All large-scale politics need to be institutionalised and not individualised. All democratic long-term politics should be inducted to institutions and not individuals. Popper firmly rejects Marx's type of holism and advocates piecemeal social engineering. He claims: "If it is easier to reach a reasonable agreement about existing evils and the means of combating them than it is about an ideal good and the means of its realization, then there is also more hope that by using the piecemeal method we may get over the very greatest practical difficulty of all reasonable political reform, namely, the use of reason, instead of passion and violence, in executing the programme" 32 . Popper perceived a solution in creating legal frameworks for institutions to protect citizens and administrative privileges of the state agencies to intervene within set borders. This is essential to achieving certain aims outlined in a particular period by the ruled. He agreed, however, with Marx in that one should not waste time analysing the possibilities of eternal existence of a world we are not content with. He rejected the fortune-telling of a better future and creating a better world through irrational means, conflicting with logic or connected with violence. $\mathrm{He}$ supported the development of technologies in order to piecemeal engineer the world as well as the development of interventionist democracy ${ }^{33}$.

Another proposition Popper makes is to limit the competence of those ruling. To control through respectively established institutions, to remove the government without bloodshed, and introduce changes on peaceful terms. "A consistent democratic constitution should exclude only one type of change in the legal system, namely a change which would endanger its democratic character" 34 . Only a system which enables the introduction of reform without the need for violence, can become a fertile soil for all rational changes. Such regulations should be introduced in order for it to be no longer profitable to undertake antidemocratic actions in place of seeking a democratic compromise. A vital element on the path to an open society is to rely on the law of justice, which Popper defined as follows:

1. equal division of social burdens, i.e. in those freedom limitations that are unavoidable in social life;

2. equality before the law, provided that the law does not favour or limit particular individuals, classes or groups of citizens over others;

3. judical impartiality;

4. equal division of benefits, which the state can offer its citizens ${ }^{35}$.

31 Ibidem, p. 2, 180.

32 Ibidem, p. 1, 182.

33 Popper considers this criticism of Marxism as particularly important. He made a mention of it in $\S 17 / 18$ „Nędzy historycyzmu”. He claimed that only adapting a historicist moral theory will free Marxism from accusations of preaching a faith.

34 Ibidem, p. 2, 224.

35 Ibidem, p. 1, 133. 
As Wiktor Osiatyński points out in his article devoted to Popper: "for an open society to exist it takes more than free land or opportunities for increases in social mobility due to new technologies. Just as fire needs wood and life nutrition the existence of an open society requires a constant upkeep of energy necessary for its existence and development. An open society would not survive without institutions, without legal limitations of power or without civil independence. In other words, an open society requires the existence of civil society. It was the creation of civil society that preceeded the beginnings of an open society on the frontiers of America in the 18th century and later on also in West European democracies" $" 36$.

Czesław Porębski makes an interesting point in his article Man In a Completely Open Society $^{37}$. He points out that the risks connected with the depersonification - free market, equal opportunities, lack of tribal ties and tribalism based on (for example) obeying authorities - can lead to the breaking of inter-human relations. According to the author of this article Popper puts special emphasis on individualism, and the necessity of cooperation, but also competition. He highlighted the freedom of those individuals to make decisions and their readiness to take responsibility in opposition to the egoism of 'monads' who isolate themselves from others.

\section{Bibliography}

Arendt H., Korzenie totalitaryzmu, Wydawnictwa Akademickie i Profesjonalne, Warszawa 2008.

Chmielewski A., Filozofia Poppera: analiza krytyczna, Wydawnictwo Uniwersytetu Wrocławskiego, Wrocław 1995.

Grinberg D., Pre-face to Polish edition from 1993, [in:] H. Arendt, Korzenie totalitaryzmu, Wydawnictwa Akademickie i Profesjonalne, Warszawa 2008.

Lippmann W., The Good Society, Brown and Co., Boston 1937.

Niebrój K., Karla R., Poppera koncepcja prawdy: kwestia podstawowego nośnika prawdziwości, Wydawnictwo Uniwersytetu Sląskiego, Katowice 2010.

Osiatyński W., Społeczeństwo otwarte wedtug Poppera, „Wiedza i Życie”, June 1996.

Pietruska-Madey E., Wiedza i człowiek: szkice o filozofii Karla Poppera, Wydział Filozofii i Socjologii Uniwersytetu Warszawskiego, Warszawa 1997.

Popper K., Społeczeństwo otwarte i jego wrogowie, PWN, Warszawa 2010.

Porębski C., Człowiek w społeczeństwie całkowicie otwartym, „Diametros” 2005, No. 5, https:// www.diametros.iphils.uj.edu.pl/diametros/article/view/141/116 [accessed August 03, 2013].

Russell B., Power: A New Social Analysis, Routledge, New York 1938.

36 W. Osiatyński, op. cit.

37 C. Porębski, Człowiek w spoleczeństwie całkowicie otwartym, „Diametros” 2005, No. 5, p. 160-168, https://www.diametros.iphils.uj.edu.pl/diametros/article/view/141/116 [accessed August 03, 2013 ]. 
Soros G., Kryzys światowego kapitalizmu: zagrożenie dla społeczeństwa otwartego, Muza, Warszawa 1999.

Szacki J., Historia myśli socjologicznej, PWN, Warszawa 2011.

Środa M., Ludzie i termity, „Wiedza i Życie”, June 1996.

\section{Streszczenie \\ Społeczeństwo w teorii Karla Poppera}

Czym są społeczeństwa zamknięte? Jakie niosą ze sobą zagrożenie? Na czym zbudować społeczeństwo otwarte? Czy powyższe pytania są ważne i aktualne? Popper twierdził, że tak. Artykuł poświęcony jest analizie idei Poppera i jego teorii społeczeństwa otwartego i zamkniętego. W pierwszej części autorka dużo uwagi poświęca społeczeństwu zamkniętemu, opisuje jego filary, takie jak: posłuszeństwo, indoktrynacja, stała forma mobilizacji, kastowość, autarkie państwa, nacjonalizm, gloryfikacja wojny. W drugiej części przybliżony został aksjologiczny wymiar społeczeństwa otwartego, w tym zasady i wartości, na których Popper oparł swą teorię.

Słowa kluczowe: społeczeństwo, społeczeństwo obywatelskie, społeczeństwo otwarte, społeczeństwo zamknięte, obywatel, wolność

\section{Summary}

\section{Society in the theory of Karl Popper}

What are closed societies? What are the threats? How does one build an open society? Are the above questions important and current? Popper claimed that they are. The article analyses Popper's theory of an open and closed society. The first part of the article considers the 'closed' society and describes its characteristics. These include obedience, indoctrination, a constant form of mobilisation, caste, state autarchies, nationalism, glorification of war. In the second part of the article, the author introduces the axiological dimension of an open society. The principles and values on which Popper based his theory are considered. Keywords: society, civil society, open society, closed society, citizen, freedom 


\section{Muzyka rockowa a polityka w Polsce: poetyka protestu i oporu w tekstach utworów rockow ych'}

Czy muzyka rockowa jest przestrzenią, w której rozgrywa się walka o wartości? Debata na temat idei wpisanych w muzykę tego gatunku toczy się od dawna. Wystarczy przypomnieć sobie konsternację, jaką w konserwatywnych kręgach wywołały wczesne poczynania Elvisa Presleya. Teksty utworów pionierów muzyki folk-rockowej - Boba Dylana czy Joan Baez - stanowią doskonały przykład muzyki zaangażowanej. Powojenna Europa Wschodnia to także zagłębie muzyki zorientowanej politycznie. W krajach bloku socjalistycznego zespoły rockowe stawały przed trudnym wyborem. Niektórzy wyśpiewywali panegiryki na cześć władzy (tak jak to w Związku Radzieckim czyniły zespoły Veselye Rebyata - Wesołe Chłopaki czy Samotsvety - Półszlachetne Kamienie ${ }^{2}$ ), inni zaś wykorzystywali medium muzyki rockowej, by sprowokować odbiorcę (jak choćby

\footnotetext{
${ }^{1}$ Artykuł opiera się na wywiadach przeprowadzonych w Krakowie i Łodzi w październiku 2013 roku oraz w Warszawie i Gdańsku w październiku 2015 roku. Dziękuję serdecznie Irenie Borowik za organizację wywiadów w Krakowie, Katarzynie Dośpiał-Borysiak za organizację wywiadów w Łodzi oraz Ewie Bełdowskiej i Pawłowi Piotrowskiemu za organizację wywiadów w Warszawie i Gdańsku. Jestem wdzięczna także Wiesławowi Weissowi, Michałowi Kirmuciowi, Grzegorzowi Brzozowiczowi, Christine M. Hassenstab i Małgorzacie Żuradzie za komentarze na temat pierwszych szkiców tego rozdziału. Moja wizyta w Polsce w 2013 roku odbyła się w ramach programu Erasmus i wymiany naukowej z Uniwersytetem Łódzkim. Dziękuję także Marit Reitan, dziekanowi mojego wydziału na Norweskim Uniwersytecie Nauki i Technologii (NTNU), za sfinansowanie mojego wyjazdu badawczego w 2015 roku. Niniejszy artykuł ukazał się w wersji anglojęzycznej w książce Civic and Uncivic Values in Poland. Value Transformation, Education, and Culture, pod red. S. Ramet, K. Ringdal, K. Dośpiał-Borysiak, Central European University Press, Budapest-New York 2018. Tłumaczeniem materiału zajęła się Marta Kmiecik, redakcją Katarzyna Dośpiał-Borysiak.

${ }^{2}$ Zob. S. Ramet, S. Zamascikov, R. Bird, The Soviet Rock Scene, [w:] S. Ramet (red.), Rocking the State: Rock Music and Politics in Eastern Europe and Russia, Westview Press, Boulder Colorado 1994, s. 183, 192-193.
} 
słoweńska grupa awangardowa Laibach ${ }^{3}$ ) bądź wykpić komunistyczne władze (tak jak bośniacka grupa Zabranjeno pušenje - Palenie wzbronione w piosence Haile Selassie 4 , w której w zawoalowany sposób skrytykowała jugosłowiańskiego prezydenta Josipa Broza Tito). Od czasu upadku komunizmu wiele się zmieniło w tworzeniu i odbiorze muzyki rockowej. Obecnie zespoły rockowe pragną przede wszystkim zapewniać publiczności dobrą zabawę (bądź wprowadzać ją w odmienny stan świadomości) i należy założyć, że liczą także na sukces komercyjny. Niemniej etos rocka pozostaje; znacząca większość tej muzyki niesie ze sobą wartości - obywatelskie (w mojej opinii widoczne w muzyce polskiej grupy Dezerter) bądź nieobywatelskie (jak w przypadku chorwackiego muzyka i weterana wojny w Jugosławii Marka Petrovicia, lidera grupy Thompson ${ }^{5}$ ) czy też wartości alternatywne. Oczywiście są również zespoły, które sprawiają pozory zaangażowanych w przekazywanie wartości. Po bliższym przyjrzeniu się ich twórczości można jednak stwierdzić, że odbiór ich muzyki jest raczej doświadczeniem o charakterze libidynalnym niż przeżyciem intelektualno-moralnym. W tym miejscu mam na myśli muzykę deathmetalową.

Do jakiego stopnia muzycy rockowi mogą wpłynąć na zmianę zachowań, nawyków czy też systemu wartości swoich odbiorców? Politycy od dawien dawna wydawali się świadomi siły przekazu, jaką niesie ze sobą muzyka popularna. Znamienny jest tu przykład Stanów Zjednoczonych; we wrześniu 1985 roku z inicjatywy żony senatora Ala Gore'a Tipper Gore oraz trzech innych wpływowych ,żon Waszyngtonu” powstał komitet Parents' Music Resource Center (PMRC) lobbujący na rzecz kontroli treści przekazywanych w muzyce popularnej. W wyniku jego działań Dee Snider, lider metalowego zespołu Twisted Sister, oraz Frank Zappa, wokalista i gitarzysta grupy The Mothers of Invention, zostali postawieni przed komisją senacką. Podczas przesłuchania Snider został poproszony o wyjaśnienie znaczenia kontrowersyjnych w opinii komisji tekstów swoich piosenek Under the Blade oraz We're not gonna takie it. Zdaniem muzyka utwory te zostały błędnie zinterpretowane i ocenione przez PMRC ${ }^{6}$. Nie mogło natomiast być mowy o pomyłce w interpretacji tekstu węgierskiej grupy punkowej Coitus Punk Group (znanej także pod nazwą CPg), która w marcu 1983 roku wyśpiewała słowa: „Zgniła, śmierdząca komunistyczna banda - dlaczego jeszcze nikt ich nie powiesił?"7. Członkowie zespołu zostali aresztowani i po sześciomiesięcznym procesie skazani na wyroki więzienia od 18 miesięcy do 2 lat. Takie przykłady można by mnożyć, ale już ten węgierski dobitnie ukazuje istotę problemu:

3 S. Ramet, Shake, Rattle, and Self-Management: Making the Scene in Yugoslavia, [w:] S. Ramet (red.), Rocking the State: Rock Music and Politics in Eastern Europe and Russia, Westview Press, Boulder Colorado 1994, s. 117-121.

${ }^{4}$ Utwór zamieszczony na płycie CD Zabranjeno pušenje, Dallas CD 139 (1997), na której ponownie wydano piosenkę.

5 Thompson, E, moj narode, HNZS Croatia Records 5475040 (2002).

${ }^{6}$ Zob. przesłuchanie Dee Snidera w Senacie. Dee Snider's PMRC Senate Hearing Speech (Full), http:// loudwire.com/twisted-sisters-dee-snider-1985-pmrc-senate-hearing/ [dostęp: 17.09.2018]. Frank Zappa zjawił się w Senacie na przesłuchanie: Frank Zappa at PMRC Senate Hearing on Rock Lyrics, zob. https://www. youtube.com/watch?v=hgAF8Vu8G0w [dostęp: 17.09.2018].

${ }^{7}$ Cytowane w: S. Ramet, Social Currents in Eastern Europe: The Sources and Consequences of the Great Transformation, Duke University Press, Durham 1995, s. 259. 
jakaś część rockowych i punkowych grup od zawsze prowokowała kontrowersyjnymi tekstami, niekiedy świadomie, niekiedy nie. Niektóre z nich naraziły się władzy i tak, jak wspomniani Węgrzy, zostały postawione przed sądem ${ }^{8}$.

Polska scena rockowa i punkowa przez lata stanowiła medium dla wartości antysystemowych. W latach 80. XX wieku, podczas stanu wojennego, grupy takie jak Maanam, Perfect, TSA czy Brygada Kryzys na różne sposoby prześmiewały władze komunistyczne; ostatni z wyżej wymienionych zespołów zaprzestał działalności w 1982 roku, właśnie ze względu na trudności okresu stanu wojennego. W 1991 roku grupa wznowiła działalność, lecz po zaledwie trzech latach ponownie się rozwiązała. Ostatecznie zespół wrócił na scenę w 2003 roku. Po przełomie roku 1989 zmienili się gracze na politycznej scenie, a wraz z nimi istota rockowej opozycji. Teraz kapitalizm zaczyna być postrzegany przez niektóre rockowe i punkowe zespoły jako wróg. Wśród tych zespołów szczególne miejsce zajmuje utworzona w 1981 roku warszawska grupa Dezerter, która wcześniej głośno krytykowała ustrój komunistyczny. Inne grupy zaangażowane w krytykę kapitalizmu i jego wyświechtanego bełkotu w postkomunistycznej Polsce to łódzki zespół Cool Kids of Death oraz anarchistyczna punkowa formacja ze Szczecina Włochaty. Poznańska trashmetalowa grupa Acid Drinkers, powstała w 1986 roku, i swarzędzka alternatywna metalowa formacja Sweet Noise, założona w 1990 roku, w swoich tekstach protestują przeciwko brakowi wolności, mentalności tłumu i innym absurdom postkomunistycznego społeczeństwa.

W latach 80. Kościół katolicki był ostoją antykomunistycznej opozycji w Polsce. Natomiast po roku 1989 instytucja Kościoła miała przemożny wpływ na kształtowanie się nowego systemu legislacyjnego, oddziałując na takie sfery, jak choćby prawo aborcyjne czy telewizja publiczna i radio. Wtedy też zaczęto nauczać religii w szkołach. W takich okolicznościach łatwe do przewidzenia było pojawienie się nastrojów antyklerykalnych. Grupa Behemoth, grająca blackened death metal, oraz deathmetalowa formacja Vader otwarcie podejmują tematy antychrześcijańskie w swojej twórczości. Lider grupy Behemoth, Adam Darski (znany także jako Nergal) zdobył rozgłos, drąc egzemplarz Biblii podczas koncertu w 2007 roku$^{9}$. Nie brakuje oczywiście na polskiej scenie reakcji na ten antychrześcijański nurt, którą uosabiają takie zespoły, jak chrześcijańska gotycka metalowa grupa Undish założona w 1991 roku oraz chrześcijański zespół rockowy 2Tm2,3, którego enigmatyczna nazwa nawiązuje do 3 wersu z 2 rozdziału drugiego listu św. Pawła do Tymoteusza (,Weź udział w trudach i przeciwnościach jako dobry żołnierz Chrystusa Jezusa!" ${ }^{10}$ ). Na polskiej scenie metalowej pojawiają się także inne ekstremistyczne nurty prawicowe; znamienny jest przykład formacji Graveland, która wskrzesza w swojej

${ }^{8}$ Innym znamiennym przykładem z tamtego okresu jest proces czechosłowackiej grupy The Plastic People of the Universe. Szczegóły w: S. Ramet, Rock Music in Czechoslovakia, [w:] tegoż (red.), Rocking the State: Rock Music and Politics in Eastern Europe and Russia, Westview Press, Boulder Colorado 1994, s. 61-64.

${ }_{9}$ Piotr Praschil, producent płytowy, w wywiadzie z autorką w kawiarni w pobliżu sklepu muzycznego Music Corner w Krakowie, 18 października 2013; Marcin Zwierżdżyński, tłumacz; oraz Jarek Szubrycht, dziennikarz, w wywiadzie z autorką, Sheraton Hotel, Warszawa, 9 października 2015; w konsultacji z Małgorzatą Żuradą, tłumaczką.

10 Według Biblii Tysiąclecia. 
twórczości dawne wierzenia pogańskie ${ }^{11}$. W rozdziale tym nie zabraknie także miejsca dla twórczości legendarnych postaci polskiej muzyki: Czesława Niemena (1939-2004), grupy Maanam, gdańskiego zespołu Czerwono-Czarni, aktywnego w latach 1960-1976, który w 1961 roku jako pierwszy zespół rockowy w Polsce wydał płytę, oraz toruńskiej Republiki działającej w latach 1978-1986, a reaktywowanej w latach 90. Jeśli chodzi o scenę deathmetalową, czołową grupą tego nurtu w drugiej połowie lat 90 . była formacja Decapitated założona w 1996 roku.

Już z tego wstępnego zarysu jasno wynika, że muzyka rockowa, świadomie bądź nieświadomie, staje się medium dla przekazu wartości; czy to promując materializm i hedonizm, czy też implikując, wywołując, popierając, sugerując albo przekazując społeczno-polityczne nastroje. Jednakże by zrozumieć, gdzie polski rock jest dziś, trzeba opowiedzieć jego historię od początku; prześledzić jego rozwój od bigbitu aż do konfrontacji z reżimem komunistycznym, skutkującej wzrostem politycznego zaangażowania tej muzyki po roku 1981. Zaangażowanie to nie osłabło po przełomie roku 1989.

\section{Początki}

Rock'n'roll, bo tak początkowo nazywano tę muzykę, dotarł do Polski już w roku 1956 dzięki Radiu Luxembourg oraz audycjom Głosu Ameryki. Polska młodzież była zauroczona Elvisem Presleyem, Tommy'm Steelem, Billem Haleyem i innymi gwiazdami tamtego okresu. Niektórzy połknęli muzycznego bakcyla i zaczęli naśladować muzykę zespołów nadawaną w tych rozgłośniach. Pionierzy muzyki rockowej w Polsce, słuchając Radia Luxembourg, opanowywali muzykę i, nie znając angielskiego, fonetycznie, z licznymi błędami, spisywali teksty piosenek, które później wykonywali ${ }^{12}$. Pomimo tych anglojęzycznych fascynacji muzycy śpiewali także piosenki w języku ojczystym. Pierwszy kontakt polskiej publiczności z przebojami Elvisa Presleya i Billa Haleya miał miejsce w 1957 roku, kiedy to kwintet Stanisława „Drążka” Kalwińskiego grający dixieland jazz włączył do swojego repertuaru utwory tych artystów.

Pierwszym polskim zespołem rockandrollowym był Rhythm and Blues z wokalistą Bogusławem Wyrobkiem na czele. Wbrew temu, co mogłaby sugerować nazwa, grupa miała więcej wspólnego z muzyką Elvisa Presleya niż z R\&B ${ }^{13}$. Debiutancki koncert zespołu odbył się 24 marca 1959 roku w klubie Rudy Kot w Gdańsku ${ }^{14}$. Dwa miesiące później muzycy zostali laureatami ogólnopolskiego konkursu zespołów jazzowych i rozrywkowych w Warszawie. Choć grupa wykonywała głównie covery amerykańskich i brytyjskich przebojów, w repertuarze miała także oryginalną piosenkę Big Boogie Woogie autorstwa Leszka Bogdanowicza, gitarzysty zespołu. Koncerty grupy wywoły-

${ }^{11}$ J. Szubrycht [przypis 9].

${ }_{12}$ Marek Michalak, jazzman i kompozytor, w wywiadzie z autorką, Hard Rock Cafe, Kraków, 17 października 2013.

${ }_{13}$ Sławek Macias, dziennikarz Radia Łódź oraz muzyk, w wywiadzie z autorką, Novotel, Łódź, 21 października 2013.

${ }^{14}$ A. Kan, N. Hayes, Big Beat in Poland, [w:] S. Ramet (red.), Rocking the State: Rock Music and Politics in Eastern Europe and Russia, Westview Press, Boulder Colorado 1994, s. 42. 
wały u fanów zbiorową histerię - do tego stopnia, że muzycy na plakatach promujących występy zamieszczali, bezskutecznie niestety, prośby o powściągnięcie emocji i spokojne zachowanie. Jesienią 1959 roku Polska Zjednoczona Partia Robotnicza na czele z Władysławem Gomułką, charakteryzująca się raczej konserwatywnym podejściem do kultury i sztuki, wydała zakaz występów zespołu w większych obiektach ${ }^{15}$. Wkrótce potem grupa się rozpadła, by utworzyć nowy skład pod nazwą Czerwono-Czarni. Czerwono-Czarni szybko stali się jednym z najpopularniejszych polskich zespołów rockowych. Największą sławą zespół cieszył się w połowie lat 60. - w 1964 roku na festiwalu w Opolu muzycy z wokalistką Katarzyną Sobczyk zdobyli nagrodę za przebój $O$ mnie się nie martw. Latem 1967 roku zespół opuścił Ryszard Poznakowski. Czerwono-Czarni powoli tracili popularność. W 1971 roku muzycy zawiesili prace nad repertuarem, chociaż występowali jeszcze przez 5 lat. W 1976 roku w Gdańsku, po 16 latach działalności, zapadła decyzja o rozwiązaniu zespołu.

Gomułce być może udało się stłumić pierwociny polskiego rock and rolla, ale na pewno nie udało mu się powstrzymać fali „mocnego uderzenia”, która w roku 1960 ogarnęła już Warszawę, Gdańsk i Łódź, rozprzestrzeniając się powoli po całym kraju. We wczesnych latach 60. wśród młodzieży królował twist. Piosenki nucone wtedy do tańca traktowały najczęściej o młodzieńczych zauroczeniach. Pierwszym wykonawcą, który postawił na lirykę zaangażowaną społecznie, był Czesław Niemen (1939-2004). W 1967 roku na festiwalu w Opolu wykonał on utwór swojego autorstwa Dziwny jest ten świat, który zapoczątkował w polskiej muzyce zwrot ku poważniejszej tematyce ${ }^{16}$. Zespoły rockandrollowego podziemia, występujące głównie w małych klubach, zaczęły tworzyć repertuar zaangażowany społecznie, co niekiedy skutkowało zamykaniem przez władze najbardziej ,wywrotowych" miejsc ${ }^{17}$.

Cztery zespoły, które zdominowały polską scenę rockową w latach 60., to: bluesrockowi Polanie (utworzeni w 1965 roku); Czerwone Gitary (utworzone w 1965 roku w Gdańsku), w twórczości których słychać silny wpływ Beatlesów; Skaldowie, założeni w 1965 roku w Krakowie przez braci Zielińskich, dyplomowanych muzyków, absolwentów Państwowej Wyższej Szkoły Muzycznej w Krakowie, o silnych wpływach elementów folkloru góralskiego ${ }^{18}$; oraz zespół Blackout, powstały w 1965 roku w Rzeszowie, który w roku 1968 nawet zdołał przypodobać się władzy protest songiem przeciwko wojnie w Wietnamie pt. Te bomby leca na nasz dom ${ }^{19}$. Jeszcze w roku 1968 Blackout zmienił nazwę na Breakout, a członkowie zespołu, nosząc długie włosy i promując zachodni styl życia, nieuchronnie narazili się na ostrą krytykę w mediach.

15 Tamże, s. 43; potwierdzone z dodatkowymi szczegółami przez S. Maciasa [przypis 13].

16 L. Gnoiński, J. Skaradzinski, Encyklopedia polskiego rocka, Wydawnictwo In Rock, Konin 1996, s. 303; S. Macias [przypis 13].

17 Tamże.

18 Wiesław Weiss, redaktor magazynu ,Teraz Rock”, w wywiadzie z autorką, Sheraton Hotel, Warszawa, 6 października 2015. Zob. także R. Rabiański, Krakowska scena muzyczna. Encyklopedia, Musica Jagellonica, Kraków 2006, s. 160-162.

19 A. Kan, N. Hayes, dz. cyt., s. 45; R. Ritter, 1968' - the Emergence of a Protest Culture in the Popular Music of the Eastern Bloc?, [w:] B. Kutschke, B. Norton (red.), Music and Protest in 1968, Cambridge University Press, Cambridge 2013, s. 217. 


\section{Lata 70. i 80. XX wieku}

W latach 70. Czesław Niemen, występujący w zespole o zmienionym składzie pod nazwą Niemen Enigmatic, oraz Skaldowie święcili triumfy na polskiej scenie rockowej. Dużą popularnością cieszyły się również Budka Suflera, SBB (improwizujący zespół, który ewoluował w kierunku rocka progresywnego) i Breakout, który odszedł nieco od rocka psychodelicznego i przesunął się w kierunku blues-rocka. Budka Suflera została założona w 1974 roku w Lublinie i początkowo była kojarzona głównie z coverami utworów takich artystów, jak John Mayall, Jimi Hendrix czy Led Zeppelin. SBB, zespół pierwotnie znany jako Silesian Blues Band, powstał w roku 1971 i zdobył sławę wykraczającą daleko poza granice Polski, koncertując w Austrii, Belgii, Danii, Finlandii, NRD i RFN, na Węgrzech, w Holandii, Szwecji, Szwajcarii i Stanach Zjednoczonych.

Władze PRL zaczęły zdawać sobie sprawę z tego, że fali rocka nie da się zawrócić; można było jedynie starać się utrzymać ją w ryzach. Pojawiły się zatem pomysły wydawania specjalnych pozwoleń na występy niektórym zespołom i finansowania klubów studenckich, które służyły za sale koncertowe. Zespoły oficjalnie uznane przez ówczesne Ministerstwo Kultury posiadały licencję na występy i w latach 80 . zarabiały około 400 zł za występ (choć niektórym płacono i po 700 zł, a największym gwiazdom nawet po 1200 zł). Zespoły nielicencjonowane przez władze mogły jedynie liczyć na $150 \mathrm{zł} \mathrm{za}$ koncert $^{20}$. Ten system wynagradzania muzyków obowiązywał do późnych lat 80 .

Muzyka punkowa. Pierwszy polski zespół punkowy został założony przez Walka Dzedzeja w 1976 roku $^{21}$. Dzedzej zaczynał jako muzyk uliczny, grając na gitarze akustycznej polskie tłumaczenia piosenek Boba Dylana. W 1976 roku Dzedzej napisał nihilistyczną piosenkę Nie jestem tym, czym ty:

Nie jestem mały, nie jestem mądry, nie jestem głupi, nie jestem w ZMS-ie, nie jestem w KOR-ze, nie jestem w partii, nie jestem, kurwa, niczym.

Tak śmiały tekst nie spodobał się władzom i już po trzech koncertach działalność zespołu musiała zostać zawieszona. Niedługo po tym Dzedzej wyemigrował do Szwecji.

Dwa lata później siedemnastoletni Robert Brylewski stworzył drugi polski zespół punkowy The Boors. Nazwa zespołu jest satyrycznym nawiązaniem do amerykańskiej grupy The Doors (boor to z angielskiego cham, grubianin). The Boors pisali antysystemowe teksty, zdobywając coraz większą popularność. W maju 1979 roku grupa została

${ }^{20}$ M. Michalak [przypis 12].

${ }^{21}$ Na temat początków punka w Polsce zob. M. Marciniak, Transnational Punk Communities in Poland: From Nihilism to Nothing Outside Punk, Lexington Books, Lanham 2015, rozdz. 1 (The Most Sensible Way to Be? The First Two Decades of Punk in Poland). 
przekształcona w Kryzys ${ }^{22}$. W tym okresie polityczne zaangażowanie członków zespołu było już bardzo widoczne. Kryzys i Deadlock byli pionierami muzyki punkrockowej w Polsce. Ich przesłanie było na tyle ,niebezpieczne”, że muzyka żadnego z zespołów nie była grana w radiu. Jedyne koncerty tych grup odbywały się w domach prywatnych bądź w małych warszawskich klubach ${ }^{23}$. Nagrania brytyjskich zespołów punkrockowych, takich jak Sex Pistols czy The Raincoats, cieszyły się dużą popularnością wśród polskiej młodzieży i zainspirowały rozwój polskiej sceny punkowej, na której pojawiły się później: Alians, WC, Apatia (zespół promujący między innymi wegetarianizm), Armia (z tekstami inspirowanymi między innymi Boska Komedia Dantego, Biblia czy J.R. Tolkienem). Większość z tych zespołów powstała już po ogłoszeniu stanu wojennego 13 grudnia 1981 roku $^{24}$. Abaddon, bydgoska grupa założona w 1982 roku, nagrała pierwszy punkowy longplay w historii polskiej muzyki popularnej ${ }^{25}$.

Jednakże dwie legendy muzyki punkowej powstały jeszcze przed ogłoszeniem stanu wojennego. Brygada Kryzys została założona w 1981 roku przez gitarzystów Roberta Brylewskiego (wcześniej członka Kryzysu) oraz Tomasza Lipińskiego (wcześniej członka punkowego zespołu Tilt). Muzycy wraz z wydaniem w 1982 roku debiutanckiej „,czarnej płyty” zespołu (nagranej zresztą bez zezwolenia władzy) zyskali reputację ,wichrzycieli”. Album zostały uznany za policzek wymierzony komunistom ${ }^{26}$. Grupa popadła w konflikt z władzą i część jej koncertów została odwołana ${ }^{27}$. Wśród utworów na „czarnej płycie” znajdują się anglojęzyczny Fallen, fallen is Babylon, Przestań śnić i prowokacyjny Nie ma nic:
Jeżeli jest coś nowego
Jeżeli jest nowy świat
Ten, na który czekamy
I o którym marzymy
Na pewno nie ten
Na pewno nie
I tak tu już nie ma nic
Do stracenia
Jeżeli jest coś pozytywnego
Jeżeli jest coś, co ma jakiś sens
Coś, co każdy wie
I czego każdy chce
Chcę zobaczyć to teraz

22 Paweł „Kelner” Rozwadowski, niegdysiejszy członek zespołów Deuter i Izrael, w wywiadzie z autorką, Sheraton Hotel, Warszawa, 7 października 2015, w konsultacji z Małgorzatą Żuradą, tłumaczką.

${ }^{23}$ W. Weiss [przypis 18].

24 Ewa Langer, członkini zespołu PRL (1992-1997), w wywiadzie z autorką, Ibis Hotel, Kraków, 19 października 2013; M. Macias [przypis 13].

25 M. Macias [przypis 13].

26 W. Weiss [przypis 18].

27 Gosia Fruzińska, menedżerka i wokalistka w Rock Pubie, oraz Ziemek Kosmowski z Rendez-Vous, w wywiadzie z autorką, Novotel, Łódź, 21 października 2013; Tomek Lipiński, założyciel grupy Tilt i współzałożyciel Brygady Kryzys, w wywiadzie z autorką, Sheraton Hotel, Warszawa, 5 października 2015. 
Chcę zobaczyć to tu

I tak tu już nie ma nic

Do stracenia ${ }^{28}$

Dezerter, założony w maju 1981 roku jako SS-20, zadebiutował w październiku tamtego roku. Władzom nie podobała się prowokacyjna nazwa SS-20, gdyż nawiązywała do radzieckiej rakiety balistycznej. We wrześniu 1982 roku muzycy zespołu, nie uginając się pod naciskiem, postanowili sprowokować jeszcze bardziej i przemianowali nazwę zespołu na Dezerter (niekiedy zapisywaną przez dziennikarzy jako De-zerter). Reżim komunistyczny bacznie przyglądał się działalności grupy, starannie selekcjonując utwory, które pozwolono muzykom zarejestrować w studiu. W krytycznych tekstach Dezertera przenikają się satyra, sarkazm, ironia, ale i poczucie desperacji. W 1983 roku zespół wydał w nakładzie 50000 egzemplarzy z czterema piosenkami. Płyta była sprzedawana w sklepach muzycznych w całej Polsce ${ }^{29}$. Po wyprzedaniu pierwszego nakładu wytłoczono drugi, który ostatecznie nie trafił do obiegu, ponieważ został skonfiskowany przez cenzurę ${ }^{30}$.

Muzyka punkowa stała się niezwykle popularna wśród polskiej młodzieży w latach 80., nie tylko dzięki warstwie tekstowej. W Jarocinie zaczęto organizować coroczny festiwal muzyki punkrockowej. Pierwszy, w 1980 roku, przyciągnął skromną liczbę 600 fanów, ale w ciągu kilku lat liczba ta wzrosła do 15 000-20 000³1. W tamtym okresie popularność zaczęła także zdobywać grupa Perfect założona w 1977 roku przez Zbigniewa Hołdysa wraz z Wojciechem Morawskim i Zdzisławem Zawadzkim.

Scena rockowa lat 80. Wprowadzenie stanu wojennego w grudniu 1981 roku wywołało w polskim społeczeństwie niemałe poruszenie. Zarówno NSZZ „Solidarność”, jak i jego rolniczy odłam spotkały represje. Niektórych działaczy internowano i więziono, a Lecha Wałęsę umieszczono w areszcie domowym. Niezależne Stowarzyszenie Studentów (NZS), wraz z kilkoma innymi inicjatywami, zostało zdelegalizowane. Względna wolność prasy, która była owocem strajków sierpniowych w Stoczni Gdańskiej, została ograniczona. Miejsce w szeregu pokazano także Zjednoczonemu Stronnictwu Ludowemu i Stronnictwu Demokratycznemu ${ }^{32}$. Usta zamknięto także muzykom rockowym. Większość zespołów nowofalowych nie mogła uzyskać pozwoleń na nagrywanie płyt, więc w obiegu zaczęły krążyć garażowe nagrania na kasetach magnetofonowych.

W roku 1980 zespół Maanam, założony cztery lata wcześniej przez Marka Jackowskiego i jego ówczesną żonę Olgę Jackowską (znaną pod pseudonimem Kora), wydał przeboje

${ }^{28}$ Brygada Kryzys, Nie ma nic, Tonpress 1982, https://www.youtube.com/watch?v=1cb7OpGvFN0 [dostęp: 10.10.2018].

${ }^{29}$ Robert Matera, kompozytor, gitarzysta i wokalista Dezertera, w wywiadzie z autorką, Sheraton Hotel, Warszawa, 8 października 2015, w konsultacji z Małgorzatą Żuradą, tłumaczką.

${ }^{30}$ M. Macias [przypis 13]; R. Matera [przypis 30]; oraz L. Gnoiński, J. Skaradzinski, dz. cyt., s. 126.

${ }^{31}$ A. Kan, N. Hayes, dz. cyt., s. 49.

${ }^{32}$ Szczegóły na ten temat zob. S. Ramet, Social Currents in Eastern Europe..., dz. cyt. (rozdz. 4 Underground Solidarity and Parallel Society in Poland). 
Hamlet ${ }^{33}$ oraz Boskie Buenos (Buenos Aires) ${ }^{34}$. Cztery lata później Maanam nagrał album Nocny Patrol ${ }^{35}$ (równolegle została wydana wersja anglojęzyczna Night Patrol), z którego pochodzi utwór o tym samym tytule:

Nocny patrol czuwa, kroczy ochoczo

Zagląda do okien, rozgląda się wokół

Wszystko w porządku, więc od początku

Tam, gdzie latarnie, gdzie świateł blask

Oddech zmęczony, tupot nerwowy

Sypie się szkło

Rozpaczy jęki, zduszone krzyki

Sączy się zło

Śpij, śpij spokojnie śpij

Oddychaj głęboko, śnij różowo śnij

Nocny patrol czuwa, wytęża wzrok

Szepty, krzyki, cienie, patrol równa krok

Wszystko w porządku, więc od początku

Tam, gdzie latarnie, gdzie świateł blask ${ }^{36}$

Nie tylko Maanam i omówione wcześniej zespoły punkowe w latach 80. krytykowały w swoich tekstach reżim komunistyczny. Zespoły takie, jak Kult, T.Love, Deuter i Republika także były znane z politycznie zaangażowanych tekstów ${ }^{37}$.

Pisanie politycznie zaangażowanych utworów wymagało wiele odwagi w czasach, kiedy reżim promował lekką muzykę rockową z „nieszkodliwymi” tekstami. Dlatego wcale nie zdziwiło mnie podczas mojej wizyty w Polsce w październiku 2013 roku, że kilkoro moich rozmówców mocno podkreślało, że lata 80 . były złotym okresem dla polskiego rocka. Pogląd ten potwierdził Raymond Patton, pisząc, że „niektórzy Polacy, zwłaszcza ci, których młodość przypadła na lata 80., pamiętają tę dekadę jako okres szczytowy polskiej muzyki. Czasy stanu wojennego były z pewnością twórczym okresem nie tylko dla rocka, ale także dla takich gatunków, jak heavy metal, reggae i punk" 38 . Ale czy nie jest to paradoks, skoro w pierwszej połowie lat 80. internowano wielu działaczy Solidarności i tzw. wrogów systemu oraz nałożono cenzurę na media i przemysł wydawniczy? Odpowiedź na to pytanie jest dość prosta, jak wyjaśnia Jolanta Pekacz. Władze komunistyczne miały stosunkowo łagodne podejście do muzyki popularnej;

33 Maanam, Hamlet, nagranie studyjne, https://www.youtube.com/watch?v=9rD-f-rUcY4 [dostęp: 10.10.2018].

34 Maanam, Boskie Buenos (Buenos Aires), https://www.youtube.com/watch?v=bVaNvnPd-Dg [dostęp: 10.10.2018].

35 L. Gnoiński, J. Skaradzinski, dz. cyt., s. 277.

36 Maanam, Nocny Patrol, No. 6.25728-BL (Arctic 1983). Piosenka jest opublikowana w Internecie na stronie https://www.youtube.com/watch?v=seNQ9gK2JBs [dostęp: 10.10.2018].

37 Leszek Gnoiński, reżyser i scenarzysta filmu Beats of Freedom - Zew Wolności oraz dziennikarz, w wywiadzie z autorką, Ibis Hotel, Kraków, 18 października 2013; Marcin Zwierżdżyński, tłumacz.

38 R. Patton, The Communist Culture Industry: The Music Business in 1980s Poland, „Journal of Contemporary History" 2012, Vol. 47, No. 2, s. 428. 
widziały w niej głównie młodzieżową rozrywkę, przestrzeń do wyładowania energii. Nie upatrywały w muzykach rockowych szczególnie groźnych „,wrogów systemu”. Dlatego nie interesowały się tak bardzo sceną muzyczną, jak innymi dziedzinami kultury, które wydawały im się znacznie większym zagrożeniem dla porządku społecznego ${ }^{39}$. Kiedy Jerzy Urban, rzecznik polskiego rządu w latach 80., a obecnie redaktor naczelny tygodnika „Nie”, został zapytany o to, dlaczego muzycy rockowi mieli w tamtym okresie tak duży margines wolności artystycznej, odpowiedział, że komuniści byli przekonani o tym, że ani rock, ani punk nie miały żadnego znaczenia i w ogóle się nie liczyły. Władze zajmowały się innymi problemami ${ }^{40}$. Nie znaczyło to, że można było bezkarnie śpiewać wszystko. Teksty były przepuszczane przez cenzurę, ale najwyraźniej cenzorzy nie wykonywali swojej pracy zbyt skrupulatnie.

W kwestii sprzedaży płyt i liczby fanów na koncertach w latach 80. pozycję dominującą na rynku osiągnęły: Maanam, Perfect, Republika i Lady Pank, warszawska grupa założona w 1981 roku przez Jana Borysewicza i Andrzeja Mogielnickiego. Republika natomiast została utworzona w Toruniu w 1978 roku. W roku 1979 liderem zespołu został kompozytor, poeta, autor tekstów i wokalista Grzegorz Ciechowski (1957-2001). Ciechowski nie stronił od krytyki ustroju komunistycznego, choć jego teksty traktowały przede wszystkim o wszelkich przejawach konformizmu oraz monotonii i bezcelowości współczesnego życia, co widoczne jest choćby w utworze Kombinat wydanym jako singiel na płycie w 1983 roku:

Kombinat pracuje

oddycha buduje

kombinat to tkanka

ja jestem komórką

nie wyrwę się

nie wyrwę się

to tylko wiem

wiem wiem wieeeeeeem

kombinat pulsuje

nikt nie wie, że żyję

nic nie wiem o sobie

mam tętno miarowe

nie wyrwę się

nie wyrwę się

to tylko wiem

wiem wiem wieeeeeeem

te biurka się ciągną

aż hen po widnokrąg

zasypiam w szufladzie

dokładnie wskazanej

39 J. Pekacz, On Some Dilemmas of Polish Post-Communist Rock Culture, „Popular Music” May 1992, Vol. 11, No. 2, s. 206.

${ }^{40}$ T. Lipiński [przypis 27]. 
nie wyrwę się

nie wyrwę się

teraz już wiem

wiem wiem wieeeeeeeeeeem ${ }^{41}$

W tym okresie rozwijała się także podziemna scena rockowa z takimi zespołami, jak Kult, Klaus Mitffoch, Dżem, Turbo, Kat, wspomniany już Dezerter i inni.

W roku 1986 kilkoro warszawskich muzyków utworzyło hardcore'ową grupę punkową Post Regiment. Rok później Dominika „Nika” Domczyk została wokalistką zespołu. Wśród wczesnych utworów grupy znajduje się Madman, w którym muzycy ostrzegają, że „W zasadzie to każdy jest szaleńcem”42. W międzyczasie zespół Kult (utworzony w 1982 roku) wydał w 1986 roku utwór Konsument ${ }^{43}$, który zwiastował zmiany w politycznym zaangażowaniu muzyków rockowych.

\section{Teksty rockowe od czasów upadku komunizmu}

W roku 1988 władze komunistyczne zaczęły tracić grunt pod nogami. Fala wiosennych i letnich strajków zmusiła komunistyczny rząd do szukania kompromisu z działaczami opozycji. Od lutego do kwietnia 1989 roku trwały rozmowy Okrągłego Stołu z działaczami Solidarności, a w czerwcu odbyły się pierwsze częściowo wolne wybory parlamentarne. W tych zmieniających się czasach polskie społeczeństwo musiało stawić czoło nowym problemom ekonomicznym związanym z powoli następującą transformacją ustrojową.

W roku 1990 popularna grupa De Mono w piosence Meksyk/Oh yeah! tak podsumowała lata 80. i czasy walki Solidarności o niezawisłość:

Już nie pamiętasz ulic w ogniu

I rozmów aż do rana

I kamieni rzucanych przed siebie na oślep

Kryjówek w ciemnych bramach

Już nie pamiętasz co to strach i ból

A kiedy szedłeś z innymi ulicą

Bić się o swoje prawa

Wracałeś późno zmęczony do domu

Walczyłeś aż do rana

Już nie pamiętasz co to strach i ból

To już nie to samo życie

To już nie jest to co było

${ }^{41}$ Wizualnie bardzo interesujące jest wykonanie Jakuba Szydłowskiego, które doskonale ilustruje znaczenie tekstu Ciechowskiego. Republika, Kombinat, https://www.youtube.com/watch?v=9kK6YyGQIQc\&list= PL8E0AD83E3948A0E6\&index=1 [dostęp: 10.10.2018].

${ }^{42}$ L. Gnoiński, J. Skaradzinski, dz. cyt., s. 340-341; oraz strona zespołu Post Regiment w serwisie http:// www.last.fm/music/Post+Regiment [dostęp: 10.10.2018].

${ }^{43}$ L. Gnoiński, J. Skaradzinski, dz. cyt., s. 257-258. 
Masz już nowe ideały

$[\ldots]$

Już dla ciebie się skończyła rewolucja ${ }^{44}$

W tym samym czasie, rapcore’owy Kazik na Żywo z przerażeniem patrzył w postkomunistyczną przyszłość, widząc w niej rosnący konsumpcjonizm i materializm:

Tak im zależy, byś ty był konsument

Nie myślał, działał jak instrument

Bo konsument mówi, że je aby jeść

Więc pomyśl - czy jesz aby jeść?

A wszyscy oni bombardowani śmieciami

Wszyscy oni zasypywani informacjami ${ }^{45}$

Zmieniła się też rola Kościoła katolickiego - jego pozycja znacznie osłabła wraz z pojawieniem się doniesień o dopuszczaniu się przez księży czynów pedofilskich. Sweet Noise, alternatywna grupa metalowa założona w roku 1990, nawiązała do tych dylematów w anglojęzycznej piosence Black Leather Boots z albumu The Triptic wydanego w 2007 roku:

Tracę ciebie czy tylko zatracam siebie?

W ciemności, w miejscu mojego przeznaczenia

Upadają mury, roztrzaskują się kości

Brat zabija brata, a złoto pozostaje złotem

Zdradzili ciebie tak, jak zdradzili mnie

Wydymali moją ukochaną i chcieli wydymać mnie

Perły toną w chciwości i żądzy

Kwiaty obumierają szybko, a ja widzę moich braci zmarnowanych

Ludzi zmęczonych byciem królikami doświadczalnymi

Ludzie umierają molestowani

Niegdyś karmili bogatych i obrzydliwych

Czarne skórzane buty

wymierzają ci spokój prosto w zęby

Oto ksiądz obciągający chłopcu

Rozpoczynający wojnę, błogosławiący bomby

Wniebowzięty

Ktoś czeka na ciebie

Wdycha wojnę, zaciąga się wojną

tak, jakby pieprzył dziwkę, odgrywając przydzieloną rolę

Kradnie twoje dziecko, gwałci twój umysł

Roztrzaskuje twoje życie na kawałki...

Potrzebuję tu twoich rąk

potrzebuję teraz twoich rąk

przeciwko korupcji i kłamstwom

${ }^{44}$ A. Kan, N. Hayes, dz. cyt., s. 52-53. Tekst piosenki dostępny na oficjalnej stronie zespołu: De Mono, Meksyk/Oh yeah!, https://demono.pl/meksyk-oh-yeah.html [dostęp: 10.10.2018].

${ }_{45}$ Kazik, Konsument (album Kazik na Żywo). Wykonanie tej piosenki na żywo jest opublikowane na stronie https://www.youtube.com/watch?v=WnNH3P809k0 [dostęp: 10.10.2018]. 
masowej zagładzie i niewolnictwu umysłu

Potrzebuję twoich rąk przeciwko dyskryminacji narodów

dyskryminacji ludzi

dyskryminacji naszego prawa do życia w miłości i pokoju ${ }^{46}$

Wśród najwybitniejszych zespołów rockowych lat 90. wymienia się: Proletaryat (utworzony w 1987 roku), Wilki, Myslovitz, Acid Drinkers, Homo Twist, Vader, Voo Voo, Armię, Kult, T.Love oraz Budkę Suflera. Inne popularne w tych latach zespoły to wspomniana już Republika, Püdelsi, Dżem oraz Ira, poprockowy zespół z Radomia. Spory rozgłos w tym czasie zdobyła również wokalistka Edyta Bartosiewicz. Maanam, Perfect oraz Lady Pank dokonały roszad w swoich składach i zdobyły nowych fanów ${ }^{47}$. Większość z wymienionych tu zespołów z sukcesem kontynuowała karierę prawie do połowy drugiej dekady XXI wieku. Do tej listy należy także dołączyć muzyków, którzy wypłynęli na szerokie wody nieco później. Wśród nich są: Hey, Cool Kids of Death, Coma, Lao Che, Nosowska, Pogodno, Ścianka, Strachy na Lachy, Vader, Behemoth oraz Closterkeller (zespół grający rocka gotyckiego) ${ }^{48}$. Warszawa nadal pozostaje stolicą polskiej muzyki rockowej, choć popularne zespoły działają także w Łodzi, Radomiu, Wrocławiu, Gdańsku, Poznaniu, Bydgoszczy i innych miastach. W latach 90. w Trójmieście powstała też ogromna scena alternatywna, z której wyłonił się między innymi zespół Apteka znany z promowania zażywania narkotyków.

Dezerter. Utworzony przez Roberta Materę (gitara), Krzysztofa Grabowskiego (perkusja) oraz Dariusza Stepnowskiego (bas) - uczniów Technikum Elektroniczno-Mechanicznego przy ul. Generała Zajączka w Warszawie - Dezerter wciąż pozostaje jednym z najbardziej znanych zespołów punkowych w Polsce. Skład zespołu zmieniał się na przestrzeni lat. W latach 1981-1986 z zespołem występował wokalista Dariusz „Skandal” Hajn. Funkcję basisty w latach 1985-1993 pełnił Paweł Piotrowski, a w latach 1994-1999 Tomasz „Tony von Kinsky” Lewandowski ${ }^{49}$. Matera i Grabowski do dziś są członkami grupy, a w roku 2000 dołączył do nich Jacek Chrzanowski. Zespół występował w kilku krajach Europy oraz w Stanach Zjednoczonych i Japonii. Grupa wydała następujące albumy: Dezerter (1987, potem wznowiony pod tytułem Kolaboracja), Kolaboracja II (1989), Blasfemia (1992), Nielegalny zabójca czasu (2004) oraz Prawo do bycia idiota (2010). Utwory Dezertera znalazły się także na ścieżkach dźwiękowych trzech polskich filmów, w tym dokumentu o polskiej muzyce rockowej Beats of Freedom-Zew Wolności, który miał premierę w 2010 roku $^{50}$.

46 Sweet Noise, Black Leather Boots (z albumu Triptic, 2007), na stronie http://artists.letssingit.com/sweetnoise-lyrics-black-leather-boots-1 tmqswc\#axzz3NrRK2E7z [dostęp: 10.10.2018]. Piosenka jest opublikowana w Internecie na stronie https:/www.youtube.com/watch?v=0-XOLkZLhAs [dostęp: 10.10.2018]. Tłumaczenie Marta Kmiecik.

47 Slavorum, Polish rock and pop music, styczeń 2014, na stronie https://www.slavorum.org/forum/topic/ polish-rock-and-pop-music/ [dostęp: 10.10.2018]; L. Gnoiński [przypis 38].

48 Tamże.

49 Zob. L. Gnoiński, J. Skaradzinski, dz. cyt., s. 126-128.

50 Krótka nota na temat filmu znajduje się w: Beats of Freedom Premieres in Poland, „Kraków Post” 12 marca 2010, na stronie http://www.krakowpost.com/article/1944 [dostęp: 10.10.2018]. 
Do roku 1989 teksty Dezertera skierowane były głównie przeciwko reżimowi komunistycznemu ze sporadycznymi wyjątkami. Po roku 1989 w twórczości zespołu zaczęły pojawiać się nowe wątki - krytyka kapitalizmu, konsumpcjonizmu oraz Kościoła katolickiego. Niekiedy muzycy przekształcali stare piosenki tak, by przystawały do nowych czasów ${ }^{51}$. Przykładem nowego zaangażowania Dezertera z pewnością jest piosenka Blasfemia, która znalazła się na płycie Prawo do bycia idiota. Utwór jest parodią katolickiej modlitwy Ojcze nasz:

Chleba naszego powszedniego

Daj nam, bo sami weźmiemy.

Odpuść nam nasze grzechy

Bo my też je odpuszczamy.

Nie wódź nas na pokuszenie,

Bo pokus jest aż nadto,

I zbaw nas ode złego

Bo robisz to zbyt rzadko!

Niech święci się imię Twoje,

Nam to nie przeszkadza.

Zawsze lepiej świętych mieć

Niż głupich wokół ołtarza.

A przyjście królestwa Twego

I spełnienie Twojej woli,

Zwłaszcza na Ziemi może

Wymknąć się spod kontroli!

Marną pociechą dla Kościoła katolickiego był fakt, że zespół, niejako „przyznając się do grzechu", nazwał utwór blasfemią.

W piosence tytułowej z albumu Prawo do bycia idiota muzycy poruszają wątki antyklerykalne i antykapitalistyczne, zwracając uwagę na wrogość kapitalizmu wobec bezbronnej jednostki i zredukowanie jej roli do trybu w wielkiej machinie:

Może wystarczy narzekania

że wszystko jest do dupy

że bezmyślna konsumpcja

i niekończące się zakupy

że narodowi katolicy

szukają wszędzie spisku

i modlą się o klęskę

żeby ich było na wierzchu

Może wystarczy narzekania

że globalizacja i korporacje

zabijają indywidualność

a władza zawsze ma rację

że kontrola na każdym kroku

PIN-y, NIP-y i PESEL-e

tajna policja skarbowa

anonimowi donosiciele

${ }^{51}$ M. Macias [przypis 13]. 
Może to wszystko jest bzdurą

a życie wygląda inaczej

może rządy są uczciwe

i nie ma ukrytych znaczeń

Może to, co chcą Ci sprzedać

powinieneś od nich kupić

nie zadawać trudnych pytań

i po prostu ich polubić

Mamy wolność słowa

i wolność bycia sobą

Mamy prawo wyboru

i prawo do bycia idiotą

Można by zaryzykować tezę, że w tej piosence Dezerter zgłasza pretensje do bycia sumieniem narodu.

Jak zatem muzycy zespołu postrzegają samych siebie i swoją rolę? W piosence Jesteśmy sekta, pochodzącej z tej samej płyty, pada na to pytanie żartobliwa odpowiedź:

Jesteśmy sektą ludzi normalnych

Nasze istnienie jest nieoficjalne

Nie chcemy wierzyć w ich obietnice

Że chcą poprawić nasze złe życie

Jesteśmy armią, która nie walczy

Grupą odmieńców, co się nie skarży

W świecie szaleństwa i sztucznych bodźców

Mentalną skazą, sektą uchodźców

W kraju gdzie normą jest nienormalność

Gdzie hipokryzja znaczy moralność,

Gdzie głos rozsądku jest zagłuszany

Jesteśmy sektą ludzi normalnych

Death metal i metaforyczny satanizm. Analizując mroczne i często makabryczne teledyski oraz przepełnione nihilizmem teksty deathmetalowych zespołów, należy pamiętać o tym, że niezależnie od tego, co członkowie tych formacji mówią publicznie, nieprawdopodobne jest, by podchodzili do swojej twórczości literalnie; przeciwnie - istotą twórczości na przykład zespołu Behemoth jest prowokowanie odbiorcy do krytycznego myślenia o rzeczywistości.

W Polsce istnieje kilka liczących się zespołów deathmetalowych: Lost Soul (utworzony we Wrocławiu w 1990 roku), Hate (powstały w Warszawie w 1990 roku), Decapitated (założony w Krośnie w 1996 roku), Imperator (łódzka grupa działająca w latach 1984-2000) oraz Frontside - deathcore’owy zespół z Sosnowca, który ostatnio wykonuje mainstreamowy heavy metal. Niezaprzeczalnie jednak najbardziej znanymi polskimi formacjami tego nurtu są Vader, utworzony w Olsztynie w 1983 roku, oraz gdański Behemoth, powstały w 1991 roku.

Vader powstał z inicjatywy Piotra Wiwczarka i Zbigniewa „Viki” Wróblewskiego. Podczas trzydziestoletniej działalności zespołu jego skład kilkukrotnie się zmieniał. 
Od roku 2011 grupę tworzą: gitarzysta i wokalista Piotr Wiwczarek, gitarzysta Marek „Spider” Pająk, basista Tomasz „Hal” Halicki oraz brytyjski perkusista James Stewart. Vader rozpoczynał jako formacja heavymetalowa; następnie muzycy zespołu zwrócili się w kierunku trash i speed metalu, a pod koniec lat 80. - death metalu. Trzecie demo grupy, zatytułowane Morbid Reich i wydane w 1990 roku $^{52}$, przyniosło Vaderowi szerokie uznanie i utorowało mu drogę do występów poza granicami kraju. Tytuł albumu wydanego w roku 2002 - Revelations (Objawienia) - jasno precyzuje dwojakie ambicje Vadera: z jednej strony muzycy sięgają po ważne tematy, a z drugiej zaś wypracowują sobie reputację zespołu pop-satanistycznego, który gra religijnymi i satanistycznymi odniesieniami. Niektóre tytuły piosenek Vadera mogą wydawać się pompatyczne lub wręcz pretensjonalne - choćby Helleluyah!!! (God is Dead) - Alleluja!!! (Bóg nie żyje), Come and see my sacrifice (Przyjdź i zobacz moje poświęcenie) czy Silent Empire (Nieme imperium), nie wspominając o utworach z albumu De Profundis [Z otchłani (wołałem do Ciebie, Panie)] z 1995 roku. W 2007 roku zespół wyruszył w trasę koncertową pod hasłem „World Destruction Tour”.

Vader z pewnością wypracował sobie pozycję ważnego gracza na polskiej scenie deathmetalowej, a teksty zespołu przykuły baczną uwagę niektórych kręgów. Generalnym przesłaniem piosenek grupy od początku było to, że ludzkość skazana jest na klęskę i że nie ma już dla niej nadziei, a wiara w przyszłość jest dla naiwnych. Rozważmy tekst utworu Abandon all hope (Porzućcie wszelka nadzieję) z dziesiątego albumu studyjnego grupy zatytułowanego Tibi et igni (Dla ciebie i ognia) wydanego w maju 2014 roku:

(„Porzućcie wszelką nadzieję, ci, którzy tu wchodzicie” - Dante)

Wasze puste, daremne życie

dobiega końca

przerażeni, drżycie

Odliczając ostatnie minuty swego czasu

Chodźcie do mnie!!!... Witajcie w piekle!!!...

Czy postradaliście rozum

czy staracie się w nim odnaleźć imię swego Boga?

Żadne anioły, ni demony nie istnieją w domu moim

Teraz jesteście moi na wieki

Porzućcie wszelką nadzieję... ${ }^{53}$

$\mathrm{Z}$ tego samego albumu pochodzi piosenka Where angels weep (Gdzie tkają anioły), w której przeczucie nadejścia Królestwa Księcia Ciemności jest jeszcze silniejsze:

...niebiosa upadły.

nasiąkłe świętą krwią

porzucone, poniżone

zwycięskie demony unoszą się wysoko

by powitać pana, który powstaje ze smolnych czeluści...

${ }^{52}$ Vader, Morbid Reich - demo jest opublikowane w Internecie na stronie https://www.youtube.com/ watch? $v=q 36$ G2IEizPk [dostęp: 10.10.2018].

${ }^{53}$ Vader, Abandon all hope, https://www.youtube.com/watch?v=cNOtFaI3Kfo [dostęp: 10.10.2018]. 
Żadne modlitwy nie pomogą

Nie ma już boga, którego można by pomścić

Ciemność nastaje

życie dobiega końca

Jak do tego doszło?

Jak niebiosa mogły upaść? ${ }^{54}$

Czy ten „pan, który powstaje ze smolnych czeluści” to biblijny Szatan, czy może należy - mniej dosłownie - traktować tę postać jako metaforę szatana ziemskiego, ludzkiego? Inny utwór Vadera Epitaph for Humanity (Epitafium dla ludzkości), także z albumu Revelations, sugeruje tę drugą interpretację:

Ślepota i fanatyzm są tymi typami aberracji,

które od zawsze spowalniały rozwój ludzkości.

I nic nie zmieniło się pod tym względem do dziś...

Obserwując przepływ ludzi

jak zdefiniujesz tłum?

Żałosne życie mrówek

utrzymujących, że są przyjaciółmi Boga:

Ich brak inteligencji

oznacza głupotę i ślepotę

Nieważne, jak bardzo się starasz

ten świat jest stracony... ${ }^{55}$

W tej piosence to nie nadprzyrodzony Szatan sprowadza ludzkość na manowce, a „ślepota i fanatyzm” ludzi. Ludzie - porównani do mrówek - którzy utrzymują, że są „przyjaciółmi Boga”, ukazują swoją „ślepotę i głupotę”, i to dlatego właśnie „świat jest stracony". Dla Vadera świat jest czarno-biały, a moralność to kwestia jednoznaczna i nieskomplikowana; człowiekowi nie przysługuje, jak śpiewał Dezerter ,prawo do bycia idiotą", ponieważ to właśnie idioci pchają świat w niewłaściwym kierunku. W końcu pojawia się pytanie kluczowe, jak publiczność Vadera interpretuje te teksty i czy w ogóle się w nie wsłuchuje.

Gdy Vader przyciągał uwagę międzynarodowej publiczności, w Gdańsku rodziła się kolejna formacja spod znaku death metalu - Behemoth, która początkowo grała bardziej tradycyjny black metal. Behemoth to twór wokalisty i gitarzysty Adama „Nergala” Darskiego, który był zaledwie czternastolatkiem, jak zespół powstawał. Współtwórcy zespołu już w nim nie grają. Obecny skład to, prócz Nergala, perkusista Zbigniew „Inferno” Promiński, basista i wokalista Tomasz „Orion” Wróblewski oraz gitarzysta i wokalista Patryk ,Seth” Sztyber.

Behemoth uchodzi w Polsce za zespół bardzo kontrowersyjny, przede wszystkim ze względu na prowokacyjne zachowanie Nergala, z którym grupa jest najsilniej utożsamiana. Podczas koncertu w Gdyni w 2007 roku charyzmatyczny frontman podarł na

${ }^{54}$ Vader, Where angels weep, http://www.songlyrics.com/vader/where-angels-weep-lyrics/ [dostęp: 10.10.2018]. Tłumaczenie na podstawie tekstu ze wskazanej strony WWW.

${ }_{55}$ Vader, Epitaph (for Humanity), https://www.youtube.com/watch?v=hDxNBWahqp0 [dostęp: 10.10.2018]. 
scenie egzemplarz Biblii, co odbiło się w polskich mediach szerokim echem. Nergal kojarzony nie tylko z postawą antyklerykalną często posądzany jest także o satanizm. W 2011 roku wokalista wystąpił jako juror w popularnym programie rozrywkowym The Voice of Poland, ale nie podpisano z nim kontraktu na kolejny sezon, ponieważ media wciąż donosiły o jego rzekomych satanistycznych powiązaniach ${ }^{56}$. W 2014 roku wokalista został deportowany z Rosji, po tym jak spędził tam noc w areszcie ${ }^{57}$. Do tej pory wytoczono mu także kilka procesów o obrazę uczuć religijnych. W wyniku pierwszego po incydencie z 2007 roku - muzyk został oczyszczony z zarzutów przez sąd rejonowy w Gdyni ${ }^{58}$. Lecz w styczniu 2013 roku sąd w Gdańsku zakwestionował werdykt z Gdyni i obrazoburczemu artyście wytoczono kolejny proces ${ }^{59}$, w którym to po raz drugi go uniewinniono. Większość przedstawicieli Kościoła katolickiego jednoznacznie potępia postawę Nergala. Gdy ksiądz Adam Boniecki, redaktor naczelny liberalnego katolickiego „Tygodnika Powszechnego”, publicznie bronił prawa muzyka do wyrażania swojej artystycznej wizji, biskup włocławski Wiesław Mering udzielił mu ostrej reprymendy, twierdząc, że „ksiądz sieje zamęt wśród wiernych" ${ }^{60}$.

Trzeba przyznać, że teksty Behemotha w sposób znacznie bardziej dosadny atakują religię i Kościół niż twórczość zespołu Vader. Religia katolicka szczególną cześć oddaje matce Jezusa Chrystusa, Najświętszej Maryi Dziewicy. Oczywista zatem jest reakcja środowiska katolickiego na ten utwór Behemotha pochodzący z albumu o wymownym tytule The Satanist (Satanista) z 2014 roku:

Ujrzałem pizdę dziewicy wydającą na świat węża

Byłem świadkiem upadku plemienia Judy

Widziałem dwunastu apostołów trawionych przez ogień

oraz syna bożego nadaremno zamordowanego

Zadmij w swe trąby Gabrielu!

Hosanna (Hosanna)

Niechaj wino Sodomy wypełni nasze usta

Hosanna (Hosanna)

Niechaj grzech Gomory zagości w naszych sercach ${ }^{61}$

${ }^{56}$ J. Szubrycht [przypis 9].

57 „The Guardian”, 24 września 2011, http://www.theguardian.com/commentisfree/belief/2011/sep/24/ sunday-satanist-voice-new-poland/print [dostęp: 10.10.2018]; Polskie Radio, 7 października 2011, http:// www.thenews.pl/1/9/Artykul/56420,'Satanic'-rocker-'heals'-wheelchairbound-guitarists [dostęp: 10.10.2018]; Polskie Radio, 14 października 2011, http://www.thenews.pl/1/9/Artykul/56807,Public-TV-sacks-Satanicrocker-from-talent-show [dostęp: 10.10.2018].

${ }^{58}$ Polskie Radio, 19 sierpnia 2011, http://www.thenews.pl/1/9/Artykul/53634,Bibleripping-rock-starcleared-in-court [dostęp: 10.10.2018].

${ }^{59}$ Polskie Radio, 8 stycznia 2013, http://www.thenews.pl/1/9/Artykul/123543, Death-metal-star-to-beretried-for-insulting-religion [dostęp: 10.10.2018].

${ }^{60}$ Polskie Radio, 19 sierpnia 2011, http://www.thenews.pl/1/9/Artykul/53634,Bibleripping-rock-starcleared-in-court [dostęp: 10.10.2018].

${ }^{61}$ Behemoth, Blow Your Trumpets Gabriel, http://www.lyricsfreak.com/b/behemoth/blow+your+trumpe ts+gabriel 21077142.html [dostęp: 10.10.2018]. 
I dla Vadera, i dla Behemotha metaforyczny satanizm jest elementem nieodłacznym stylistyki death metalowej (oraz blackened death metal w przypadku Behemotha). Zatem Kościół katolicki, bezpośrednio lub pośrednio, pada ofiarą ataków w tekstach obu zespołów.

Postać Szatana, do której nawiązują obie grupy, nie powinna być odczytywana literalnie. Szatan ów jest metaforą wiary w samego siebie oraz wyrazem własnej tożsamości, indywidualności oraz niezależności ${ }^{62}$. Utrzymanie niezależności od propagandy, mediów czy Kościoła to akt niezgody. Tak jak aktem niezgody był bunt Lucyfera przeciwko Bogu opisywany w chrześcijańskich annałach. Zatem wers śpiewany przez Behemotha - „Wierzę w Szatana" - także nie może być dosłownie odbierany. To wyraz ducha buntu. W rozmowie ze mną w październiku 2015 roku autor tekstów Behemotha, Krzysztof Azarewicz, podkreślił metaforyczny charakter tego „wyznania wiary” i zapewnił, że ani on, ani inni członkowie zespołu nie są wyznawcami Szatana ${ }^{63}$.

Skinheadzi. Skrajną rasistowską subkulturę skinheadów szacuje się na około 2000 osób $^{64}$, choć grupa ta może być większa o około 4000 osób o nieco mniej skrajnych poglądach. Warszawa i Kraków, tak jak w przypadku sceny rockowej, są głównymi obszarami działalności tej subkultury, choć skinheadzi regularnie pojawiają się także w co najmniej dziesięciu innych miastach, ale nie są tam tak widoczni. Pojawienie się skinheadów w Polsce datuje się na połowę lat 80., a ich najbardziej skrajne odłamy uaktywniły się znacząco pod koniec lat 80. XX wieku. Tak jak w innych krajach subkultura skinheadów charakteryzuje się postawą ksenofobiczną i antysemicką. W kontekście polskim skinheadzi są szczególnie wrogo nastawieni do punków. Wynika to z tego, że większość skinheadów to „dawni fani punk rocka, dla których muzyka ta stała się «zbyt bezpieczna»" ${ }^{65}$. Kontrkulturowość skinheadów jest bardzo specyficzna; podważają oni i kwestionują podstawowe wartości społeczne, snując fantazje o totalnej reorganizacji struktury społecznej. Jednakże te idee często są „sformułowane w sposób rozmyty i niejasny”66. Agresja wobec imigrantów stanowi dla skinheadów symboliczny wyraz idei kulturowo i rasowo homogenicznego społeczeństwa i podtrzymywania grupowej solidarności. Jak zauważa Alexei Lastovsky, koncerty zespołów skinheadzkich są zwykle poprzedzone krótkim ideologicznym wstępem o tematyce rasistowskiej, na który uczestnicy niekiedy odpowiadają nazistowskim pozdrowieniem Heil Hitler ${ }^{67}$. Wśród zespołów skinheadzkich w Polsce (niektóre mogły już zawiesić działalność) wyróżnia się BTH, Grunwald, Ramses and the Hooligans, Szczerbiec, White Power, Slav Power, Zyklon B, Fatherland, Poland,

${ }^{62}$ Krzysztof Azarewicz, autor tekstów grupy Behemoth, w wywiadzie z autorką, Sheraton Hotel, Sopot, 12 października 2015.

63 Tamże.

${ }^{64}$ The Nizkor Project, The Skinhead International: Poland, http://www.nizkor.org/hweb/orgs/american/ adl/skinhead-international/skins-poland.html [dostęp: 10.10.2018], s. 1.

65 R. Pankowski, The Populist Radical Right in Poland, Routledge, Abingdon-New York 2010, s. 98. Zob. też The Nizkor Project, dz. cyt., s. 2.

${ }^{66}$ A. Lastovsky, Ideas and Practices of the Skinhead Youth Counterculture in Belarus, „Political Sphere” 2008, No. 11, s. 102.

${ }^{67}$ Tamże, s. 112. 
Sex Bomba, Zadruga, Honor, Sztoem 68 oraz Legion. Zespoły Konkwista 88 i Falanga 88, oba z Wrocławia, określają siebie jako narodowosocjalistyczne (,,88” to neonazistowski kod oznaczający Heil Hitler - H jest ósmą literą alfabetu $)^{68}$.

Chrześcijańskie, antyklerykalne, antysystemowe i neośredniowieczne zespoły. Nawiązywałam już wcześniej w tej pracy do polskich zespołów chrześcijańskich oraz sceny antyklerykalnej. Istnienie obu tych orientacji odzwierciedla polaryzację społeczeństwa polskiego w kwestii wartości religijnych i moralnych. Według muzyków chrześcijańskich moralność jest tożsama z religią chrześcijańską. Dla antyklerykałów nie ma znaku równości pomiędzy chrześcijaństwem a moralnością, gdyż kładą oni duży nacisk na wartości uniwersalne. Wśród artystów rockowych zdarzają się jednak osobowości, które nie utożsamiają się z żadną z tych grup - na przykład Tomasz Lipiński, założyciel i długoletni lider zespołu Tilt oraz współzałożyciel Brygady Kryzys, jest buddystą. Lipiński utrzymuje, że nauki Dzogczen, wywodzące się z tradycji tybetańskiego buddyzmu, miały „pośredni wpływ” na jego twórczość rockową ${ }^{69}$ Lipiński wydaje się tu wyjątkiem, ponieważ zdecydowana większość rockmanów, dla których inspiracją jest religia, to muzycy chrześcijańscy.

Zespoły chrześcijańskie. Dariusz „Maleo” Malejonek, jedna z czołowych postaci polskiej sceny rockowej i weteran takich zespołów, jak Armia, Izrael i Houk oraz założyciel i lider Maleo Reagge Rockers, był głównym pomysłodawcą wspomnianego już projektu 2Tm2,3 - znanego także pod nazwą Timothy - dedykowanego głoszeniu Ewangelii ${ }^{70}$. Zespół powstał w 1996 roku z inicjatywy Malejonka we współpracy z Tomaszem Budzyńskim oraz członkami zespołów Acid Drinkers, Flapjack, Armia i Houk. Choć Malejonek w latach młodości uważał się za anarchistę, czuł się ideologicznie zagubiony. Nawrócenie dało mu nadzieję, ponieważ, jak mówi „Bóg kocha mnie pomimo tego, że jestem grzesznikiem"71. Muzycy 2Tm2,3 wykonują niektóre utwory po aramejsku i hebrajsku. W opanowaniu warstwy fonetycznej tekstów pomaga im zaprzyjaźniony Żyd. Zespół grywa w kościołach, ale także na festiwalach oraz koncertach lokalnych. Przesłaniem grupy jest głoszenie miłości bliźniego.

Malejonek odegrał także istotną rolę w tworzeniu dziecięcego zespołu Arka Noego, w którym występuje wraz z zaprzyjaźnionymi muzykami i ich dziećmi. I choć ksiądz Andrzej Draguła na łamach „Tygodnika Powszechnego” oskarżył Arkę Noego o trywializację Ewangelii, papież Jan Paweł II był pod wrażeniem koncepcji zespołu i zaprosił Arkę do Watykanu. Występ dla papieża i wiernych odbył się w styczniu 2001 roku $^{72}$.

${ }^{68}$ The Nizkor Project, The Skinhead International, dz. cyt., s. 3.

69 T. Lipiński [przypis 27].

${ }^{70}$ Dariusz "Maleo” Malejonek, w wywiadzie z autorką, Sheraton Hotel, Warszawa, 10 października 2015, w konsultacji z Małgorzatą Żuradą, tłumaczką.

71 Tamże.

72 Tamże. 
Tendencje antyklerykalne w muzyce rockowej. Poza dokonaniami Behemotha i Vadera na scenie deathmetalowej tendencje antyklerykalne pojawiają się także wśród zespołów grających bardziej tradycyjne odmiany rocka. Zespół Piersi, z Pawłem Kukizem na czele, który w roku 2015 kandydował w wyborach prezydenckich, w roku 1992 wydał antyklerykalną piosenkę ZCHN się zbliża. Ogólnopolski Komitet Obrony przed Sektami pod kierownictwem Ryszarda Nowaka prześwietlił setki zespołów, tworząc listę artystów antyklerykalnych, na której znajdują się m.in. Kora, Behemoth, Kat i inni.

Na specjalną uwagę zasługuje w tym miejscu zespół Big Cyc oraz jego lider Krzysztof Skiba, zawodowy prowokator. Pierwszy koncert grupy miał formę kabaretowego happeningu pod hasłem „Uroczysta akademia z okazji 75-lecia wynalezienia damskiego biustonosza". Muzycy zaprosili na niego ogólnopolskie media, których przedstawiciele tłumnie przybyli na sensacyjnie zapowiadające się wydarzenie. Obyło się jednak bez prezentowania biustonoszy i biustów, co zresztą było z góry założone. Muzycy z radością przyjęli fakt, że na wieść o braku zapowiadanych atrakcji osiemdziesięcioro pięcioro dziennikarzy postanowiło opuścić imprezę. Troje zostało do końca. Ta zabawna mistyfikacja przyniosła nowo powstałej grupie spory rozgłos i na pamiątkę tego wydarzenia muzycy nazwali zespół Big Cyc ${ }^{73}$. Od tamtego czasu grupa wydała kilka prowokacyjnych albumów; na okładce pierwszego znalazł się wizerunek Lenina z fryzurą na irokeza. $\mathrm{Na}$ drugiej, zatytułowanej Nie wierzcie elektrykom, figuruje Lech Wałęsa, a inna przedstawia zakonnicę wieszającą prezerwatywy na sznurku. I tę właśnie płytę o wymownym tytule Wojna Plemników publicznie potępiło Zjednoczenie Chrześcijańsko-Narodowe. W repertuarze Big Cyca znajduje się także utwór Moherowe Berety, w którym artyści bezlitośnie wyśmiewają zwolenników kseno- i homofobicznego ojca Tadeusza Rydzyka, szefa Radia Maryja. „Na naszych albumach jest wiele piosenek antyklerykalnych” - powiedział Skiba podczas wywiadu, który przeprowadziłam z nim w Sopocie: „Nie lubimy Kościoła, ale generalnie drwimy ze wszystkich"74. Prócz Kościoła, moherowych beretów, Wałęsy i komunistów obiektem kpin Big Cyca są też działacze Solidarności, Władimir Putin oraz wszelkie przejawy krwiożerczego kapitalizmu. Big Cyc to także autorzy niezapomnianego przeboju z przesłaniem antyrasistowskim Makumba, który niegdyś królował na listach przebojów 250 rozgłośni radiowych w Polsce ${ }^{75}$.

Po wyborach parlamentarnych z 2015 roku wygranych przez Prawo i Sprawiedliwość (PiS), Krzysztof Skiba otwarcie opowiedział się po stronie opozycji. Kiedy opozycja zjednoczona pod szyldem Komitetu Obrony Demokracji (KOD) zorganizowała 7 maja 2016 roku antypisowską i prounijną manifestację na ulicach Warszawy, Skiba wraz z zespołem Big Cyc włączyli się w akcję ${ }^{76}$, występując podczas demonstracji, która zgro-

73 Krzysztof Skiba, lider zespołu Big Cyc, w wywiadzie z autorką, Sheraton Hotel, Sopot, 14 października 2015, Małgorzata Żurada, tłumaczka.

74 Tamże.

75 Tamże. Piosenki Makumba można posłuchać na stronie https://www.youtube.com/watch?v=i4z3qo8VNfg [dostęp: 10.10.2018].

${ }^{76}$ „Newsweek” (edycja polska), nr 21/2016, http://www.newsweek.pl/plus/spoleczenstwo/big-cyc-ikrzysztof-skiba-wsparli-kod-dlaczego-,artykuly,385600,1,z.html [dostęp: 10.10.2018]. 
madziła 240000 ludzi $^{77}$. Big Cyc był jedynym zespołem rockowym, który wziął udział w tym proteście. Tydzień po tym wydarzeniu zespół wypuścił na rynek album Czarne Słońce Narodu z dziesięcioma politycznie zaangażowanymi piosenkami ${ }^{78}$. W jednej $\mathrm{z}$ nich, opublikowanej w Internecie ${ }^{79}$, Skiba prześmiewa Antoniego Macierewicza, który od roku 2013 jest wiceprezesem PiS, a w latach 2015-2018 pełnił funkcję Ministra Obrony Narodowej. W tekście piosenki czytamy:
Kto w lodówce trzyma nową bombę z klocków atomową kto doradców ma z przedszkola kogo prezes „Antoś” woła a kto oczy ma taliba kto na pomoc Marsjan wzywa kto obrabia biura NATO komu wszystko pachnie zdradą
Antoni wzywa do broni Antoni ojczyznę obroni
Antek z całym światem walczy już mu Rosja nie wystarczy on napadnie dziś na Szwecję złupi Madryt, kopnie Grecję zrobi przewrót w Ameryce piekło czystek w Kostaryce aż mu Pan Bóg powie w niebie „Ty napadnij sam na siebie"

Antoni wzywa do broni Antoni ojczyznę obroni

Nic więc dziwnego, że politycy partii rządzącej nieprzychylnie wypowiadają się o Big Cycu, nazywając zespół „niepoważną” bandą „,wulgarnych komediantów”80.

Tendencje antysystemowe w muzyce rockowej. Istnieje w Polsce spora grupa zespołów rockowych, punkowych i heavymetalowych, które wykazują szeroko rozumiane „tendencje antysystemowe”. Mam na myśli parodię i krytykę sceny politycznej, ustroju, Kościoła katolickiego, polskiej mentalności oraz podejścia do historii narodu pojawiającą się w twórczości tych grup. Niektóre z nich - na przykład The Boors czy Dezerter - zostały wspomniane już wcześniej. Kazik Staszewski, znany po prostu jako Kazik, powiedział mi

77 „Wiener Zeitung”, 7 maja 2016, http:/www.wienerzeitung.at/nachrichten/europa/europastaaten/817334 Wir-bleiben-in-Europa.html [dostęp: 30.10.2016]; Reuters, 7 maja 2016, http://www.reuters.com/article/ us-poland-protest-idUSKCN0XY0EY [dostęp: 10.10.2018].

${ }^{78}$ Krzysztof Skiba, wywiad telefoniczny z autorką, 17 maja 2016.

79 Zob. Big Cyc, Antoni wzywa do broni, https://www.youtube.com/watch?v=V3YxFizj6pk [dostęp: 10.10.2018].

${ }^{80} \mathrm{~K}$. Skiba [przypis 78]. 
w wywiadzie, że uważa swój zespół Kult za antyestablishmentowy ${ }^{81}$. Kiedy komunizm miał się ku upadkowi, a władzę powoli przejmowali działacze Solidarności, subkultura punkowa, a wraz z nią Kazik, pozostawała w opozycji do ustępującego reżimu, nie utożsamiając się jednak ideologicznie z twórcami III Rzeczypospolitej. Krzysztof „Zygzak” Chojnacki z zespołu TZN Xenna wspomina nienawistne spojrzenia zwolenników Solidarności rzucane w stronę punków na początku lat 80 . Solidarność była ruchem wolnościowym, ale najwidoczniej nie dla wszystkich ${ }^{82}$. Muzyka Kultu była inspirowana twórczością brytyjskich zespołów Spear of Destiny i Test Department oraz słoweńskiej awangardowej industrialnej grupy Laibach. Dla Kazika muzyka jest powołaniem. I choć artysta nie spodziewa się, że idee, o których pisze, trafią do dużej rzeszy odbiorców, pozostaje wierny swojej misji - krytykowaniu tego, co w systemie bezduszne i nieludzkie. Kazik twierdzi, że „my Polacy odnieśliśmy wiele zwycięstw, a pomimo tego wciąż mamy kompleksy. Jesteśmy narodem bardzo zakompleksionym" ".33 Ten pogląd można odnaleźć w jednej z piosenek Kazika, w której potępia on „głupią dumę narodową i narodowe kompleksy, które ciągną się za Polską od lat" ${ }^{\text {". }}$. Hymnem z pewnością można nazwać piosenkę zespołu Kult z 1986 roku o wymownym tytule Polska. Kazik opisuje w niej ojczyznę jako podłe, zaniedbane miejsce, w którym nic od czasów głębokiego komunizmu się nie zmieniło ${ }^{85}$.

Paweł „Kelner” Rozwadowski, założyciel powstałej w 1979 roku punkowej grupy Fornit, autor książki wspomnieniowej To zupetnie nieprawdopodobne (wyd. 2012) oraz muzyk formacji Deuter (łączącej punk, funk oraz reagge) i Izrael (z pogranicza reagge i rocka), wzbudzał w czasach komunizmu ogromne kontrowersje. Utwór Fallen is Babylon, wykonywany przez Rozwadowskiego, sam muzyk interpretuje jako piosenkę o generale Wojciechu Jaruzelskim, który był Prezesem Rady Ministrów w latach 1981-1985 oraz Przewodniczącym Rady Państwa w latach 1985-1989 ${ }^{86}$. Artysta uważa jednak, że muzycy rockowi nie są w stanie toczyć skutecznej wojny z systemem i pozostaje sceptycznie nastawiony do przejawów antysystemowej krytyki w tekstach rockowych. Polską politykę określa mianem „,cyrku niemożliwości”, w którym „nawet najprostsze rzeczy okazują się bardzo trudne do zrobienia”. Polityków definiuje jako niekompetentnych oszustów: „Nasi politycy nie wiedzą, o czym mówią... Polska to jeden wielki szpital psychiatryczny"87.

${ }^{81}$ Kazik Staszewski, założyciel i lider zespołu Kult, w wywiadzie z autorką przeprowadzonym w domu artysty, Warszawa, 5 października 2015.

${ }^{82}$ Krzysztof „Zygzak” Chojnacki, lider zespołu TZN Xenna, w wywiadzie z autorką, Sheraton Hotel, Warszawa, 6 października 2015, Krzysztof „Panek” Pankiewicz, tłumacz. Zob. też M. Marciniak, dz. cyt., s. $87-89$.

${ }^{83}$ K. Staszewski [przypis 81].

${ }_{84}$ Tamże.

85 Tamże.

${ }^{86}$ P. Rozwadowski [przypis 22].

${ }^{87}$ Tamże. 


\section{Wciąż polityczni, lecz nie zawsze}

Wśród piosenek zaangażowanych politycznie często wymienia się Czerwone tango piosenkę nagraną w 1995 roku przez zespół Püdelsi powstały z inicjatywy Andrzeja „Pudla” Bieniasza. Utwór mówi o sukcesie Sojuszu Lewicy Demokratycznej w wyborach parlamentarnych w 1993 roku $^{88}$. Lewica jest w utworze nazwana „starą dziwką":

Znów powróciłaś stara dziwko

Nie było ciebie tyle lat

Już raz mi odebrałaś wszystko

I znowu stoisz w moich drzwiach

$\mathrm{Na}$ twarzy nową masz tapetę

Karminowa czerwień warg

Znów moją pragniesz być kobietą

Choć masz pięćdziesiąt parę lat

Czerwone Tango - my bez siebie nie umiemy żyć

Czerwone Tango - czerwona życia mego nić

Czerwone Tango - gabinetowych figur czar

Czerwone Tango - daj usta, niech przeminie ból i żal ${ }^{89}$

Piosenka, z warstwą melodyczną w hipnotycznym rytmie tanga, stawia pytanie, na ile „nowa” lewica zmieniła się od czasów komunizmu.

Wspomniany już wcześniej Paweł Kukiz, charyzmatyczny prawicowy rockman i działacz społeczny, który zasłynął w latach 80 . i 90 . jako lider zespołu Piersi, ${ }^{90}$ ostatnio okrył się złą sławą, głosząc poglądy antyimmigranckie i negatywnie wypowiadając się w kwestii uchodźców. Partia utworzona przez Kukiza w 2015 roku - Kukiz'15 - zdobyła 42 miejsca w sejmie w październikowych wyborach z 2015 roku. Sam Kukiz uplasował się na trzecim miejscu w wyborach prezydenckich w maju 2015 roku i pomimo tego wyniku - w jednym z sondaży przeprowadzonym w roku 2016 - został uznany Polakiem, z którym rodacy najchętniej napiliby się piwa. Artysta wyprzedził obecnego prezydenta Andrzeja Dudę oraz byłego prezydenta Aleksandra Kwaśniewskiego, którzy zajęli w tym rankingu odpowiednio drugie i trzecie miejsce ${ }^{91}$. W kwestii uchodźców stanowisko partii Kukiza jest uważane za bardziej radykalne niż to zajmowane przez $\mathrm{PiS}^{92}$.

Lecz nie wszystko kręci się wokół polityki i religii. W Polsce istnieje także stosunkowo niewielka scena neośredniowiecznego folk rocka, na której wyróżniają się powstały w 2001 roku Slavland oraz założony w 2005 roku Percival. Te zespoły całkiem serio an-

${ }^{88}$ P. Praschil [przypis 9]; także Andrzej „Pudel” Bieniasz, w wywiadzie telefonicznym z autorką w hotelu Ibis, Kraków, 16 października 2013.

${ }^{89}$ Püdelsi, Czerwone tango, https://www.youtube.com/watch?v=5r2OQqIhfog [dostęp: 10.10.2018].

90 „Kraków Post”, 7 września 2015, http://www.krakowpost.com/9918/2015/09/the-cult-of-kukiz [dostęp: 10.10.2018].

${ }_{91}$ Polskie Radio, 2 lutego 2016, http://www.thenews.pl/1/9/Artykul/239013,Politician-poll-Kukiz-rankedas-Poles-preferred-drinking-partner [dostęp: 10.10.2018].

92 Voice of America, 12 lipca 2016, http://www.voanews.com/content/poland-clash-of-culturesescalates/3415435.html [dostęp: 10.10.2018], s. 1 . 
gażują się w przywracanie ducha średniowiecznej kultury. Członkowie Percivala odbyli, wraz z muzykologami, kilka wyjazdów badawczych na polską i białoruską wieś, podczas których odnaleźli pochodzące z lat 60. ubiegłego wieku zapisy nagrań lokalnych mieszkańców śpiewających przedchrześcijańskie pieśni znane z tradycji ustnej. Przeglądając archiwa średniowiecznych tekstów i konsultując się ze specjalistami, muzycy wybrali oryginalne teksty, do których skomponowali muzykę w stylu średniowiecznym. Poza neośredniowiecznym folk rockiem grupa ta - pod nazwą Percival Schuttenbach - gra także neośredniowieczny folk metal ${ }^{93}$.

Równie apolityczna, choć w inny sposób, jest postawa zespołu Myslovitz, znanego z przenikliwych i zapadających w pamięć tekstów, które traktują o istocie ludzkiego życia. Myslovitz, dla którego jedną z muzycznych inspiracji był Britpop, został założony w 1992 roku w siedemdziesięciopięciotysięcznych Mysłowicach. Początkowo grupa występowała pod nazwą The Freshman (Nowicjusz), ale w 1994 roku muzycy przyjęli nazwę Myslovitz, która jest wariacją na temat zniemczonej nazwy ich rodzinnego miasta. Początkowo grupę tworzyli wokalista i gitarzysta Artur Rojek, basista Marcin Porczek oraz perkusista Rafał Cieślik; Rojek opuścił zespół w 2012 roku i rozpoczął karierę solową. Zastąpił go Michał Kowalonek. Grupa śpiewa po polsku i po angielsku4. Muzycy zdobyli uznanie na arenie międzynarodowej, kiedy zostali ogłoszeni Najlepszym Polskim Zespołem podczas rozdania nagród MTV Europe Music Awards w 2002 i 2003 roku. W 2005 roku Myslovitz został laureatem Nagrody Komisji Europejskiej European Breakthrough za album Korova Milky Bar, z którym grupa dotarła do dziesięciu nowo przyjętych krajów UE. W komentarzach członków zespołu na temat Polski echem odbijają się wypowiedzi „Kelnera” Rozwadowskiego: „Ten kraj jest jak psychodeliczny lot”95.

W tekstach Cool Kids of Death, alternatywnego zespołu rockowego utworzonego w Łodzi w 2001 roku, również można znaleźć refleksje na temat życia w postkomunistycznej Polsce. Odpowiedzią muzyków na współczesne dylematy jest piosenka Generacja Nic ${ }^{96}$. Cool Kids, czyli wokalista Krzysztof Ostrowski, basista Kuba Wandachowicz, gitarzysta Marcin Kowalski, klawiszowiec Kamil Łazikowski oraz Wojciech Michalec (gitara, efekty dźwiękowe, chórki) to wprawni muzycy, których utwory instrumentalne cieszą się takim samym uznaniem, jak te wokalne. Dobrym tego przykładem jest kompozycja instrumentalna Saint Etienne (Underworld mix), której melodia przypomina tę towarzyszącą napisom końcowym przeboju Ridleya Scotta z 1982 roku, Łowca Androidów ${ }^{97}$.

Trudno jednoznacznie stwierdzić, które polskie zespoły rockowe, punkowe czy metalowe zasługują na miano supergrup, ale z pewnością do zespołów aktywnie działających

93 Mikołaj Rybacki i inni członkowie zespołu Percival, w wywiadzie z autorką, Sheraton Hotel, Warszawa, 9 października 2015, Małgorzata Żurada, tłumaczka.

94 Zob. Myslovitz, I'd like to die of love, https://www.youtube.com/watch?v=7eh7EwijR04 [dostęp: 10.10.2018].

95 Myslovitz, Acidland, tekst w wersji polskiej na stronie http://www.tekstowo.pl/piosenka,myslovitz,acidland. html [dostęp: 10.10.2018].

${ }^{96}$ Cool Kids of Death, Generacja nic, https:/www.youtube.com/watch?v=95zuqxSf9gg [dostęp: 10.10.2018].

${ }_{97}$ Cool Kids of Death, Saint Etienne (Underworld mix), https://www.youtube.com/watch?v=OPwGINprMYM [dostęp: 10.10.2018]. 
w ostatnich kilkunastu latach zaliczyć można (w kolejności alfabetycznej): Armię, Behemotha, Brygadę Kryzys, Dezertera, Kult, Perfect, Riverside, Vadera oraz Wilki.

\section{Podsumowanie}

Muzyka rockowych, punkowych i metalowych zespołów w Polsce zazębia się z twórczością artystów tych nurtów z całego świata. Pewne cechy wspólne widać także pomiędzy muzyką polską a muzyką krajów byłego bloku socjalistycznego. W niektórych aspektach jednak scena rockowa (do której zaliczam też punk i metal) w Polsce wyróżnia się.

Tak jak muzycy rockowi w Europie, Ameryce Północnej oraz w innych zakątkach świata, polscy artyści inspirowali się twórczością Beatlesów, Rolling Stonesów, Led Zeppelin, Deep Purple, The Police, Sex Pistols czy grupy Laibach. W przypadku grup Riverside, Collage i Yes widać wpływy Jethro Tull; zespoły punkowe czerpały z twórczości The Clash oraz Exploited; Hey i Coma inspirowały się muzyką Nirvany; Myslovitz zaś twórczością Oasis. Na scenie metalowej źródłem inspiracji jest twórczość Iron Maiden, Black Sabbath i Metalliki. Bob Marley i muzyka reagge to punkt odniesienia choćby dla Kazika czy Malejonka. Oczywisty jest fakt, że kolebką rocka, punk rocka i metalu był Zachód. Podgatunki takie jak neośredniowieczny folk rock, reprezentowane w Polsce przez grupy Percival i Slavland, swe korzenie również mają w Europie zachodniej (np. niemiecki Corus Corax) czy krajach skandynawskich (np. szwedzka grupa Hedningarna, duńska Sorten Muld i norweska Lumsk).

Zespoły rockowe bloku wschodniego naturalnie czuły potrzebę komentowania komunistycznej rzeczywistości i dyktatury jednej partii. W latach 80. pewną prawidłowością było prześmiewanie bądź nawet otwarte krytykowanie przez muzyków rockowych komunistycznych władz Związku Radzieckiego, Węgier, Czechosłowacji i Jugosławii. Tak samo postępowali polscy artyści. Ta krytyka, nie tylko władz, ale i włodarzy Kościoła, wciąż pozostaje domeną twórców sceny rockowej nie tylko w Polsce, ale i w krajach byłej Jugosławii oraz do pewnego stopnia w putinowskiej Rosji (jak pokazuje znamienny przykład rosyjskiej grupy Pussy Riot).

Polskiego rocka jednak coś wyróżnia na tle muzyki innych byłych demoludów. Po pierwsze, w Polsce zawsze istniał relatywnie przyjazny klimat artystyczny w porównaniu do innych krajów komunistycznych; klimat ten był nawet lepszy niż obecny w niektórych krajach Europy Wschodniej. Dlatego też antysystemowe przesłanie w polskiej muzyce rockowej zawsze było tak wyraźne - znacznie wyraźniejsze niż w innych krajach bloku socjalistycznego. Po drugie, do Polski Ludowej zapraszano artystów zachodnich, gdy w innych demoludach dopływ kultury Zachodu był bardzo ograniczony ${ }^{98}$. Ponadto w latach 90. Polska była trzecim najważniejszym ośrodkiem rozwoju muzyki reagge po Jamajce i Stanach Zjednoczonych ${ }^{99}$. Antypunkowa „,rewolucja” reagge zaczęła się w Trój2015 .

98 Grzegorz Brzozowicz, dziennikarz, w wywiadzie z autorką, Sheraton Hotel, Warszawa, 7 października

99 Tamże. 
mieście ${ }^{100}$. Ostatnim, lecz nie mniej ważnym wyróżnikiem polskiej sceny rockowej są bardzo wyraźne tendencje antyklerykalne, być może jedne z najwyraźniejszych na świecie.

\section{Bibliografia}

„Kraków Post”, 7 września 2015, http://www.krakowpost.com/9918/2015/09/the-cult-of-kukiz [dostęp: 10.10.2018].

„Newsweek” (edycja polska), nr 21/2016, http://www.newsweek.pl/plus/spoleczenstwo/bigcyc-i-krzysztof-skiba-wsparli-kod-dlaczego-,artykuly,385600,1,z.html [dostęp: 10.10.2018].

„The Guardian”, 24 września 2011, http://www.theguardian.com/commentisfree/belief/2011/ sep/24/sunday-satanist-voice-new-poland/print [dostęp: 10.10.2018].

„Wiener Zeitung”, 7 maja 2016, http://www.wienerzeitung.at/nachrichten/europa/europastaaten/817334_Wir-bleiben-in-Europa.html [dostęp: 30.10.2016].

Beats of Freedom Premieres in Poland, „Kraków Post” 12 marca 2010, http://www.krakowpost. com/article/1944 [dostęp: 10.10.2018].

Dee Snider's PMRC Senate Hearing Speech (Full), http://loudwire.com/twisted-sisters-dee-snider-1985-pmrc-senate-hearing/ [dostęp: 17.09.2018].

Frank Zappa at PMRC Senate Hearing on Rock Lyrics, https://www.youtube.com/watch?v=hgAF8Vu8G0w [dostęp: 17.09.2018].

Gnoiński L., Skaradzinski J., Encyklopedia polskiego rocka, Wydawnictwo In Rock, Konin 1996.

Kan A., Hayes N., Big Beat in Poland, [w:] S. Ramet (red.), Rocking the State: Rock Music and Politics in Eastern Europe and Russia, Westview Press, Boulder Colorado 1994.

Lastovsky A., Ideas and Practices of the Skinhead Youth Counterculture in Belarus, „Political Sphere" 2008, No. 11.

Marciniak M., Transnational Punk Communities in Poland: From Nihilism to Nothing Outside Punk, Lexington Books, Lanham 2015.

Pankowski R., The Populist Radical Right in Poland, Routledge, Abingdon-New York 2010.

Patton R., The Communist Culture Industry: The Music Business in 1980s Poland, „Journal of Contemporary History" 2012, Vol. 47, No. 2.

Pekacz J., On Some Dilemmas of Polish Post-Communist Rock Culture, „Popular Music” May 1992, Vol. 11, No. 2.

Polskie Radio, 19 sierpnia 2011, http://www.thenews.pl/1/9/Artykul/53634,Bibleripping-rock-star-cleared-in-court [dostęp: 10.10.2018].

Polskie Radio, 7 października 2011, http://www.thenews.pl/1/9/Artykul/56420,'Satanic'rocker-'heals'-wheelchairbound-guitarists [dostęp: 10.10.2018].

Polskie Radio, 14 października 2011, http://www.thenews.pl/1/9/Artykul/56807,Public-TVsacks-Satanic-rocker-from-talent-show [dostęp: 10.10.2018].

\footnotetext{
100 Jacek „Bodek” Bogdziewicz i Jarosław „Pastyl” Turbiarz, członkowie zespołu Golden Life, w wywiadzie z autorką, Sheraton Hotel, Sopot, 13 października 2015, Małgorzata Żurada, tłumaczka.
} 
Polskie Radio, 8 stycznia 2013, http://www.thenews.pl/1/9/Artykul/123543,Death-metal-starto-be-retried-for-insulting-religion [dostęp: 10.10.2018].

Polskie Radio, 2 lutego 2016, http:/www.thenews.pl/1/9/Artykul/239013,Politician-pollKukiz-ranked-as-Poles-preferred-drinking-partner [dostęp: 10.10.2018].

Rabiański R., Krakowska scena muzyczna. Encyklopedia, Musica Jagellionica, Kraków 2006.

Ramet S., Shake, Rattle, and Self-Management: Making the Scene in Yugoslavia, [w:] S. Ramet (red.), Rock Music and Politics in Eastern Europe and Russia, Westview Press, Boulder Colorado 1994.

Ramet S., Social Currents in Eastern Europe: The Sources and Consequences of the Great Transformation, Duke University Press, Durham 1995.

Ramet S., Zamascikov S., Bird R., The Soviet Rock Scene, [w:] S. Ramet (red.), Rocking the State: Rock Music and Politics in Eastern Europe and Russia, Westview Press, Boulder Colorado 1994.

Reuters, 7 maja 2016, http://www.reuters.com/article/us-poland-protest-idUSKCN0XY0EY [dostęp: 10.10.2018].

Ritter R., 1968' - the Emergence of a Protest Culture in the Popular Music of the Eastern Bloc?, [w:] B. Kutschke, B. Norton (red.), Music and Protest in 1968, Cambridge University Press, Cambridge 2013.

Slavorum, Polish rock and pop music, styczeń 2014, https://www.slavorum.org/forum/topic/ polish-rock-and-pop-music/ [dostęp: 10.10.2018].

The Nizkor Project, The Skinhead International: Poland, http://www.nizkor.org/hweb/orgs/ american/adl/skinhead-international/skins-poland.html [dostęp: 10.10.2018].

Voice of America, 12 lipca 2016, http://www.voanews.com/content/poland-clash-of-cultures-escalates/3415435.html [dostęp: 10.10.2018].

\section{Wywiady}

Azarewicz Krzysztof, autor tekstów grupy Behemoth, w wywiadzie z autorką, Sheraton Hotel, Sopot, 12 października 2015.

Bieniasz Andrzej „Pudel”, w wywiadzie telefonicznym z autorką z hotelu Ibis, Kraków, 16 października 2013.

Bogdziewicz Jacek „Bodek”, członek zespołu Golden Life, w wywiadzie z autorką, Sheraton Hotel, Sopot, 13 października 2015.

Bogdziewicz Jacek „Bodek”, członek zespołu Golden Life, w wywiadzie z autorką, Sheraton Hotel, Sopot, 13 października 2015.

Brzozowicz Grzegorz, dziennikarz, w wywiadzie z autorką, Sheraton Hotel, Warszawa, 7 października 2015.

Brzozowicz Grzegorz, dziennikarz, w wywiadzie z autorką, Sheraton Hotel, Warszawa, 7 października 2015 .

Chojnacki Krzysztof „Zygzak”, lider zespołu TZN Xenna, w wywiadzie z autorką, Sheraton Hotel, Warszawa, 6 października 2015.

Fruzińska Gosia, menedżerka i wokalistka w Rock Pubie, w wywiadzie z autorką, Novotel, Łódź, 21 października 2013. 
Gnoiński Leszek, reżyser i scenarzysta filmu Beats of Freedom - Zew Wolności oraz dziennikarz, w wywiadzie z autorką, Ibis Hotel, Kraków, 18 października 2013.

Kosmowski Ziemek, zespół Rendez-Vous, w wywiadzie z autorką, Novotel, Łódź, 21 października 2013.

Langer Ewa, członkini zespołu PRL (1992-1997), w wywiadzie z autorką, Ibis Hotel, Kraków, 19 października 2013.

Lipiński Tomek, założyciel grupy Tilt i współzałożyciel Brygady Kryzys, w wywiadzie z autorką, Sheraton Hotel, Warszawa, 5 października 2015.

Macias Sławek, dziennikarz Radia Łódź oraz muzyk, w wywiadzie z autorką, Novotel, Łódź, 21 października 2013.

Malejonek Dariusz „Maleo”, w wywiadzie z autorką, Sheraton Hotel, Warszawa, 10 października 2015.

Matera Robert, kompozytor, gitarzysta i wokalista Dezertera, w wywiadzie z autorką, Sheraton Hotel, Warszawa, 8 października 2015.

Michalak Marek, jazzman i kompozytor, w wywiadzie z autorką, Hard Rock Cafe, Kraków, 17 października 2013.

Praschil Piotr, producent płytowy, w wywiadzie z autorką w kawiarni w pobliżu sklepu muzycznego Music Corner w Krakowie, 18 października 2013.

Rozwadowski Paweł „Kelner”, niegdysiejszy członek zespołów Deuter i Izrael, w wywiadzie z autorką, Sheraton Hotel, Warszawa, 7 października 2015.

Rybacki Mikołaj i inni członkowie zespołu Percival, w wywiadzie z autorką, Sheraton Hotel, Warszawa, 9 października 2015.

Skiba Krzysztof, lider zespołu Big Cyc, w wywiadzie z autorką, Sheraton Hotel, Sopot, 14 października 2015.

Skiba Krzysztof, wywiad telefoniczny z autorką, 17 maja 2016.

Staszewski Kazik, założyciel i lider zespołu Kult, w wywiadzie z autorką przeprowadzonym w domu artysty, Warszawa, 5 października 2015.

Szubrycht Jarek, dziennikarz, w wywiadzie z autorką, Sheraton Hotel, Warszawa, 9 października 2015.

Turbiarz Jarosław „Pastyl”, członek zespołu Golden Life, w wywiadzie z autorką, Sheraton Hotel, Sopot, 13 października 2015.

Weiss Wiesław, redaktor magazynu „Teraz Rock”, w wywiadzie z autorką, Sheraton Hotel, Warszawa, 6 października 2015.

\section{Fonoteka}

Behemoth, Blow Your Trumpets Gabriel, http://www.lyricsfreak.com/b/behemoth/blow+your+trumpets+gabriel_21077142.html [dostęp: 10.10.2018].

Big Cyc, Antoni wzywa do broni, https:/www.youtube.com/watch?v=V3YxFizj6pk [dostęp: 10.10.2018].

Big Cyc, Makumba, https://www.youtube.com/watch?v=i4z3qo8VNfg [dostęp: 10.10.2018]. 
Brygada Kryzys, Nie ma nic, Tonpress 1982, https://www.youtube.com/watch?v=1cb7OpGvFN0 [dostęp: 10.10.2018].

Cool Kids of Death, Generacja nic, https:/www.youtube.com/watch?v=95zuqxSf9gg [dostęp: 10.10.2018].

Cool Kids of Death, Saint Etienne (Underworld mix), https://www.youtube.com/watch?v=OPwGINprMYM [dostęp: 10.10.2018].

De Mono, Meksyk/Oh yeah!, https://demono.pl/meksyk-oh-yeah.html [dostęp: 10.10.2018].

Kazik, Konsument (Kazik na Żywo), https://www.youtube.com/watch?v=WnNH3P809k0 [dostęp: 10.10.2018].

Maanam, Boskie Buenos (Buenos Aires), https://www.youtube.com/watch?v=bVaNvnPd-Dg [dostęp: 10.10.2018].

Maanam, Hamlet, https:/www.youtube.com/watch?v=9rD-f-rUcY4 [dostęp: 10.10.2018].

Maanam, Nocny Patrol, no. 6.25728-BL (Arctic 1983), https://www.youtube.com/watch? $\mathrm{v}=\mathrm{se}-$ NQ9gK2JBs [dostęp: 10.10.2018].

Myslovitz, Acidland, tekst w wersji polskiej na stronie http://www.tekstowo.pl/piosenka,myslovitz,acidland.html [dostęp: 10.10.2018].

Myslovitz, I'd like to die of love, https:/www.youtube.com/watch?v=7eh7EwijR04 [dostęp: 10.10.2018].

Post Regiment, http://www.last.fm/music/Post+Regiment [dostęp: 10.10.2018].

Püdelsi, Czerwone tango, https://www.youtube.com/watch?v=5r2OQqIhfog [dostęp: 10.10.2018].

Republika, Kombinat, https://www.youtube.com/watch?v=9kK6YyGQIQc\&list=PL8E0AD83E3948A0E6\&index=1 [dostęp: 10.10.2018].

Sweet Noise, Black Leather Boots, (z albumu Triptic 2007), http://artists.letssingit.com/sweetnoise-lyrics-black-leather-boots-1 tmqswc\#axzz3NrRK2E7z [dostęp: 10.10.2018].

Thompson, E, moj narode, HNZS Croatia Records 5475040 (2002).

Vader, Abandon all hope, https://www.youtube.com/watch? $\mathrm{v}=\mathrm{cNOtFaI3K}$ fo [dostęp: 10.10.2018].

Vader, Epitaph (for Humanity), https://www.youtube.com/watch?v=hDxNBWahqp0 [dostęp: 10.10.2018].

Vader,Morbid Reich, https://www.youtube.com/watch?v=q36G2IEizPk [dostęp: 10.10.2018].

Vader, Where angels weep, http://www.songlyrics.com/vader/where-angels-weep-lyrics/ [dostęp: 10.10.2018].

Zabranjeno pušenje, Dallas CD 139 (1997). 


\section{Streszczenie \\ Muzyka rockowa a polityka w Polsce: poetyka protestu i oporu w tekstach utworów rockowych}

Polska scena rockowa i punkowa służyła przez dziesięciolecia jako medium wyrażania antysystemowych wartości. W latach 80 . XX wieku, w czasie mrocznych dni stanu wojennego, grupy, takie jak Manaam, Perfect, TSA i Brygada Kryzys szydziły i satyrycznie traktowały władze komunistyczne; ostatnia z nich przestała grać w 1983 roku, po wprowadzeniu stanu wojennego, ale została reaktywowana w roku 1990. Od czasu ,wielkiego wybuchu” w 1989 roku zmienili się zarówno gracze związani z establishmentem, jak i natura opozycji rockowej. Zamiast komunizmu obecnie kapitalizm jest postrzegany jako główne wyzwanie przez niektóre zespoły rockowe i punkowe. Polska scena muzyczna jest zatem miejscem występowania różnorodnych perspektyw ideologicznych i muzycznych. Wszystkie odzwierciedlają dylematy współczesnego polskiego społeczeństwa z jego nierównościami, wyzwaniami tożsamościowymi i polaryzacją.

Słowa kluczowe: muzyka rockowa, muzyka alternatywna, Polska, transformacja

\section{Summary \\ Rock music and politics in Poland: The poetics of protest and resistance in the lyrics of rock songs}

The Polish rock and punk scene has served for decades as a medium for the expression of anti-establishment values. In the 1980s, during the dark days of martial law, groups such as Manaam, Perfect, TSA, and Brygada Kryzys variously mocked and satirised the communist authorities. Kryzys stopped playing in 1983 rather than work under the conditions of martial law, but was resurrected in 1990. Since the "big bang" of 1989, both the groups dominating the establishment and the nature of rock opposition have changed. Instead of communism, it is capitalism which is now seen by some rock and especially punk bands as "the enemy". The Polish music scene has witnessed a variety of perspectives. They all reflect the dilemmas of modern Polish society with its inequalities, identity threats and polarisation.

Keywords: rock music, alternative music, Poland, transformation 
Kamila Lasocińska (iD https://orcid.org/0000-0001-8336-5563 Akademia Humanistyczno-Ekonomiczna w Łodzi

\section{Kształtowanie twórczej codzienności. Warsztat autobiograficzny jako metoda wspomagania kreatywności dorosłych}

\section{Wstęp}

Niniejszy artykuł dotyczy możliwości wspomagania rozwoju twórczego osób dorosłych poprzez warsztat biograficzny i działania stymulujące twórcze myślenie w procesie rekonstruowania biografii. W związku z tym tematem odwołam się na początek do moich doświadczeń związanych z metodą biograficzną i refleksją autobiograficzną. Swoje pierwsze warsztaty biograficzne prowadziłam na Uniwersytecie Trzeciego Wieku w Akademii Humanistyczno-Ekonomicznej w latach 2008-2012. Postrzegałam wówczas zajęcia bazujące na materiale biograficznym jako formę pracy dydaktycznej zmierzającą do aktywizacji seniorów. Warsztaty te wymagały odniesienia się do doświadczeń życia, opierały się na osobistej refleksji nad wydarzeniami, a także nad samym sobą, możliwością twórczego spełniania się w życiu codziennym. Ukierunkowane były na planowanie własnej przyszłości. Metaforycznie ujmując temat, dotyczyły kreowania „twórczej codzienności”. Na jednych z zajęć słuchaczka zapytała mnie, dlaczego nie prowadzi się warsztatów biograficznych dla osób dorosłych na wcześniejszych etapach życia, kiedy szanse wprowadzenia znaczącej zmiany we własne życie są bardziej realne. To pytanie wpłynęło na moje podejście do wykorzystania metody biograficznej na zajęciach dydaktycznych i stanowiło bodziec, aby szukać możliwości jej zastosowania w pracy z uczestnikami z młodszych grup wiekowych, zakładając jednocześnie, że jest to metoda wspomagająca rozwój i uczenie się dorosłych. Zaczęłam postrzegać warsztat biograficzny jako możliwość rozwoju twórczego, kształtowania siebie i autokreacji. Podjęłam 
się zaprojektowania takich ćwiczeń i zadań, które łączą metodykę pracy biograficznej z zasadami dydaktyki twórczości ${ }^{1}$.

W moim artykule pokazuję możliwości wspomagania kreatywności osób dorosłych poprzez warsztat autobiograficzny i zadania odwołujące się do refleksji nad doświadczeniami życia (zadania biograficzne). Poruszam obszar dydaktyki biograficznej i uczenia się w oparciu o własne doświadczenia życiowe. Przedstawiam zarówno założenia teoretyczne, jak i propozycję struktury działań praktycznych mających na celu stymulowanie myślenia twórczego osób dorosłych. Interesują mnie takie formy aktywności edukacyjnych bazujące na opowieści o życiu, które wspomagają możliwości autokreacji, transgresji i kreatywności osoby na różnych etapach życia dorosłego. Celem artykułu jest refleksja nad tym, jak można stymulować rozwój osobisty dorosłych poprzez świadome i twórcze odnoszenie się do doświadczeń życia w kontekście przeszłości, teraźniejszości i przyszłości. Nawiązuję do koncepcji takich zajęć, które wspomagają refleksję autobiograficzną oraz twórcze podejście do życia, zdarzeń i doświadczeń codziennych. Uznaję, że propozycja warsztatów autobiograficznych zawierających także zadania inspirujące do działań twórczych wpisuje się w potrzeby i cele stymulowania rozwoju osób dorosłych na różnych etapach życia².

\section{Współczesne potrzeby rozwojowe w perspektywie przemian społecznych a uczenie się biograficzne}

Omawiając perspektywy rozwoju osób dorosłych w kontekście wspomagania ich kreatywności i postaw twórczych, należy uwzględnić warunki społeczne określające możliwości i potrzeby kształtowania swojego życia przez osobę, a także świadomego kształtowania siebie na etapie dorosłości. Analizy rzeczywistości społecznej podkreślają nasilanie się zjawisk zakłócających stabilizację życiową, przewidywalność, trudności tworzenia planów na przyszłość i potrzebę uwzględniania ich modyfikacji. Tempo zmian następuje bowiem tak szybko, że nie możemy przewidzieć skutków i następstw własnego działania $^{3}$. Dotyczy to obszaru działań zawodowych, przemian życia rodzinnego, rozwoju mediów i nowych technologii, ale także innych sfer $^{4}$. W związku z tym wyróżniającą się cechą współczesnych biografii staje się ich zróżnicowanie, barwność, zmienność, ale także związana z tym konieczność samookreślania i szukania własnej drogi życia. Badacze rzeczywistości społecznej podkreślają pojawiającą się różnorodność możliwości życia w obrębie różnych faz życiowych, niejednolitość pojedynczych biografii. Dodatkowo wzrasta zjawisko indywidualnego myślenia o sukcesie, życiu rodzinnym czy pracy

${ }^{1}$ K. Lasocińska, Życie na opak - scenariusze zajęć autobiograficznych, [w:] K. Lasocińska, J.K. Wawrzyniak, Autobiografia jako twórcze wyzwanie. Scenariusze warsztatów biograficznych, Wydawnictwo Akademickie Żak, Warszawa 2013.

${ }^{2}$ K. Lasocińska, Transgresje jako aspekt wzbogacania aktywności twórczej i uczenia się w oparciu o doświadczenia biograficzne, [w:] A. Ciążela, S. Jaronowska (red.), Transgresja jako motyw refleksji nad wychowaniem, Wydawnictwo Akademii Pedagogiki Specjalnej, Warszawa 2017.

3 Z. Bauman, Plynne czasy. Życie w epoce niepewności, Wydawnictwo Sic!, Warszawa 2007, s. 108-118.

4 A. Giddens, Życie w spoleczeństwie posttradycyjnym, [w:] U. Beck, A. Giddens, S. Lash, Modernizacja refleksyjna, PWN, Warszawa 2009, s. 79-140. 
zawodowej. W zmieniającym się świecie musimy regularnie konstruować potencjalne wersje przyszłości, nie mając jednocześnie gwarancji ich urzeczywistnienia ${ }^{5}$. Anthony Giddens podkreśla, że tempo zmian jest szybsze niż kiedykolwiek wcześniej, a zachodzące przemiany wykraczają poza oczekiwania człowieka i często wymykają się jego kontroli ${ }^{6}$. Ponadto istotnym faktem biograficznym staje się biologiczne wydłużanie się życia ludzkiego, które powoduje przesunięcie i poszerzenie niektórych faz życia. Pojawia się coraz więcej obszarów do zagospodarowania, a spełnianie niektórych ról jest tylko czasowe, na przykład dotyczy to roli rodzica. Wydłużają się okresy życia, kiedy ludzie nie koncentrują się na swoich tradycyjnych rolach, zakładające potrzebę ponownego samookreślania, podejmowania nowych wyzwań i zadań życiowych ${ }^{7}$. Zdaniem Giddensa istotne staje się kształtowanie własnego stylu życia, ponieważ zmiany biograficzne wymagają odchodzenia od stałych wzorów wyznaczających strukturę planów i projektów życiowych. Porządki zadań rozwojowych dotyczące okresu dorosłości wskazywane w niektórych koncepcjach rozwoju ${ }^{8}$ mogą się zmieniać, ulegać przesunięciom czasowym, przykładem jest coraz późniejszy wiek zamążpójścia, decyzji o rodzicielstwie, ale także możliwe są różne modyfikacje życia osobistego, rodzinnego wynikające z emigracji zarobkowej, niepewności rynku pracy i innych czynników wpływających na przemiany życia. „Otwarty” charakter tego, co ma nadejść, wymaga od człowieka zdolności kształtowania swojego bytu ${ }^{9}$, jednocześnie konfrontuje się on z nowymi wyzwaniami na różnych etapach życia.

Przemiany, jakie zachodzą w społeczeństwie i kulturze, ukazują, że człowiek dorosły musi niejako sam określić kierunek własnego rozwoju, może zatem działać według określonych wzorców albo w zamierzony sposób je przekraczać bądź indywidualnie interpretować. Proces ten wymaga rozwijania pewnych kompetencji biograficznych pozwalających na intencjonalne kształtowanie swojego życia i siebie samego na różnych etapach dorosłości.

\section{Kompetencje biograficzne a stawanie się twórcą własnej biografii}

Nieprzewidywalne wydarzenia i przemiany zachodzące w świecie wymagają otwarcia się jednostki na procesy wewnętrznego doświadczenia, akceptacji nowych okoliczności życiowych, poszukiwania nowych rozwiązań. Jeśli założymy, że człowiek w sytuacji zachodzących przemian społecznych może stawać się w pewien sposób twórcą własnego

5 U. Beck, A. Giddens, S. Lash, Przedmowa, [w:] tychże, Modernizacja refleksyjna, PWN, Warszawa 2009, s. 9.

${ }^{6}$ A. Giddens, Nowoczesność i tożsamość. „Ja” i społeczeństwo w epoce późnej nowoczesności, PWN, Warszawa 2001, s. 40.

7 U. Beck, Społeczeństwo ryzyka. W drodze do innej nowoczesności, Wydawnictwo Naukowe „Scholar”, Warszawa 2002, s. 170.

8 R.J. Havighurst, Developmental Tasks and Education, Longman, Nowy Jork-Londyn 1981; D.J. Levinson, A conception of adult development, „American Psychologist” 1986, No. 41; D.J. Levinson, The mid-life transition: A period in adult psychosocial development, „Psychiatry” 1977, No. 40.

9 A. Giddens, Nowoczesność..., dz. cyt. 
życia bądź że istnieją coraz większe możliwości, aby się nim stawał, warto zwrócić uwagę na rolę doświadczenia w rozwoju człowieka dorosłego i możliwości świadomego kształtowania siebie i swojego życia, a także wspomagania rozwoju osoby dorosłej poprzez zadania z zakresu dydaktyki biograficznej. Tym samym podkreślam potrzebę zdobywania przez osoby dorosłe takich kompetencji biograficznych, które pozwolą im dokonywać ważnych wyborów życiowych, określać kierunki ich rozwoju niezależne od różnego rodzaju oczekiwań i tendencji społecznych. Znaczenie dla kształtowania osoby i jej życia mają coraz bardziej działania pozwalające na konstruowanie nowej perspektywy biografii, podnoszenie jakości własnego życia, nabywanie trwałych umiejętności i kompetencji ${ }^{10}$. Wartością staje się zdobywanie takich kompetencji biograficznych, które umożliwiają osobie odnajdywanie się w zmieniającym się świecie ${ }^{11}$. Jednocześnie współczesny człowiek często ma trudności, aby się odnaleźć w złożoności świata, w którym żyje, nie jest przygotowany do radzenia sobie ze zmianami życia, nie jest w stanie przewidzieć jego biegu ani sytuacji, z którymi przyjdzie mu się zmierzyć. Pojawiają się zatem nowe wyzwania dla pedagogiki, które przede wszystkim dotyczą przygotowania jednostki do poszukiwania innych niż dotychczas możliwości rozwoju w okresie całego życia ${ }^{12}$. Ujawnia to potrzebę rozwijania takich kompetencji biograficznych, które pozwolą osobie określić swój rozwój i jego kierunki w różnych okolicznościach życiowych. Do nich należą kompetencje biograficzne związane z:

1. Refleksyjnością i autorefleksją - wraz ze świadomością wyboru pojawia się zapotrzebowanie na refleksyjność, rozumianą jako umiejętność analizy własnego doświadczenia, zdolność generowania wiedzy o sobie i otaczającym świecie ${ }^{13}$, gdyż, życie pozbawione refleksji jest tylko życiem, natomiast życie w świecie idei, wartości i wiedzy jest biografią"14.

2. Podejmowaniem analizy przeszłości służącej rozumieniu przyszłości - coraz szybsze tempo życia ukierunkowuje człowieka na przyszłość, dlatego istotnego znaczenia nabiera pojęcie antycypacji i umiejętność prognozowania przyszłości, tworzenia możliwych jej scenariuszy. Dokonanie podsumowań czy bilansu dotychczasowego życia pozwala na refleksyjne projektowanie wizji własnej przyszłości i zmianę wcześniejszych nastawień. Znaczenia nabiera rozwijanie wyobraźni biograficznej związanej z umiejętnością odnoszenia się do różnych kategorii czasowych i wydarzeń. Przypuszcza się bowiem, że odwoływanie się do przeszłości uruchamia zdolność wyobrażania sobie przyszłych doświadczeń i służy konstruowaniu strategii działania w przyszłości: planowania, projektowania, realizacji celów ${ }^{15}$.

${ }^{10}$ M. Przetacznik-Gierowska, M. Tyszkowa, Psychologia rozwoju człowieka, Wydawnictwo Naukowe PWN, Warszawa 2000.

11 U. Beck, Społeczeństwo..., dz. cyt.

12 B. Bugajska, C. Timoszczyk-Tomczak, Podróż w czasie. Warsztat rozwoju osobistego osób starszych, Wydawnictwo Naukowe Uniwersytetu Szczecińskiego, Szczecin 2014, s. 8.

13 A. Giddens, Nowoczesność..., dz. cyt.

14 D. Lalak, Życie jako biografia. Podejście biograficzne w perspektywie pedagogicznej, Wydawnictwo Akademickie Żak, Warszawa 2010, s. 39.

15 B. Bugajska, C. Timoszczyk-Tomczak, dz. cyt. 
3. Samookreśleniem i samorozumieniem - łączącymi się ze zdobywaniem wiedzy o sobie samym poprzez analizę różnych doświadczeń życia, tworzenie opowieści o sobie i swoim życiu, dzielenie się własną historią z innymi. Konfrontacja różnych opowieści o życiu i wymiana doświadczeń pozwala zrozumieć siebie, określić kim się jest.

4. Twórczością i kreatywnością - rozumianymi jako „indywidualne wycieczki w nieznane oparte na zaufaniu we własne siły"16. Kreatywność łączy się z umiejętnością odnajdywania się w sytuacjach nowych, niedookreślonych, niepewnych i naznaczonych ryzykiem. Związana jest z otwartością na nowe sytuacje, z umiejętnością przełamywania schematów, odnajdywaniem nowych rozwiązań problemów, różnych znaczeń, interpretacji, a także z autokreacją, transgresją, czyli przekraczaniem siebie, własnych granic i barier. Jedną z możliwości współczesnego życia jest „uwalnianie się” oznaczające, że człowiek ma szansę szukać samego siebie. Może decydować o wyborze własnej drogi życia i strategii działania, ma coraz więcej możliwości, aby na różnych etapach rozwoju zmieniać siebie i swoje życie ${ }^{17}$.

5. Podstawowym zaufaniem - rozumianym przez Giddensa jako wewnętrznie zgeneralizowane poczucie bezpieczeństwa, wiara w otoczenie społeczne, a jednocześnie zdolność ufania samemu sobie, co pozwala na podejmowanie swobodnych decyzji o wchodzeniu w sytuacje ryzykowne i niepewne z przekonaniem o możliwości poradzenia sobie z nimi ${ }^{18}$. Giddens stwierdza również, że podstawowe zaufanie zakłada świadomość potencjalnej straty, pozwala na przyjmowanie odstępstw od norm i reguł, bo nie są one traktowane jako potencjalne zagrożenia. Osiąganie poczucia bezpieczeństwa (ontologicznego) opiera się na zaufaniu we własne siły i kreatywność ${ }^{19}$.

Opisane kompetencje biograficzne wskazują na znaczenie i cele edukacji biograficznej, traktującej doświadczenie życiowe człowieka jako ważny aspekt uczenia się i refleksji stymulującej rozwój osób dorosłych w życiu codziennym. W związku z tym szczególnego znaczenia nabiera edukacja odwołująca się do możliwości twórczych człowieka, a także doświadczeń autobiograficznych. Warto zatem wskazać, jak można wspierać twórcze myślenie dorosłych przez pracę z własną biografią.

16 A. Giddens, Nowoczesność..., dz. cyt.

17 Z. Pietrasiński, Ekspansja pięknych umysłów. Nowy renesans i ożywcza autokreacja, Wydawnictwo CiS, Warszawa 2008; K. Lasocińska, Życie na opak..., dz. cyt.; K. Lasocińska, Twórcze aspekty działań biograficznych, [w:] K. Lasocińska, J.K. Wawrzyniak, Autobiografia jako twórcze wyzwanie. Scenariusze warsztatów biograficznych, Wydawnictwo Akademickie Żak, Warszawa 2013; K. Lasocińska, Autobiografia jako autokreacja. Twórcze aspekty procesu myślenia autobiograficznego w edukacji dorosłych, [w:] E. Dubas, J. Stelmaszczyk (red.), Biografia i badanie biografii: biografie edukacyjne. Wybrane konteksty, t. 3, Wydawnictwo Uniwersytetu Łódzkiego, Łódź 2014; K. Lasocińska, Kryzys połowy życia-zdobywanie kompetencji autokreacyjnej i dążenie do mądrości, [w:] E. Dubas, J. Stelmaszczyk (red.), Biografie edukacyjne-wybrane konteksty, Wydawnictwo Uniwersytetu Łódzkiego, Łódź 2014.

18 A. Giddens, Nowoczesność..., dz. cyt., s. 139.

19 Tamże, s. 29. 


\section{Kreatywność, transgresje, autokreacja jako przejaw aktywności twórczej dorosłych}

W podejmowanych dotychczas i planowanych przeze mnie badaniach naukowych i projektach dydaktycznych dotyczących metody biograficznej interesuje mnie szczególnie problematyka zmiany, rozwoju i autokreacji na przestrzeni życia, z uwzględnieniem aktywności dorosłych, czyli osób w pewien sposób już ukształtowanych, mających często za sobą podstawowe wybory dotyczące pracy, rodziny, samych siebie i swojego życia ${ }^{20}$. Zakładam, że twórcza aktywność dorosłych podejmowana w odpowiedzi na stawiane im zadania biograficzne może ujawniać się, jeśli zadania te uwzględniają możliwość kreatywności, autokreacji i transgresji twórczych. Wymienione pojęcia pomagają wyjaśnić, jak możemy stymulować działania twórcze osób dorosłych i zachęcać je do intencjonalnego kształtowania siebie i swojego życia. Warto zatem przybliżyć i zdefiniować, jaką rolę i znaczenie będą mieć aktywności autobiograficzne obejmujące poszerzanie kreatywności, wspomagające autokreację i uwzględniające działania o charakterze transgresyjnym.

Kreatywność zdaniem profesor Ireny Pufal-Struzik stanowi kompleks właściwości podmiotu sprzyjających samodzielnemu formułowaniu problemów, generowaniu oryginalnych idei i niestereotypowych rozwiązań, które podmiot potrafi właściwie wykorzystać w różnych okolicznościach i czasie ${ }^{21}$. Według Wiesławy Limont kreatywność odnosi się do wewnętrznej aktywności podmiotu, łączy się ze sferą rozwojową - mogą być to na przykład pomysły na rozwiązanie sytuacji krytycznej, na zmianę działania, modyfikację stylu życia ${ }^{22}$. Z kolei Anthony Giddens rozumie kreatywność jako zdolność do działania w sposób nowy względem ustanowionych wzorów. Oznacza to podejmowanie ryzyka, odkrywanie drogi do autentyczności, odnajdywanie ,ja autentycznego zamiast ja fałszywego"23. Odwołując się do przywołanych definicji, wyznacznikiem kreatywności w aspekcie dydaktyki biograficznej będzie zdolność i otwartość osoby związana z generowaniem nowych rozwiązań dla problemów, ale także pomysłów na własne życie. To inaczej gotowość do przekształcenia własnego działania wobec zmieniających się warunków życia, odchodzenia od własnych i społecznych schematów, ale także podejmowanie działań niestandardowych, nietypowych, oryginalnych względem tego, co dotychczas osoba realizowała lub wobec tego, co jest na danym etapie życia oczekiwane przez innych. Kreatywność może być również istotna w kontekście gotowości osoby do zmiany interpretacji historii biograficznej, odwrócenia perspektywy postrzegania własnej sytuacji życiowej. Kreatywność w aspekcie biograficznym pozwala wskazać różne możliwe kierunki dalszego rozwoju oraz interpretacje trudnych i złożonych momentów życia.

${ }^{20}$ K. Lasocińska, Życie na opak..., dz. cyt.; K. Lasocińska, Życie poza schematem. Analiza biografii twórców, Wydawnictwo Akademii Humanistyczno-Ekonomicznej w Łodzi, Łódź 2011; K. Lasocińska, Twórcze..., dz. cyt.

${ }^{21}$ I. Pufal-Struzik, Podmiotowe i społeczne warunki twórczej aktywności artystów, Wszechnica Świętokrzyska, Kielce 2006.

${ }^{22}$ W. Limont, Twórczość w aspekcie cyklu życia, [w:] E. Dombrowska, A. Niedźwiecka (oprac.), Twórczość - wyzwanie XXI wieku, Oficyna Wydawnicza „Impuls”, Kraków 2003, s. 18.

23 A. Giddens, Nowoczesność..., dz. cyt., s. 109. 
Kolejne pojęcie ujawniające znaczenie twórczości w odniesieniu do biografii osoby dorosłej to autokreacja, która przekłada się bezpośrednio na kształtowanie siebie i swojego życia ${ }^{24}$. Autokreacja jest rozumiana jako ukierunkowane działanie mające na celu planowaną zmianę siebie i własnych działań ${ }^{25}$. Łączy się z decyzją osoby, w jakim kierunku chce podążać, jak ma wyglądać jej życie, jakie zmiany chce wprowadzić. Obejmuje szeroki obszar doświadczeń i aktywności codziennych i przede wszystkim łączy się z refleksyjnym podejściem do życia, ogólnie ze zdolnością do refleksji nad biografią. Refleksja ta nie dotyczy tylko teraźniejszości i przyszłości osoby, ale zakłada odniesienie się do przeszłości, która jest istotnym źródłem wiedzy o sobie. Ważnymi pojęciami związanymi z autokreacją są: autorefleksja, autodystans i bilansowanie ${ }^{26}$. Potrzeba autokreacji ujawnia się bezpośrednio w tworzonych przez osobę projektach i zadaniach dotyczących własnego życia, w planowaniu przyszłości, stawianych sobie celach i wyzwaniach. Autokreacja wymaga również refleksyjnego odniesienia się do realizowanych projektów i zadań w przeszłości, dokonania pewnego podsumowania i bilansu, który pozwala na określenie ich sensu, znaczenia i wartości. Autokreacja w kontekście działań biograficznych może wyrażać się w gotowości do przekształcania i transformacji własnej historii życia, odnosi się do gotowości osoby, aby stworzyć zróżnicowany obraz własnego życia. Dotyczy zatem refleksyjności ujawniającej się w procesie przekształcania własnej historii życia, poszukiwania nowych inspiracji do refleksji nad zdarzeniami. W kontekście teraźniejszości i przyszłości będzie dotyczyć ponownego samookreślenia, gotowości zmiany ukierunkowanej na własną osobę, budowania i realizacji planów i zamierzeń życiowych.

Ostatnie pojęcie, które uznaję za szczególnie ważne dla zrozumienia twórczego charakteru warsztatów autobiograficznych i aktywności związanej z biografią, to transgresja, która wiąże się przede wszystkim z gotowością osoby do przekraczania własnych granic, pokonywaniem własnych barier, trudności i ograniczeń. Pojęcie transgresji łączy się również z rozwojem i zmianą, doskonaleniem, to dzięki działaniom transgresyjnym człowiek stara się przekształcić rzeczywistość, wychodzi poza to, kim jest i co posiada ${ }^{27}$. W tym aspekcie interesuje mnie zwłaszcza znaczenie transgresji twórczych, które Józef Kozielecki określa jako takie działania, których celem jest poszerzenie granic poznania, rozwój kultury, rozbudowanie światopoglądu ${ }^{28}$. Transgresje o charakterze twórczym są istotne, bo wzbogacają całe życie człowieka, są szczególnie ważne w sytuacjach nowych, przełomowych i nieznanych. Trudne sytuacje, przełomy biograficzne, doświadczenia krytyczne mogą być dla osoby szansą, wyzwaniem, bodźcem do rozwoju, do podjęcia nowych aktywności. Ważna jest jednak reakcja na trudność, pozytywne przejście kryzysu, wyjście poza nawyki, przyzwyczajenia, lęki. Oduczanie się starych poglądów i przyzwyczajeń,

${ }^{24}$ Z. Pietrasiński, Ekspansja ..., dz. cyt., s. 163.

${ }^{25}$ Zob. K. Lasocińska, Autobiografia..., dz. cyt.

${ }^{26}$ Z. Pietrasiński, Ekspansja ..., dz. cyt., s. 137-165; K. Lasocińska, Rozwijanie i wspomaganie kompetencji biograficznych na Uniwersytecie Trzeciego Wieku w Akademii Humanistyczno-Ekonomicznej w Łodzi, [w:] E. Woźnicka, Ł. Zaorski-Sikora (red.), Akademia - idee, metody, działania, Wydawnictwo Akademii Humanistyczno-Ekonomicznej w Łodzi, Łódź 2013.

27 J. Kozielecki, Psychotransgresjonizm. Nowy kierunek w psychologii, Wydawnictwo Akademickie Żak, Warszawa 2001, s. 43-44.

${ }^{28}$ Tamże. 
przezwyciężanie stereotypów w myśleniu jest ważnym elementem uczenia się w okresie dorosłości - proces ten jest czasem trudniejszy niż kształtowanie nowych zachowań. Człowiek dorosły doskonali się zdaniem Pietrasińskiego w przekraczaniu ograniczeń wyniesionych z poprzednich faz życia ${ }^{29}$. Aspekty działań transgresyjnych mają duże znaczenie w odniesieniu do możliwości, jakie stwarza warsztat autobiograficzny i zadania biograficzne. Kontekst transgresji ujawnia się w gotowości osoby do podejmowania ryzyka, przekraczania swoich ograniczeń w celu tworzenia nowych jakości, ale także jej otwartości do porzucania pewnych nawyków, przyzwyczajeń narzucających pewne oczywiste sposoby działania i rozwiązywania problemów. Pojęcie transgresji jest również istotne w kontekście przemian własnej opowieści o życiu, będzie łączyć się z gotowością do łamania schematów interpretacyjnych, przekraczania siebie w sposobie patrzenia na własne życie. Transgresja ujawnia się jako motyw działań wychodzących poza konwencjonalne uwarunkowania, utrudniające autentyczny rozwój. Aktywności transgresyjne odgrywają ponadto ważną rolę w przezwyciężaniu własnych niepokojów i kryzysów, wtedy, kiedy osoba przekracza swoje wewnętrzne ograniczenia i bariery.

Działania sprzyjające indywidualnej kreatywności, a także ujawniające przestrzeń dla autokreacji i transgresji twórczych zawierają się w takich zadaniach biograficznych, które stymulują:

- zmianę obrazu własnego ,ja”, stosunku do własnej osoby i własnych możliwości,

- transgresyjne doświadczenie czasu - odniesienie się osoby do własnej przeszłości, teraźniejszości oraz kreowanie wizji własnej przyszłości,

- zmianę perspektywy własnej biografii poprzez transformacje opowieści o życiu, wykorzystanie fantazji i fikcji biograficznej, zastosowanie metafory biograficznej,

- stawianie sobie konkretnych zadań do realizacji celów życiowych, tworzenie projektów służących osobistemu rozwojowi,

- różne sposoby konstruowania wypowiedzi autobiograficznej i formy autoekspresji ${ }^{30}$.

Przejawem aktywności twórczej osób dorosłych w działaniu autobiograficznym będzie zatem odniesienie się w realizowanych zadaniach i projektach związanych z własną opowieścią o życiu do obszaru kreatywności, autokreacji i transgresji twórczych. Pojęcia te wzajemnie uzupełniają myślenie o twórczości dorosłych w kontekście całożyciowego rozwoju i uczenia się uwzględniającego wiedzę tworzoną na bazie własnych doświadczeń życia. Istotne jest wskazanie możliwości, jakie stwarza warsztat autobiograficzny w edukacji dorosłych, jakie może mieć zastosowanie i formę, a także w jaki sposób może służyć kształtowaniu siebie, własnego życia, „twórczej codzienności”.

${ }^{29}$ Z. Pietrasiński, Rozwój człowieka dorosłego, „Wiedza Powszechna”, Warszawa 1990, s. 46; K. Lasocińska, Kryzys..., dz. cyt.

${ }^{30}$ Zob. K. Lasocińska, Transgresje..., dz. cyt., s. 182-188. 


\section{Warsztat autobiograficzny jako warsztat służący "twórczej codzienności”}

Człowiek może być w roli twórcy zmian w swoim życiu, gdy ma możliwość wprowadzania transformacji w swoje życie, jest wówczas inicjatorem, wykonawcą ${ }^{31}$, autorem przemian zamierzonych, kontrolowanych i świadomych. Może sam ingerować w zdarzenia życia, modyfikować ich bieg, decydować o własnej przyszłości, tworzyć wizje życia, a także różnorodnie interpretować zdarzenia życiowe. Zakładam, że bycie twórcą zmian w swoim życiu wymaga twórczej postawy osoby wobec własnego życia, zdarzeń i doświadczeń życiowych. Uznaję również, że świadome i zamierzone kształtowanie własnego życia wymaga kreatywności pozwalającej wprowadzać we własne działania aspekty nowatorstwa, innowacyjności, zmiany. Ponadto zakłada ważną rolę autokreacji związanej z refleksyjnym podejściem do kolejnych etapów życia i szczególnie użytecznej w zmieniających się warunkach życia, a także transgresji wyrażającej się w gotowości osoby do wychodzenia poza własne ograniczenia, schematy i nawyki.

W jaki sposób zatem możemy stymulować rozwój twórczy na etapie życia dorosłego, jak należy inspirować dorosłych do działań autokreacyjnych, transgresji twórczych i kreatywności w działaniach codziennych? Uznaję, że potrzeba refleksyjnego i świadomego rozwoju dorosłych ujawnia szczególną rolę i znaczenie warsztatu autobiograficznego, w ramach którego wykorzystuje się doświadczenia życiowe jako inspirację i ważny obszar aktywności twórczej uczestników. Warto również określić, jakie cele spełnia aktywność ukierunkowana na pracę z własną biografią. Według Pierre’a Dominicé istotne znaczenie ma zajmowanie się własnymi historiami życia i dzielenie się nimi w grupie innych osób. Takie działania dają możliwość refleksji nad doświadczeniami związanymi z uczeniem $\operatorname{się}^{32}$. Zdaniem autora cały proces życia to proces formacyjny, edukujący, samo życie jest edukacją, bowiem przekształca nas i kształtuje ${ }^{33}$. Istotną rolę w uczeniu się z życia odgrywa proces porządkowania dotychczasowych doświadczeń, społeczny charakter tego działania - przekazanie doświadczeń innym ludziom i wysłuchanie ich narracji ${ }^{34}$.

Przedstawione założenia teoretyczne ujawniają ważną rolę warsztatów i zadań autobiograficznych. Zdaniem profesor Olgi Czerniawskiej warsztaty te są jedną z form dydaktyki aktywizującej, twórczej, kreatywnej, odgrywają istotną rolę w analizie przeżyć i doświadczeń. Natomiast same doświadczenia życiowe mogą stać się szczególnie wartościowe, jeśli zostaną poddane analizie i refleksji. Samo nieprzetworzone doświadczenie nie zmienia człowieka, gdyż nie ma on dostępu do wiedzy, którą może z niego czerpać. Doświadczenia życiowe wymagają zatem przemyślenia, przetworzenia, reinterpretacji,

31 M. Kuleta, Człowiekjako kreator zmian w swoim życiu, [w:] D. Kubacka-Jasiecka (red.), Człowiek wobec zmiany. Rozważania psychologiczne, Wydawnictwo Uniwersytetu Jagiellońskiego, Kraków 2002, s. 21-39.

32 P. Dominicé, Uczyć się z życia. Biografia edukacyjna w edukacji dorostych, WSHE, Łódź 2006, s. 11.

33 O. Czerniawska, Drogi edukacyjne i ich meandry, [w:] E. Dubas, O. Czerniawska (red.), Drogi edukacyjne i ich biograficzny wymiar, Biblioteka Edukacji Dorosłych, Warszawa 2002, s. 30.

34 P. Dominicé, dz. cyt., s. 11. 
przewartościowania $^{35}$. Zasadniczą funkcję w tym procesie pełni odniesienie się do własnej przeszłości, ale także do doświadczeń życia przeżywanego w aktualnym jego momencie. W tym ujęciu warsztaty autobiograficzne stanowią pewnego rodzaju trening uważności, pogłębiający świadomość odczuwania siebie „tu i teraz”, uczą otwartości i akceptacji tego, co przynosi życie. Bardzo ważne jest również ukierunkowanie na przyszłość i aktywne jej projektowanie, poszukiwanie najbardziej optymalnych strategii realizacji celów ${ }^{36}$, podnoszenia jakości życia ${ }^{37}$.

Celem warsztatu autobiograficznego jest zatem skłonienie jednostki do określenia programu własnego życia w trzech płaszczyznach czasu: przeszłości, teraźniejszości i przyszłości. Ponadto warsztat służy analizie historii autobiograficznej, która łączy się z dążeniem do poczucia integralności, równowagi i harmonii. Warsztat autobiograficzny może zawierać elementy warsztatu twórczości i wspomagać potrzebę własnego rozwoju i autokreacji wśród osób dorosłych ${ }^{38}$. Zakładam również, że podejmowana świadomie aktywność autobiograficzna pozwala na pełniejsze przeżywanie tego, co niesie codzienne życie. Pomaga osobie dorosłej brać odpowiedzialność za własne życie i wykorzystywać swój potencjał twórczy w codziennych działaniach.

\section{Struktura i porządek działań biograficznych służących aktywności twórczej w życiu codziennym}

Podstawowym elementem warsztatu autobiograficznego są zadania biograficzne, które wymagają od uczestnika refleksyjnego odniesienia się do własnych doświadczeń życiowych (przeszłość), podjęcia refleksji dotyczącej chwili obecnej (teraźniejszość), a także odniesienia się do planów i projektów (przyszłość) ${ }^{39}$. Zadania biograficzne mają na celu wywołanie myślenia twórczego o własnej biografii i zachęcenie uczestników do dokonania modyfikacji w obszarze wybranej interpretacji historii życia, przekroczenia własnych schematów myślenia o życiu i pokonania sztywnych przekonań. Realizacja zadań biograficznych może być także strategią badawczą, która umożliwia analizę postaw twórczych dorosłych w badaniach biograficznych. Znaczenie ma zarówno sama treść odtwarzanej przez osobę historii biograficznej, jak i aktywność respondentów w procesie badania, ich stopień otwartości, gotowości i elastyczności w dokonywaniu przekształceń, reinterpretacji biografii, przekraczania przyjętego schematu biograficznego.

Poza dłużej trwającym i wymagającym szczególnej organizacji warsztatem autobiograficznym znaczenie mają w edukacji dorosłych odniesienia biograficzne, które mogą być obecne w różnych kontekstach edukacyjnych poprzez to, że włączają aspekty refleksji biograficznej uczących się w treści różnych działań związanych z uczeniem się. Edukacja

35 O. Czerniawska, Przedmowa, [w:] K. Lasocińska, J.K. Wawrzyniak, Autobiografia jako twórcze wyzwanie. Scenariusze warsztatów biograficznych, Wydawnictwo Akademickie Żak, Warszawa 2013, s. 9-10.

36 B. Bugajska, C. Timoszczyk-Tomczak, dz. cyt., s. 8-9.

${ }^{37}$ K. Lasocińska, Transgresje..., dz. cyt.

${ }^{38}$ K. Lasocińska, J.K. Wawrzyniak, Autobiografia jako twórcze wyzwanie. Scenariusze warsztatów biograficznych, Wydawnictwo Akademickie Żak, Warszawa 2013.

${ }^{39}$ K. Lasocińska, Życie na opak..., dz. cyt.; K. Lasocińska, Transgresje..., dz. cyt. 
biograficzna nie ogranicza się zatem tylko do organizowania specjalnie wyodrębnionych zajęć warsztatowych dla wybranej grupy uczestników, ale może być obecna na różnego rodzaju kursach, szkoleniach, zajęciach dydaktycznych dla dorosłych, które nie są bezpośrednio dedykowane analizie biografii, ale zawierają elementy refleksji biograficznej, wplatane w ogólne treści wybranych zajęć. Odniesienia biograficzne mogą być krótkie, stanowić bodziec wspomagający uczenie się i motywowanie uczących w procesie dydaktycznym $^{40}$.

Zadania i odniesienia biograficzne można ukierunkować na aktywność uczących się mającą na celu stworzenie pewnej struktury porządkującej doświadczenia życia, a zatem akcentuje się wówczas obszar „stałości”. Natomiast uzupełnienie i pogłębienie tych działań stanowią takie zadania, które umożliwiają osobie zajmującej się własną biografią reinterpretację i restrukturyzację historii życia, prowokują ją do poszukiwania nowych znaczeń, kierunków myślenia o biografii, zdarzeniach życia, swojej roli w tych zdarzeniach. Należą zatem do obszaru „zmiany”.

W związku z tymi podziałami aktywności autobiograficznej uznałam, że należy przyporządkować zadania biograficzne do dwóch grup, które stanowią uzupełniające się fazy działania biograficznego (w badaniach biograficznych mogą być to fazy prowadzonego wywiadu biograficznego). Pierwsza faza odnosi się do pojęcia stałości i dotyczy rekonstrukcji, uporządkowania historii biograficznej przez osobę. Natomiast druga faza zawierająca się w pojęciu zmiany zakłada reinterpretację wcześniej opisanej czy opowiedzianej historii życia, pozwala zobaczyć ją w nowej perspektywie, w innym kontekście, a także zrozumieć jej złożoność. Tego typu działanie ma na celu umożliwienie innego spojrzenia na siebie, swoje życie, podejmowane działania, cele czy zadania. Pomaga dostrzec nowe możliwości życiowe oraz obszary zaniedbywane przez osobę, które mogłyby przyczynić się do spełnienia i dać szansę samorealizacji. Wprowadzając fazę zmiany, nawiązuję do założeń Sama Keena, który sugerował, żeby człowiek każdą historię dotyczącą życia opowiadał na wiele różnych sposobów. Jego zdaniem „odwracanie” historii już opowiedzianych i tworzenie w ich miejsce historii nowych i im przeciwstawnych, a także uwzględnianie nowych punktów widzenia pomaga opowiadającemu zauważyć i zrozumieć niepowtarzalny charakter własnego życia, a także pozwala uwolnić się z niewoli nieuświadomionych ,skryptów” i uwarunkowań. Sama zmiana formy opowiadania o życiu pozwala na to, aby człowiek mógł dostrzec nowe możliwości w swoim życiu, poszerza poczucie wpływu na własne życie, uświadamia, że każdy w jakimś sensie kształtuje sam własną biografię i jej obraz ${ }^{41}$. Próba wywołania modyfikacji opowiadania o życiu poprzez odpowiednio dobrane zadania biograficzne i ich etapy jest inspirowana teorią, ale samym zamierzeniem tego typu działań na poziomie dydaktycznym jest wzbogacenie narracji, inspiracja i prowokacja do zmiany podejścia osoby do własnego życia. Na poziomie badawczym zaś celem byłaby analiza, jak osoby wprowadzają zmiany w swoją historię o życiu, w jakim aspekcie i zakresie odnoszą się do pewnych „skryptów” i schematów

40 K. Lasocińska, Transgresje..., dz. cyt., s. 181-182.

41 M. Opoczyńska, Sama Keena ,, mityczna podróż do wewnątrz”, [w:] A. Gałdowa (red.), Wybrane zagadnienia z psychologii osobowości, Wydawnictwo Uniwersytetu Jagiellońskiego, Kraków 1999, s. $139-150$. 
opowiadania o własnym życiu, a także jakie stosują zabiegi narracyjne, które pozwalają im podtrzymać i zachować jedną wersję opowieści i jakie, żeby je przełamać. Ostatni etap aktywności biograficznej, również należący do fazy zmiany, dotyczy stworzenia projektu wizji własnej przyszłości. Etap ten zakłada, że osoba opowiadająca własną historię życia odnajdzie inspiracje w podjętych etapach aktywności autobiograficznej do zbudowania wizji własnej przyszłości, która przyczyni się do poprawy jakości jej życia i codziennego funkcjonowania.

\section{Perspektywa stałości i zmiany w zadaniach biograficznych jako bodziec do kreatywności}

Odnosząc się dokładniej do podziału działań biograficznych na obszar stałości i zmiany w aspekcie dydaktyki biograficznej i badań biograficznych, wyjaśnię bliżej wcześniej wskazane dwie fazy.

Faza pierwsza akcentuje ,stałość” - zakłada wprowadzanie takich aktywności autobiograficznych, które mają na celu stymulowanie wypowiedzi biograficznej, przywołanie wspomnień, wywołanie narracji biograficznej. Łączy się zatem z konstruowaniem opowieści autobiograficznej, pozwala stworzyć uporządkowaną strukturę (najczęściej linearną) ważnych wydarzeń życia, a także określić ich znaczenie dla osoby. Faza druga akcentuje „zmianę”, została nazwana przeze mnie ,życiem na opak”, gdyż ma na celu odejście od schematu myślenia o swoim życiu, reinterpretację zdarzeń, zmianę perspektywy postrzegania doświadczeńn ${ }^{42}$. Pozwala na konstruowanie alternatywnych historii, narracji o życiu, odbiegających od pierwotnej struktury. Powinna łączyć się z myśleniem twórczym, kreatywnością, autokreacją i zachętą do transgresji twórczych. Może mieć charakter bardziej zindywidualizowany niż faza pierwsza, mniej oczywisty, zaskakujący, wychodzący poza wcześniej przyjętą zasadę i strukturę interpretacji własnej biografii.

Proponowany przeze mnie podział aktywności związanej z uczeniem biograficznym ilustruje tabela 1 .

Tabela 1. Podział na dwie fazy - stałość i zmiana na warsztacie autobiograficznym (w zadaniach czy odniesieniach biograficznych)

\begin{tabular}{|l|l|}
\hline \multirow{2}{*}{ Faza I - STAŁOŚĆ } & ETAP I - Inspiracja do refleksji biograficznej, „,rozgrzewka” biograficzna \\
\cline { 2 - 3 } & $\begin{array}{l}\text { ETAP II - Zadania inspirujące refleksję biograficzną i porządkowanie materiału biograficznego } \\
\text { opartego na pewnej strukturze, biografia retrospektywna }\end{array}$ \\
\hline \multirow{2}{*}{ Faza II - ZMIANA } & $\begin{array}{l}\text { ETAP III - „Życie na opak”, zmiana perspektywy patrzenia na biografię, dostrzeganie } \\
\text { nowych znaczeń. Przewartościowanie, reinterpretacja. Twórcze spojrzenie na własne życie, } \\
\text { przekraczanie schematów, odkrywanie nowych możliwości analizy i interpretacji życia }\end{array}$ \\
\cline { 2 - 2 } & $\begin{array}{l}\text { ETAP IV - Biografia prospektywna, biografia w ujęciu własnego rozwoju, planowana } \\
\text { przyszłość, cele i marzenia. Wizja własnego rozwoju }\end{array}$ \\
\hline
\end{tabular}

Źródło: opracowanie własne.

${ }^{42}$ Zob. K. Lasocińska, Życie na opak..., dz. cyt. 
W tabeli zawarto podział na dwie fazy działania biograficznego, ale także wskazano takie etapy, które służą narracji biograficznej, czyli etap ,rozgrzewki” obejmujący proste zadania umożliwiające wstępną refleksję biograficzną, etap „biografii retrospektywnej”, a w fazie drugiej etap poszukiwań nowej interpretacji biograficznej (,życie na opak”), na koniec etap „,biografii prospektywnej”, który dotyczy myślenia o przyszłości i projektowania własnego rozwoju.

Pojawia się pytanie o to, w jaki sposób można wywołać zmianę perspektywy widzenia historii swojego życia i jej interpretacji? Odwołując się do własnych doświadczeń dydaktycznych, a także do opracowań teoretycznych, uznaję, że szczególnie inspirujące może być odwołanie się do przykładów i zaleceń pedagogiki i dydaktyki twórczości ${ }^{43}$. W zadaniach biograficznych pomocne może być stosowanie metod i środków pobudzających wyobraźnię dorosłych i myślenie twórcze. Przykładem jest wizualne ujmowanie biografii poprzez różne formy graficzne, działania stymulowane obrazami, zdjęciami, rysunkami, które mogą być wykonane w prosty sposób przez osobę bądź stanowić uzupełnienie gotowych rysunków czy diagramów. Użyteczne jest wykorzystanie innych działań o charakterze artystycznym nawiązujących do zadań z zakresu arteterapii, może być to aktywność związana z muzyką, poezją, literaturą, tańcem, filmem, ale także można włączyć elementy dramy czy sztuki użytkowej. Ważną metodą pobudzającą wyobraźnię twórczą i myślenie biograficzne jest odwoływanie się na warsztacie biograficznym do metafor związanych z biografią, jak na przykład wykorzystanie określeń, takich jak: życie jako podróż, mapa życia, życie jako książka, koło życia i inne. Metafora jest ważnym czynnikiem myślenia twórczego ${ }^{44}$, poszerza wyobraźnię, pomaga ujmować rzeczy i zjawiska w nowy, indywidualny i często oryginalny sposób. Pozwala na zmianę perspektywy widzenia własnego życia lub ważnych zdarzeń, a także dostrzeganie jego najważniejszych wartości, które warto rozwijać. Ponadto w działaniach autobiograficznych znaczenie mogą mieć różnego rodzaju transformacje, czyli dokonywane przez autora opowieści przekształcenia w obrębie struktury historii, bohatera opowieści czy zakończenia opowiadania o życiu. Za szczególnie wartościowe w obszarze dydaktyki biograficznej i twórczej uważam stawianie pytań wywołujących ciekawość poznawczą i refleksję oraz pozwalających na zmianę punktu widzenia wobec zdarzeń i ich interpretacji ${ }^{45}$. Znaczące może się okazać również wywołanie „dialogu z samym sobą”, który prowadzi osoba rekonstruująca swoją biografię. Podejście to może pozwolić na zróżnicowanie znaczeń nadawanych wydarzeniom i zmianę perspektywy czasowej poprzez podejmowanie dialogów temporalnych. Dialog z samym sobą jest formą konfrontacji różnych aspektów własnego ,ja”, stymuluje myślenie twórcze, pozwala na uwzględnienie różnych, czasem trudnych do ujawnienia,

43 K. Lasocińska, J.K. Wawrzyniak, dz. cyt.; K. Lasocińska, Doświadczenia autobiograficzne jako możliwość wspomagania twórczego rozwoju, [w:] A. Glińska-Lachowicz (red.), Arteterapia w działaniu. Propozycje warsztatów i działań arteterapeutycznych, Wydawnictwo Difin, Warszawa 2016; K.J. Szmidt, Pedagogika twórczości, GWP, Sopot 2013.

44 W. Limont, Uczeń zdolny. Jak go rozpoznać i jak z nim pracować, GWP, Poznań 2005.

45 K.J. Szmidt, ABC kreatywności, Wydawnictwo Difin, Warszawa 2010. 
potrzeb czy dążeń osoby ${ }^{46}$. Przykładem może być próba odpowiedzi na pytanie: „Gdybyś mógł podjąć rozmowę z samym sobą 10 lat temu, jakie trzy ważne wskazówki przekazałbyś sobie?” oraz „Gdybyś mógł podjąć rozmowę z samym sobą za 10 lat, jakie trzy pytania zadałbyś sobie?”. W działaniu biograficznym można również zainicjować proces tworzenia „opowieści transgresyjnej”, zakładającej przekraczanie własnych barier. Taką inspirację stanowi zadanie: „Przypomnij sobie i opowiedz o wydarzeniu, kiedy uczyniłeś coś / doświadczyłeś czegoś, co się nie zgadzało z twoim schematem doświadczenia, było zupełnie inne, nowe, nietypowe dla twojego stylu działania/postępowania" ${ }^{47}$. Przekształcenia i transformacje dokonywane w odniesieniu do własnej opowieści o życiu i sposobów interpretowania zdarzeń mają na celu odnajdywanie nowych w swoim życiu wartości, znaczeń i kierunków rozwoju. Dlatego zakładam, że ostatni etap analizy własnej biografii powinien odnosić się do przyszłości i uwzględniać wizję i plany na przyszłość, które mogą stać się bardziej zróżnicowane i precyzyjne po przejściu proponowanych faz.

\section{Podsumowanie}

Rozwój człowieka dorosłego można ujmować jako proces uwalniania się od narzucanych wzorów i konstruowanie własnej drogi życia. Jest to podejście trafne tym bardziej, że świadome kształtowanie siebie i swojego życia przez osobę dorosłą coraz częściej staje się wymogiem współczesnej rzeczywistości i motywuje do rozwijania określonych kompetencji biograficznych. Kompetencje te łączą się z refleksyjnością, skłonnością do analizy doświadczeń, rozumieniem siebie samego, a także z kreatywnością pomagającą ufać samemu sobie i podejmować ryzyko zmiany. W związku z tym można uznać, że współczesnym wyzwaniem edukacyjnym staje się szersze włączenie aktywności biograficznej w działania dydaktyczne i praktykę edukacyjną poprzez proponowanie uczącym się takich zadań, które pozwalają na autorefleksję, twórczy stosunek do zdarzeń, przemianę własnej codzienności, pełniejsze wykorzystanie posiadanych zasobów, realizację pasji i zainteresowań.

Warsztat autobiograficzny jest ciekawą formą twórczej pracy z osobami dorosłymi, pomaga lepiej poznać siebie, własne potrzeby, znaczenie doświadczeń życia, ale także zrozumieć innych, ich sposób patrzenia na świat. Ponadto zadania biograficzne pozwalają przełamywać bariery i ograniczenia, wychodzić poza własne schematy poznawcze. Dają możliwość kształtowania siebie, swojego życia, kreowania twórczej codzienności i dostrzegania wartości tego, co niecodzienne, inne, odbiegające od rutyny. Warsztat autobiograficzny sprzyja kreatywności w działaniach codziennych, poszerza możliwości autokreacji, inspiruje do transgresji twórczych, jeśli opiera się nie tylko na zbieraniu doświadczeń, gromadzeniu wspomnień i nadawaniu im porządku, ale również ujawnia ważny aspekt

${ }^{46}$ P.K. Oleś, Dialogowe Ja, zarys teorii, inspiracje badawcze, ciekawsze wyniki, [w:] P.K. Oleś, M. Puchalska-Wasyl (red.), Dialog z samym soba, PWN, Warszawa 2011, s. 143-171.

47 Zadanie opracowane na podstawie: U. Tokarska, W poszukiwaniu jedności i celu. Wybrane techniki narracyjne, [w:] A. Gałdowa (red.), Wybrane zagadnienia z psychologii osobowości, Wydawnictwo Uniwersytetu Jagiellońskiego, Kraków 1999, s. 169-204. 
możliwości zmiany struktury opowieści o własnym życiu, jej modyfikacji, poszukiwania różnych form porządkowania doświadczenia. Ma to na celu skłonienie jednostki do reinterpretacji doświadczeń, poszukania możliwości zobaczenia ich inaczej, uświadomienia sobie ważnych wartości, stanowi też zachętę do podejmowania nowych kierunków działania, przełamywania barier. W związku z tym w zadaniach biograficznych warto zwrócić uwagę na możliwości przekraczania przyjętego porządku i poszukiwania możliwości kształtowania indywidualnego projektu życia. To ujęcie wydaje się szczególnie istotne w sytuacjach krytycznych, przełomowych, niedookreślonych, wymagających radzenia sobie z trudnymi emocjami i własnym zagubieniem. Spojrzenie inaczej na własne życie, poszukanie innej interpretacji zdarzeń pozwala zrozumieć istotę problemu, sprzyja poszukiwaniu nowych rozwiązań oraz odkrywaniu ważnych wartości na kolejnych etapach życia. Tak rozumiany warsztat autobiograficzny jest możliwością uczenia się z doświadczeń, odkrywania siebie w sytuacji przemian, dostrzegania złożoności życia, jego sensu i wartości. Ponadto inspiruje do refleksji nad różnymi aspektami czasu, zachodzącymi zmianami i ich znaczeniem dla osoby. Pozwala osiągać mądrość życiową i dojrzałość. Warsztat autobiograficzny jest zatem zachętą i wskazówką, jak odnajdywać inspiracje w takich obszarach doświadczeń, które zakładają ciągłość, trwałość, stabilność, powtarzalność, a także wspomaga otwartość uczestnika wobec doświadczeń zaburzających codzienny porządek, zakładających zmiany, przemijanie, niepewność, niedookreślenie, niestabilność, doświadczenia transgresyjne. Tym samym podkreśla wieloaspektowość rozwoju dorosłych. Pokazuje uczenie biograficzne jako ważny element kształtowania siebie i stawania się twórcą własnej biografii. Prezentowany porządek i struktura zadań biograficznych, przedstawione w tym artykule, mają zainspirować uczestnika warsztatów autobiograficznych do poszukiwania nowych kierunków działania bądź dostrzegania ważnych i niedocenionych wartości w codziennym życiu. Porządek ten zakłada twórczy rozwój osoby poprzez zadania i odniesienia biograficzne. Pomaga osobie prowadzącej zajęcia w zachęceniu uczących się do budowania własnej narracji biograficznej, uczenia się z życia, tworzenia opowieści o życiu, która jest transgresyjna, twórcza, wieloaspektowa, barwna. Inspiruje do konstruowania własnych planów i projektów na przyszłość. Wskazany przeze mnie przebieg konstruowania zadań biograficznych ma zastosowanie w aspekcie dydaktyki biograficznej, ale także może być częścią badań biograficznych pozwalających na analizę postaw twórczych badanych osób dorosłych. Warsztat autobiograficzny jest zatem skierowany do osób zainteresowanych edukacyjnym, twórczym, terapeutycznym charakterem działań autobiograficznych, dydaktyką biograficzną i badaniami biograficznymi.

\section{Bibliografia}

Bauman Z., Ptynne czasy. Życie w epoce niepewności, Wydawnictwo Sic!, Warszawa 2007.

Beck U., Spoleczeństwo ryzyka. W drodze do innej nowoczesności, Wydawnictwo Naukowe „Scholar”, Warszawa 2002.

Beck U., Giddens A., Lash S., Przedmowa, [w:] tychże, Modernizacja refleksyjna, PWN, Warszawa 2009. 
Bugajska B., Timoszczyk-Tomczak C., Podróż w czasie. Warsztat rozwoju osobistego osób starszych, Wydawnictwo Naukowe Uniwersytetu Szczecińskiego, Szczecin 2014.

Czerniawska O., Drogi edukacyjne i ich meandry, [w:] E. Dubas, O. Czerniawska (red.), Drogi edukacyjne i ich biograficzny wymiar, Biblioteka Edukacji Dorosłych, Warszawa 2002.

Czerniawska O., Przedmowa, [w:] K. Lasocińska, J.K. Wawrzyniak, Autobiografia jako twórcze wyzwanie. Scenariusze warsztatów biograficznych, Wydawnictwo Akademickie Żak, Warszawa 2013.

Dominicé P., Uczyć się z życia. Biografia edukacyjna w edukacji dorostych, WSHE, Łódź 2006.

Giddens A., Nowoczesność i tożsamość. „Ja” i społeczeństwo w epoce późnej nowoczesności, PWN, Warszawa 2001.

Giddens A., Życie w spoleczeństwie posttradycyjnym, [w:] U. Beck, A. Giddens, S. Lash, Modernizacja refleksyjna, PWN, Warszawa 2009.

Havighurst R.J., Developmental Tasks and Education, Longman, Nowy Jork-Londyn 1981.

Kozielecki J., Psychotransgresjonizm. Nowy kierunek w psychologii, Wydawnictwo Akademickie Żak, Warszawa 2001.

Kuleta M., Człowiek jako kreator zmian w swoim życiu, [w:] D. Kubacka-Jasiecka (red.), Człowiek wobec zmiany. Rozważania psychologiczne, Wydawnictwo Uniwersytetu Jagiellońskiego, Kraków 2002.

Lalak D., Życie jako biografia. Podejście biograficzne w perspektywie pedagogicznej, Wydawnictwo Akademickie Żak, Warszawa 2010.

Lasocińska K., Autobiografia jako autokreacja. Twórcze aspekty procesu myślenia autobiograficznego w edukacji dorostych, [w:] E. Dubas, J. Stelmaszczyk (red.), Biografia i badanie biografii: biografie edukacyjne. Wybrane konteksty, t. 3, Wydawnictwo Uniwersytetu Łódzkiego, Łódź 2014.

Lasocińska K., Doświadczenia autobiograficzne jako możliwość wspomagania twórczego rozwoju, [w:] A. Glińska-Lachowicz (red.), Arteterapia $w$ działaniu. Propozycje warsztatów $i$ działań arteterapeutycznych, Wydawnictwo Difin, Warszawa 2016.

Lasocińska K., Kryzys połowy życia - zdobywanie kompetencji autokreacyjnej $i$ dą̇enie do madrości, [w:] E. Dubas, J. Stelmaszczyk (red.), Biografie edukacyjne - wybrane konteksty, Wydawnictwo Uniwersytetu Łódzkiego, Łódź 2014.

Lasocińska K., Rozwijanie i wspomaganie kompetencji biograficznych na Uniwersytecie Trzeciego Wieku w Akademii Humanistyczno-Ekonomicznej w Łodzi, [w:] E. Woźnicka, Ł. Zaorski-Sikora (red.), Akademia - idee, metody, działania, Wydawnictwo Akademii Humanistyczno-Ekonomicznej w Łodzi, Łódź 2013.

Lasocińska K., Transgresje jako aspekt wzbogacania aktywności twórczej i uczenia się w oparciu o doświadczenia biograficzne, [w:] A. Ciążela, S. Jaronowska (red.), Transgresja jako motyw refleksji nad wychowaniem, Wydawnictwo Akademii Pedagogiki Specjalnej, Warszawa 2017.

Lasocińska K., Twórcze aspekty działań biograficznych, [w:] K. Lasocińska, J.K. Wawrzyniak, Autobiografia jako twórcze wyzwanie. Scenariusze warsztatów biograficznych, Wydawnictwo Akademickie Żak, Warszawa 2013.

Lasocińska K., Życie na opak - scenariusze zajęć autobiograficznych, [w:] K. Lasocińska, J.K. Wawrzyniak, Autobiografia jako twórcze wyzwanie. Scenariusze warsztatów biograficznych, Wydawnictwo Akademickie Żak, Warszawa 2013. 
Lasocińska K., Życie poza schematem. Analiza biografii twórców, Wydawnictwo Akademii Humanistyczno-Ekonomicznej w Łodzi, Łódź 2011.

Lasocińska K., Wawrzyniak J.K., Autobiografia jako twórcze wyzwanie. Scenariusze warsztatów biograficznych, Wydawnictwo Akademickie Żak, Warszawa 2013.

Levinson D.J., The mid-life transition: A period in adult psychosocial development, „Psychiatry" 1977, No. 40.

Levinson D.J., A conception of adult development, „American Psychologist” 1986, No. 41.

Limont W., Twórczość w aspekcie cyklu życia, [w:] E. Dombrowska, A. Niedźwiecka (oprac.), Twórczość - wyzwanie XXI wieku, Oficyna Wydawnicza „Impuls”, Kraków 2003.

Limont W., Uczeń zdolny. Jak go rozpoznać i jak z nim pracować, GWP, Poznań 2005.

Oleś P.K., Dialogowe Ja, zarys teorii, inspiracje badawcze, ciekawsze wyniki, [w:] P.K. Oleś, M. Puchalska-Wasyl (red.), Dialog z samym soba, PWN, Warszawa 2011.

Opoczyńska M., Sama Keena ,,mityczna podróż do wewnątrz”, [w:] A. Gałdowa (red.), Wybrane zagadnienia z psychologii osobowości, Wydawnictwo Uniwersytetu Jagiellońskiego, Kraków 1999.

Pietrasiński Z., Rozwój człowieka dorosłego, „Wiedza Powszechna”, Warszawa 1990.

Pietrasiński Z., Ekspansja pięknych umystów. Nowy renesans i ożywcza autokreacja, Wydawnictwo CiS, Warszawa 2008.

Przetacznik-Gierowska M., Tyszkowa M., Psychologia rozwoju człowieka, Wydawnictwo Naukowe PWN, Warszawa 2000.

Pufal-Struzik I., Podmiotowe i społeczne warunki twórczej aktywności artystów, Wszechnica Świętokrzyska, Kielce 2006.

Szmidt K.J., ABC kreatywności, Wydawnictwo Difin, Warszawa 2010.

Szmidt K.J., Pedagogika twórczości, GWP, Sopot 2013.

Tokarska U., W poszukiwaniu jedności i celu. Wybrane techniki narracyjne, [w:] A. Gałdowa (red.), Wybrane zagadnienia z psychologii osobowości, Wydawnictwo Uniwersytetu Jagiellońskiego, Kraków 1999.

\section{Streszczenie \\ Kształtowanie twórczej codzienności. Warsztat autobiograficzny jako metoda wspomagania kreatywności dorosłych}

W artykule przedstawiono możliwości wspomagania kreatywności osób dorosłych poprzez warsztat autobiograficzny i zadania biograficzne. Opisano założenia teoretyczne, ale także przedstawiono propozycję działań praktycznych, kierując czytelnika do takich form aktywności biograficznych i edukacyjnych, które wspomagają możliwości autokreacji, transgresji i kreatywności osoby na różnych etapach jej dorosłego życia. Celem jest refleksja nad tym, jak możemy stymulować rozwój osobisty dorosłych poprzez świadome i twórcze odnoszenie się do doświadczeń życia w kontekście przeszłości, teraźniejszości i przyszłości.

Słowa kluczowe: warsztat autobiograficzny, kreatywność, autokreacja, transgresje, edukacja dorosłych 


\section{Summary}

Shaping creative everyday life. An autobiographical workshop as a method of supporting the creativity of adults

In this article I present ways of supporting the creativity of adults through autobiographical workshops and biographical tasks. I describe both theoretical assumptions and proposals for practical activities. I note forms of biographical and educational activities that support the possibility of self-creation, transgression and the creativity of an individual at various stages of adult life. The aim is to reflect on how we can stimulate adult personal development through conscious and creative reference to life experiences in the context of the past, present and future.

Keywords: autobiographical workshop, creativity, self-creation, transgression, adult education 


\section{Przygotowanie do samodzielności życiowej usamodzielnianych wychowanków placówek opiekuńczo-w ychowawczych}

\section{Wprowadzenie}

Przygotowanie do samodzielności życiowej wydaje się jednym z kluczowych elementów procesu wychowania każdego człowieka. Bez wątpienia proces ten jest niebywale złożony, potrzebny i ważny. Wpojenie młodym ludziom podstawowych cech umożliwiających samodzielne bytowanie jest zabiegiem trudniejszym, gdy dokonuje się on w środowisku zastępczym bez wsparcia rodziców. Taką drogę do osiągania samodzielności życiowej przechodzą wychowankowie placówek opiekuńczo-wychowawczych (POW) Podopieczni ci są często nazywani sierotami społecznymi², a placówki, w których przebywają, potocznie nazywa się domami dziecka. Należy przy tym pamiętać, że każdy wychowanek instytucjonalnej pieczy zastępczej podlega sformalizowanemu procesowi usamodzielnienia, który tym samym nie dotyczy dzieci i młodzieży przebywającej w domu

1 Doktorant Dolnośląskiej Szkoły Wyższej we Wrocławiu, magister pedagogiki, pracownik Młodzieżowego Ośrodka Wychowawczego w Herbach, pracownik Schroniska dla Bezdomnych Rodzin i Mężczyzn im. Św. Brata Alberta w Częstochowie, były pracownik Całodobowej Placówki Opiekuńczo-Wychowawczej im. Św. Dominika Savio w Częstochowie.

2 Wychowankowie placówek opiekuńczo-wychowawczych (potocznie domów dziecka) są również określani mianem sierot społecznych. Szerzej na ten temat można przeczytać m.in. w: I. Motow, M. Mielczarek, Funkcjonowanie emocjonalne i społeczne wychowanków domów dziecka w aspekcie doznawanego sieroctwa społecznego, ,Pedagogika Rodziny” 2018, nr 8(1), s. 72. 
rodzinnym. Zasady usamodzielnienia podopiecznych POW, którzy opuszczają pieczę zastępczą regulują przepisy zawarte w ustawie z dnia 9 czerwca 2011 roku $^{3}$.

POW według przepisów prawnych należy do instytucjonalnej pieczy zastępczej, która w obecnie obowiązującym prawie jest przeznaczona dla sierot oraz dzieci, których rodzicom zostały ograniczone prawa rodzicielskie lub całkowicie zostali ich pozbawieni ${ }^{4}$. Takie sankcje wobec rodziców lub rodzica stosuje się w przypadku, kiedy wymaga tego dobro dziecka. Jeżeli w wyniku nałożonych konsekwencji żadnemu z rodziców nie przysługuje władza rodzicielska lub jeżeli rodzice są nieznani, dla dziecka ustanawia się opiekę ${ }^{5}$ Prawo do zagwarantowania opieki każdemu dziecku pozbawionemu rodziców stanowi między innymi treść art. 72 Konstytucji Rzeczypospolitej Polskiej ${ }^{6}$. Podobnie do wskazanej kwestii odniesiono się w art. 20 Konwencji o Prawach Dziecka, według której każdemu dziecku pozbawionemu naturalnego środowiska rodzinnego przysługuje specjalne prawo do ochrony i pomocy ze strony każdego państwa, które konwencję ratyfikowało ${ }^{7}$. POW są najbardziej rozpowszechnionymi i tradycyjnymi formami opieki całkowitej nad sierotami społecznymi. Przejmują one podstawowe zadania, jakie zwykle przypisywane są rodzicom ${ }^{8}$. To typ placówki socjalizacyjnej, funkcjonującej całodobowo jako instytucjonalna forma opieki nad dzieckiem. Jej działalność polega głównie na zaspokajaniu podstawowych potrzeb dzieci, zapewniając im przy tym całkowitą opiekę, wychowanie, kształcenie oraz wyrównywanie opóźnień szkolnych i rozwojowych. Realizacji wymienionych założeń dokonuje się poprzez organizowanie szeregu specjalistycznych zajęć, a w razie potrzeby także odpowiedniej rehabilitacji ${ }^{9}$.

\section{Teoretyczne podłoże samodzielności}

W literaturze pojęcie samodzielności najczęściej jest utożsamiane z autonomią, dojrzałością, niezależnością oraz z umiejętnością samodzielnego życia. Samodzielność to także jedna $z$ wielu cech, które wchodzą w zakres struktury osobowościowej ${ }^{10}$. Intuicyjnie

3 Ustawa z dnia 9 czerwca 2011 r. o wspieraniu rodziny i systemie pieczy zastępczej, Dz.U. 2011, nr 149, poz. 887 z późn. zm.

${ }^{4}$ U. Kamińska, Zarys metodyki pracy opiekuńczo-wychowawczej w rodzinnych i instytucjonalnych formach wychowania, Wydawnictwo Uniwersytetu Śląskiego, Katowice 2005, s. 27.

5 Ustawa z dnia 25 lutego 1964 r. Kodeks rodzinny i opiekuńczy, Dz.U. 1964, nr 9, poz. 59, art. 93, 94, 107, 109-111.

${ }^{6}$ Konstytucja Rzeczypospolitej Polskiej z dnia 2 kwietnia 1997 r. uchwalona przez Zgromadzenie Narodowe w dniu 2 kwietnia 1997 r., Dz.U. 1997, nr 78, poz. 483.

7 Konwencja o Prawach Dziecka przyjęta przez Zgromadzenie Ogólne Narodów Zjednoczonych 20 listopada 1989 r., Dz.U. 1991, nr 120, poz. 526.

${ }^{8}$ U. Kamińska, Zranione dzieciństwo. Wychowankowie domu dziecka mówia, Wydawnictwo Naukowe „Śląsk”, Katowice 2000, s. 13.

9 U. Bartnikowska, K. Ćwirynkało, Rodziny adopcyjne i zastepcze dziecka z niepetnosprawnościa, Oficyna Wydawnicza „Impuls”, Kraków 2013, s. 53 cyt. za: J. Mańka, K. Ornacka, Trudne dzieciństwo i rodzicielstwo - wybrane aspekty funkcjonowania rodzin zastępczych $w$ Polsce $w$ perspektywie socjologicznej, [w:] A. Żukiewicz (red.), Rodzicielstwo zastępcze w perspektywie teoretycznej i praktycznej, Wydawnictwo Edukacyjne „Akapit”, Toruń 2011.

10 D. Ruszkiewicz, Samodzielność życiowa dorostych córek nadopiekuńczych ojców, „Pedagogika Rodziny” 2018, nr 8(1), s. 88 cyt. za: A. Buczel, Samodzielność jako cecha osobowości, „Studia Philosophiae Christianae" 1993, nr 29(1), s. 115. 
jest ona rozumiana nie tylko jako pewna cecha osobowości. Wynika także z wewnętrznej potrzeby niezależnego zdobywania i gromadzenia doświadczeń życiowych niezbędnych jednostce. To także próba wiążąca się z pokonywaniem przeszkód oraz ze sprawdzeniem swoich umiejętności w różnych sytuacjach. Dążenie do samodzielności przyczynia się do poznawania własnych granic i możliwości. Jej osiąganie powiązane jest ze zdolnością ponoszenia odpowiedzialności oraz konsekwencji za swoje czyny ${ }^{11}$.

J. Świrko-Pilipczuk stwierdza, że samodzielność „może być właściwa człowiekowi w różnym stopniu i zakresie. Zmienia się w różnych okresach życia człowieka [...] może mieć różny zakres ze względu na formy i rodzaje działań" ${ }^{12}$. Samodzielność to również pewnego rodzaju atrybut dorosłości, określona forma aktywności, potrzeba psychiczna, warunek prawidłowego rozwoju, a nawet postawa życiowa ${ }^{13}$. W tym rozumieniu ,samodzielność" porównuje się nie tylko z autonomią, ale i z dojrzałością biopsychospołeczną oraz ze zdolnością do samodzielnego bytowania w społeczeństwie ${ }^{14}$. Zdaniem M. Winiarskiego samodzielny człowiek to taki, który w żaden sposób nie jest uzależniony od nikogo, a przy tym sam radzi sobie z napotykającymi go trudnościami ${ }^{15}$. T. Tomaszewski społeczną samodzielność utożsamia z niezależnością w myśleniu i działaniu jednostki od nacisku i pomocy innych osób ${ }^{16}$. Z. Dąbrowski definiuje samodzielność jako „osiągniecie takiego poziomu rozwoju fizycznego, psychicznego i społecznego, który umożliwia względnie samodzielne i niezależne funkcjonowanie w społeczeństwie"17. Na potrzeby badań przyjęto rozumienie samodzielności zgodne z koncepcją G. Gajewskiej. Zdaniem autorki jednostka samodzielna to taka, która cechuje się odpowiednim przygotowaniem do życia rodzinnego, zawodowego, społecznego i obywatelskiego. Wymienione kategorie to cztery podstawowe zadania, jakie powinny być zrealizowane przez placówkę w celu usamodzielnienia wychowanka ${ }^{18}$. Wybraną koncepcję uznano za słuszną, dlatego uwzględniono ją przy konstrukcji pytań badawczych i narzędzia badawczego.

11 Z. Woźniak, Samodzielność życiowa osób z lekką i umiarkowaną niepelnosprawnościa intelektualna w świetle danych uzyskanych za pomoca nowego narzędzia pomiaru, „Niepełnosprawność i Rehabilitacja” 2017, nr 3, s. 63.

12 J. Świrko-Pilipczuk, Sytuacje edukacyjne podstawa procesu kształcenia i rozwijania samodzielności, [w:] K. Denek, F. Bereźnicki, J. Świrko-Pilipczuk (red.), Proces kształcenia i jego uwarunkowania, Agencja Wydawnicza „Kwadra”, Szczecin 2003, s. 74-75.

13 I. Mudrecka, Samodzielność, [w:] J.M. Śnieciński (red.), Encyklopedia pedagogiczna XXI wieku, t. 5 , Wydawnictwo Akademickie ,Żak”, Warszawa 2006, s. 597.

${ }^{14}$ I. Motow, M. Motow-Czyż, Proces usamodzielnienia wychowanków z zakładów resocjalizacyjnych, „Pedagogika Rodziny” 2015, nr 5(4), s. 31.

15 M. Winiarski, Rodzina-szkoła-środowisko lokalne. Problemy edukacji środowiskowej, Instytut Badań Edukacyjnych, Warszawa 2000, s. 189.

16 T. Tomaszewski, Z zagadnień psychologii samodzielności, „Kwartalnik Pedagogiczny” 1958, nr 1, s. 55.

17 Z. Dąbrowski, Pedagogika opiekuńcza w zarysie, cz. 2, Wydawnictwo WSP, Olsztyn 1995, s. 70.

18 G. Gajewska, Pedagogika opiekuńcza i jej metodyka, Wydawnictwo Naukowe Uniwersytetu Zielonogórskiego, Zielona Góra 2004, s. 109. 


\section{Metodologia badań}

Badania osadzono w metodologii jakościowej utożsamianej z paradygmatem interpretatywnym. Ich przedmiotem uczyniono osiąganie samodzielności życiowej przez usamodzielnianych wychowanków POW. Celem badań była próba odpowiedzi na problem główny zawarty w pytaniu: „W jaki sposób POW (potocznie zwane domami dziecka) przygotowują swoich usamodzielnianych wychowanków do samodzielności życiowej?”. Tak sformułowany problem główny uzupełniono o cztery problemy szczegółowe, które kolejno dotyczyły przygotowania do samodzielności: rodzinnej, zawodowej, społecznej i obywatelskiej. Przyjęty model badań jakościowych pozwolił na rezygnację z wcześniejszego stawiania hipotez ${ }^{19}$. W badaniu zastosowano metodę indywidualnych przypadków, zwaną też studium indywidualnych przypadków ${ }^{20}$. Jako technikę badawczą do wybranej metody zastosowano wywiad ${ }^{21}$. Zgodnie z zaleceniami metodologicznymi narzędzie badawcze stanowił kwestionariusz wywiadu składający się z metryczki zawierającej osiem pytań oraz z części zasadniczej, której nadano cztery pytania otwarte. Wyniki pozyskane za pomocą kwestionariusza wywiadu odpowiednio zakodowano i przygotowano do analizy jakościowej.

\section{Dobór próby badawczej}

Badania zostały zrealizowane w 2018 roku. Trwały w okresie od lipca do października. Wzięło w nich udział dziesięciu badanych z dziesięciu różnych POW. Pośród respondentów było trzech dyrektorów placówek, jeden pedagog, pięciu wychowawców oraz jeden pracownik socjalny. Wszystkie osoby badane były płci żeńskiej. Dla pięciu badanych staż pracy w placówce mieścił się w przedziale 10 lat i powyżej, dla czterech osób wyniósł 3-5 lat, a jedna osoba uplasowała się ze stażem między 1-3 lata. Siedem osób, które wzięły udział w badaniu, dysponowało wykształceniem magisterskim. Następne trzy posiadały kolejno stopień doktora, tylko studia licencjackie oraz studia magisterskie wraz z podyplomowymi. Wykształcenie badanych osób oscylowało wokół pedagogiki ze specjalnością opiekuńczo-wychowawczą, resocjalizacyjną, wczesnoszkolną, ale także zdarzały się osoby z wykształceniem psychologicznym, socjologicznym i pracą socjalną. Placówki, w których

19 Zob. A. Wyka, Model badań przez wspólne doświadczanie, czyli o pewnej wersji empirii ,jakościowej”, „Kultura i Społeczeństwo” 1985, nr 2; T. Pilch, T. Bauman, Zasady badań pedagogicznych. Strategie ilościowe i jakościowe, Wydawnictwo Akademickie „Żak”, Warszawa 2001, s. 279.

${ }^{20}$ Wybrana metoda polega na ,analizie jednostkowych losów ludzkich uwikłanych w określone sytuacje wychowawcze lub na analizie konkretnych zjawisk natury wychowawczej przez pryzmat jednostkowych biografii ludzkich z nastawieniem na opracowanie diagnozy przypadku lub zjawiska w celu podjęcia działań terapeutycznych", cyt. za: T. Pilch, T. Bauman, dz. cyt., s. 91-92.

21 Wywiad polega na zadawaniu pytań swojemu respondentowi w celu uzyskania od niego potrzebnych informacji. Zagadnienia poruszane podczas wywiadu powinny mieć związek z wcześniej postawionymi pytaniami badawczymi, cyt. za: A.W. Maszke, Metody i techniki badań pedagogicznych, Wydawnictwo Uniwersytetu Rzeszowskiego, Rzeszów 2008, s. 257. Wywiad to także rozmowa „badającego z respondentem lub respondentami według opracowanych wcześniej dyspozycji lub w oparciu o specjalny kwestionariusz", cyt. za: T. Pilch, T. Bauman, dz. cyt., s. 91-92. 
zostały zrealizowane wywiady mieściły się na terenie: Białegostoku, Żyznowa, Częstochowy, Blachowni, Knurowa, Łodzi i Człuchowa. W trzech przypadkach osoby poprosiły, by w analizie z badań nie uwzględniać miejscowości, w której znajduje się ich placówka, ponieważ miejscowość jest stosunkowo mała i trudno o anonimowość. Prośbę tą wzięto pod uwagę. Niemniej były to placówki z województw łódzkiego i podkarpackiego. Ze wszystkich badanych placówek osiem miało statut publiczny, natomiast dwie były niepubliczne. Średnia liczba wychowanków w każdej placówce wyniosła około dwudziestu.

\section{Analiza badań}

Analizę badań przeprowadzono zgodnie z układem pytań zasadniczych zawartych w narzędziu badawczym. Pierwsze zagadnienie to przygotowanie do samodzielnego życia $\mathbf{w}$ rodzinie. Z uzyskanych wypowiedzi można się dowiedzieć, że aby poprawnie przygotować swoich podopiecznych do samodzielności rodzinnej, POW tworzą tak zwane grupy usamodzielnień. Dzięki temu możliwe jest położenie szczególnego nacisku na wykształcenie podstawowych umiejętności, takich jak: gotowanie, posługiwanie się sprzętem AGD, zarządzanie zasobami finansowymi. Jak wskazali respondenci, ważne są również rozmowy, samodzielne robienie zakupów, wykonywanie codziennych obowiązków domowych, motywacja, wsparcie, ale także wakacje u rodzin.

Z rodzinami wychowanków zwykle jest trudny kontakt, rzadko się angażują w pracę z dziećmi, pomimo że to ich dzieci. Zachęcamy, ale nasze wysiłki przynoszą mizerne efekty. Jednak staramy się pracować z dzieckiem w taki sposób, aby pokazać mu, jak prawidłowo tworzyć więzi, nazywać uczucia, tłumaczyć zachowania dorosłych. Pokazujemy wartości rodzinne, role poszczególnych członków rodziny i wiele innych tematów związanych z funkcjonowaniem rodziny. Metody, którymi pracujemy, są różne: cykliczne programy socjoterapeutyczne, pogadanki, rozmowy indywidualne i w rodzinkach. (Pracownik POW, Wywiad nr 3)

W placówce dzieci i młodzież uczą się samodzielności rodzinnej przez naukę wykonywania różnych prac, jakie konieczne są do prawidłowego funkcjonowania w rodzinie. Należy tu wskazać przede wszystkim umiejętność wydawania i planowania pieniędzy według najważniejszych potrzeb, angażowanie się w opiekę nad młodszymi wychowankami przez pomaganie im w odrabianiu lekcji, odprowadzanie czy przyprowadzanie ze szkoły, uwrażliwianie na oszczędzanie. Jedna z rozmówczyń wskazała, że w placówce nie ma typowych wzorców jak w rodzinie. Świadczy o tym chociażby fakt ciągłej rotacji wychowawców, co zupełnie nie sprzyja budowaniu poprawnych relacji. Ta sama rozmówczyni podkreśliła, że przygotowanie do samodzielności rodzinnej ich podopiecznych jest tym trudniejsze, że trafiają oni do placówki już z pewnym ukształtowanym wzorcem rodzinnym. Zadaniem placówki w tym zakresie jest tłumaczenie wychowankom, jaki wzorzec jest prawidłowy, w jaki sposób i na jakich podstawach należy budować swoje związki partnerskie. Inna respondentka zaznaczyła, że przygotowanie do samodzielnego życia w rodzinie powinno się rozpocząć już od pierwszego dnia pobytu dziecka w placówce. Konieczna jest oczywiście w tym względzie odpowiednia współpraca z jego rodziną. 
Drugą kwestią, którą zbadano, było przygotowanie do samodzielności zawodowej. Odbywało się ono przez edukację zawodową, branie udziału w szkoleniach i kursach zawodowych, podejmowanie pracy w czasie wolnym. Typowymi metodami stosowanymi w tym celu okazały się także rozmowy wychowawcze, narzucanie obowiązków domowych, zachęcanie do udziału w praktykach i stażach zawodowych. Jedna z badanych osób uznała, że przygotowanie do samodzielności zawodowej to również pomoc podopiecznym w znalezieniu pracy po ich usamodzielnieniu się. Praca z wychowankami w celu zdobycia zawodu to wyrabianie dyscypliny, szeroko rozumianej samodzielności i odpowiedzialności. Niezwykle istotną formę pomocy w tym zakresie jedna z rozmówczyń upatrywała w analizie umiejętności i predyspozycji zawodowych oraz w motywowaniu do poszukiwania dorywczego zatrudnienia podczas dni wolnych od nauki szkolnej.

Mobilizujemy wychowanków do podjęcia pracy dorywczej, najczęściej w weekendy. Motywuje się już siedemnastolatków, aby podjęli pracę wakacyjną. Pokazujemy, w jaki sposób mogą szukać pracy, tj. przedstawiamy im propozycje różnych agencji zatrudnienia, młodzieżowych biur pracy, mobilizujemy do podjęcia pracy w restauracjach typu fast food, gdyż tam jest najwięcej możliwości dla młodych osób. Proponujemy kontynuowanie nauki, przekwalifikowanie się. Nauczenie pracy od najmłodszych lat przygotowuje ich do samodzielności zawodowej, odpowiedzialności, punktualności, umiejętności wykonywania poleceń przełożonych. Niestety nie wszyscy garną się do podjęcia pracy. Wytrzymują tylko pracowici, ci, którzy chcą w życiu coś osiągnąć, chcą być niezależni i żyć uczciwie, ambitni. Pozostali nie utrzymują się długo w miejscu pracy, szybko rezygnują, trudność sprawia im praca typu sprzedawca w sklepie odzieżowym, czy pracownik restauracji. Pozostają bierni. Wydaje im się, że wszystko przychodzi $\mathrm{z}$ łatwością. Nie chcą zrozumieć, że na sukces trzeba długo pracować. Zniechęcają się, bo muszą się dostosować do warunków pracy, do innych osób. Nie chce im się ciężko pracować. Nie jest to wina placówki, ale ich osobowości, być może też tego, co wynieśli z domu. (Pracownik POW, Wywiad nr 6)

Głównie przez stawianie nauki wysoko w hierarchii wartości, motywowanie, wyrabianie nawyków uczenia się, zachęcanie do utożsamiania się z ludźmi, którzy dobrze sobie radzą zawodowo, spotkania z takimi ludźmi. Skupianie dorosłych z naszej społeczności lokalnej w krąg przyjaciół placówki i pozyskiwanie pracodawców dla naszych dzieci, rozwój zainteresowań, uświadamianie, że zdobycie wykształcenia to motor życia zawodowego, a także podnoszenie samooceny, zachęcanie do stawiania sobie celów, spotkania z byłymi wychowankami, którzy sobie dobrze radzą w życiu zawodowym. (Pracownik POW, Wywiad nr 10)

Kolejny obszar, jaki zbadano, to przygotowanie do samodzielności społecznej. To zadanie placówki realizowały przez udział w różnych kampaniach społecznych, pogadanki o tematyce zdrowotnej, branie udziału w wolontariacie, zachęcanie do aktywności społecznej, rozwój kulturalny (wyjścia do filharmonii, kina, na koncerty, wystawy, warsztaty twórcze, wycieczki), reprezentowanie placówki na zewnątrz. Sfera społeczna była też kształtowana przy pomocy budowania nowych znajomości i ich utrzymywania z innymi placówkami czy instytucjami. Pracowano na programach socjoterapeutycznych, uczono, jak załatwiać sprawy urzędowe, wypełniać różne druki, w jakim celu powołany jest dany urząd, jak prawidłowo funkcjonować w społeczeństwie według przyjętych norm. Wyposażanie młodego człowieka w podstawowe umiejętności społeczne miało miejsce 
również dzięki takim formom, jak rozmowa wychowawcza, współpraca z instytucjami na rzecz dziecka i rodziny, ale i wspieranie w kontaktach międzyludzkich.

Samo przebywanie w placówce, gdzie jest dużo różnych osobowości przygotowuje te dzieciaki do życia w społeczeństwie. Muszą się dostosować, przestrzegać pewnych norm i zasad. Tego ich uczymy. A także jak przestrzegać prawa, co jest dobre, a co złe. Jest regulamin, różnego rodzaju prelekcje, rozmowy, przykłady. Brakuje jednak kontroli wychowawczej nad zachowaniem wychowanka poza placówką. Nie ma na to przeznaczonych godzin. Nie ma możliwości uczestniczenia w życiu społecznym poza placówką razem z wychowankiem. Musi on sam zderzyć się z rzeczywistością, bazując na tym, co zostało mu przekazane. (Pracownik POW, Wywiad nr 6)

Głównie przez dużą aktywność w społeczności lokalnej przez organizowanie imprez, spotkań w placówce, otwartość na kontakty, poprzez udział w różnych imprezach, uroczystościach, życiu miasta, przez naukę ról społecznych, przez aktywność społeczną (opieka nad bezdomnymi zwierzętami), przez nagradzanie właściwych postaw kolegi, ucznia, członka grupy. (Pracownik POW, Wywiad nr 10)

Ostatnim obszarem badawczym było przygotowanie do samodzielności obywatelskiej. Aby wypełnić tę funkcję wychowawczą, placówki prowadziły z podopiecznymi rozmowy o Polsce, oglądano wiadomości w telewizji, obchodzono główne uroczystości państwowe. Zachęcano pełnoletnich wychowanków do czynnego brania udziału w głosowaniach wyborczych, spotkań z władzami, wpajano odpowiedzialność za własny naród, przekazywano ważne fakty historyczne. Pojawiały się wypowiedzi, w których metodą przygotowania obywatelskiego było wspólne czytanie konstytucji, nauka praw obywatelskich i obowiązków. Uczono znajomości świąt państwowych, rocznic, dawano wzorce i pokazywano, jak powinien prawidłowo funkcjonować obywatel. Niestety, jak się okazało, w niektórych placówkach przygotowanie do samodzielności obywatelskiej było zupełnie pomijane: „rzadko rozmawiamy o tej sferze samodzielności. Tutaj dużą rolę odgrywa szkoła, która jest wsparciem nie tylko dla rodzin, ale także dla placówek opiekuńczo-wychowawczych" (Pracownik POW, Wywiad nr 6).

\section{Wnioski z badań}

Przeprowadzone badania nie pretendują do miana uogólniania. Nie należy bowiem na nielicznej próbie wysuwać ogólnych wniosków wobec metod wychowawczych, jakimi posługują się POW w celu przygotowania wychowanków do samodzielności życiowej. Postępowanie badawcze pozwoliło zbadać zaledwie pewien wycinek rzeczywistości. Jednakże może być on pomocny w dalszych rozważaniach teoretycznych, praktycznych i badawczych.

Badania pokazały, że przygotowanie do samodzielności rodzinnej sprawia placówkom pewne trudności. Były one związane głównie z wcześniejszymi doświadczeniami rodzinnymi wychowanków oraz z wadliwie ukształtowanym u nich modelem rodzinnym. Większość metod i form stosowanych w tym zakresie przez placówki wydaje się poprawna. Jednakże system pracy takich placówek, o czym również informowali respondenci, nie sprzyja prawidłowemu wyposażaniu podopiecznych w kompetencje rodzinne. Wydaje się 
tym samym, że trudno jest zaaranżować w instytucjonalnej formie opieki zastępczej atmosferę rodzinną, a ta przecież jest niezbędna do ukształtowania samodzielności rodzinnej.

Metody, jakie stosowały placówki w celu przygotowania do samodzielności zawodowej, można określić także jako właściwe. Wśród nich należy wymienić przede wszystkim angażowanie podopiecznych w pobieranie nauki zawodu, zachęcanie do udziału w różnych kursach i stażach zawodowych, podejmowanie pracy zarobkowej w dni wolne od nauki szkolnej, wyrabianie poczucia obowiązku oraz angażowanie w prace na rzecz placówki. Równie cenna i skuteczna metoda w wyborze zawodu, jaką stosowały placówki, to preorientacja zawodowa pomagająca określić predyspozycje i kompetencje zawodowe.

Przygotowanie do samodzielnego życia społecznego było realizowane dzięki szeroko pojmowanemu angażowaniu wychowanków w życie społeczne. Niektóre respondentki podkreśliły, że kontrolowanie przygotowania do sfery społecznej ich podopiecznych jest równie trudne, jak w przypadku przygotowania rodzinnego. Na tę okoliczność składa się stwierdzenie, że funkcjonowaniem społecznym jest również to, co ma miejsce poza terenem placówki. Kontrola tych zachowań jest wręcz niemożliwa, dlatego często trzeba bazować tylko na tym, co zostanie wypracowane i zaobserwowane w placówce. Dlatego na tą formę przygotowania powinien być położony szczególny nacisk. Z kolei sama analiza metod wychowawczych, jakie stosowały placówki w tej sferze, wydaje się zasadna.

Przygotowanie do samodzielności obywatelskiej przez niektóre placówki było pomijane lub utożsamiane z przygotowaniem społecznym. Oczywiście w analogię przygotowania społecznego i obywatelskiego nikt nie wątpi. Natomiast warto te sfery rozróżniać, gdyż cechuje je wiele odmiennych elementów. Trzeba przy tym pamiętać, że nie każda osoba żyjąca w zgodzie z normami społecznymi będzie wypełniać podstawowe obowiązki obywatelskie wobec swojego kraju i narodu. Tylko odpowiednie przygotowanie obywatelskie gwarantuje nam wszystkim stworzenie społeczeństwa obywatelskiego.

Jedna $\mathrm{z}$ respondentek stwierdziła, że przygotowanie do samodzielności rodzinnej, zawodowej, społecznej i obywatelskiej w jej placówce jest realizowane za pomocą tych samych metod. Praktyka ta wydaje się nie tyle dość wątpliwa, co mało uściślająca poszczególne formy wychowawcze. Na koniec warto przytoczyć słowa innej rozmówczyni, które z całą pewnością wpasowują się w tematykę całej pracy:

Podstawowe znaczenie w przygotowaniu wychowanka do samodzielności życiowej ma dobra relacja z dzieckiem, duże zaangażowanie wychowawcy, własny przykład, indywidualne podejście do każdego dziecka i dostosowanie się do jego możliwości rozwojowych. (Pracownik POW, Wywiad nr 10)

\section{Bibliografia}

Bartnikowska U., Ćwirynkało K., Rodziny adopcyjne i zastępcze dziecka z niepetnosprawnościa, Oficyna Wydawnicza „Impuls”, Kraków 2013.

Buczel A., Samodzielność jako cecha osobowości, „Studia Philosophiae Christianae” 1993, nr 29(1).

Dąbrowski Z., Pedagogika opiekuńcza w zarysie, cz. 2, Wydawnictwo Wyższej Szkoły Pedagogicznej, Olsztyn 1995. 
Gajewska G., Pedagogika opiekuńcza i jej metodyka, Wydawnictwo Naukowe Uniwersytetu Zielonogórskiego, Zielona Góra 2004.

Kamińska U., Zranione dzieciństwo. Wychowankowie domu dziecka mówia, Wydawnictwo Naukowe „Śląsk”, Katowice 2000.

Kamińska U., Zarys metodyki pracy opiekuńczo-wychowawczej w rodzinnych i instytucjonalnych formach wychowania, Wydawnictwo Uniwersytetu Śląskiego, Katowice 2005.

Konstytucja Rzeczypospolitej Polskiej z dnia 2 kwietnia 1997 r. uchwalona przez Zgromadzenie Narodowe w dniu 2 kwietnia 1997 r., Dz.U. 1997, nr 78, poz. 483.

Konwencja o Prawach Dziecka przyjęta przez Zgromadzenie Ogólne Narodów Zjednoczonych 20 listopada 1989 r., Dz.U. 1991, nr 120, poz. 526.

Mańka J., Ornacka K., Trudne dzieciństwo i rodzicielstwo - wybrane aspekty funkcjonowania rodzin zastępczych $w$ Polsce $w$ perspektywie socjologicznej, [w:] A. Żukiewicz (red.), Rodzicielstwo zastepcze w perspektywie teoretycznej i praktycznej, Wydawnictwo Edukacyjne „Akapit”, Toruń 2011.

Maszke A.W., Metody i techniki badań pedagogicznych, Wydawnictwo Uniwersytetu Rzeszowskiego, Rzeszów 2008.

Motow I., Mielczarek M., Funkcjonowanie emocjonalne i społeczne wychowanków domów dziecka w aspekcie doznawanego sieroctwa społecznego, „Pedagogika Rodziny” 2018, nr 8(1).

Motow I., Motow-Czyż M., Proces usamodzielnienia wychowanków z zakładów resocjalizacyjnych, „Pedagogika Rodziny” 2015, nr 5(4).

Mudrecka I., Samodzielność, [w:] J.M. Śnieciński (red.), Encyklopedia pedagogiczna XXI wieku, t. 5, Wydawnictwo Akademickie Żak, Warszawa 2006.

Pilch T., Bauman T., Zasady badań pedagogicznych. Strategie ilościowe i jakościowe, Wydawnictwo Akademickie Żak, Warszawa 2001.

Ruszkiewicz D., Samodzielność życiowa dorostych córek nadopiekuńczych ojców, „Pedagogika Rodziny" 2018, nr 8(1).

Świrko-Pilipczuk J., Sytuacje edukacyjne podstawa procesu kształcenia i rozwijania samodzielności, [w:] K. Denek, F. Bereźnicki, J. Świrko-Pilipczuk (red.), Proces kształcenia i jego uwarunkowania, Agencja Wydawnicza „Kwadra”, Szczecin 2003.

Tomaszewski T., Z zagadnień psychologii samodzielności, „Kwartalnik Pedagogiczny” 1958, nr 1 .

Ustawa z dnia 25 lutego 1964 r. Kodeks rodzinny i opiekuńczy, Dz.U. 1964, nr 9, poz. 59.

Ustawa z dnia 9 czerwca 2011 r. o wspieraniu rodziny i systemie pieczy zastępczej, Dz.U. 2011, nr 149, poz. 887 z późn. zm.

Winiarski M., Rodzina - szkoła - środowisko lokalne. Problemy edukacji środowiskowej, Instytut Badań Edukacyjnych, Warszawa 2000.

Woźniak Z., Samodzielność życiowa osób z lekka i umiarkowana niepetnosprawnościa intelektualna $w$ świetle danych uzyskanych za pomoca nowego narzędzia pomiaru, „Niepełnosprawność i Rehabilitacja” 2017, nr 3.

Wyka A., Model badań przez wspólne doświadczanie, czyli o pewnej wersji empirii ,jakościowej”, „Kultura i Społeczeństwo” 1985, nr 2. 


\section{Streszczenie}

Przygotowanie do samodzielności życiowej usamodzielnianych wychowanków placówek opiekuńczo-wychowawczych

Celem artykułu jest próba odpowiedzi na pytanie, w jaki sposób placówki opiekuńczo-wychowawcze przygotowują swoich usamodzielnianych wychowanków do samodzielności życiowej. Problem został rozpatrzony z perspektyw przygotowania do samodzielności rodzinnej, zawodowej, społecznej i obywatelskiej. Zrealizowanie badań pozwoliło odpowiedzieć na pytanie, jak w badanych placówkach przebiega proces wychowawczy związany z przygotowaniem usamodzielnianych wychowanków do samodzielności życiowej oraz jakie w tym celu stosuje się metody i formy działań. Przystępując do projektu badawczego zrezygnowano z wcześniejszego stawienia hipotez, gdyż zgodnie z założeniami metodologicznymi zabieg ten jest niekonieczny w przypadku podejścia jakościowego. Praktyka ta w znaczny sposób mogłaby ograniczyć wartość poznawczą.

Słowa kluczowe: samodzielność, usamodzielnienie, placówka opiekuńczo-wychowawcza, dom dziecka, metody wychowawcze

\section{Summary \\ Preparation for independent living: Independent foster-child Care and Educational Institutions}

The aim of the article is to try to answer the question: how do care and educational institutions prepare their pupils for independence in life? The problem was considered from the perspective of preparations for family life, professional, social and civic independence. The research shed light on how the educational process in examined institutions related to the preparation of pupils for independent living and what methods and forms were used for this purpose.

Keywords: independence, empowerment, orphanage, children's home, educational methods 
Elżbieta Woźnicka (iD https://orcid.org/0000-0002-6505-1058 Akademia Humanistyczno-Ekonomiczna w Łodzi

\section{Niesłyszący nauczyciel w systemie edukacji - szanse i ograniczenia}

\section{Wstęp}

Zawód nauczyciela stał się obecnie zawodem bardzo popularnym. Liczne uczelnie przygotowują kandydatów do pełnienia tej roli. Stał się również dostępny dla osób z uszkodzonym słuchem, szczególnie dzięki dostosowaniu szkół do potrzeb osób niesłyszących oraz wprowadzeniu do uczelni wyższych tłumaczy języka migowego. Na zdobywanie wykształcenia wyższego przez osoby niesłyszące ma wpływ również rozwój ambicji edukacyjnych tej grupy społecznej. Pojawiła się grupa nauczycieli z wadą słuchu, którzy znajdują pracę głównie w szkołach i ośrodkach dla dzieci i młodzieży niesłyszącej lub słabosłyszącej, rzadko w oddziałach integracyjnych szkół ogólnodostępnych, a prawie w ogóle nie są zatrudniani w szkołach ogólnodostępnych dla dzieci i młodzieży słyszącej. Możemy więc przyjąć tezę, że nauczyciele z uszkodzonym słuchem to przede wszystkim surdopedagodzy, nauczyciele specjalni pracujący z dziećmi o specjalnych potrzebach edukacyjnych. Sami niejednokrotnie byli uczniami tego typu placówek i podopiecznymi w zdecydowanej większości słyszących nauczycieli. Kim jest surdopedagog? To specjalista zajmujący się uczeniem, terapią, diagnozowaniem i wspomaganiem rozwoju dzieci i młodzieży słabosłyszącej i niesłyszącej. Prowadzi zajęcia dydaktyczno-wychowawcze i opiekuńcze w: przedszkolach, szkołach podstawowych, gimnazjach, szkołach średnich i ośrodkach szkolno-wychowawczych dla dzieci niesłyszących i słabosłyszących. W swojej pracy posługuje się aparaturą słuchową, językiem migowym, korzysta z alfabetu palcowego oraz mowy dźwiękowej w celu opanowania przez uczniów wiadomości i umiejętności przewidzianych programem nauczania. Przygotowuje uczniów do pełnego uczestnictwa w życiu społecznym. Surdopedagog, jak każdy nauczyciel specjalny, powinien posiadać odpowiednie przygotowanie merytoryczne, kwalifikacje i kompetencje. Specyfika zawodu nauczyciela wymaga systematycznego podnoszenia i doskonalenia kwalifikacji 
zarówno zawodowych, jak i specjalistycznych związanych z wykonywaną pracą. Dlatego nauczyciel powinien uczestniczyć w procesie ciągłego doskonalenia, podnoszenia swoich kwalifikacji i rozwoju kompetencji.

\section{Kompetencje surdopedagoga}

W literaturze pedagogicznej podaje się wiele definicji dotyczących kompetencji oraz kwalifikacji nauczyciela. W kilku wybranych, między innymi w rozumieniu J. Pruchy ${ }^{1}$, kompetencje nauczyciela to zasób jego profesjonalnych umiejętności, wiedzy, wartości i postaw, którymi powinien dysponować każdy nauczyciel, aby mógł z sukcesami i efektywnie wykonywać swoją pracę. Z kolei J. Szempruch ${ }^{2}$ kompetencje definiuje jako zdolność i gotowość do wykonywania zadań na oczekiwanym poziomie, zgodnym ze standardami. Opisując kompetencje nauczycieli, wymienia się różne ich kategorie. Dotyczą one głównie: posiadanej wiedzy z zakresu nauczanego przedmiotu - tzw. kompetencje merytoryczne; umiejętności prowadzenia lekcji, nauczania i uczenia się, wykorzystania metod aktywizujących w swojej pracy, pobudzania ucznia do samodzielności - kompetencje dydaktyczno-metodyczne; znajomości i umiejętności wykorzystania sposobów oddziaływania na uczniów w klasie, rozwiązywania konfliktów i problemów społecznych, wsparcie ucznia w relacjach z rówieśnikami - kompetencje wychowawcze ${ }^{3}$. Według R.I. Arendsa skutecznie pracujący nauczyciel poza kompetencjami przedmiotowymi powinien posiadać wysokie kwalifikacje pedagogiczne, wśród których autor wyróżnia cztery grupy: 1) władanie zasobem wiedzy, na którym opiera się sztuka nauczania, 2) dysponowanie repertuarem najlepszych sposobów postępowania pedagogicznego, 3) wykazywanie postawy i umiejętności niezbędnych do systematycznej refleksji i rozwiązywania problemów, 4) rozumienie uczenia się i nauczania jako procesu ustawicznego ${ }^{4}$.

Nauczyciel pracujący z dziećmi i młodzieżą niesłysząca, słabosłyszącą, biorąc pod uwagę specyfikę pracy i trudności w osiąganiu sukcesów, powinien posiadać określone cechy osobowości, a w zasadzie nawet predyspozycje osobowościowe. W literaturze z zakresu pedagogiki specjalnej pojawia się wiele prac poświęconych cechom osobowości pedagoga specjalnego, w tym także surdopedagoga. Maria Grzegorzewska ${ }^{5}$, twórczyni pedagogiki specjalnej, opisuje osobowość pedagoga specjalnego jako efekt pracy samokształceniowej nad sobą. Pedagog specjalny powinien dbać o rozwój swojej struktury duchowej, rozwój

${ }^{1}$ J. Prucha, Pedeutologia, [w:] B. Śliwerski (red.), Pedagogika wobec edukacji, polityki oświatowej i badań naukowych, t. II, GWP, Gdańsk 2006, s 306, za: M. Kocoń, N. Malik, Kompetencje komunikacyjne surdopedagoga w zakresie języka migowego w opinii osób stabostyszących i głuchych, „,Rocznik Komisji Nauk Pedagogicznych" 2017, t. LXX, s. 102.

2 J. Szempruch, Kompetencje i zadania nauczyciela w procesie przeksztatcania szkoty, [w:] B. Muchacka (red.), Szkoła w nauce i praktyce edukacyjnej, t. I, Oficyna Wydawnicza „Impuls”, Kraków 2006, s. 230-231, za: M. Kocoń, N. Malik, dz. cyt., s. 103.

${ }^{3}$ M. Taraszkiewicz, Jak uczyć lepiej? Szkoła petna ludzi, Wydawnictwo Arka, Poznań 2001, s. 175.

${ }^{4}$ R.I. Arends, Uczymy się nauczać, WSiP, Warszawa 1994, s. 36.

${ }^{5}$ Zob. M. Grzegorzewska, Listy do młodego nauczyciela, Państwowe Zakłady Wydawnictw Szkolnych, Warszawa 1957; M. Grzegorzewska, Pedagogika specjalna, Państwowy Instytut Pedagogiki Specjalnej, Warszawa 1964. 
swojej indywidualności, pracować nad sobą, aby lepiej wykonywać swoje zawodowe obowiązki. Taka praca nad sobą według Grzegorzewskiej jest nieodłącznym elementem rozwoju osobowości pedagoga specjalnego. M. Grzegorzewska w swoich pracach, szczególnie w Listach do młodego nauczyciela, podkreśla, że zawód pedagoga specjalnego jest powołaniem do służby dziecku i jest to powołanie o niezwykle wysokiej godności. Dlatego pedagog specjalny powinien przez cały czas swojej pracy doskonalić siebie na drodze samokształcenia i samowychowania, doskonalić nie tylko swój warsztat pracy, ale także stosunek do wychowanka, rozwijać poczucie odpowiedzialności za swoją pracę i rozwój podopiecznych. Pedagoga specjalnego winny charakteryzować pozytywne postawy, takie jak:

1. Postawa akceptująca: pełna akceptacja dziecka takim, jakie jest ze swoimi niedoskonałościami, niesprawnościami, problemami natury intelektualnej oraz psychofizycznej. W relacjach z uczniem nauczyciel powinien okazywać pozytywne uczucia, traktować ucznia podmiotowo i indywidualnie.

2. Postawa opiekuńczo-integrująca: nauczyciel czuwa nad zaspokojeniem wszystkich podstawowych potrzeb wychowanka, jest dla niego wsparciem, opiekuje się nim, zaspokaja jego indywidualne potrzeby, dba o jego rozwój psychofizyczny. Jest wsparciem dla rodziców dziecka.

3. Postawa refleksyjno-badawcza: nauczyciel jest bacznym obserwatorem rozwoju ucznia. Posiada wiedzę pedagogiczną i psychologiczną, którą wykorzystuje w diagnozowaniu, obserwowaniu dziecka. Poprzez obserwacje dokonuje diagnozy i planuje proces rewalidacji, terapii wobec dziecka, aby jak najskuteczniej wpłynąć na jego rozwój.

4. Postawa wychowawczo-rewalidacyjna: nauczyciel wykorzystuje swoją wiedzę pedagogiczną i łączy ją z doświadczeniami z obserwacji dziecka, aby skutecznie wpłynąć na rozwój sfery psychicznej i kompensowanie deficytów rozwojowych dziecka.

W efekcie tych postaw uczeń ze specjalnymi potrzebami edukacyjnymi będzie czuł się bezpieczny, akceptowany nie tylko przez nauczyciela, ale i środowisko, przezwycięży niewiarę w swoje możliwości, poprawi się jego samopoczucie i pewność siebie. Wpłynie to na jego rozwój emocjonalny, poznawczy i społeczny.

Z kolei H. Borzyszkowska, definiując pedagoga specjalnego, wymieniła pewne normy moralne i warunki psychospołeczne, które powinien on spełniać:

1. Musi rozumieć wartość społeczną swojej pracy i charakteryzować się specjalnym stosunkiem do dziecka ze specjalnymi potrzebami edukacyjnymi. Powinien charakteryzować się racjonalną, profesjonalną umiejętnością organizowania opieki i wsparcia rewalidacyjnego.

2. Musi zrozumieć indywidualne problemy wychowanka i otoczyć go dużą troską, aby wprowadzić go na najbardziej odpowiednią dla niego drogę rewalidacji. Powinien być zatem dociekliwym i bardzo dobrym obserwatorem.

3. Musi być odpowiedzialny za cały planowany i organizowany proces dydaktyczno-wychowawczy. Musi ten proces zaplanować z uwzględnieniem indywidualności dziecka, jego potrzeb, niepełnosprawności. Aby zrealizować stawiane wobec dziecka zadania i cele, musi podejmować profesjonalną współpracę z różnymi specjalistami, rodziną, środowiskiem społecznym i umiejętnie ją organizować, jak również aranżować współpracę między tymi środowiskami. Niezbędna będzie umiejętność nawiązywania kontaktów z ludźmi. 
4. Musi go cechować zaufanie i przychylność wobec osób z niepełnosprawnościami. Jego zadaniem jest pobudzanie w nich wiary we własne siły i możliwości, rozwijanie ich podmiotowości i poczucia godności, człowieczeństwa. Niezbędne jest indywidualne podejście do ucznia oraz znajomość jego cech, predyspozycji, talentów.

5. Musi odznaczać się dużym optymizmem, pozytywnym stosunkiem do swojej pracy, do innych, nie tylko dziecka, ale również jego najbliższego środowiska - rodziny ${ }^{6}$.

Zawód pedagoga specjalnego jest bardzo trudny i złożony, ponieważ wymaga słuchania drugiego człowieka, uwrażliwienia na jego potrzeby, dyspozycyjności, cierpliwości i tolerancji. Wymaga zaangażowania w sprawy wychowanka, ponieważ często dotyczy sytuacji marginesowych, trudnych i intymnych. Jest też frustrujący, gdyż wymaga podejmowania trudnych decyzji lub respektowania decyzji innych, z którymi nie zawsze można się zgodzić.

W odniesieniu do nauczycieli pracujących w szkole dla dzieci i młodzieży z wadą słuchu należy powołać się na B. Szczepankowskiego, według którego nauczyciel - surdopedagog powinien specjalizować się w następujących obszarach: w dziedzinie surdopedagogiki, w nauczanym przez siebie przedmiocie, a także powinien posługiwać się językiem migowym. W Polsce dostępne są dwa sposoby komunikacji z osobami głuchymi. Pierwszym jest polski język migowy (PJM), a drugim system językowo-migany (SJM). PJM jest naturalnym językiem społeczności głuchych, powstałym na drodze rozwoju historycznego. Posiada własną, odrębną od języka polskiego gramatykę o charakterze wizualno-przestrzennym oraz leksykę. Badaniami nad jego strukturą zajmuje się obecnie w Polsce duży zespół specjalistów. Z kolei SJM jest kompilacją zasad gramatyki języka polskiego oraz znaków migowych zapożyczonych z PJM. SJM realizuje się symultanicznie za pomocą dwóch kodów - mówionego oraz miganego ${ }^{7}$.

Z kolei Katarzyna Plutecka wskazuje na cechy osobowości, które powinny charakteryzować współczesnego pedagoga pracującego z dziećmi z niepełnosprawnościami. Określa je w kategoriach paradygmatów:

- paradygmat człowieczeństwa,

- paradygmat autorytetu wyzwalającego,

- paradygmat samokształcenia,

- paradygmat poczucia odpowiedzialności,

- paradygmat samoaktualizacji.

Podstawą określania tych paradygmatów były dla autorki wskazówki M. Grzegorzewskiej ${ }^{8}$. Wymienione paradygmaty mogą być traktowane jako idealne, pożądane cechy

${ }^{6} \mathrm{Za}$ : A. Olszak, Psychopedagogiczne kompetencje nauczycieli szkót specjalnych, Wydawnictwo Uniwersytetu Marii Curie-Skłodowskiej, Lublin 2001, s. 61.

7 Za: M. Kocoń, N. Malik, dz. cyt., s. 103. Więcej na temat różnic miedzy PJM a SJM oraz badań nad polskim językiem migowym można zaleźć w pracach B. Szczepankowskiego oraz współczesnych badaczy PJM: P. Tomaszewskiego, M. Czajkowskiej-Kisil, P. Rutkowskiego, S. Łozińskiej i innych. Zob. B. Szczepankowski, Podstawy języka migowego, WSiP, Warszawa 1988; B. Szczepankowski, Język migany w szkole. Cz. 1, WSiP, Warszawa 1988; M. Czajkowska-Kisil, Gtusi, ich język i kultura - zarys problematyki, [w:] P. Rutkowski, S. Łozińska (red.), Lingwistyka przestrzeni i ruchu. Komunikacja migowa a metody korpusowe, Wydawnictwo Wydziału Polonistyki Uniwersytetu Warszawskiego, Warszawa 2014.

8 Zob. M. Grzegorzewska, Listy..., dz. cyt.; M. Grzegorzewska, Pedagogika ..., dz. cyt. 
współczesnego pedagoga specjalnego. K. Plutecka oprócz paradygmatów współczesnego pedagoga specjalnego wskazuje na szczególne kompetencje zawodowe surdopedagoga. Są one następujące:

- kompensacja prakseologiczna, czyli umiejętność właściwego planowania i organizowania pracy zawodowej, związana z przygotowaniem merytorycznym do wykonywania profesji nauczycielskiej o określonej specjalności, połączona z wiedzą specjalistyczną dotyczącą pracy z dzieckiem z wadą słuchu i jego rodzicami,

- kompetencja komunikacyjna, rozumiana jako umiejętność komunikacji z uczniami z wadą słuchu, umiejętność przekazywania i odbioru komunikatów, świadomość czynników zakłócających proces komunikacji językowej,

- kompetencja współdziałania, określona poprzez znajomość zasad i form współpracy nauczycieli i rodziców, rozumienia i akceptacji dziecka z wadą słuchu, umiejętność podejmowania właściwych działań pedagogicznych i rehabilitacyjnych wobec podopiecznych,

- kompetencja kreatywna, obejmująca wiedzę i umiejętności diagnozowania twórczych dyspozycji uczniów, rozwijania ich kreatywności, samodzielności myślenia, także dotycząca twórczości samego nauczyciela, czyli twórczego podejścia do wykonywanej pracy wychowawczej i dydaktycznej,

- kompetencja informatyczna, czyli umiejętność wykorzystania nowych technologii informacyjnych,

- kompetencja moralna, czyli odpowiednie dyspozycje psychiczne prowadzące do refleksji moralnej, etycznej oraz przygotowanie do działań zawodowych wynikających z profesji nauczycielskiej - mimo że wymieniona na końcu jest ona nadrzędna wobec pozostałych kompetencji ${ }^{9}$.

Wyznaczone paradygmaty pedeutologicznie jasno precyzują zadania współczesnego surdopedagoga. Dyskusyjny na pewno będzie uzyskiwany poziom poszczególnych kompetencji przez nauczycieli surdopedagogów, będzie zależny od indywidualnych predyspozycji i cech. Należy tylko mieć nadzieję, że dobór pedagogów do tego zawodu nie jest przypadkowy, a nauczyciel rozumie swoją powinność wobec niesłyszącego ucznia i stwarza mu warunki do rozwoju.

\section{Kompetencje niesłyszącego nauczyciela}

Osoby niesłyszące są szczególną kategorią surdopedagogów. Interesujące wydaje się poznanie ich swoistych dyspozycji osobowościowych jako kompetencji do pełnienia roli nauczyciela. Nieco inne cechy nauczyciela specjalnego podaje H. Strzyżewska ${ }^{10}$, które można potraktować jako zalety niesłyszącego nauczyciela. Zalicza do nich kompetencje

9 M. Zaborniak-Sobczak, Tożsamość pedagogów w kontekście wychowania do odpowiedzialności młodzieży $z$ wada stuchu. Szanse czy zagrożenia, „Annales Universitatis Maria Curie-Skłodowska” 2014, vol. XXVII, s. 34-35. Zob. też K. Plutecka, Kompetencje zawodowe surdopedagoga z wada stuchu, Oficyna Wydawnicza „Impuls”, Kraków 2006, s. 62-92.

${ }_{10}$ Zob. H. Strzyżewska, Kompetencje nauczycieli uczacych dzieci ze specjalnymi potrzebami edukacyjnymi, [w:] K. Ferenz, E. Kozioł (red.), Kompetencje nauczyciela wychowawcy, Wydawnictwo Uniwersytetu Zielonogórskiego, Zielona Góra 2002. 
emocjonalne, samoakceptację, komunikację, umiejętność rozwiązywania konfliktów. Kompetencje emocjonalne są szczególnie ważne dla procesu wychowania ucznia o specjalnych potrzebach edukacyjnych. Jest to umiejętność radzenia sobie ze swoimi uczuciami, akceptacja samego siebie ze swoimi pozytywnymi cechami, ale również z niedoskonałościami, a co za tym idzie - poprawna samoocena. Cechą osób niesłyszących jest umiejętność odczytywania emocji i mowy ciała. Nauczyciel niesłyszący sprawniej i precyzyjniej odczyta stan emocjonalny ucznia. Szczególnie w klasie powinien on lepiej poradzić sobie z opanowaniem negatywnych emocji ucznia i szybciej je dostrzec. Nauczyciel na co dzień posługujący się mową ciała, odczytywaniem emocji potrafi zapanować nad emocjami w klasie. Uczniowie poprzez obserwację nauczyciela uczą się odczytywania mowy ciała. Ponadto poprzez niewerbalne sygnały starają się nawiązać z nim kontakt, sami uczą się sygnalizowania swoich potrzeb poprzez niewerbalne sposoby komunikacji.

Kolejną istotną kompetencją jest samoakceptacja w odniesieniu zarówno do swoich mocnych stron, jak i niedoskonałości. Kompetentny nauczyciel dostrzega pozytywne cechy, aranżuje sytuacje i okazje, umożliwiające mu osiągnięcie sukcesu. Niesłyszący nauczyciel sam przeszedł trudną drogę poszukiwania swoich mocnych stron i akceptowania słabych stron, budowania własnego wizerunku, prawidłowej samooceny. Może być dla swoich uczniów, szczególnie niesłyszących, przykładem osoby o prawidłowej i pozytywnej samoocenie. Na niepełnosprawność dziecka może on spojrzeć z własnej perspektywy - osoby niesłyszącej - i dzięki temu jest w stanie wykazać się większym zrozumieniem. W porównaniu ze słyszącym nauczycielem będzie bardziej okazywał pozytywne uczucia i dostrzegał pozytywne aspekty bycia osobą głuchą czy niedosłyszącą. Może pomóc dziecku z wadą słuchu w zaakceptowaniu samego siebie. Dla rodziców dziecka niesłyszącego może być wsparciem i służyć pomocą w zrozumieniu potrzeb ich dziecka. Każdy nauczyciel w szkole specjalnej, pracując z niewielką grupą dzieci, prowadzi celową i zamierzoną obserwację dziecka, dotyczącą jego osiągnięć w sferze poznawczej, społecznej, psychofizycznej. Niesłyszący nauczyciel może prowadzić trafniejsze obserwacje, wiedząc, jakie konsekwencje w rozwoju zarówno psychofizycznym, jak i poznawczym ma ubytek słuchu. Może korzystać z własnych doświadczeń szkolnych i pomóc dziecku w zdobywaniu wiedzy. Rozumiejąc istotę deficytu, jakim jest ubytek słuchu, potrafi skuteczniej oddziaływać i pomóc dziecku w przezwyciężeniu braku wiary we własne możliwości intelektualne. Pomoże dziecku poprawić czy też uzyskać dobre samopoczucie, pewność siebie, poczucie własnej wartości. Może się to również przełożyć na poprawę stosunku do nauki i szkoły. Niesłyszący nauczyciel sam przeszedł kiedyś trudną drogę uczenia się, podążania za innymi, często odrzucenia czy dyskryminacji przez rówieśników.

Kompetencje komunikacyjne w przypadku komunikacji nauczyciela niesłyszącego z uczniami można rozpatrywać w różnych kategoriach. Nauczyciel jest dla ucznia wzorcem zachowań komunikacyjnych. Nauczyciel w klasie komunikuje się z uczniami poprzez przekazywanie treści przedmiotowych, omawianie zachowań itp., ale ważny jest także styl mówienia, gesty, mimika, mowa ciała. Relacje nauczyciela niesłyszącego z niesłyszącymi wychowankami charakteryzuje brak barier komunikacyjnych, komunikacja jest bardziej precyzyjna i partnerska dzięki znajomości języka migowego, zwłaszcza naturalnego języka 
migowego. W dobie propagowania edukacji dwujęzycznej jedynie nauczyciel głuchy jest w stanie przekazywać wiedzę za pomocą PJM. Niewielu nauczycieli słyszących potrafi perfekcyjnie opanować PJM. Problematyczny pozostaje sposób komunikacji z uczniami słyszącymi. W takiej sytuacji niesłyszący nauczyciel może w zależności od stopnia własnych umiejętności posługiwać się językiem polskim zarówno werbalnie, jak i pisemnie. Polski język migowy niewątpliwie wspiera proces nauczania i wychowania dzieci i młodzieży z wadą słuchu, jednak wciąż nie zyskał popularności wśród polskich nauczycieli surdopedagogów. Również doświadczenia nauczycieli z wykorzystaniem SJM, a nie PJM nie sprzyjają popularyzacji dwujęzyczności w nauczaniu dzieci i młodzieży z wadą słuchu. Z badań M. Kocoń i N. Malik ${ }^{11}$ wynika, że doświadczenia dorosłych już osób niesłyszących pokazują, iż nauczyciele komunikowali się z nimi głównie w języku polskim w mowie i piśmie. Natomiast potrzeby i oczekiwania badanych były takie, by surdopedagog porozumiewał się w polskim języku migowym. Analiza badań autorek wskazuje, że zdecydowana większość ( $90 \%$ badanych) była zdania, iż znajomość PJM w zawodzie surdopedagoga jest niezbędna. Badani wskazywali ponadto na potrzebę rozwoju przez surdopedagogów takich elementów warsztatu pracy nauczyciela, jak: rozpoznawanie i rozwiązywanie problemów, empatii, inteligencji emocjonalnej, biegłości w posługiwaniu się komputerem, uważnego słuchania oraz wyraźnej artykulacji. Wyniki badań autorek pokazują, że zdecydowana większość badanych jest zdania, iż nauczyciel w pracy z dziećmi i młodzieżą głuchą oraz słabosłyszącą powinien dysponować odpowiednimi kompetencjami komunikacyjnymi w zakresie posługiwania się PJM.

Zauważono, że respondenci porównywalnie wskazywali, iż surdopedagog oprócz komunikowania się z uczniami w PJM powinien również posługiwać się SJM oraz językiem polskim w mowie i w piśmie. Posługiwanie się PJM przez nauczycieli w opinii badanych wpływa na osiąganie przez nich lepszych efektów kształcenia. Zaprezentowane badania wskazują na potrzebę motywowania nauczycieli do podnoszenia swoich kompetencji komunikacyjnych, a w szczególności znajomości polskiego języka migowego.

Kolejną, istotną kompetencją w pracy nauczyciela surdopedagoga jest umiejętność rozwiązywania konfliktów i łagodzenia sporów. Klasa szkolna to miejsce, gdzie konflikty są rzeczą naturalną, taka jest specyfika kasy, szkoły i grupy rówieśniczej. Podłoże konfliktów i sporów może być bardzo różne, w przypadku uczniów z niepełnosprawnościami mogą to być indywidualne potrzeby i dążenia. W klasie, w której są uczniowie słyszący i niesłyszący, konflikty te wynikają niekiedy również z barier komunikacyjnych między uczniami. W rozumieniu konfliktu dla niesłyszącego nauczyciela znajomość PJM jest niewątpliwie pomocna. Może on dzięki temu bardziej precyzyjnie dotknąć istoty konfliktu, poznać jego podłoże. Może skuteczniej oddziaływać i wytłumaczyć trudne kwestie relacji rówieśniczych, zwłaszcza niesłyszącym wychowankom. Tym samym może wpłynąć na rozwój dojrzałości społecznej dziecka, jego rozwój emocjonalny i poznawczy.

Jakie inne cechy mogą być zaletami niesłyszących nauczycieli? Co wyróżnia osoby niesłyszące? Co mogłoby być ich atrybutem w pracy surdopedagoga? Nauczyciel niesłyszący identyfikujący się z tzw. kulturą głuchych pomoże uczniowi określić swoją tożsamość.

11 Zob. M. Kocoń, N. Malik, dz. cyt., s. 105-111. 
Będzie kształtował przynależność tożsamościową ucznia, w szczególności ucznia niesłyszącego. Pomoże mu w procesie kształtowania się jego tożsamości zarówno jednostkowej, jak i społecznej. Szczególnie tożsamość społeczna kształtuje się w odniesieniu do grupy jednostek o podobnych cechach. Szkoła dla dzieci niesłyszących jest odpowiednim miejscem do kształtowania się tożsamości, poszukiwania grupy odniesienia. Nauczyciel niesłyszący, pracujący w takim miejscu, może skutecznie pracować z uczniem nad poznawaniem i budowaniem jego tożsamości oraz poznawaniem specyfiki kultury głuchych.

Reasumując, nauczyciel niesłyszący posiada wiele cech osobowościowych, które w pracy pedagogicznej z dziećmi z ubytkiem słuchu stanowią jego atuty, a mianowicie:

- rozumie istotę pracy z dzieckiem niesłyszącym, szczególnie przez pryzmat własnego ubytku słuchu;

- rozumie wartość pracy nauczyciela dzięki swojemu doświadczeniu szkolnemu, a także aspiracjom edukacyjnym i zawodowym;

- rozumie wartość społeczną swojej pracy - pracuje na rzecz środowiska niesłyszących lub innych osób z niepełnosprawnościami (najczęściej nauczyciele niesłyszący zatrudnieni są w szkołach, ośrodkach dla dzieci i młodzieży z ubytkiem słuchu);

- rozumie problemy indywidualne ucznia wynikające z utraty słuchu, może indywidualnie otoczyć troską każdą jednostkę, aby kierować ją na odpowiednią drogę edukacji, rewalidacji;

- rozumie istotę wsparcia specjalistów - surdologopedów, surdopedagogów, terapeutów, gdyż sam w swoim życiu korzystał z ich pomocy i może dzielić się własnym doświadczeniem i wiedzą w tym zakresie; w wyborze drogi terapii może być wsparciem dla rodziców dziecka niesłyszącego;

- rozumie istotę rewalidacji przy pomocy aparatu słuchowego, implantu ślimakowego; zwłaszcza obecnie może być doradcą w sprawie zastosowania odpowiedniego protezowania - implantu bądź aparatu słuchowego; mając na uwadze obecne dylematy i dyskusje nad skutecznością tych urządzeń oraz procesu rewalidacji i nauki mowy wynikających z ich użycia, nauczyciel niesłyszący może być wiarygodnym i dobrym doradcą;

- rozumie potrzeby osób z niepełnosprawnością, gdyż sam zalicza się do tej grupy osób; rozumie potrzebę i konieczność rozwijania u swoich wychowanków wiary we własne możliwości; dzieci z uszkodzonym słuchem, mające poczucie niższości, mniejsze ambicje edukacyjne, zahamowania, frustracje, mogą uzyskać od niesłyszącego nauczyciela wsparcie w procesie rozwoju ambicji i wiary we własne możliwości;

- rozumie potrzeby osób niesłyszących, a zwłaszcza problemy z dyskryminacją, dostępem do tłumacza języka migowego i inne wynikające z niepełnosprawności, jaką jest ubytek słuchu; nauczyciel niesłyszący może być obrońcą osób niesłyszących, reprezentować ich potrzeby, a tym samym zapewnić poczucie bezpieczeństwa;

- rozumie istotę niepełnosprawności, jaką jest ubytek słuchu; pomimo niepełnosprawności odznacza się optymizmem, który może przekazywać swoim uczniom;

- wie, na czym polega istota kultury i tożsamości głuchych; może pomóc dzieciom i młodzieży z ubytkiem słuchu poznać i zrozumieć tę kulturę, a także w oparciu o nią budować własną tożsamość. 


\section{Trudności i bariery w pracy osób z uszkodzonym słuchem w charakterze nauczyciela}

Ludzie niesłyszący kompensują ubytek słuchu wzrokiem. Jest to niewątpliwie zaleta, jednak spostrzeżenia osoby głuchej mogą być niepełne, niedokładne. Skutkuje to często błędnym zrozumieniem i niepoprawną interpretacją obserwowanych zjawisk. Osoba niesłysząca odbiera głównie informacje wizualne, które nie zawsze bywają wyczerpujące i oczywiste. W zależności od stopnia ubytku słuchu trudności mogą pojawić się również przy spontanicznym rozumieniu mowy, co może mieć znaczenie w szkole, zwłaszcza w sytuacji zagrożenia czy niebezpieczeństwa. Mogą pojawiać się ograniczenia w rozumieniu komunikatów w różnych sytuacjach społecznych występujących w szkole i wymagających posługiwania się słuchem, na przykład uczestniczenia w zebraniach szkolnych, radach pedagogicznych, zebraniach z rodzicami, towarzyskich, organizacyjnych. Niezbędne wówczas jest wsparcie aparatu słuchowego lub tłumacza języka migowego. W przeciwnym razie nie wszystkie informacje będą dla nauczyciela zrozumiałe czy czytelne, zwłaszcza przy wypowiedziach kilku osób równocześnie. Maria Grzegorzewska ${ }^{12}$, pisząc o konsekwencjach utraty słuchu, podkreślała, że niesłyszący mają trudności w sferze poznawczej, wyobrażenia są zubożone i wówczas osoba niesłysząca zmuszona jest do kreowania wyobrażeń zastępczych, często nieprawdziwych. Te konsekwencje mogą mieć znaczenie w rozwoju zawodowym niesłyszącego nauczyciela: pogłębianiu wiedzy pedagogicznej, psychologicznej, doskonaleniu warsztatu pracy w oparciu o szkolenia, dyskusje.

Z kolei z badań A. Korzon ${ }^{13}$ wynika, że u osób głuchych mniejsze jest poczucie odpowiedzialności. Może to wynikać z ich sytuacji życiowej. Jako dzieci niesłyszące przez większość swojego życia byli objęci opieką innych: rodziców, nauczycieli, wychowawców w internacie, którzy za nich decydowali i w trosce o nich ograniczali ich samodzielność. W związku z izolacją społeczną w mniejszym zakresie niż u osób słyszących może być u nich rozwinięta umiejętność współpracy i współdziałania. Oczywiście jest to uwarunkowane indywidualnie również od predyspozycji osobowościowych i otwartości na kontakty z innymi. Według A. Korzon u osób niesłyszących mogą nie w pełni rozwinąć się takie cechy, jak: uczynność, życzliwość, chęć współdziałania. Przyczyny tego stanu mogą tkwić w procesie rozwoju dziecka niesłyszącego, powstałych w jego wyniku zaburzeniach rozwoju społecznego, emocjonalnego. Rzadziej u osób niesłyszących występuje chęć niesienia bezinteresownej pomocy, postawa altruistyczna. Mogą nawet wystąpić zaburzenia w sferze przyjaźni i koleżeństwa. U osób niesłyszących słabszy jest też rozwój aspiracji. Przyczyn tego stanu można upatrywać w warunkach środowiskowych, a także mimo wszystko jeszcze nie w pełni zadowalającym rozwoju szkolnictwa i w braku dostępu do tłumaczy PJM.

\footnotetext{
12 Zob. M. Grzegorzewska, Pedagogika..., dz. cyt.

13 A. Korzon (2001), Specyfika wzajemnej relacji nauczyciel-uczeń w procesie kształcenia dzieci niepetnosprawnych, [w:] Z. Palak (red.), Pedagogika specjalna w reformowanym ustroju edukacyjnym, Wydawnictwo Uniwersytetu Marii Curie-Skłodowskiej, Lublin 2001.
} 
Według autorki również aspiracje społeczne osób niesłyszących są zubożone. Nieliczni głusi działają w różnego rodzaju organizacjach społecznych, a jeżeli podejmują taką działalność, to głównie w Polskim Związku Głuchych. Dla nauczyciela niesłyszącego mało istotne może się wydawać funkcjonowanie w szkole organizacji społecznych czy też zasadność uczestniczenia w nich uczniów.

Osoby niesłyszące charakteryzuje ponadto niższy stopień rozwoju kulturalnego, który niewątpliwie jest konsekwencją ubytku słuchu. Brak słuchu ogranicza, a nawet uniemożliwia niektórym osobom odbiór treści akustycznych. Dla tej grupy osób mało dostępny jest język sztuki teatralnej czy dźwięk filmu. Osoby niesłyszące w związku z dominacją percepcji wzrokowej dostrzegają głównie cechy zewnętrzne, mają trudności w interpretacji i interioryzacji wartości wewnętrznych o wysokim stopniu abstrakcji, jakie niesie sztuka, literatura, muzyka. Ma to wpływ na małe zainteresowanie kulturą bądź ograniczenie się do kultury głuchych. W zawiązku z tym istnieje zagrożenie, że niesłyszący nauczyciel wśród swoich uczniów nie będzie rozwijał tej sfery aktywności. Może natomiast z sukcesem angażować niesłyszących podopiecznych w rozwój kultury głuchych. Proces uspołeczniania osób niesłyszących też przebiega w sposób specyficzny, szczególnie kontakty społeczne ze słyszącymi kolegami, rówieśnikami. Stosunek niesłyszących do świata słyszących charakteryzuje się dystansem. Jest to wynik trudności w porozumiewaniu się tych dwóch grup społecznych i wynikającej z tej sytuacji bariery psychologicznej. Konsekwencją tej sytuacji mogą być trudności w odnalezieniu się nauczycieli niesłyszących w sytuacjach społecznych w szkole. Czasami nauczyciel może czuć się tak jak uczeń niesłyszący niezrozumiany czy też odsunięty i izolowany od grona pedagogicznego.

\section{Podsumowanie}

Zadaniem współczesnego nauczyciela, czy to słyszącego, czy niesłyszącego, nie jest już tylko przekazywanie wiedzy. Jego aktywność traktowana jest bardzo szeroko, a zakres kompetencji jest ciągle rozszerzany, modyfikowany. Są mu stawiane coraz to nowe wyzwania, szczególnie w zakresie pracy nad wspomaganiem indywidualnego rozwoju jego uczniów, wychowanków. W związku z tym bardzo dużego znaczenia nabierają te kompetencje, które są związane z prawidłowymi relacjami interpersonalnymi, atmosferą w klasie, akceptacją ucznia, życzliwością wobec niego, podmiotowym traktowaniem, rozwojem jego kreatywności i potencjału. Wobec tych wyzwań staje również niesłyszący nauczyciel, który pomimo ubytku słuchu może z sukcesem realizować zadania surdopedagoga za sprawą rozwiniętych cech osobowościowych, a także umiejętności komunikacyjnych (znajomość PJM). W pracy z dziećmi niesłyszącymi nauczyciel z ubytkiem słuchu może być dla nich wsparciem, autorytetem i wzorem osobowym.

Niesłyszący nauczyciele w systemie edukacji to nowa kategoria nauczycieli, są to głównie surdopedagodzy, którzy w swojej pracy muszą się ciągle starać, aby sprostać stawianym im wymaganiom. Bardzo często, szczególnie w odniesieniu do swoich słyszących kolegów, mogą przejawiać poczucie niskiej wartości i brak wiary w możliwość osiągnięcia w pracy takiego sukcesu jak ich słyszący koledzy. Nie jest to uzasadniona obawa, zważyw- 
szy na sukcesy odnoszone przez niesłyszących nauczycieli zatrudnionych w ośrodkach w Warszawie, Łodzi czy Wrocławiu. Jednakże taka postawa może wynikać z doświadczeń szkolnych tych osób i ciągłej konieczności udowadniania swoich sukcesów. Brak kontaktu werbalnego może powodować poczucie samotności, nieuczestniczenia w życiu społecznym szkoły. Pomimo tych trudności, braku ofert pracy w szkolnictwie, ograniczeń miejsc pracy należy wspierać niesłyszących nauczycieli w ich drodze zawodowej oraz stwarzać warunki do zatrudnienia. Praca dla tej grupy osób ma z jednej strony oczywiste znaczenie ekonomiczne, ale z drugiej - jeszcze większą wartość społeczną i daje możliwość rozwoju i samorealizacji.

\section{Bibliografia}

Arends R.I., Uczymy się nauczać, WSiP, Warszawa 1994.

Czajkowska-Kisil M., Gtusi, ich język i kultura - zarys problematyki, [w:] P. Rutkowski, S. Łozińska (red.), Lingwistyka przestrzeni i ruchu. Komunikacja migowa a metody korpusowe, Wydawnictwo Wydziału Polonistyki Uniwersytetu Warszawskiego, Warszawa 2014.

Grzegorzewska M., Listy do młodego nauczyciela, Państwowe Zakłady Wydawnictw Szkolnych, Warszawa 1957.

Grzegorzewska M., Pedagogika specjalna, Państwowy Instytut Pedagogiki Specjalnej, Warszawa 1964.

Kocoń M., Malik N., Kompetencje komunikacyjne surdopedagoga w zakresie języka migowego w opinii osób stabostyszacych i głuchych, „Rocznik Komisji Nauk Pedagogicznych” 2017, t. LXX.

Korzon A., Specyfika wzajemnej relacji nauczyciel-uczeń w procesie kształcenia dzieci niepetnosprawnych, [w:] Z. Palak (red.), Pedagogika specjalna w reformowanym ustroju edukacyjnym, Wydawnictwo Uniwersytetu Marii Curie-Skłodowskiej, Lublin 2001.

Olszak A., Psychopedagogiczne kompetencje nauczycieli szkót specjalnych, Wydawnictwo Uniwersytetu Marii Curie-Skłodowskiej, Lublin 2001.

Plutecka K., Kompetencje zawodowe surdopedagoga z wada stuchu, Oficyna Wydawnicza „Impuls”, Kraków 2006.

Prucha J., Pedeutologia, [w:] B. Śliwerski (red.), Pedagogika wobec edukacji, polityki oświatowej i badań naukowych, t. II, GWP, Gdańsk 2006.

Strzyżewska M., Kompetencje nauczycieli uczacych dzieci ze specjalnymi potrzebami edukacyjnymi, [w:] K. Ferenz, E. Kozioł (red.), Kompetencje nauczyciela wychowawcy, Wydawnictwo Uniwersytetu Zielonogórskiego, Zielona Góra 2002.

Szczepankowski B., Język migany w szkole. Cz. 1, WSiP, Warszawa 1988.

Szczepankowski B., Niestyszacy - głusi - głuchoniemi. Wyrównywanie szans, WSiP, Warszawa 1999.

Szczepankowski B., Podstawy języka migowego, WSiP, Warszawa 1988.

Szempruch J., Kompetencje i zadania nauczyciela $w$ procesie przeksztatcania szkoty, [w:] B. Muchacka (red.), Szkoła w nauce i praktyce edukacyjnej, t. I, Oficyna Wydawnicza „Impuls", Kraków 2006. 
Taraszkiewicz M., Jak uczyć jeszcze lepiej! Szkoła pełna ludzi, Wydawnictwo Arka, Poznań 2001.

Tomaszewski P., Rosik P., Czy polski język migowy jest prawdziwym językiem?, [w:] Z. Tarkowski, G. Jastrzębowska (red.), Człowiek wobec ograniczeń. Niepetnosprawność, komunikacja, terapia, Fundacja Orator, Lublin 2002.

Zaborniak-Sobczak M., Tożsamość pedagogów w kontekście wychowania do odpowiedzialności młodzieży z wada stuchu. Szanse czy zagrożenia, „Annales Universitatis Maria Curie-Skłodowska” 2014, vol. XXVII.

\section{Streszczenie \\ Niesłyszący nauczyciel w systemie edukacji - szanse i ograniczenia}

Zawód nauczyciela stał się dostępny dla osób z uszkodzonym słuchem. Osoby niesłyszące podejmują studia pedagogiczne i chcą pracować w tym zawodzie. Na razie znajdują pracę głównie w szkołach dla dzieci niesłyszących i słabosłyszących. Artykuł omawia kompetencje, jakie powinien posiadać nauczyciel, z uwzględnieniem kompetencji pedagoga pracującego z dziećmi o specjalnych potrzebach edukacyjnych. Osoby niesłyszące same często przeszły drogę kształcenia i wychowania w szkołach dla dzieci niesłyszących, dlatego rozumieją potrzeby dzieci z wadą słuchu, potrafią zrozumieć ich sytuację, specyfikę rozwoju. Mogą pomóc im wejść w świat osób słyszących, a także poznać kulturę i tożsamość głuchych. Artykuł jest próbą pokazania zalet i ograniczeń, jakie mogą wynikać z ubytku słuchu, a które mogą mimo to być pozytywnymi cechami, przydatnymi w pracy z uczniem w szkole.

Słowa kluczowe: nauczyciel, głuchy, niesłyszący, słabosłyszący, surdopedagog, kompetencje nauczyciela, cechy osobowości nauczyciela

\section{Summary \\ Deaf teachers in the education system - opportunities and limitations}

The teaching profession has become accessible to people with hearing impairment. Deaf people undertake pedagogical studies and want to work in this profession. Nowadays, they mainly find employment in schools for deaf and hard of hearing children. The article discusses the competences of a teacher, with consideration given to the competence of a teacher educating children with special needs. Deaf people themselves attended schools for deaf and hard of hearing children so they know exactly what the needs of such children are. They are also able to understand deaf people's situation and the specificity of their development, help them to enter into the world of hearing people, as well as being familiar with the culture and identity of the deaf. This article is an attempt to show the advantages and limitations resulting from hearing loss in relation to the teaching profession.

Keywords: teacher, deaf, hard of hearing, surdopedagogue, teacher's competence, teacher's personality traits 


\section{Kreatywna edukacja. Dobre praktyki}

Otaczająca nas rzeczywistość rozwija się znacznie gwałtowniej niż w okresach minionych. Dlatego też oczywistą konstatacją jest stwierdzenie, iż przyszłość człowieka zależy od tego, czy zdobywana przez niego dzisiaj wiedza będzie aktualna, adekwatna i pomocna w rozwiązywaniu realnych problemów jutra. Jak powinna zatem wyglądać edukacja skierowana ku przyszłości? Jak przygotować człowieka do radzenia sobie z wyzwaniami późnej ponowoczesności?

Od początku 2017 roku wprowadzana jest w Polsce reforma oświaty, której główny cel to lepsze przygotowanie uczniów kończących cały cykl kształcenia do potrzeb rozwoju indywidualnego oraz potrzeb ponowoczesnego społeczeństwa i rynku pracy. Jej autorzy zauważają, że istotne jest nie tylko dbanie o równomierny rozwój wiedzy i umiejętności, ale także kształtowanie określonych kompetencji. Wyraźnie podkreśla się tutaj także rolę kompetencji, które można utożsamiać z kreatywnością. Widać to już na poziomie Rozporządzenia Ministra Edukacji Narodowej z dnia 14 lutego 2017 r. w sprawie podstawy programowej wychowania przedszkolnego oraz podstawy programowej kształcenia ogólnego dla szkoły podstawowej. Już we wstępie dotyczącym wychowania przedszkolnego czytamy: „Celem wychowania przedszkolnego jest wsparcie całościowego rozwoju dziecka. Wsparcie to realizowane jest przez proces opieki, wychowania i nauczania uczenia się, co umożliwia dziecku odkrywanie własnych możliwości, sensu działania oraz gromadzenie doświadczeń na drodze prowadzącej do prawdy, dobra i piękna"1. W części tegoż Rozporządzenia dotyczącej szkoły podstawowej jako jedna z głównych umiejętności, które mają być rozwijane w ramach kształcenia ogólnego wymieniane jest kreatywne

\footnotetext{
1 Rozporządzenie Ministra Edukacji Narodowej z dnia 14 lutego 2017 r. w sprawie podstawy programowej wychowania przedszkolnego oraz podstawy programowej kształcenia ogólnego dla szkoły podstawowej, w tym dla uczniów z niepełnosprawnością intelektualną w stopniu umiarkowanym lub znacznym, kształcenia ogólnego dla branżowej szkoły I stopnia, kształcenia ogólnego dla szkoły specjalnej przysposabiającej do pracy oraz kształcenia ogólnego dla szkoły policealnej, Dz.U. 2017, poz. 356, s. 2.
} 
rozwiązywanie problemów². Rola i znaczenie kreatywności eksponowane są następnie w Rozporządzeniu Ministra Edukacji Narodowej z dnia 30 stycznia 2018 r. w sprawie podstawy programowej kształcenia ogólnego dla liceum ogólnokształcącego, technikum oraz szkoły branżowej II stopnia. Jak czytamy, do najważniejszych umiejętności zdobywanych przez ucznia w trakcie kształcenia ogólnego w liceum ogólnokształcącym i technikum należą: kreatywne rozwiązywanie problemów z różnych dziedzin oraz łączenie zdolności krytycznego i logicznego myślenia z umiejętnościami wyobrażeniowo-twórczymi"3.

Jako efektywne narzędzie dydaktyczne mające sprzyjać rozwijaniu tych umiejętności i kompetencji wskazywana jest przez Ministerstwo Edukacji Narodowej metoda projektów - ,Zastosowanie metody projektu [...] pomaga również rozwijać u uczniów przedsiębiorczość i kreatywność oraz umożliwia stosowanie w procesie kształcenia innowacyjnych rozwiązań programowych, organizacyjnych lub metodycznych"4.

Co ciekawe, źródeł metody projektów można doszukiwać się już w XVI wieku, kiedy włoscy architekci doszli do wniosku, że nie należą do „stanu rzemieślników”, lecz do „stanu artystów". W związku z tym uznali oni, że wykształcenie murarskie oraz kamieniarskie, jakie otrzymywali ówcześni adepci architektury, jest niewystarczające do tworzenia pięknych, a zarazem użytecznych budowli - powinno być wzbogacone o studia z zakresu matematyki, historii, nauki o perspektywie i kompozycji. Dlatego też wraz z malarzami i rzeźbiarzami utworzyli w Rzymie w 1577 roku pierwszą nowożytną akademię sztuk pięknych: Accademia di San Luca. Kształcenie w tej akademii nie ograniczało się jednak do wykładów i warsztatów - istotnym novum były konkursy na zaprojektowanie kościoła, pałacu, gmachu użyteczności publicznej czy też grobowca. Dzięki owym projektom studenci mieli możliwość samodzielnego i twórczego zastosowania poznawanych podczas wykładów zasad. Wykonywanie projektów stało się z czasem stałym elementem kształcenia architektów w całej Europie i poza nią.

Znaczenie projektów zostało „na nowo odkryte” pod koniec XIX wieku w Stanach Zjednoczonych, gdzie za sprawą upowszechnienia praktycznego kształcenia technicznego wybuchła prawdziwa rewolucja techniczna, a nazwiska wynalazców (Alexander G. Bell, Thomas A. Edison, Nikola Tesla) przyćmiły nazwiska wybitnych przedstawicieli nauk ścisłych. Co więcej, projekty okazały się doskonale wpisywać się w amerykańską demokrację - wszak już Alexis de Tocqueville w swoim fundamentalnym dziele $O$ demokracji w Ameryce zastanawiał się nad kwestią, dlaczego Amerykanie przywiązują większą wagę do praktycznego zastosowania nauki niż teorii, i uznał nauki stosowane za w najwyższym stopniu demokratyczne. Stąd też Stillman H. Robinson ogłosił, że metoda projektów może być instrumentem wychowania „do demokracji” - poprzez nawiązanie do doświadczeń klas przemysłowych i produkujących wdraża studentów do samodzielności i współpracy, a ponadto stwarza tym najbardziej uzdolnionym szansę na społeczny awans, czyli realizację idei self-made mana.

2 Tamże, s. 12.

${ }^{3}$ Rozporządzenie Ministra Edukacji Narodowej z dnia 30 stycznia 2018 r. w sprawie podstawy programowej kształcenia ogólnego dla liceum ogólnokształcącego, technikum oraz szkoły branżowej II stopnia, Dz.U. 2018, poz. 467, s. 2-3.

${ }^{4}$ Rozporządzenie Ministra Edukacji Narodowej z dnia 14 lutego 2017 r., dz. cyt., s. 14. 
Najczęściej przyjmuje się, że termin metoda projektów (project method) został wprowadzony do słownika pedagogiki już w 1900 roku przez Charlesa R. Richardsa, który stosował go jednak wyłącznie w odniesieniu do praktycznego kształcenia technicznego amerykańskich nauczycieli prowadzących warsztaty. Szersze rozumienie metody projektów zaproponowali dopiero amerykańscy filozofowie pragmatyści: John Dewey, William James 5 . Stwierdzili oni, że wszelka działalność intelektualna powinna mieć na celu rozwiązywanie problemów, które powstają w toku naszych wysiłków radzenia sobie z tym, czego doświadczamy. Stąd też wymierna wartość tworzonych przez człowieka idei sprowadza się do tego, jak mogą one być wykorzystane.

W perspektywie pragmatyzmu w stosunku do każdej teorii (idei) możemy zapytać, co by się zmieniło, gdybyśmy w nią uwierzyli, oraz jakie konsekwencje miałoby to dla naszej działalności i życia, jeśli postępowalibyśmy zgodnie z tą teorią. Jak zauważał bowiem James, nasze teorie są narzędziami, których używamy, aby rozwiązać problemy wynikające $\mathrm{z}$ doświadczenia, a zatem powinny być oceniane w kategoriach sukcesu w wypełnianiu tego zadania. Jak pisze: „Cóż bowiem istotnego może pozostać ze sporów filozoficznych, jeśli różne systemy nie mają odmiennego wpływu na nasze działanie? A jeśli wszystkie zdania filozoficzne są pozbawione znaczenia praktycznego, to co za różnica, czy są one prawdziwe, czy fałszywe?"'.

Pragmatystyczne podejście do wszelkich teorii łączy się bowiem ze swoistym ujęciem prawdy. James rozwinął słynną koncepcję Charlesa S. Peirce’a, zgodnie z którą pełna koncepcja przedmiotu powinna uwzględniać wszelkie praktyczne skutki, które może on wywołać. W opublikowanym w 1907 roku Pragmatyzmie zauważa, że prawda nie jest zwierciadłem rzeczywistości, gdyż nie ma żadnego zwierciadła poza rzeczywistością - zarówno w porządku materialnym, jak i moralnym istnieją zawsze działania, instrumenty tych działań i abstrakcyjne idee wyrażające możliwość działania. Innymi słowy, prawdą jest to, co czemuś służy (skutecznie kieruje działaniem) - jedyną racją, która kieruje naszym uznaniem czegoś za prawdziwe, jest to, że się to sprawdza ${ }^{7}$. A zatem prawda nie jest czymś stałym i niezmiennym, wręcz przeciwnie - rozwija się w czasie. Kolejne teorie, idee mogą być potwierdzane lub mogą przestać być potwierdzane przez doświadczenie. Co więcej, o wartości takich teorii i idei świadczy przede wszystkim to, jakie konsekwencje pociąga za sobą uznanie ich za prawdziwe.

Podobne ujęcie nauki zaproponował Dewey, który stwierdził, że cała wiedza pełni jedynie funkcje instrumentalne - służy człowiekowi w przystosowaniu się do otaczającego go środowiska ${ }^{8}$. Punktem wyjścia była tutaj teoria Darwina, w ramach której ludzka myśl została zdefiniowana jako narzędzie w walce o byt. Właśnie dlatego Dewey na określenie własnej pozycji filozoficznej chętniej używał nazwy instrumentalizm, a nie pragmatyzm. W perspektywie instrumentalizmu myślenie jawi się jako narzędzie, które pozwala czło-

\footnotetext{
${ }^{5}$ Część historyków uznaje, że metoda projektów została stworzona przed trzystu laty przez europejskich profesorów szkół technicznych, skąd została przeniesiona do szkół średnich i elementarnych.

${ }^{6}$ W. James, Pojęcia filozoficzne a praktyczne wyniki, [w:] H. Buczyńska-Garewicz, James, Wiedza Powszechna, Warszawa 2001, s. 216.

7 Zob. W. James, Pragmatyzm, Książka i Wiedza, Warszawa 1957.

8 Zob. J. Dewey, Jak myślimy?, PWN, Warszawa 1988.
} 
wiekowi panować nad przyrodą i, co ważne, umożliwia „wzrost jednostki”. Myślenie jest środkiem do przyszłego działania - myśl (zwłaszcza myśl naukowa) jest instrumentem do rozwiązania problemów. W świetle instrumentalizmu nauka ma przestać być zawiła, niezrozumiała i zarazem małowartościowa dla codziennych, życiowych spraw.

Stąd w prowadzonej osobiście przez Deweya eksperymentalnej szkole Laboratory School of Chicago drogą rozwoju ucznia (wzrastania jednostki) stało się doświadczenie, czyli proces zdobywania poprzez człowieka wiedzy o świecie i samym sobie. Naczelną zasadą tak pojmowanego systemu dydaktycznego było „uczenie się przez działanie” w ramach różnorodnych zadań praktycznych. Według Deweya wychowanie nie może bowiem być redukowane do przekazywania informacji - powinno raczej organizować społeczny proces doświadczenia poprzez uczenie myślenia i moralnego postępowania ${ }^{9}$.

Jak zauważył Dewey, tradycyjna szkoła jest nastawiona na wtłaczanie uczniom ogromnej ilości teorii bez zapoznawania ze sposobami ich wykorzystania. Rodzi to sytuację, w której uczniowie są przepełnieni bezużyteczną wiedzą dotyczącą tego, co minione, a jednocześnie są nieprzygotowani do sprostania wyzwaniom przyszłości. Dlatego też, zgodnie z wyrosłą z instrumentalizmu edukacją progresywną, zamiast ćwiczyć ucznia w różnych dyscyplinach, powinno się go postawić w różnych sytuacjach, kiedy musi stworzyć metodę pokonania trudności, które się przed nim pojawiają.

Metoda projektów została na nowo zdefiniowana przez ucznia Deweya, akademickiego nauczyciela matematyki, Williama H. Kilpatricka. W szeroko dyskutowanej pracy The Project Method z 1918 roku stwierdził on, iż projekt to tyle, co: ,zamierzone działanie wykonywane z całego serca w środowisku społecznym" ${ }^{10}$. W takiej perspektywie uczniowie nie powinni zaczynać od zdobywania elementarnych wiadomości, które następnie byłyby organizowane w większe całości, ale odwrotnie - najpierw powinni sprawdzać teorie (wiadomości) i umiejętności w konkretnych sytuacjach społecznych, mających związek z ich codziennym życiem. Najważniejsze było w tym przypadku nie tyle praktyczne działanie czy też rozwiązywanie realnych problemów, co zamiar będący źródłem motywacji działania.

Kilpatrick okazał się ponadto niezwykle skutecznym propagatorem swojej koncepcjiprezentował ją podczas gościnnych wykładów kierowanych do nauczycieli i pedagogów, a także na rozprawach adresowanych do zagranicznych czytelników. Co więcej, we współpracy z uczniami i przyjaciółmi powołał do życia stowarzyszenie Project-Propaganda- Club, które wkrótce uległo przekształceniu w Project Method Societies. Promowało ono metodę projektów w całych Stanach Zjednoczonych - zajmowało się organizowaniem cyklicznych konferencji oraz publikowaniem czasopisma „Journal of Educational Method”.

Zainteresowanie metodą projektów w Polsce nie jest czymś całkowicie nowym. Po I wojnie światowej metoda projektów zaczęła zdobywać coraz większe uznanie poza Stanami Zjednoczonymi - w okresie międzywojennym zainteresowano się nią także w naszym kraju. Pierwszą książką poświęconą tej metodzie była dysertacja doktorska

${ }^{9}$ Zob. J. Dewey, Moje pedagogiczne credo, PWN, Warszawa 2005.

${ }^{10}$ W.H. Kilpatrick, cyt. za: M.S. Szymański, O metodzie projektów, Wydawnictwo Akademickie Żak, Warszawa 2010, s. 35. 
Johna A. Stevensona The Project Method of Teaching z 1920 roku, która ukazała się pod tytułem Metoda projektów w nauczaniu. Jak pisał w 1938 roku Bogdan Nawroczyński: „Z dużą pomysłowością i dobrym skutkiem stosowana jest w niektórych polskich szkołach średnich amerykańska metoda projektów jako urozmaicenie systematycznego w zasadzie nauczania i dobra sposobność do powiązania szkoły z życiem praktycznym. Zwróciła ona też na siebie uwagę wielu zwolenników szkoły twórczej" "11. Zainteresowanie metodą projektową zgasło w Polsce po II wojnie światowej - władza PRL nie zamierzała bowiem reformować szkoły, transformować gospodarki, a tym bardziej demokratyzować społeczeństwa.

Metoda projektów powraca dzisiaj w wielkim stylu. Zgodnie z przyjętymi w Polsce już w 2012 roku Europejskimi Standardami Edukacyjnymi implementowanie metody projektów do polskiego systemu edukacji to nie tylko zobowiązanie międzynarodowe, wynikające z realizacji założeń Deklaracji Bolońskiej oraz postanowień konferencji w Bergen z 2005 roku, w której udział wzięli ministrowie szkolnictwa wyższego z 46 krajów, ale także realizacja Zalecenia Parlamentu Europejskiego i Rady z dnia 23 kwietnia 2008 r.

Przykładem inicjatywy, która doskonale wpisuje się w naszkicowany wyżej nurt przemian, jest Przegląd Innowacji i Twórczości w Edukacji organizowany od pięciu lat przez Akademię Humanistyczno-Ekonomiczną w Łodzi. Przegląd ma formę konkursu, którego celem jest popularyzacja postawy twórczej wśród uczniów, nauczycieli oraz wyłonienie osób propagujących oraz implementujących innowacyjne, niestandardowe podejście do pracy dydaktyczno-wychowawczej. Konkurs ma charakter ogólnopolski i skierowany jest do uczniów, nauczycieli, metodyków, pedagogów szkół podstawowych, szkół ponadpodstawowych oraz tych wszystkich, którzy odpowiadają za innowacyjne procesy pojawiające się we współczesnej edukacji. Obejmuje on dwie kategorie: Kreatywny nauczyciel, pedagog, wychowawca oraz Innowacyjny projekt realizowany przez uczniów. Co ciekawe, zgłoszenia do konkursu w kategorii Kreatywny nauczyciel, pedagog, metodyk, innowator dokonują uczniowie danej szkoły, instytucji. Natomiast zgłoszenia w kategorii Innowacyjny projekt realizowany przez uczniów dokonuje nauczyciel koordynator.

Należy wyjaśnić, jak rozumiane w konkursie jest pojęcie Kreatywny nauczyciel, pedagog, wychowawca. Przede wszystkim dla organizatorów znaczenie mają niestandardowe metody w pracy z uczniami i oryginalne podejście do nauczania. Mogą być to innowacyjne i twórcze działania (dokonania) edukacyjne, współpraca z otoczeniem, czyli projekty implementowane na rzecz środowiska realizowane poza murami szkoły, a także konkretne działania mające związek z rozwijaniem pasji i zainteresowań uczniów. Jako szczególnie cenne są tutaj traktowane przykłady aktywizacji uczniów, inspiracje do podejmowania przez uczniów działań nowych i niestandardowych czy wspieranie aktywności w grupach defaworyzowanych, wykluczonych, potrzebujących wsparcia.

Kategoria Innowacyjny projekt realizowany przez uczniów wiąże się natomiast ze zgłaszaniem dokumentacji projektu, który był implementowany pod opieką nauczyciela w ramach procesu dydaktycznego (część pracy może być wykonana poza lekcjami). Znaczenie ma tutaj innowacyjność projektu, czyli konkretne przykłady działań niestan-

\footnotetext{
11 Tamże, s. 54-55.
} 
dardowych prowadzących do rozwiązania realnych problemów, zastosowanie ciekawego rozwiązania konkretnej sytuacji problemowej (edukacyjnej), niestandardowa aktywność na rzecz otoczenia społecznego lub szkoły.

Przegląd jest okazją do wzajemnej inspiracji, wymiany doświadczeń, zaprezentowania ciekawych rozwiązań dydaktycznych. Jako szczególna wartość jawi się tutaj jednak możliwość pokazania nie tylko pracy nauczyciela z uczniami, ale także pozwolenie uczniowi na podjęcie inicjatywy poprzez zgłoszenie kreatywnego nauczyciela czy pedagoga do konkursu. Ponadto w trakcie uroczystej gali Przeglądu istnieje możliwość zaprezentowania efektów aktywności projektowej bezpośrednio przez uczniów, których projekty zostały wybrane przez jury konkursu. To uczniowie są „,bohaterami” Przeglądu, kiedy przedstawiają swoje dokonania, dzielą się pomysłami na ciekawsze lekcje, ciekawszą szkołę czy zmiany, jakie chcą wprowadzać w otoczeniu szkolnym i pozaszkolnym. Poniżej przedstawię niektóre przykłady działań dydaktyczno-wychowawczych i projektów nagrodzonych w 2018 roku w V Przeglądzie Innowacji i Twórczości w Edukacji.

Na uwagę zasługują niewątpliwie wychowawcze działania laureata drugiej nagrody w kategorii Kreatywny nauczyciel, pedagog, metodyk, innowator - Marcina Kostyry, który prowadzi Teatr Moralnego Niepokoju w Młodzieżowym Ośrodku Wychowawczym nr 4 w Warszawie. Wychowawca resocjalizuje metodą teatru, który staje się tutaj poligonem doświadczeń dla specyficznego aktora. Aktor, czyli wychowanek gra nie tylko dla widza, gra przede wszystkim dla siebie. Nabywa wgląd w nieznaną sobie dotąd przestrzeń życia i zaczyna patrzeć na świat z perspektywy drugiego człowieka. Często jest to osoba, którą sam niegdyś mógł skrzywdzić. Wejście w rolę ofiary nie tylko otwiera na świat wartości, inspiruje do refleksji na temat dobra i zła, ale przede wszystkim zmusza do zadania sobie pytania, czy można żyć inaczej. Gra w teatrze dla wychowanków spełnia bardzo wiele funkcji: pozwala im podnieść samoocenę, pokazać się ludziom z dobrej strony, pokazać, że ma się jakiś talent, a dzięki temu ludzie mogą patrzeć na nich jak na utalentowanych młodych chłopaków, a nie na młodych bandziorów. Doskonale opisują ten efekt słowa kierowane przez Kostyrę do wychowanków: „chłopaki, chcę by o was pisali w gazetach, ale nie w kronice kryminalnej, tylko w kronice kulturalnej!”. Jednocześnie sztuka i teatr są tutaj traktowane jako „efekt uboczny”. Jak zauważa Kostyra - dużo ważniejsze rzeczy dzieją się przed wystawieniem spektaklu. Specyfiką teatru Kostyry jest to, że zawsze poruszany jest jakiś ważny społeczno-etyczny problem: wagary, asertywność, przemoc w rodzinie, alkoholizm rodziców, śmierć bliskich, porzucenie przez rodziców itp. Niestety są to też realne problemy podopiecznych z młodzieżowego ośrodka wychowawczego stanowiące w głównej mierze przyczyny ich niedostosowania społecznego. Dlatego też scenariusze są tutaj traktowane jako przyczynek do rozmów i do poruszania problemów głęboko ukrytych przed światem - pod osłoną fikcji teatralnej chłopcy niekiedy pierwszy raz w życiu mogą powiedzieć o swoim bólu i dzieciństwie.

Twórcze podejście do wykorzystania teatru odnajdujemy także w rewalidacji uczniów z dysfunkcją wzroku prowadzonej od lat przez Hannę Jastrzębską-Gzellę - zdobywczynię pierwszej nagrody w kategorii skierowanej do pedagogów. Laureatka jako metodę pracy wybrała dramę, ale wynikiem tak prowadzonych zajęć stał się teatr tworzony na indywidualne potrzeby uczniów lub potrzeby zespołów klasowych. Innymi słowy, zaobserwowane 
problemy zostały przełożone na pracę dramową, a ostatecznie na spektakl. Stworzona przez Jastrzębską-Gzellę Szkoła Dramy stała się miejscem twórczego działania w rolach, które sprzyja odkrywaniu wiedzy, rozwijaniu umiejętności społecznych uczniów, jak również kształtowaniu tożsamości i niepowtarzalności oraz pozytywnej samooceny dzieci i młodzieży. Szkoła Dramy jest również laboratorium praktykowania dramy dla samych nauczycieli - służy przygotowaniu animatorów i pedagogów dramy oraz upowszechnianiu dramy, pedagogiki teatralnej oraz organizacji warsztatów metodycznych kształtujących umiejętności dramowe, animacyjne, tutorskie nauczycieli. Podobną funkcję pełni założone przez laureatkę Stowarzyszenie Łódzka Akademia Dramy ŁAD, którego mentorką jest Halina Machulska.

Twórcza i zarazem doskonale wpisująca się w przywołaną we wstępie tego artykułu reformę jest niewątpliwie praktyka pedagogiczna Joanny Leszczyńskiej z gimnazjum Mikron w Łodzi - zdobywczyni trzeciej nagrody w kategorii konkursowej skierowanej do nauczycieli. Leszczyńska stosuje nieszablonowe metody kształcenia, wykorzystuje gry w procesie dydaktycznym, adaptuje nowoczesne technologie inspirujące twórcze myślenie uczniów, rozwija myślenie wizualne i różnorodne zainteresowania uczniów poprzez organizowane konkursy, udział w projektach, stosowanie różnorodnych środków dydaktycznych pozwalających na pobudzenie ciekawości poznawczej i wyobraźni uczniów. Przykładem takiej innowacji może być stosowanie w procesie dydaktycznym gamifikacji, czyli wykorzystanie gier w innych dziedzinach życia. Poprzez gamifikację uczniowie mogli zdobywać kolejne odznaki, punkty, medale, a przy okazji zwiększać swoją wiedzę oraz rozwijać umiejętności i kompetencje społeczne. Co istotne, mogli decydować o tym, w jaki sposób będą realizować cele edukacyjne. I tak w jednej z klas uczniowie zdobywają punkty (nazywane ,pożywką”, gdyż grywalizacja polega tutaj m.in. na hodowaniu bakterii w laboratorium), za które dostają karty do gry. Karty te mają nie tylko aspekt wizualny, ale zostały tak zaprojektowane, aby móc przy ich pomocy rozegrać prawdziwą karcianą grę. Opiera się ona na zasadach gry w wojnę - silniejsza karta pokonuje słabszą, a celem uczniów jest pokonanie jak największej liczby kart przeciwnika. Wprowadzenie gamifikacji do zajęć skutkuje zwiększeniem wewnętrznej motywacji do nauki. W efekcie uczniowie nie tyle muszą, co chcą się uczyć.

Najważniejszą kategorią konkursu realizowanego w ramach Przeglądu Innowacji i Twórczości w Edukacji jest kategoria skierowana do uczniów. Zgłoszone do niej w V edycji Przeglądu dokumentacje zrobiły wielkie wrażenie na jury i mogą napawać optymizmem wszystkich tych, dla których istotny jest kreatywny wymiar edukacji.

Laureatami pierwszej nagrody w tej kategorii zostali uczniowie XXIII LO w Łodzi, a opiekunem projektu był Jacek Malionowski. Produktem projektowym była realizacja cyklu krótkich filmów - rozmów wywiadów z byłymi pracownikami i z absolwentami szkoły. Pomysł projektu narodził się podczas organizacji święta patrona szkoły Józefa Tischnera w listopadzie 2017 roku, gdy uczniowie skonstatowali, iż zaniedbaniem byłoby nie utrwalić wówczas obecności w szkole Kazimierza Tischnera (brata Józefa), Szymona Wróbla - reżysera dokumentalisty czy Zbigniewa Wichłacza - operatora filmowego. Powstało wówczas kilka mniej lub bardziej udanych ujęć reporterskich, a apetyt na cały film wzrósł. Uczniowie zauważyli, że wśród absolwentów szkoły są postaci zaskakujące 
i niezwykłe, na przykład: twórca Teatru Stu, aktor i reżyser Krzysztof Jasiński; operator i dziekan Wydziału Operatorskiego Łódzkiej Filmówki Zbigniew Wichłacz; sprinter, reprezentant Polski na Igrzyskach Olimpijskich w Monachium w 1972 roku (nie wspominając o zmarłych Jerzym Grzegorzewskim czy Marku Frąckowiaku). Projekt ma charakter długofalowy, a jego podsumowanie planowane jest na rok 2020 - 75-lecie szkoły. Jednak jego realizacja składa się z kolejnych przygotowanych elementów - materiałów filmowych. Grupa doskonale trzyma się zarysowanego harmonogramu. Uczniowie pełnią role reporterów, operatorów, montażystów, researcherów, równocześnie ucząc się potrzebnych w tych rolach umiejętności.

Druga nagroda została przyznana za projekt zatytułowany ART. + Studio. Czyli jak się robi design w szkole i kim jest upiór na rowerze? Został on zrealizowany przez uczniów i absolwentów Gimnazjum nr 1 w Lęborku pod opieką Anny Rzepy i Barbary Cieślak. Wartością projektu było włączenie kreatywności uczniów w działania związane z ich codziennością oraz wykorzystanie przedmiotów użytkowych przy projektowaniu wnętrz, w których uczniowie często przebywają na terenie szkoły. Gimnazjaliści - inspirując się współczesną sztuką czystą i użytkową - projektowali, a następnie zmieniali wybrane pomieszczenia szkolne według własnych pomysłów, inicjatyw i potrzeb. Dzięki temu powstały ciekawe rozwiązania dotyczące organizacji przestrzeni - co istotne, zrealizowane za pomocą prostych środków i rozwiązań technicznych. Młodzi ludzie działali wprawdzie pod opieką nauczycieli, ale to oni samodzielnie określili przestrzeń, w której spędzają dużo czasu. Wykonując rzeczywiste projekty zmieniające ich otoczenie szkolne, nie tylko poszerzali swoje zainteresowania artystyczne związane ze współczesnym designem, ale ponadto wyrażali siebie, rozwijali wyobraźnię, kreatywność i wrażliwość estetyczną oraz kształtowali swoją codzienną rzeczywistość i sposób swojego funkcjonowania na terenie szkoły.

Laureatami trzeciej nagrody zostali uczniowie ze Szkoły Podstawowej nr 205 w Łodzi. W ramach projektu pt. Matematyka 100 lat temu koordynowanego przez Barbarę Pilas zaprosili na lekcję matematyki swoich rodziców i przenieśli ich w okres międzywojenny - wcielili się w postacie z wybranego okresu historycznego, nie tylko przebrali się w ich stroje z tego czasu, ale też rozwiązywali zadania matematyczne doskonale oddające specyfikę międzywojnia oraz wykorzystywali język szkolny z tamtej epoki. Działania projektowe pobudzały myślenie twórcze, pozwalały na pogłębienie relacji międzypokoleniowych oraz umożliwiały zrozumienie tego, jak zmieniło się nauczanie matematyki w czasie i jak wyglądała edukacja szkolna 100 lat temu. Ważnym aspektem projektu było stworzenie atmosfery z innej epoki - wywołanie możliwości symbolicznej „podróży w czasie”.

Podsumowując opisane działania nauczycieli, wychowawców i uczniów, należy podkreślić, że ich innowacyjny i twórczy charakter polega głównie na tym, że stwarzają one unikalną szansę do spojrzenia na rzeczywistość z innej, nowej perspektywy. Pozwalają wejść w nowe role, poznać lepiej siebie i zrozumieć potrzeby innych ludzi, ale także przekształcić codzienną rzeczywistość. Nagradzane w Przeglądzie innowacyjne działania nauczycieli i uczniów pozwalają dostrzec nowe możliwości obecne w edukacji oraz stymulują odbiorców tych projektów do zmiany postrzegania rzeczywistości - zachęcając do wyjścia poza schematy i znane rozwiązania. Tym samym nagrodzone inicjatywy doskonale wpisują się w przywołaną we wstępie reformę, w której akcentowane są konieczność 
rozwoju twórczego potencjału, pobudzanie tożsamości społecznej oraz rozwijanie szeroko pojmowanej przedsiębiorczości. Kreatywna edukacja to szansa na radość z wyzwalania pasji u siebie i innych, satysfakcja ze wspólnego zmieniania świata na lepszy, to w końcu taka relacja pomiędzy uczniem i nauczycielem, która umożliwia również rozwój tego drugiego. Wydaje się zatem, że kreatywną edukację warto budować poprzez podążanie za uczniem i bazowanie na jego potencjale i zainteresowaniach. W takiej perspektywie to potencjał uczniów stanowi fundament dla edukacji jutra, ale by ów potencjał nie został zabity, potrzebny jest kreatywny nauczyciel potrafiący motywować do poznawania świata.

\section{Bibliografia}

Dewey J., Jak myślimy?, PWN, Warszawa 1988.

Dewey J., Moje pedagogiczne credo, PWN, Warszawa 2005.

James W., Pragmatyzm, Książka i Wiedza, Warszawa 1957.

James W., Pojęcia filozoficzne a praktyczne wyniki, [w:] H. Buczyńska-Garewicz, James, Wiedza Powszechna, Warszawa 2001.

Rozporządzenie Ministra Edukacji Narodowej z dnia 14 lutego 2017 r. w sprawie podstawy programowej wychowania przedszkolnego oraz podstawy programowej kształcenia ogólnego dla szkoły podstawowej, w tym dla uczniów z niepełnosprawnością intelektualną w stopniu umiarkowanym lub znacznym, kształcenia ogólnego dla branżowej szkoły I stopnia, kształcenia ogólnego dla szkoły specjalnej przysposabiającej do pracy oraz kształcenia ogólnego dla szkoły policealnej, Dz.U. 2017, poz. 356.

Rozporządzenie Ministra Edukacji Narodowej z dnia 30 stycznia 2018 r. w sprawie podstawy programowej kształcenia ogólnego dla liceum ogólnokształcącego, technikum oraz szkoły branżowej II stopnia, Dz.U. 2018, poz. 467.

Szymański M.S., O metodzie projektów, Wydawnictwo Akademickie Żak, Warszawa 2010.

\section{Streszczenie \\ Kreatywna edukacja. Dobre praktyki}

Od początku 2017 roku wprowadzana jest w Polsce reforma oświaty, której główny cel to lepsze przygotowanie uczniów do potrzeb rozwoju indywidualnego oraz potrzeb ponowoczesnego społeczeństwa i rynku pracy. Stąd też coraz większy nacisk kładziony jest dzisiaj na przedsiębiorczość, kreatywność i innowacyjność. Przykładem inicjatywy, która doskonale wpisuje się w taki nurt przemian jest ogólnopolski Przegląd Innowacji i Twórczości w Edukacji organizowany od pięciu lat przez Akademię Humanistyczno-Ekonomiczną w Łodzi. W artykule zostały przedstawione wybrane osiągnięcia laureatów Przeglądu. Analiza tych przykładów wskazuje, iż kreatywna edukacja to nie tylko szansa na radość z wyzwalania pasji u siebie i innych, ale też satysfakcja ze wspólnego zmieniania świata na lepszy. W takiej perspektywie to potencjał uczniów stanowi fundament dla edukacji jutra. Słowa kluczowe: edukacja, kreatywna edukacja, reforma edukacji, metoda projektów 


\section{Summary \\ Creative education. Good practices}

From the beginning of 2017 education reform has been introduced in Poland. The main objective is to better prepare students for individual development and the needs of postmodern society and the labour market. Therefore, today, more and more emphasis is placed on entrepreneurship, creativity and innovation. An example of an initiative that perfectly fits into such a trend is the nationwide Review of Innovation and Creativity in Education organised for five years by the Academy of Humanities and Economics in Lodz. This article presents selected achievements of the laureates of the Review. Analysis of these examples indicates that creative education does not simply constitute the joy of freeing expression in oneself and others, but also provides the satisfaction of jointly changing the world for the better. From this perspective, the pupils' potential constitutes the foundation for tomorrow's education.

Keywords: education, creative education, education reform, project method 


\section{Znaczenie funkcji sołtysa we współczesnej Polsce}

Struktura każdego państwa ma ogromne znaczenie dla sprawnej jego działalności. Powinna przy tym brać pod uwagę przede wszystkim historię i położenie, ale też bazę gospodarczą dla stworzonych jednostek. Jednostki te muszą stać się dla społeczeństwa ich mikroojczyznami. Trzy zasady: samorządności, decentralizacji oraz pomocniczości, tworzą obecnie strukturę działalności samorządu terytorialnego w Polsce. Samorządność to zasada pozwalająca grupom społecznym podejmować suwerenne decyzje w kwestiach życia społecznego i problemów z nim związanych. Zasada decentralizacji ceduje na samorządy terytorialne maksymalną liczbę spraw niezwiązanych z ogółem społeczeństwa kraju. Natomiast zasada pomocniczości określa, iż państwo pomaga rozwiązywać sprawy i problemy, z którymi nie mogą poradzić sobie społeczności lokalne.

Sołtys jako jednostka pomocnicza samorządu terytorialnego na szczeblu gminy jest organem, który ma jedną z najdłuższych tradycji w polskiej historii. Od samego początku swego istnienia zajmował znaczącą rolę w życiu wiejskich społeczności, będąc lokalnym liderem oraz instytucją łączącą obywateli z władzą. Aktywny i kreatywny sołtys jest czynnikiem pobudzającym aktywność obywatelską w lokalnych społecznościach. Dlatego tak ważna w stymulowaniu społecznej aktywności jest świadomość mieszkańców, jakie miejsce w administracji publicznej zajmuje sołtys. Wyobrażenie ludzi na temat sołtysa często odbiega od rzeczywistości, jest to spowodowane w szczególności tym, że prawo w Polsce zmienia się gwałtownie przede wszystkim z powodu częstych, gdy spojrzymy na przekrój historyczny, zmian ustrojowych. Część mieszkańców ma przesadne wyobrażenie o uprawnieniach i przywilejach sołtysa.

\footnotetext{
1 Praca napisana pod kierunkiem prof. zw. dr. hab. Marka J. Malinowskiego.
} 
Celem pracy jest pogłębienie wiedzy o organie, jakim jest sołtys, co pozwoli zrozumieć społeczeństwu, jaką wśród nich pełni rolę. Główną tezą mojej pracy jest podkreślenie, że sołtys to niezbędna jednostka samorządu terytorialnego.

Najlepszym przykładem znaczenia funkcji sołtysa we współczesnej Polsce jest fundusz sołecki. Fundusz sołecki to wyodrębnione z budżetu gminy środki, o których zadysponowaniu decyduje sołectwo. O wyodrębnieniu funduszu sołeckiego w budżecie gminy postanawia już dwie trzecie gmin, mających na swoim terenie sołectwa. Tendencje te w szczególności zauważalne są w województwach opolskim, dolnośląskim i podkarpackim, czyli właśnie tam, gdzie jest rozpropagowany oddolny program odnowy wsi. Rozpowszechnienie funduszu sołeckiego obserwujemy tam, gdzie sołectwa mogą liczyć na dodatkowe wsparcie swoich przedsięwzięć z budżetu województwa na przykład w postaci różnych grantów dla sołectw, uczestniczących w organizowanych konkursach. Dobrym przykładem jest konkurs na najpiękniejszą wieś regionu. Istnieją również województwa, w których w nielicznych gminach działa fundusz. Pierwsze miejsce w tym niechlubnym rankingu zajmuje województwo mazowieckie z przewagą gmin wiejskich, które obejmują czasami kilkadziesiąt sołectw. To w tym województwie funkcjonuje ponad 20\% ogólnej liczby sołectw w Polsce².

Warto tutaj podkreślić rolę sołtysa, któremu najłatwiej jest zwołać zebranie wiejskie, jest on zatem osobą, która w opinii mieszkańców będzie odpowiedzialna za złożenie na ręce wójta odpowiedniego wniosku. Uchwalony wniosek powinien zawierać przedsięwzięcia wskazane do realizacji na terenie sołectwa w ramach zapowiedzianych środków.

Zdarza się również tak, że rada podejmuje uchwałę przeciwko funduszowi, ponieważ decyzję negatywną podjął już wcześniej wójt lub burmistrz. Widać to szczególnie, kiedy na sesji rady gminy brak jest dyskusji nad przygotowanym projektem przeciwko wydzieleniu funduszu sołeckiego w budżecie gminy. Dlatego bywa, że radni głosują za niewyodrębnianiem funduszu sołeckiego. W tym kontekście ważna jest rola sołtysów. Fundusz sołecki i jego zalety trzeba przybliżać nie tylko mieszkańcom, ale także radnym i władzom gmin. Doskonałym sposobem jest omawianie funduszu na spotkaniach sołeckich i gminnych, propagowanie go za pomocą ulotek i plakatów, za pośrednictwem forów dyskusyjnych w portalach internetowych, ale także na organizowanych szkoleniach. Od sołtysów zależy więc bardzo dużo. Wielu z sołtysów problem upatruje w braku zainteresowania zebraniem wiejskim, na którym ma być uchwalony wniosek o celowości kwoty przysługującej sołectwu z funduszu. Znaczące są informacje, jakie na ten temat przekazywane są mieszkańcom, oraz sposób, w jaki się tego dokonuje. Zawiadomienia o zebraniu muszą być zamieszczone w najczęściej uczęszczanych miejscach wsi. Muszą mieć atrakcyjną szatę graficzną i przede wszystkim wskazywać, jaka kwota przysługuje sołectwu do rozdzielenia i że to mieszkańcy zadecydują, na co ma być przeznaczona. Zebranie wiejskie, na którym uchwala się wniosek, należałoby poprzedzić spotkaniami informacyjnymi o funduszu sołeckim. Takie spotkania powinny dać mieszkańcom wyczerpującą wiedzę zarówno o funduszu, jak i celach, na jakie fundusz może i nie może być przeznaczony.

2 Znaczenie funkcji sołtysa we współczesnej PolsceR. Jałoszyński, Fundusz sołecki. Leksykon dobrych praktyk, Instytut Obywatelski, Warszawa 2017, s. 3. 
Dobre funkcjonowanie funduszu wymaga starań. Żeby realizacja przebiegała bezproblemowo, pracownicy urzędu, wójt czy burmistrz, a także sołtys muszą współpracować i być zaangażowani, by problemy związane z wymogami formalnymi nie zniechęciły żadnej ze stron do realizacji zaplanowanych działań.

Fundusz sołecki stanowi zaczątek ważnego procesu rozwoju wsi, który powinien być kontynuowany. Doświadczenie uczy, że odnowę wsi trzeba zaczynać od pierwszego, integrującego projektu. Jego sukces bowiem pozwoli przezwyciężyć trudności i ograniczenia w realizacji kolejnych projektów. Pokonanie podstawowych ograniczeń lokalnych mieszkańców wsi da możliwość dążenia do otwarcia i wyróżnienia się, a co za tym idzie, poszukiwania własnego wyjątkowego pomysłu na swoją wieś3

Trzeba zatem pamiętać, że przedsięwzięcia finansowane z funduszu sołeckiego aktywizują mieszkańców, gdyż niejako wymuszają na nich nieodpłatną pracę, która ma doprowadzić do pomyślnej realizacji planowanego przedsięwzięcia. Jeżeli gmina podejmuje odgórne decyzje i nie pozwala mieszkańcom decydować, często później bywa tak, że wzniesione bez udziału społeczności place zabaw, siłownie czy świetlice nie są wykorzystywane bądź niszczeją.

Samorządy w Polsce w 2016 roku wydzieliły we własnych budżetach łącznie $425 \mathrm{mln}$ złotych, przeznaczając je na zadania realizowane przez sołectwa. O ostatecznej korzyści przedsięwzięć sołeckich, na które gminy przekazały wydzielone środki pieniądze, będziemy mogli przekonać się za kilka lub kilkanaście lat. Już teraz nieocenioną korzyścią jest społeczna praca mieszkańców, pozyskane dla wsi darowizny i dotacje ${ }^{4}$.

Gminom, które realizowały swoje zadania, wykorzystując środki z funduszu sołeckiego, przyznawany jest zwrot części poniesionych nakładów, zatem jest to atrakcyjna forma realizowania inwestycji przez gminy. Niebanalna jest też kwota, rekompensaty części wydatków dla samorządów. Zwroty w roku 2017 osiągnęły pułap 130 mln złotych. Trzeba zwrócić uwagę, że również samorządy wojewódzki i powiatowe partycypują w korzyściach, które niesie ze sobą fundusz sołecki. Największym beneficjentem zmian dokonujących się za sprawą środków z funduszu sołeckiego jesteśmy jednak my sami jako społeczność lokalna. Dzięki realizowanym przedsięwzięciom zmienia się wieś i jej obraz chociażby dla mieszkańców miast, którzy chętnie korzystają z agroturystyki, stanowiącej atrakcyjny sposób na tani wypoczynek, a jednocześnie podtrzymującej tradycje i kulturę regionu. Widoczne są bardzo duże starania wsi zmierzające do tworzenia społeczeństwa obywatelskiego, w które dodatkowo włączane są kolejne pokolenia ${ }^{5}$.

Potrzeba wypełnienia wniosku o środki z funduszu pobudziła ludzi do działania, gdyż zaczęli oni zupełnie świadomie chcieć czegoś lepszego i nowego - a to jest konieczny pozytywny warunek zmiany ${ }^{6}$.

Na obszarach wiejskich skumulowały się zjawiska zawężające rozwój jej mieszkańców. Nadal mamy do czynienia z niedostatecznym poziomem wykształcenia, niedopasowaniem

\footnotetext{
3 R. Wilczyński, Fundusz sołecki-owoc i droga odnowy wsi, [w:] Fundusz sołecki-poradnik, Krajowe Stowarzyszenie Sołtysów oraz Instytut Obywatelski, Konin-Warszawa 2018, s. 9.

4 R. Jałoszyński, dz. cyt., s. 6.

5 Tamże.

${ }^{6}$ R. Wilczyński, dz. cyt., s. 8.
} 
kształcenia do potrzeb występujących na danym obszarze, zauważalne są niższe potrzeby życiowe, trudniejszy jest dostęp do rynku pracy, często spowodowany dużymi odległościami do miejsc oferujących zatrudnienie. Trwa proces zmian w sektorze wiejskim, dlatego uwaga musi się skupić na działającym tam kapitale ludzkim. Należy szkolić, doradzać, a także rozbudowywać i udostępniać całą infrastrukturę teleinformatyczną.

Sołtys wykonuje przede wszystkim zadania zapisane w statucie sołectwa. Niewiele przepisów prawa odnosi się do zadań i kompetencji sołtysa. Jedyny szczegółowy ich zakres można znaleźć w statucie danego sołectwa.

Dobry sołtys, by móc jak najlepiej wykonywać swoje obowiązki, powinien być opłacany (wynagradzany) z budżetu państwa. Obecne rozwiązania w poszczególnych gminach wymuszają, aby sołtys, szukając źródła utrzymania, angażował się w pracę zarobkową. Nie sprzyja to w żaden sposób rozwojowi wsi, a dodatkowo zabiera czas, który powinien być przeznaczony na różne inicjatywy integrujące mieszańców. Praca aktywnego sołtysa powinna być dla samorządu bezcenna.

Priorytetowym zadaniem sołtysa w Polsce jest integracja mieszkańców, jak również pobudzenie ich do współdziałania. Sołtysi muszą być podporami lokalnej społeczności. Ich pomysłowość i przedsiębiorczość pozwala załatwić wiele trudnych spraw. Fundusze sołeckie, którymi dysponują sołtysi, nie są wystarczające, by zaspokoić wszystkie potrzeby mieszkańców. Wielu z sołtysów wykazuje się ogromną kreatywnością, znajdując sponsorów czy organizując mieszkańców, dzięki czemu udaje się na przykład zbudować plac zabaw. Liderzy wiejscy pośredniczą między mieszkańcami a gminą. To za ich przyczyną na wyższych szczeblach władzy często zapadają kluczowe decyzje o ogromnym znaczeniu dla lokalnych społeczności - społeczności reprezentowanej właśnie przez sołtysów, do których jej członkowie zgłaszają swoje potrzeby. Dlatego też sołtysi powinni posiadać odpowiednią wiedzą na temat pozyskiwania środków zewnętrznych, aby móc finansować inicjatywy lokalne, umiejętnie aktywizować mieszkańców, mądrze współpracować z mieszkańcami czy to w pisaniu projektów, czy zakładaniu organizacji pozarządowych. Czego zatem życzyliby sobie sołtysi? Aby ich mieszkańcom „chciało się chcieć”, bo żaden sołtys nie jest w stanie sam wszystkiego zrealizować i nic tak nie aktywizuje mieszkańców jak urzeczywistnienie ich wizji.

\section{Bibliografia}

Balzer O., Chronologia najstarszych kształtów wsi słowiańskiej i polskiej, Lwów 1910.

Boć J., Pojęcie organu administracji publicznej, [w:] tegoż (red.), Prawo administracyjne, „Kolonia”, Wrocław 2007.

Gołębiowska A., Istota samorzadu terytorialnego w świetle postanowień Konstytucji Rzeczypospolitej Polskiej z dnia 2 kwietnia 1997 r., [w:] tejże (red.), Administracja publiczna: uwarunkowania prawne, organizacyjne i społeczne, Powszechne Wydawnictwo Prawnicze, Warszawa 2015.

Jałoszyński R., Fundusz sołecki. Leksykon dobrych praktyk, Instytut Obywatelski, Warszawa 2017. 
Szczypliński M., Organizacja, zadania i funkcjonowanie samorzadu terytorialnego, Wydawnictwo Dom Organizatora, Torun 2004.

Wilczyński R., Fundusz sołecki-owoc i droga odnowy wsi, [w:] Fundusz solecki-poradnik, Krajowe Stowarzyszenie Sołtysów oraz Instytut Obywatelski, Konin-Warszawa 2016. 


\section{Islamskie organizacje terrorystyczne na przykładzie Al-Kaidy i Państwa Islamskiego}

Powieść z gatunku political fiction pt. Dekret autorstwa Toma Clancy’ego, której pierwsze wydanie ukazało się w Polsce w 1996 roku, zaczynała się od sceny, jak zdesperowany pilot Boeinga 747 celowo uderza w gmach Kapitolu. Kryzys polityczny wywołany w strukturach rządowych Stanów Zjednoczonych Ameryki (United State of America, USA), w jednej chwili pozbawionej prawie wszystkich osób odpowiedzialnych za sprawne funkcjonowanie państwa, jest kanwą dalszej części snutej przez autora opowieści. Ta fantastyczna, wydawałoby się, wizja, w pewnym stopniu zrealizowała się 11 września 2001 roku, gdy pierwszy, a następnie kolejne z porwanych samolotów uderzyły w bliźniacze wieże Światowego Centrum Handlu (Word Trade Center, WTC) oraz gmach Departamentu Obrony USA (Pentagon) w Nowym Jorku. Szok i niedowierzanie opinii społecznej były tak duże, że z powątpiewaniem przyjmowano kolejne wiadomości z rekonstrukcji zdarzeń, a zaproszony jako komentator Clancy tłumaczył, że wizję skoordynowanego uderzenia w najżywotniejsze instytucje USA traktował jako absolutnie niemożliwą.

Niezwykle rzadko można być świadkiem lub uczestnikiem wydarzeń, które całkowicie zmieniają percepcję naszego postrzegania rzeczywistości. Przewroty cywilizacyjne, takie jak odkrycie ognia, zastosowanie koła, przewrót kopernikański, republikańska idea równości społecznej czy II wojna światowa jako wojna totalna, były impulsami, które przeniosły egzystencję i funkcjonowanie osób i państw na zupełnie nowy poziom.

Zamach na WTC rozpoczął nową erę wojny z międzynarodowym terroryzmem islamskim. Wiedza na temat pewnych procesów, zachowań jest niezbędna do podejmowania

\footnotetext{
1 Praca napisana pod kierunkiem prof. zw. dr. hab. Marka J. Malinowskiego.
} 
właściwych decyzji, zwłaszcza w sytuacjach krytycznych, gdy czas odgrywa decydującą rolę. Wybór tematu związanego z islamskim ekstremizmem podyktowany był więc chęcią pogłębienia własnej wiedzy związanej z „wojną z terroryzmem”. Nie bez znaczenia jest również fakt, że wojna ta nie została zakończona, a jej konsekwencji doświadczamy także w naszym kraju podczas tak prozaicznych czynności, jak planowanie wakacji czy wybór ubezpieczyciela.

Podstawowym celem pracy jest zbadanie związku pomiędzy religią muzułmańską a działalnością stricte polityczną, za jaką można uznać prowadzenie działań militarnych, nawet jeżeli będą to nieakceptowane przez międzynarodową społeczność akty terroru. Relacje między motywacją i zaangażowaniem religijnym a aktywnością na pozostałych obszarach działań są dla ludzi wychowanych w kulturze zachodniej niezrozumiałe i trudne do zaakceptowania.

Pojęcie terroryzmu islamskiego, które było przedmiotem badań niniejszej pracy, jest pojęciem niezwykle złożonym. Prosta analogia, która zmierza do równoległego traktowania dwóch wrogich sobie obecnie światów, a więc zsekularyzowanej kultury zachodniej i bliskowschodniej cywilizacji zbudowanej na fundamencie islamu, jest błędna. Krańcowo odmienna ewolucja ustrojowa, która dokonała się w obu kręgach kulturowych, sprawia, że odmienne znaczenia są przyporządkowane tak fundamentalnym pojęciom, jak sprawiedliwość, prawa obywatelskie, prawo, przestępstwo, obowiązek czy wiara. Odmienna hierarchia wartości i zasady funkcjonowania społecznego dodatkowo pogłębiają wzajemny rozdźwięk i niezrozumienie, a w wielu sytuacjach także oburzenie. Dodatkową komplikacją stał się fakt, że wewnątrz islamu istnieje wiele odłamów, koncepcji i frakcji, które są sobie wrogie i wzajemnie się zwalczają. Podobieństwa do Europy w czasach wojen religijnych po reformacji wydają sie tutaj naturalne. Organizacje terrorystyczne, które wyrosły na takim gruncie, wymykają się się tradycyjnym, historycznym kanonom, do których europejscy badacze są przyzwyczajeni.

Także w przypadku tej pracy największą trudnością było zrozumienie uwarunkowań religijnych, które w przypadku fundamentalistów islamskich porządkują i hierarchizują wszystkie podejmowane działania. W tak rozumianym kontekście kulturowym wszystkie kroki podejmowane przez Al-Kaidę (Baza, Sieć) i członków kalifatu wydają się zrozumiałe i logiczne, choć niewątpliwie dla każdego człowieka wychowanego w kulturze Zachodu - trudne do zaakceptowania.

Religia muzułmańska dzieli świat na dwa przeciwstawne obozy: świat islamu (Dar al-islam) i świat wojny (Dar al-harb), czyli przestrzeń, w której religia jest nieobecna, nieakceptowana albo nieznana. Konflikt pomiędzy dwoma światami jest przez muzułmanów postrzegany jako nieustanna wojna pomiędzy wierzącymi a niewiernymi. Teologia muzułmańska wyróżnia dwa dżihady: wielki, oznaczający codzienne zmagania z własnymi słabościami, grzechami, a którego celem jest większa gorliwość, oraz mały, który polega na obronie wiary i społeczności wierzących przed niewiernymi. Mały dżihad posługuje się dwoma środkami: pokojowymi są język i serce, druga droga posługuje się ręką i mieczem, jest więc siłowym ,nawracaniem” na prawdziwą wiarę w Proroka².

2 J. Piwowarski, J. Depo, P. Pajorski, Fundamentalizm islamski a terroryzm w XXI w., Wyższa Szkoła Bezpieczeństwa Publicznego i Indywidualnego Apeiron, Kraków 2015, s. 71-73. 
W tak rozumianej wizji świata i religii bardzo wiele zależy od indywidualnej interpretacji muzułmańskich autorytetów religijnych. Według wielu muzułmańskich teologów mały dżihad należy rozumieć defensywnie, tzn. zbrojne działania należy podejmować w razie konieczności obrony muzułmanów, ich wiary i terytoriów, jest to więc koncepcja podobna do europejskiej teorii wojny obronnej albo prawnej definicji obrony koniecznej. Stąd też wielu muzułmanów potępia wszelkie akty przemocy fundamentalistów. Jednocześnie dla fundamentalistów islamskich mały dżihad jest związany z obowiązkiem umacniania i rozpowszechniania islamu oraz zwalczania innowierców i heretyków ${ }^{3}$. Dżihadysta (arab. mudżahid), od konfliktu w Afganistanie mudżahedin, będzie osobą o skrajnie ekstremistycznych poglądach motywowanych radykalnym islamem, które będzie wprowadzał w życie, prowadząc dżihad. Poglądy opierają się na przekonaniu, że należy walczyć z niemuzułmanami, zwłaszcza z mieszkańcami Zachodu i Żydami oraz ustanowić państwo islamskie z obowiązującym prawem religijnym. Cel, jakim jest panowanie islamu, usprawiedliwia stosowanie przemocy, także w stosunku do ludności cywilnej oraz samych muzułmanów, którzy nie wypełniają obowiązku krzewienia islamu dość gorliwie ${ }^{4}$.

Idea światowego dżihadu, rozumianego jako globalna wojna o panowanie islamu, wywodzi się od muzułmańskich myślicieli przełomu XIX i XX wieku. To na ten okres datuje się założenie w Egipcie Stowarzyszenia Braci Muzułmańskich, które było pierwszą islamską organizacją fundamentalistyczną. Chociaż samo Dżama’at nie prowadziło działalności terrorystycznej, to wielu jej członków jest aktywistami organizacji terrorystycznych. Wszechstronna działalność społeczna Stowarzyszenia Braci Muzułmanów była ogromnym wsparciem dla ekstremistów islamskich, zwłaszcza w ostatnim czasie, gdy bractwo jako największa wtedy siła polityczna przejęło władzę w Egipcie w 2012 roku5

Współczesny terroryzm fundamentalistyczny będzie więc działaniem powszechnym, zarówno pojedynczych sprawców, jak i organizacji, których celem będzie spowodowanie maksymalnych szkód i ofiar. Chociaż stworzenie państwa islamskiego jest celem politycznym, to motywacja jest religijna - walka z grzechem i złem jako siły wrogiej islamowi ${ }^{6}$.

Ruch dżihadystyczny stworzony przez Usamę ibn Ladina należy więc traktować w kategoriach walki narodowo-wyzwoleńczej, w której narodem są islamscy ekstremiści, a celem politycznym przywrócenie ich dominującej pozycji w świecie. Ponieważ wiąże się to z podporządkowaniem wszystkich pozostałych nacji, narodów, religii i społeczeństw, mamy ponownie do czynienia z polaryzacją świata: z jednej strony świata Zachodu i jego dziedzictwa kulturowego, a z drugiej - muzułmańskich fundamentalistów różnych proweniencji zjednoczonych pod sztandarem Proroka. Traktowanie kolejnych muzułmańskich organizacji terrorystycznych jako grup anarchistycznych przekracza wszystko, co jest nam znane.

3 Tamże, s. 174-175.

${ }^{4}$ K. Górka-Sosnkowska, Zderadykalizować dżihadystę? Doświadczenia czterech państw muzutmańskich, „Roczniki Bezpieczeństwa Międzynarodowego” 2016, vol. 10, nr 2, s. 111.

5 A. Dzisiów-Szuszczykiewicz, Bliskowschodnia ,zimna wojna”, czyli saudyjsko-irańska rywalizacja w regionie w obliczu ,arabskiej wiosny”, „Bezpieczeństwo Narodowe” 2014, t. II, nr 30, s. 186-187.

${ }^{6} \mathrm{~K}$. Kubiak, W poszukiwaniu źródeł współczesnego terroryzmu. Między wiedzą a stereotypem, „Roczniki Bezpieczeństwa Międzynarodowego" 2007, vol. 2, s. 64. 
Al-Kaida i stowarzyszone z nią siatki ekstremistyczne bliższe są ponadnarodowym państwom czy też federacji, które jednoczy idea islamu. Jest to szczególnie widoczne podczas analizy struktury organizacyjnej, która przypomina rząd albo korporację, z podziałem na piony i obszary odpowiedzialności. Przekształcenie organizacji ibn Ladina w islamskie państwo jest wpisane w dwudziestoletni program działalności Al-Kaidy, dlatego też tworzenie struktur quasi-rządowych nie wydaje się niczym niezwykłym.

Państwo Islamskie (Islamic State, IS), na czele którego stoi Kalif, również swoją strukturą daje oznaki państwowości. Dwaj jego zastępcy sprawują władzę nad zajętymi terenami Iraku i Syrii. W kalifacie istniała dobrze wyszkolona armia, z mocną strukturą, zorganizowaną logistyką, wykształconym dowództwem. Powstały służby specjalne, system administracyjny, sądownictwa i propagandy. Finansowanie Państwa oparte było na sprzedaży ropy naftowej. IS miało rozwinięty system podatkowy oraz swoją walutę.

Utworzenie IS na terenie Iraku i Syrii nie udało się przede wszystkim z powodu agresywnie prowadzonej polityki, która prowadziła do szybkiego rozszerzania swoich granic, słabości organizacyjnej i administracyjnej oraz prowadzenia walk na wielu frontach równocześnie.

W procesie rekrutacyjnym ugrupowań islamskich można zauważyć w ostatnich latach tendencję do coraz liczniejszego udziału młodych muzułmanów urodzonych i wykształconych w krajach zachodnich. Młodzi, średnio liczący 25 lat mężczyźni, synowie emigrantów, często posiadający wyższe wykształcenie zdobyte na zachodnich uczelniach, bez kryminalnej przeszłości, o bardzo świeckich korzeniach, przeżywając kryzys tożsamości, znajdują ją w hasłach głoszonych przez islamskich radykałów. Możliwość identyfikacji z grupą jest tak istotna, że akceptują bez zastrzeżeń wymagania stawiane przez religijnych fundamentalistów i stają się bardzo aktywnymi działaczami, często podejmując się ataków samobójczych. Do tej grupy należeli wykonawcy zamachów z 11 września 2001 roku7.

Populistyczny obraz terrorysty jako człowieka ograniczonego, fanatyka czy wariata ma niewiele wspólnego z rzeczywistością. Analizując dostępne portrety psychologiczne, możemy wywnioskować, że członek organizacji terrorystycznej jest wysoce zmotywowanym, dobrze zorganizowanym i zasymilowanym ze środowiskiem profesjonalistą nastawionym na osiągnięcie założonych celów. Udział w organizacji zamachów weteranów walk partyzanckich, ekspracowników wywiadów odpowiedzialnych za bezpieczeństwo czyni z terrorystów bardzo trudnych i niebezpiecznych przeciwników dla, wydawałoby się, lepiej zorganizowanych, przygotowanych służb państwowych i międzynarodowych.

Nowe oblicze terroryzmu XXI wieku przejawia się przede wszystkim w symbiozie argumentacji politycznej i religijnej, które implikują wojnę nowego typu. Roszczenia islamistów nie dotyczą bowiem terytorium, a są próbą budowania porządku społecznego na fundamencie prawa religijnego, w którym koegzystencja różnych kultur i tradycji wydaje się niemożliwa ${ }^{8}$, również muzułmańska diaspora w Europie należy do najbardziej

${ }^{7}$ M. Adamczuk, M. Wróblewska-Łysiak, Ewolucja strategii i metod działania islamskich ugrupowań terrorystycznych i ich wpływ na bezpieczeństwo Polski, „Przegląd Bezpieczeństwa Narodowego” 2011, t. III, nr 19, s. 209-210.

${ }^{8}$ M. Stańczyk-Minkiewicz, Terroryzm - „zderzenie cywilizacji” czy ,,rozłam wewnątrzkulturowy”?, „Roczniki Bezpieczeństwa Międzynarodowego” 2007, vol. 2, s. 355-356. 
dynamicznie rozwijających się grup etnicznych i religijnych. Rosnąca emigracja, zarówno legalna, jak i nielegalna, wysoki poziom dzietności, zwłaszcza na tle tradycyjnych europejskich rodzin, niechęć do asymilacji z obcą i pogardzaną przez siebie kulturą Zachodu, a jednocześnie wysoka aktywność na polu społecznym i roszczeniowość znamionują rosnącą rolę muzułmanów w krajach Europy Zachodniej ${ }^{9}$.

\section{Bibliografia}

Adamczuk M., Wróblewska-Łysiak M., Ewolucja strategii i metod działania islamskich ugrupowań terrorystycznych i ich wpływ na bezpieczeństwo Polski, „Bezpieczeństwo Narodowe” 2011, t. III, nr 19.

Dzisiów-Szuszczykiewicz A., Bliskowschodnia „,zimna wojna”, czyli saudyjsko-irańska rywalizacja w regionie w obliczu ,, arabskiej wiosny”, „Bezpieczeństwo Narodowe” 2014, t. II, nr 30.

Górka-Sosnkowska K., Zderadykalizować dżihadystę? Doświadczenia czterech państw muzułmańskich, „Roczniki Bezpieczeństwa Międzynarodowego” 2016, vol. 10, nr 2.

Izak K., Zagrożenie terroryzmem w Europie na podstawie wybranych przykładów. Teraźniejszość, prognoza ewolucji i kierunki rozwoju, „Przegląd Bezpieczeństwa Narodowego” 2011, $\mathrm{nr} 5(3)$.

Kubiak K., W poszukiwaniu źródet współczesnego terroryzmu. Między wiedza a stereotypem, „Roczniki Bezpieczeństwa Międzynarodowego” 2007, vol. 2.

Piwowarski J., Depo J., Pajorski P., Fundamentalizm islamski a terroryzm w XXI w., Wyższa Szkoła Bezpieczeństwa Publicznego i Indywidualnego Apeiron, Kraków 2015.

Stańczyk-Minkiewicz M., Terroryzm - ,zderzenie cywilizacji” czy ,,rozłam wewnątrzkulturowy”?, „Roczniki Bezpieczeństwa Międzynarodowego” 2007, vol. 2.

9 K. Izak, Zagrożenie terroryzmem w Europie na podstawie wybranych przykładów. Teraźniejszość, prognoza ewolucji i kierunki rozwoju, „Przegląd Bezpieczeństwa Narodowego” 2011, nr 5(3), s. 121-122. 
Sebastian Szulc ${ }^{1}$

Akademia Humanistyczno-Ekonomiczna w Łodzi

\section{Nacjonalizm w przeszłości i czasach obecnych w Europie}

Przedmiotem pracy są zagadnienia związane z problematyką dotyczącą funkcjonowania jednego $z$ najbardziej znanych, a zarazem kontrowersyjnych nurtów polityczno-społecznych, jakim z pewnością jest nacjonalizm. Ze względu na dużą obszerność tematu celem pracy będzie obszar tzw. starego kontynentu, czyli Europy. To właśnie ona była kolebką wielu ruchów, partii, ugrupowań o trendach populistycznych i nacjonalistycznych. $\mathrm{Z}$ czasem wywarły one nieodwracalny wpływ na bieg wydarzeń. Trzeba jednak dodać, iż nacjonalizm z powodzeniem rozwijał się również na innych kontynentach.

Wielowymiarowość tematyki pracy wymusza zdecydowane wykroczenie poza ramy nauk o polityce i sięgnięcie po różne zagadnienia będące przedmiotem badań i zainteresowań dla tak wielu dziedzin, jak choćby historia, socjologia czy psychologia. Zapoznając się z powyższą pracą, czytelnik będzie stopniowo poruszać się w sferach różnych dziedzin wiedzy, co jest uzasadnione wymagającym charakterem tematu pracy, a przede wszystkim jego podmiotu. Poprzez szerszą analizę problematyki związanej z tym tematem uzyskano pełniejszy wymiar pracy, czego przykładem jest między innymi rys historyczny, w którym zwraca się uwagę na źródło podstawowego terminu. Wspomniane dziedziny naukowe będą się wzajemnie uzupełniać, tworząc przejrzyste tło dla całego opracowania, i w ten sposób nabierze ono pełniejszego wymiaru.

Na wybór tematu pracy istotny wpływ miały zainteresowania badawcze autora, które w bardzo dużym stopniu były skupione wokół zagadnień związanych z nacjonalizmem i sposobem, w jaki oddziaływał on na politykę oraz nastroje społeczne w poszczególnych krajach. Można to zaobserwować zwłaszcza w obecnych czasach, kiedy wzrasta słupek poparcia dla wszelkich ruchów o prawicowo-narodowej maści.

\footnotetext{
1 Praca napisana pod kierunkiem prof. zw. dr. hab. Marka J. Malinowskiego.
} 
Przyczyniły się do tego elementy wewnętrzne, takie jak: sytuacja polityczna, ekonomiczna czy społeczna oraz elementy zewnętrzne, na które złożył się całokształt determinantów i sytuacji mających wpływ na obraz sytuacji choćby w Europie Środkowo-Wschodniej².

Można z całą pewnością stwierdzić, że stare porzekadło mówiące, iż „historia zatacza koło", staje się w tym przypadku jak najbardziej aktualne. Jest to widoczne na przykładzie Niemiec z lat 30. ubiegłego wieku. Wówczas Adolf Hitler, opierając się na populizmie i antysemickich przesłankach, doszedł do władzy, wykorzystując krytyczną sytuację Niemiec, na którą złożył się kryzys ekonomiczny i ogólne niezadowolenie społeczeństwa niemieckiego wynikające z postanowień Traktatu Wersalskiego. Narodził się wtedy totalitarny system władzy, który cechował zarówno hitlerowską III Rzeszę, jak i stalinowski Związek Socjalistycznych Republik Radzieckich. Nie możemy pominąć także nacjonalistycznych nastrojów społecznych w takich krajach, jak Włochy, gdzie Benito Mussolini stanął na czele faszystowskiego rządu, oraz Hiszpania kierowana przez generała Francisca Franco. W obydwu przypadkach mamy do czynienia z modelowym autorytaryzmem, który charakteryzuje: ograniczony pluralizm przejawiający się głównie w systemie monopartyjnym, cechuje go również elitarność form działalności publicznej3. Powyższy obraz pokazuje, jak nacjonalizm przenosił się na inne kraje, wykorzystując podobne czynniki mające wpływ na jego powstanie, ale i ogólne tendencje i nastroje panujące w tym okresie w Europie, jak i na świecie.

To właśnie aktualność głównego podmiotu pracy stała się bezpośrednim impulsem do podjęcia tematu nacjonalizmu, którego piętno zmieniło losy niejednego z państw.

Główną hipotezą pracy jest wyartykułowanie, jak nacjonalizm wpływa i wpływał na życie wybranych narodów europejskich. Wymienię główne zagrożenia wynikające z szerzenia się tej ideologii. Pokażę, jak narody nie mogą sobie poradzić z demagogią nacjonalizmu i jak opisywana idea szerzy się najpierw w umysłach jednostek, by potem ogarnąć całe społeczeństwo. Wskażę również na elementy czyniące nacjonalizm popularnym wśród mas, takie jak spory i kontrowersje na tle terytorialnym i narodowościowym, gdyż bardzo często istotne problemy były zakorzenione w świadomości danego społeczeństwa i pochodziły z czasów bardziej odległych, a iskrą do wybuchu konfliktu stawały się spory graniczne. Innym elementem były uwarunkowania ekonomiczno-społeczne wpływające w dużym stopniu na rozwój nacjonalizmu w poszczególnych państwach. Można to było zaobserwować, patrząc na dzieje ludzkości, w których niejednokrotnie istotną przyczyną różnorakich zamieszek, przewrotów czy konfliktów był czynnik ekonomiczny ${ }^{4}$.

Przy pisaniu pracy opierałem się na następujących metodach badawczych: metodzie porównawczej, historycznej, monograficznej, ale i analizie treści dokumentów, artykułów, zdjęć. W pracy nie zabrakło również wielu innych technik badawczych, pomocnych przy pisaniu.

\footnotetext{
2 S. Wojciechowski, Nacjonalizm w Europie Środkowo-Wschodniej, „Atla 2”, Wrocław 1999, s. 135.

${ }^{3}$ K. A. Wojtaszczyk, Współczesne systemy polityczne, Wydawnictwa Szkolne i Pedagogiczne. Warszawa, 1992, s.35.

${ }^{4}$ S. Wojciechowski, op. cit., s. 93.
} 
Praca składa się z pięciu rozdziałów, które są odpowiednio podzielone na podrozdziały. W rozdziale pierwszym zdefiniowano pojęcie nacjonalizmu, tak aby czytelnik mógł zapoznać się z tematem pracy. Dokonano ponadto analizy nazwy omawianego słowa. Następnie przedstawiono zjawiska i pojęcia pokrewne wobec nacjonalizmu, takie jak: etnocentryzm, ksenofobia, szowinizm, rasizm, który zwłaszcza w ostatnim czasie coraz bardziej przybiera na sile. Przypomnijmy, że to właśnie prześladowania na tle rasowym były głównym filarem polityki nazistów, „Silnie oddziaływały na frazeologię faszystowską doktryny rasistowskie rzekomo dowodzące „misji” historycznej”, czyniąc przy tym całe zło, które doprowadziło do Holocaustu.

W rozdziale drugim skupiłem się na głównych nurtach nacjonalizmu w XIX wieku. Podjąłem temat nastrojów społecznych, które doprowadziły do wzrostu poparcia dla narodowych socjalistów w Niemczech oraz włoskich faszystów. Trzeci rozdział pracy poświęcony jest rozwojowi nacjonalizmu w dzisiejszej Europie oraz czynnikom, jakie wpłynęły na jego popularność. Rozdział czwarty jest zestawieniem najbardziej znanych i wpływowych ugrupowań politycznych w XXI wieku w Europie. Przedstawione zostały programy i poglądy przywódców najbardziej znanych europejskich partii, takich jak Fidesz, Swoboba czy Front Narodowy. Rozdział piąty pracy poświęcony został wpływowi nacjonalizmu na współczesną Europę, na jej społeczeństwo i rozwój. W szerszym stopniu została podjęta problematyka i konsekwencje rozprzestrzenienia się nacjonalizmu w systemie demokratycznym.

W pracy wykorzystano różnorodne źródła o charakterze interdyscyplinarnym Do tego celu wykorzystanych zostało wiele publikacji naukowych, w tym książek z różnych dziedzin naukowych, licznych artykułów prasowych (wywiady), strony internetowe, portale internetowe, media elektroniczne w postaci danych transmisji z takich stacji, jak: TVN, Polsat, Superstacja, TVP, Russia Today, BBC, Reuters. Jednym z głównych filarów bazy źródłowej pracy stały się słowniki naukowe różnych wydawnictw.

\section{Bibliografia}

Bartyzel J., Góra-Szopiński D., Nacjonalizm a konserwatyzm, Wydawnictwo Adam Marszałek, Toruń 2010.

Malendowicz P., W drodze do władzy... Nacjonalistyczne projekty państw Europy XXI wieku, Wąbrzeskie Zakłady Graficzne, Bydgoszcz-Wąbrzeźno 2017.

Sylwestrzak A., Historia doktryn politycznych i prawnych, Wydawnictwa Prawnicze PWN, Warszawa 1995.

Wojciechowski S., Nacjonalizm w Europie Środkowo-Wschodniej, „Atla 2”, Wrocław 1999.

Wojtaszczyk K.A., Współczesne systemy polityczne, WSiP, Warszawa 1992.

A. Sylwestrzak, Historia doktryn politycznych i prawnych, Wydawnictwa Prawnicze PWN, Warszawa 1995, s. 404. 
Edyta Pietrzak (D) https://orcid.org/0000-0003-1878-7545

Politechnika Łódzka

\section{Aldona Wiktorska-Święcka, Monika Klimowicz, Małgorzata Michalewska-Pawlak, Innowacje we współzarządzaniu rozwojem regionalnym. Praktyka instytucjonalna w wybranych regionach w Polsce}

Oficyna Wydawnicza Aspra, Warszawa-Wrocław 2017

Monografia jest efektem zainteresowań badawczych autorek dotyczących różnorodnych aspektów zarządzania obszarami wiejskimi, miastami i kapitałami: ludzkim, społecznym i intelektualnym, które to zainteresowania miały szansę ugruntować się, rozwinąć i skrystalizować w ramach badań innowacyjnych rozwiązań stosowanych w procesie współzarządzania rozwojem przez wybrane polskie regiony prowadzonych przez autorki w projekcie zatytułowanym Innowacje $w$ zarzadzaniu rozwojem regionalnym $w$ Polsce, finansowanym przez Narodowe Centrum Nauki. Fakt ten sam z siebie świadczy już o solidnym fundamencie merytorycznym projektu, jak i publikacji.

Już na wstępie należy zwrócić uwagę, że recenzowana pozycja ma charakter teoretyczno-empiryczny, co bardzo wyraźnie wpływa na jej kształt i charakter. Tematyka pracy obejmuje innowacyjne rozwiązania zarządcze w obszarze współrządzenia rozwojem regionalnym. Jak piszą autorki, „Innowacje to nieodłączny element dobrego rządzenia, gdyż ich celem jest podniesienie jego efektywności oraz przyczynianie się do generowania pozytywnych zmian w regionie" (s. 22). 
Uczone definiują rozwiązania innowacyjne wdrażane na poziomie regionalnym dla optymalizacji procesów zarządzania i osiągania celów regionów, identyfikują rozwiązania innowacyjne we współzarządzaniu rozwojem regionalnym, by określić mechanizmy przyczyniające się do ich tworzenia i implementacji, ustanawiają podstawę do analizy konsekwencji, jakie niesie wdrożenie innowacji z perspektywy zmian politycznych, społecznych i gospodarczych zachodzących w polskich regionach.

Zarys problematyki badawczej obejmuje teoretyczno-koncepcyjne i metodologiczne podstawy w postaci charakterystyki instytucjonalizmu, europeizacji i wielopoziomowego zarządzania. Zaprezentowane są w książce modelowe aspekty badania innowacji w zarządzaniu rozwojem regionalnym w postaci: podmiotów uczestniczących w opisywanych procesach, procesów decyzyjnych i efektów politycznych.

Celem przeprowadzonych badań było określenie i zrozumienie rozwiązań innowacyjnych stosowanych w procesie zarządzania regionami w Polsce, osiągnięcie strategicznych celów w postępującej decentralizacji władzy publicznej jako efektu procesów europeizacji oraz zdiagnozowanie przyczyn stosowania rozwiązań innowacyjnych przez polskie regiony. I z tego celu badaczki jak najbardziej się w publikacji wywiązują. Realizują go, stosując wiele perspektyw badawczych, poczynając od prawnej przez politologiczną, ekonomiczną, socjologiczną i czynią z niej przez to analizę interdyscyplinarną.

W rozdziale zawierającym koncepcje metodologiczne przedstawione są cztery hipotezy badawcze (1.Źródło innowacji w procesach zarządzania rozwojem regionalnym stanowią procesy europeizacji. Proces ten jawi się jako siła napędowa zmian społecznych, gospodarczych i kulturowych, ale także politycznych i instytucjonalnych i ma formalny, jak i nieformalny wpływ na funkcjonowanie administracji publicznej biorącej udział we współzarządzaniu regionalnym. 2. Wielopoziomowość procesów zarządzania rozwojem regionalnym w wariancie sieciowym i interaktywnym sprzyja generowaniu rozwiązań innowacyjnych przez procesy dyfuzji wiedzy i uczenie się zaangażowanych w nie podmiotów. 3. W zarządzaniu polskimi regionami innowacje mają charakter bardziej adaptacyjny niż pionierski, są wynikiem naśladownictwa. 4. Stosowanie rozwiązań innowacyjnych w zarządzaniu regionami wpływa pozytywnie na dynamikę rozwoju tych regionów. Oznacza to pozytywne zmiany i poprawę jakości życia mieszkańców). Hipotezy te podlegają weryfikacji w następnych rozdziałach. Znajduje się tam również metodologia prowadzonych badań wraz z wybranymi metodami i narzędziami oraz potencjał innowacyjny wybranych do badania województw.

Zaprezentowane teorie przyczyniły się do stworzenia modelu teoretycznego, który następnie został wykorzystany w badaniach empirycznych. Wszystkie te metody odnoszą się do trzech podjętych w pracy obszarów tematycznych, jakimi są zarządzanie obszarami wiejskimi, miastami oraz rozwój przedsiębiorczości.

Ze względu na przywoływany tu charakter pracy i obszar badaczy badania mają charakter multi- i interdyscyplinarny, co jest niewątpliwie ich wielką zaletą. Proces badawczy uwzględnia zatem wiele metod badawczych, w tym: analizę materiałów źródłowych, badanie studiów przypadku czy analizę instytucjonalną, a sam proces miał charakter indukcyjny. Badane były dokumenty i akty prawne, literatura naukowa, a równocześnie prowadzono badania jakościowe na poziomie regionalnym, które uzupełnione były badaniami na poziomie krajowym. 
Badaczki starannie przedstawiają i wprowadzają siatkę pojęć niezbędną do rozumienia i badania interdyscyplinarnego wszakże obszaru, jakim są innowacje we współzarządzaniu rozwojem regionalnym. Są to pojęcia i definicje rozwoju regionalnego, dobrego rządzenia (good governance), koncepcji współzarządzania (governance), współzarządzania rozwojem regionalnym (regional governance) i koncepcji zarządzania wielopoziomowego (multilevel governance), a także, co szczególnie istotne ze względu na cel niniejszej recenzji, koncepcji europeizacji jako kategorii analitycznej oraz koncepcji terytorialnego współzarządzania rozwojem regionu (territorial governance).

Obszar innowacji we współzarządzaniu rozwojem regionalnym zawarty jest w naukach o zarządzaniu, polityce, ekonomii i politykach publicznych i obejmuje innowacje we współzarządzaniu rozwojem regionalnym. Ze względu na brak istniejących definicji w badanym obszarze, choć w zakresie innowacji w zarządzaniu publicznym znaleźć można ich wiele (Anttiroiko i in. 2011; Bason 2010; Hartley 2005), autorki zaproponowały własną opisową definicję i stworzyły teoretyczno-empiryczną perspektywę w definiowaniu innowacji odwołującą się do takich cech innowacji, jak: partnerstwo, pozytywna zmiana, współpraca w aspekcie terytorialnym, a wszystko to z uwzględnieniem wyraźnego aspektu kontekstualnego opisywanych innowacji. Każdy z wymienionych tu elementów został szczegółowo opisany i uzasadniony.

Ze względu na teoretyczno-empiryczny charakter badań wykorzystano w nich schemat: teorie $\rightarrow$ modele $\rightarrow$ badania empiryczne. Na podstawie analizy materiałów źródłowych, wywiadów indywidualnych i badań fokusowych badaczki wyselekcjonowały trzy studia przypadków: działanie LEADER, zintegrowane inwestycje terytorialne ZIT oraz proces przedsiębiorczego odkrywania, będące przykładami innowacyjnych rozwiązań we współzarządzaniu regionem.

Źródła pozyskane w badaniach empirycznych pozyskane były za pomocą wywiadów indywidualnych i badań fokusowych przeprowadzonych z osobami zaangażowanymi w procesy współzarządzania regionami.

Monografia napisana jest bardzo rzetelnie i starannie. Przedstawiona w niej struktura jest przemyślana i logicznie uporządkowana. Praca składa się ze wstępu, sześciu rozdziałów z wyróżnionymi podrozdziałami oraz podsumowania w postaci przyczynku do teorii zmiany w procesach związanych z innowacjami we współzarządzaniu rozwojem regionalnym w Polsce, w sumie 250 stron.

Prezentowane w monografii zagadnienia odnoszą się do wiedzy z wielu dziedzin, dlatego można odnieść wrażenie, że poziom ich skomplikowania wymaga bardzo dokładnego i precyzyjnego zagłębiania się w podane informacje. Praca jest wymagająca dla czytelnika. Tym bardziej wymagająca była z pewnością dla jej autorek.

Przy całej pochwalnej ocenie monografii, uwzględniając oczywiście aktualność tematu i potrzebę badawczą, stwierdzić jednocześnie należy, że jest to potrzeba czysto utylitarna. Autorki książki same przyznają, że w polskim kontekście innowacje w zarządzaniu rozwojem regionów mają raczej charakter adaptacyjny niż pionierski. Taki też charakter mają prezentowane badania i publikacja.

Monografia przyczynia się do pogłębiania wiedzy w obszarze współzarządzania rozwojem regionalnym oraz stanowi inspirację dla badaczy zajmujących się tym tematem. 
Przeznaczona jest dla politologów, specjalistów od zarządzania publicznego, europeistów, ekonomistów, geografów oraz studentów nauk politycznych, administracji, europeistyki i zarządzania publicznego. 


\section{Inga B. Kuźma, Zucja Lange (red.), Mieszkanie i dom jako nieoczywistość kulturoworspołeczna}

Wydawnictwo LangeL - Łucja Lange, Łódź 2017

Monografia wieloautorska Mieszkanie i dom jako nieoczywistość kulturowo-społeczna pod redakcją Ingi B. Kuźmy i Łucji Lange wydana we współpracy zŁódzkim Partnerstwem Pomocy w sytuacji Wykluczenia i Bezdomności przez wydawnictwo LangeL - Łucja Lange, Łódź 2017, to pozycja o objętości 347 stron, składająca się ze wstępu, trzech części i aneksu zwierającego biogramy autorek i autorów.

Napisany przez Ingę B. Kuźmę wstęp wprowadza w kulisy przedsięwzięcia. Jest ono już drugą publikacją wydaną pod egidą Łódzkiego Partnerstwa Pomocy w sytuacji Wykluczenia i Bezdomności. Zawiera teksty kilkudziesięciu specjalistów wywodzących się z dziedzin, takich jak urbanistyka i planowanie przestrzenne, sztuka, socjologia, prawo, antropologia kulturowa, psychologia czy dziennikarstwo.

Celem publikacji jest przybliżenie szerokiej publiczności wiedzy teoretycznej w oparciu o sprawdzone lub nowatorskie metodologie, proponujące pogłębioną interpretację bezdomności i bezmieszkaniowości w rozmaitych ich odsłonach. Dlatego publikowane teksty mają prezentować efekty badań specjalistów wywodzących się z różnych dyscyplin. Książka jest forum wymiany doświadczeń wypracowywanych przez aktywistów i pracowników tych sektorów, które zajmują się osobami pozostającymi w kryzysie bezdomności.

Część I książki zatytułowana Planowanie i realizacja polityki mieszkaniowej $w$ wybranych kontekstach składa się z dziewięciu rozdziałów i zawiera teksty: Planistyczne uwarunkowania poprawy sytuacji mieszkaniowej autorstwa Tomasza Majdy; Najnowsze koncepcje rozwoju budownictwa mieszkaniowego dedykowanego osobom starszym i możliwości ich aplikacji na gruncie polskim napisany przez Paulinę Totę; Mieszkanie 
jako instrument rewitalizacji na przykładzie Łodzi, którego autorem jest przedstawiciel łódzkiego samorządu, Marcin Obijalski; Formy wsparcia osób przesiedlonych w ramach Programu Miasto Kamienic autorstwa Zofii Garus; Aktywne zamieszkiwanie i integracja: MiserArt, czyli , strefa kreatywna w labiryncie wykluczenia” napisany przez Magdalenę Zarębę; Model mieszkań społecznych w Kwilczu autorstwa Krystyny Dorsz; Pozytywna integracja społeczna - mieszkania treningowe dla młodzieży w kryzysie bezdomności Agnieszki Sikory; Integracja po francusku Łukasza Mazura oraz Kontenery. Instrukcja obstugi dla artystów autorstwa łódzkiej aktywistki, przedstawicielki ruchów miejskich, specjalistki od rewitalizacji i artystki Hanny Gill-Piątek. Są to teksty aktywistów, działaczy społecznych, planistów i analityków oraz urzędników lokalnych, czyli ludzi zajmujących się praktyczną realizacją polityk mieszkaniowych w różnych ich aspektach.

Składająca się z pięciu rozdziałów część II nosi tytuł Prawa lokatorskie w praktyce. Zawarte są w niej teksty: Czy Konstytucja RP gwarantuje jednostce prawo do mieszkania? Napisany przez Adama Ploszkę; Projekt nowelizacji ustawy o ochronie praw lokatorów - zastrzeżenia i postulaty Rzecznika Praw Obywatelskich Magdaleny Sobas; Standardy ochrony przed eksmisja na bruk - uwagi na gruncie Ustawy z dnia 21 czerwca 2001 r. o ochronie praw lokatorów, mieszkaniowym zasobie gminy i o zmianie Kodeksu cywilnego oraz rzadowego projektu jej zmian Dagmary Bobak i Agnieszki Jędrulak; Eksmisja - nieoczywiste oblicza problemu i możliwości jego rozwiązania autorstwa Beaty Kudlińskiej-Wodo, a także Wpływ reprywatyzacji na wykluczenie społeczne emerytów i emerytek Beaty Siemieniako. I tu jak już wskazują tytuły poszczególnych prac, głos został oddany prawnikom oraz ich interpretacjom ustaw i praw lokatorów.

Część III zatytułowana Bezdomność i bezmieszkaniowość jako wyzwanie zawiera sześć rozdziałów podejmujących temat bezdomności oraz towarzyszących jej postaw. Są to rozdziały: Stres, cierpienie i droga wyjścia z bezdomności. Prezentacja trzech projektów badawczych realizowanych w Instytucie Psychologii Uniwersytetu Opolskiego Anny Bokszczanin i Barbary Zmaczyńskiej; Bezdomność przestępcy (w świetle badań $i$ analizach socjologicznych i kryminologicznych) Andrzeja Kacprzaka; Rezyliencja $i$, bezmieszkaniowośc” bezdomnych rodzin na pograniczu polsko-niemieckim Rolanda Łukasiewicza; Lekcje wizualne. Metodyczno-metodologiczne glosarium na marginesie realizacji filmu o bezdomności autorstwa Pauliny Cichoń i Sebastiana Latochy oraz tekst Bezdomny czy jaki Oksany Hałatyn-Burdy i kończący tom Sensoryczny dom. Casus osób bezdomnych ze zwierzętami Łucji Lange.

Ze względu na różnorodność autorów i ich macierzystych dyscyplin oraz podejmowanych obszarów badawczych i praktyk społecznych całość pracy prezentuje wyniki oryginalnych badań zarówno o charakterze empirycznym, teoretycznym, jak i analitycznym przedstawiających obecny stan wiedzy na temat zamieszkiwania i bezdomności oraz ich kulturowych, prawnych i społecznych kontekstów.

Postawione w pracy, wymienione już tu cele, w tym cel etyczny ,,aby przez opis różnych praktyk i analizę zasad, na których się one opierają, ukazać konsekwencje traktowania nierówności i wykluczenia, w tym mieszkaniowego, jako stanu „,normalnego”, są wyraźnie określone i zrealizowane. 
Książka ma interesującą strukturę i, jak pisze redaktorka, ,zaczyna się od prezentacji wybranych praktyk społecznych, dopiero potem ukazane są podstawy prawne działań i polityk, natomiast podejście prawne jest istotne w tym tomie, stąd jego centralne miejsce”. W ostatniej części książki wracamy na poziom kolejnej, leczjuż innej praktyki społecznej. W części trzeciej następuje powrót w teren „w sensie etnograficznym”.

Publikacja zatem ciekawa pod względem metodologicznym, językowym oraz redakcyjnym. Podana przez autorów literatura przedmiotu jest reprezentatywna. Niejednokrotnie także autorzy poszczególnych rozdziałów podejmują z nią krytyczne dyskusje, co niewątpliwie podnosi walory publikacji, a zagadnienia przedstawione w poszczególnych rozdziałach czyni bardziej istotnymi pod względem naukowym. 


\section{Edyta Pietrzak (D) https://orcid.org/0000-0003-1878-7545}

Politechnika Łódzka

\section{Joanna Sośnicka (red.), Inżynier $z$ duszą humanisty}

Wydawnictwo Politechniki Łódzkiej, Łódź 2017

Książka Inżynier z dusza humanisty. Miejsce i rola problematyki humanistycznej $w$ dyskursie politechnicznym zredagowana przez Joannę Sośnicką podejmuje temat niezwykle aktualny, ważny, aczkolwiek wciąż niedoceniany na tyle, na ile zasługuje, a mianowicie miejsce nauk humanistycznych i społecznych w badaniach z zakresu nauk technicznych oraz procesie kształcenia politechnicznego.

Technologie nie istnieją wszak w próżni, ale tworzone są przez człowieka i człowiekowi mają służyć. Ludzie wchodzą więc z nimi w interakcje i odczuwają na sobie oraz w społeczeństwie konsekwencje ich działania. Implementacja technologii, a także ich dysymilacja nie jest możliwa bez uwzględnienia kontekstu ludzkiego i społecznego. Ponadto, by zrozumieć dzisiejszy świat, oparty na złożoności i transdyscyplinarności trzeba czerpać w wielości możliwości, jakie daje współczesna nauka, a tym samym rozwijać w dzisiejszych studentach, a przyszłej inteligencji podejście intersekcjonalne. I takie jest właśnie podejście redaktorki oraz autorów poszczególnych zawartych w tomie tekstów. Dlatego gratuluję dostrzeżenia i podjęcia w badaniach tematu istotnego i wymagającego konsekwentnego namysłu.

Praca liczy 390 stron, jej struktura oparta jest na wstępie i trzech rozdziałach. We wstępie pomysłodawczyni tomu i jego redaktorka przedstawia główną ideę przygotowania publikacji i odwołuje się do będącego inspiracją dla redaktorki dzieła prof. Marii Stolarskiej Technik z dusza humanisty, która podejmowała podobne zagadnienia przed dwudziestu laty. Wprowadzenie to poparte jest zresztą wspomnianym artykułem przedrukowanym z ,Forum Akademickiego”, nr 11(1999).

Rozdział pierwszy przedłożonej do recenzji książki zatytułowany Technika a humanistyka zawiera pięć artykułów podejmujących zagadnienia ogólne i wprowadzające 
w temat. Otwiera go artykuł Józefa Lubacza polemizujący przekornie z tytułem całej publikacji. Następne teksty: Andrzeja Kiepasa, Romana Batko, Grzegorza Ostasza i Romana Morawskiego podejmują problem relacji humanistyki z techniką, w tym na przykład problem tworzenia laboratoriów technohumanistyki i potrzeby łączenia dyscyplin pozornie uznawanych za odległe.

Rozdział drugi zatytułowany Humanistyczne aspekty inżynierii składa się z sześciu artykułów. Podejmuje zagadnienia związane z etycznym wymiarem zawodu inżyniera w tekstach Ryszarda Tadeusiewicza i Marka Sikory, profesjonalizmie zawodowym w tekście Ewy Hoppe czy programowania procesu kształcenia Wojciecha Gasparskiego, bardzo istotnego zagadnienia odpowiedzialności, a także opisanego przez Ewę Hyży miejsca płci w badaniach i edukacji technicznej.

Rozdział trzeci, noszący tytuł Humanistyka w edukacji i nauce, złożony jest z ośmiu tekstów podejmujących zagadnienia edukacji humanistycznej na studiach technicznych oraz przedstawiających dobre praktyki w tej dziedzinie, jak na przykład w tekście Marii Kalczyńskiej z Politechniki Opolskiej. Podejmuje też kwestie kreatywności opisanej przez Halinę Rarot, edukacji globalnej podjętej przez Helenę Ciążelę i Pawła Bernata,jak również sztucznej inteligencji w artykule Krystyny Górniak-Kocikowskiej. Zadaje pytanie „,dokąd zmierzamy”, jak w tekście Andrzeja Kraśniewskiego czy odwołuje się do zadań, jakie powinna podejmować uczelnia wyższa w procesie kształcenia humanistycznego oraz profilu absolwenta w tekście Ewy Chmieleckiej.

Całość pracy, mimo interdyscyplinarnych korzeni autorów poszczególnych podrozdziałów, związana jest wspólną ideą oraz wyraźnym poparciem autorów dla jej istotności. Dlatego książka, choć różnorodna dyscyplinarnie, jest bardzo spójna. Ma na to wpływ także dobór zaproszonych do publikacji autorów, będących specjalistami w swoich dziedzinach, a jednocześnie mających doświadczenie w zakresie kształcenia humanistycznego oferowanego na kierunkach niehumanistycznych.

Recenzowana praca jest cenną propozycją podjęcia tematu relacji nauk humanistycznych i technicznych nie tylko dla przedstawicieli tych nauk, ale również dla szerokiego grona czytelników zainteresowanych kondycją współczesnej edukacji. Mam nadzieję, że stanie się zaczątkiem dyskusji gremiów naukowych i być może stworzy wokół tej dyskusji środowisko specjalistów. 
ARTYKUŁY - DYSKUSJE - ESEJE

Marek J. Malinowski Bezpieczeństwo we współczesnym świecie. Istota zjawiska i jego uwarunkowania (refleksje osobiste)

Konrad Hennig Bezpieczeństwo egzystencjalne społeczeństw Zachodu wobec współczesnego sporu epistemologicznego

Artur Niedźwiedzki (Nie)Bezpieczna Europa po Brexicie?

Waldemar Mańkowski Bezpieczeństwo biologiczne populacji. Zdrowie publiczne a Państwowa Inspekcja Sanitarna jako najważniejsza instytucja sfery zdrowia publicznego

Piotr Ogrodowczyk „Środki aktywne” - skuteczne działania rosyjskich służb specjalnych

Agnieszka Stanecka Veiling and Unveiling Fears in Leila Aboulela's Minaret

Łukasz Zwoliński Znaczenie logistyki w zarządzaniu kryzysowym MISCELLANEA

Ilona Balcerczyk Society in the theory of Karl Popper

Sabrina P. Ramet Muzyka rockowa a polityka w Polsce: poetyka protestu i oporu w tekstach utworów rockowych

Kamila Lasocińska Kształtowanie twórczej codzienności. Warsztat autobiograficzny jako metoda wspomagania kreatywności dorosłych

Mirosław Mielczarek Przygotowanie do samodzielności życiowej usamodzielnianych wychowanków placówek opiekuńczo-wychowawczych

Elżbieta Woźnicka Niesłyszący nauczyciel w systemie edukacji - szanse i ograniczenia Łukasz Zaorski-Sikora Kreatywna edukacja. Dobre praktyki PRACE STUDENTÓW

Izabela Maruszewska Znaczenie funkcji sołtysa we współczesnej Polsce

Adam Fik Islamskie organizacje terrorystyczne na przykładzie Al-Kaidy i Państwa Islamskiego

Sebastian Szulc Nacjonalizm w przeszłości i czasach obecnych w Europie RECENZJE

Edyta Pietrzak Aldona Wiktorska-Święcka, Monika Klimowicz, Małgorzata Michalewska-Pawlak Innowacje we współzarządzaniu rozwojem regionalnym. Praktyka instytucjonalna w wybranych regionach $w$ Polsce

Edyta Pietrzak Inga B. Kuźma, Łucja Lange (red.) Mieszkanie i dom jako nieoczywistość kulturowo-społeczna

Edyta Pietrzak Joanna Sośnicka (red.) Inżynier z duszq̨ humanisty 